DOE/ID-10474

September 1995

Revision 2

\title{
Idaho National Engineering Laboratory (INEL) Environmental Restoration (ER) Program Baseline Safety Analysis File (BSAF)
}

RECEIVED

NOV 211995

OSTI

\section{Idaho National Engineering Laboratory}

U.S. Department of Energy $\cdot /$ daho Operations Office 


\title{
Idaho National Engineering Laboratory (INEL) Environmental Restoration (ER) Program Baseline Safety Analysis File (BSAF)
}

\author{
REVISION 2
}

EFFECTIVE DATE:

APPROVALS:

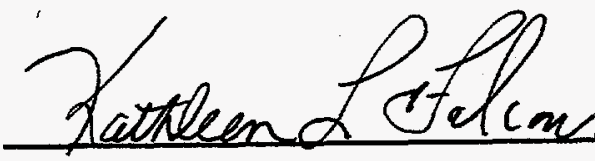

K. L. Falconer, Manager

Date

Environmental Restoration Directorate

\section{DISCLAIMER}

This report was prepared as an account of work sponsored by an agency of the United States Government. Neither the United States Government nor any agency thereof, nor any of their employees, makes any warranty, express or implied, or assumes any legal liability or responsibility for the accuracy, completeness, or usefulness of any information, apparatus, product, or process disclosed, or represents that its use would not infringe privately owned rights. Reference herein to any specific commercial product, process, or service by trade name, trademark, manufacturer, or othervise does not necessarily constitute or imply its endorsement, recommendation, or favoring by the United States Government or any agency thereof. The views and opinions of authors expressed herein do not necessarily state or reflect those of the United States Government or any agency thereof.

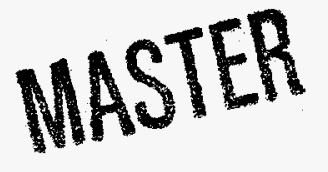




\section{DISCLAIMER}

Portions of this document may be illegible in electronic image products. Images are produced from the best available original document. 


\title{
Idaho National Engineering Laboratory (INEL) Environmental Restoration (ER) Program Baseline Safety Analysis File (BSAF)
}

Published September 1995

\author{
Idaho National Engineering Laboratory \\ Lockheed Idaho Technologies Company \\ Idaho Falls, Idaho 83415
}




\section{ABSTRACT}

The Baseline Safety Analysis File (BSAF) is a facility safety reference document for the Idaho National Engineering Laboratory (INEL) environmental restoration activities.

The BSAF contains information and guidance for safety analysis documentation required by the U.S. Department of Energy (DOE) for environmental restoration (ER) activities, including:

- Characterization of potentially contaminated sites (not covered by INEL-95-0088, Auditable Safety Analysis for Environment Restoration Activities at the INEL, June 1995)

- Remedial investigations to identify and remedial actions to clean up existing and potential releases from inactive waste sites

- Decontamination and dismantlement of surplus facilities.

The information is INEL-specific and is in the format required by DOE-EM-STD-3009-94, Preparation Guide for U.S. Department of Energy Nonreactor Nuclear Facility Safety Analysis Reports. An author of safety analysis documentation need only write information concerning that activity and refer to BSAF for further information or copy applicable chapters and sections.

The information and guidance provided are suitable for:

- $\quad$ Nuclear facilities (DOE Order 5480.23, Nuclear Safety Analysis Reports) with hazards that meet the Category 3 threshold (DOE-STD-1027-92, Hazard Categorization and Accident Analysis Techniques for Compliance with DOE Order 5480.23, Nuclear Safety Analysis Reports)

- Radiological facilities (DOE-EM-STD-5502-94, Hazard Baseline Documentation)

- Nonnuclear facilities (DOE-EM-STD-5502-94) that are classified as "low" hazard facilities (DOE Order 5481.1B, Safety Analysis and Review System).

Additionally, the BSAF could be used as an information source for Health and Safety Plans and for Safety Analysis Reports (SARs) for nuclear facilities with hazards equal to or greater than the Category 2 thresholds, or for nonnuclear facilities with "moderate" or "high" hazard classifications.

The BSAF was prepared for DOE by Lockheed Idaho Technologies Company. It is organized into the 17-chapter format recommended in DOE-STD-3009-94, "Preparation Guide for U.S. Department of Energy Nonreactor Nuclear Facility Safety Analysis Reports." This 17chapter format addresses the 21 topics required by DOE Order 5480.23, "Nuclear Safety Analysis Reports," April 1992. The BSAF contains most of the information necessary to complete a Safety Analysis Report or an auditable safety analysis. The analyst must, however, delete or supplement the provided material with data unique to a specific ER activity. 


\section{E-1. EXECUTIVE SUMMARY}

The Baseline Safety Analysis File (BSAF) contains information and guidance for safety analysis documentation required by the U.S. Department of Energy (DOE) for environmental restoration (ER) activities at the Iclaho National Engineering Laboratory (INEL). The information and guidance are suitable for:

- $\quad$ Nuclear facilities (DOE Order 5480.23, Nuclear Safety Analysis Reports) with hazards that meet the Category 3 threshold (DOE-STD-1027-92, Hazard Categorization and Accident Analysis Techniques for Compliance with DOE Order 5480.23, Nuclear Safety Analysis Reports)

- Radiological facilities (DOE-EM-STD-5502-94, Hazard Baseline Documentation)

- $\quad$ Nonnuclear facilities (DOE-EM-STD-5502-94) that are classified as "low" hazard facilities (DOE Order 5481.1B, Safety Analysis and Review System).

Additionally, the BSAF could be used as an information source for health and safety plans and for safety analysis reports (SARs) for nuclear facilities with hazards equal to or greater than the Category 2 thresholds, or for nonnuclear facilities with "moderate" or "high" hazard classifications.

\section{E-1.1 Facility Background and Mission}

The INEL was established in 1949 as the National Reactor Testing Station (NRTS) on land formerly used as a U.S. Navy weapons proving ground. The NRTS was named a national laboratory by congressional action in 1974, at which time the name was changed to the INEL. The INEL's original mission was to build, test, and operate various nuclear reactors and associated facilities. Today, the INEL is a DOE multi-program laboratory; its primary mission is to provide the nation with innovations in nuclear technologies and unique scientific and engineering capabilities in nonnucle:ar programs that provide commercialization potential or enhance the quality of the environrnent. Also, inactive waste sites and facilities are investigated and remediated, where necessary.

This section of an activity-specific SAR would present general information on the background of the facility and a statement of its current mission.

The mission of the ER program is to remediate inactive sites and facilities contaminated with radioactive, hazardous, and mixed wastes at the INEL. The INEL ER program encompasses the following activities:

- Characterization of potentially contaminated sites (not covered by INEL-95-0088, Auditable Safety Analysis for Environment Restoration Activities at the INEL, June 1995)

- Remedial investigations to identify and, where necessary, remedial actions to clean up existing and potential releases from inactive waste sites 
- Decontamination and dismantlement of surplus facilities.

\section{E-1.1.1 Remediation Activities}

In 1989, under the Comprehensive Environmental Response, Compensation, and Liability Act (CERCLA), the INEL was added to the U.S. Environmental Protection Agency's (EPA's) National Priorities List of "Superfund" sites. CERCLA is a law that regulates the cleanup of inactive waste sites containing hazardous substances, including radioactive substances. In addition, the INEL must comply with the Resource Conservation and Recovery Act (RCRA), which is administered by the State of Idaho under the authority of the Idaho Hazardous Waste Management Act. RCRA is a law regulating generation, transportation, treatment, storage, and disposal of hazardous wastes and corrective action for releases to the environment of hazardous wastes.

In compliance with CERCLA, DOE entered into a Federal Facilities Agreement and Consent Order (FFA/CO) for the INEL on December 9, 1991, with the EPA and the State of Idaho (INEL 1991). This agreement has the goal of ensuring that releases, or threatened releases, of hazardous substances at the INEL are thoroughly investigated in accordance with CERCLA's implementing regulation, the National Contingency Plan, and ensuring that appropriate response actions are undertaken and completed as necessary to protect human health and the environment.

The FFA/CO process is CERCLA-based and described in the FFA/CO action plan, which is part of the agreement (INEL 1991). Activities typically follow a phased approach: initial investigation, characterization and assessment, evaluation of remedial action alternatives, issuance of a proposed plan, a record of decision, remedial design, and remedial action. For site characterization and remedial actions required by the FFA/CO, the FFA/CO process incorporates requirements to ensure the health and safety of workers and the public and to protect the environment. These FFA/CO health and safety requirements include compliance with the following Occupational Safety and Health Administration (OSHA) regulations:

- $\quad 29$ CFR 1910.120, "Hazardous Waste Operations and Emergency Response," which specifies the requirements for preparation of a health and safety plan. A health and safety plan addresses the measures taken by the contractor to ensure that the activity will be conducted in a manner safe for workers and the surrounding community. The plan is written to identify potential site-specific hazards.

- $\quad 29$ CFR 1910.119, "Process Safety Management of Highly Hazardous Chemicals," which specifies requirements for performance of a process hazard analysis. A process hazard analysis may be required for a remedial action that involves chemicals at or above the threshold quantities specified in Appendix A of the standard.

\section{E-1.1.2 D\&D Program}

The D\&D program at the INEL addresses the following: 
- Surveillance and maintenance of surplus radioactively contaminated facilities awaiting decommissioning to protect the public and worker health and safety and to reduce potential environmental hazards

- Appropriate disposition of surplus radioactively contaminated facilities in compliance with the National Environmental Policy Act, RCRA, CERCLA, and other applicable Federal and state requirements.

D\&D projects must meet the requirements of DOE Order 5820.2A, "Radioactive Waste Management," Chapter V, "Decommissioning of Radioactively Contaminated Facilities," which establishes DOE policies and guidelines for managing, decontaminating, and decommissioning radioactively contaminated facilities.

\section{E-1.2 Facility Overview}

Because the INEL is too extensive to be cleaned as a single site, it was divided in the FFA/CO into ten Waste Area Groups (WAGs) upon which to focus environmental remediation efforts. WAGs 1 through 9 generally correspond to the surface and subsurface concerns of specific operational facilities at the INEL. WAG 10 corresponds to overall concerns associated with the Snake River Plain Aquifer and those areas outside the boundaries of the facility-specific WAGs. Although the Naval Reactor Facility (NRF) (WAG 8) and Argonne National Laboratory-West (ANL-W) (WAG 9) are included in the FFA/CO, DOE-Idaho Operations Office (DOE-ID) is not responsible for these WAGs. Therefore, WAGs 8 and 9 are not part of the INEL ER program. Table E-1 provides descriptive highlights of the 10 WAGs.

INEL D\&D activities are performed in a documented and structured manner consistent with DOE 5820.2A, Chapter V. The management approach includes a facility characterization, a decision analysis aided by a cost-risk-benefit assessment, a D\&D plan, generation of a project data file, a post-D\&D characterization, and a final report. D\&D safety documentation prepared for $D \& D$ activities includes the DOE-required safety analysis documentation covering both the inactive status of a facility awaiting D\&D and actual D\&D activities, and a health and safety plan required by 29 CFR 1910.120 .

A facility is declared "surplus" if the programmatic sponsor so designates it and no future programs are identified for the facility. Table E-2 is a list of surplus facilities at the INEL (Buckland 1993).

\section{E-1.3 Facility Hazard Classification}

Hazard classification for each ER program and D\&D activity is determined by identifying the radioactive and hazardous material inventories involved with the activity and comparing these inventories to established guidelines. The hazard classification is based on DOE Order 5480.23, "Nuclear Safety Analysis Reports," 1992; DOE Order 5481.1B, "Safety Analysis and Review System," May 19, 1987; DOE-ID Supplemental Directive 5481.1B, "Safety Analysis and Review System"; and the criteria presented in DOE-STD-1027-92, "Hazard Characterization and Accident Analysis Techniques for Compliance with DOE Order 5480.23, Nuclear Safety Analysis Reports," 
Table E-1. Descriptions of the INEL WAGs.

WAG 1 Test Area North (TAN) is subdivided into 10 operable units (OUs). Potential release sites include tanks, spills, disposal sites, and wastewater disposal systems.

WAG 2 Test Reactor Area (TRA) is subdivided into 13 OUs. Sites investigated include pits, trenches, rubble piles, ponds, cooling towers, wells, French drains, and spills.

WAG 3 Idaho Chemical Processing Plant (ICPP) is subdivided into 13 OUs. Cleanup sites include potential releases from hazardous materials stored in a tank farm and items associated with wastewater disposal systems such as sumps, ponds, and injection wells.

WAG 4 Central Facilities Area is subdivided into 13 OUs. Cleanup sites include spill sites, tanks, landfills, ponds, leach field, and pits.

WAG 5 Power Burst Facility/Auxiliary Reactor Area (PBF/ARA) is subdivided into 13 OUs. Currently, PBF is in standby mode; all ARA reactors are removed. Some underwent partial or complete decontamination.

WAG 6 Experimental Breeder Reactor/Boiling Water Reactor Experiment (BORAX) contains five OUs. Sites include old tanks, small spill, and several liquid and solid waste disposal sites.

WAG 7 Radioactive Waste Management Complex has 14 OUs primarily in subsurface disposal areas. Sites include numerous pits, trenches, and vaults where radioactive and organic wastes were placed. Large asphalt pad stores waste aboveground.

WAG $8^{2} \quad$ NRF is divided into eight OUs.

WAG $9^{\text {a }} \quad$ ANL-W is subdivided into four OUs. Sites include industrial waste pond, leach pits, and ditch associated with cooling tower.

WAG 10 Seven OUs were identified to assess the Snake River Plain Aquifer and miscellaneous waste sites on an INEL-wide basis.

a. These units are part of the FFA/CO, but are not part of the INEL ER Program. 
Table E-2. INEL surplus facilities.

\begin{tabular}{|c|c|}
\hline Location & Facility \\
\hline \multirow[t]{2}{*}{ TAN } & $\begin{array}{l}\text { Loss-of-Fluid Test Facility Ancillaries - Mobile Test } \\
\text { Assembly }\end{array}$ \\
\hline & Technical Support Facility \\
\hline \multirow[t]{3}{*}{ TRA } & Engineering Test Reactor \\
\hline & Materials Test Reactor \\
\hline & Test Train Assembly Facility \\
\hline $\begin{array}{l}\text { Army Re-entry Vehicle } \\
\text { Facility Site (ARVFS) }\end{array}$ & ARVFS \\
\hline \multirow[t]{7}{*}{ ICPP } & Service Waste Diversion Facility \\
\hline & Receipt and Storage Facility \\
\hline & Fuel Processing Building \\
\hline & Headend Processing Plant \\
\hline & High Level Waste Tank Farm \\
\hline & Stored Fuel Exterior \\
\hline & Waste Calcine Facility \\
\hline PBF/ARA & ARA I, I, III \\
\hline BORAX & BORAX-V Facility \\
\hline
\end{tabular}

and DOE-EM-STD-5502-94, "Hazard Baseline Documentation." The following information is provided to assist in classifying each activity.

Three hazard categories (Category 1, 2, and 3), defined in DOE Order 5480.23, are used to classify nuclear facilities according to the consequences of credible accidents resulting in a release of radioactive material. The BSAF covers only operations that can be classified as a Category 3 hazard (potential for only localized significant consequences) or below. A radiological material inventory for Category 3 hazards [known as threshold quantities (TQs)] is presented in Table A-1 of DOE-STD-1027-92. Activities determined to fall into a hazard Category 1, 2, or 3 require safety documentation written in accordance with requirements established in DOE Order 5480.23.

Activities that have radioactive material concentrations that fall below DOE-STD-1027-92 Category 3 values and meet or exceed reportable quantity (RQ) values listed in Table 302.4 of 40 CFR 302 Appendix B are considered radiological facilities according to DOE-EM-STD-550294 and require an auditable safety analysis (ASA). The ASA can be written using the guidelines established in the BSAF. Activities that have maximum radioactive material quantities less than 40 CFR 302 Appendix B values are considered an other industrial facility (OIF), as defined in 
DOE-EM-STD-5502-94, and would require only a health and safety plan (these plans are required for all hazardous waste activities as defined in 29 CFR 1910.120).

Activities with radioactive material inventory below 40 CFR 302, Table 302.4, Appendix B, and having hazardous chemicals, are classified as nonnuclear facilities and are governed by safety guidelines established in DOE Order 5481.1B. Hazard categories (low, medium, and high) defined in DOE Order 5481.1B and DOE-ID STD 5481.1B are used to classify nonnuclear facilities according to the consequences of credible accidents resulting in a release of hazardous material.

Activities (nuclear or nonnuclear) with hazardous material inventories at or above the 29 CFR 1910.119 TQs or threshold planning quantities (TPQ) specified in 40 CFR 355 (if the chemicals are not listed in 29 CFR 1910.119) shall incorporate process safety management principles and requirements established in 29 CFR 1910.119 into the safety documentation. Radiological facilities with hazardous material inventories at or above the 29 CFR 1910.119 TQs or TPQs shall develop safety documentation in accordance with DOE Order 5481.1B (as specified in DOE-EM-STD-5502-94). Nonnuclear facilities with hazardous material inventories at or above 29 CFR 1910.119 TQs or TPQs shall develop a safety analysis in accordance with DOE Order 5481.1B requirements. Nonnuclear activities with inventories less than 29 CFR 1910.119 TQs or TPQs and greater than or equal to RQs established in 40 CFR 302 shall develop an ASA (as specified in DOE-EM-STD-5502-94). Nonnuclear activities that have maximum chemical concentrations less than 40 CFR 302 values can be classified as OIF, unless other identified hazards are not OIF, and are controlled by applicable OSHA standards. A logic diagram and chart (Figures 1 and 2 in DOE-EM-STD-5502-94) illustrate this classification process.

ER program and $\mathrm{D} \& \mathrm{D}$ activities that involve combinations of radioactive materials or hazardous chemicals should be designated as Category 3 , radiological, high, medium, or low if the sum of the ratios of the quantities of each material to the thresholds exceeds one.

ER program activities may be subdivided into segments, provided passive features preclude bringing material together or causing harmful interaction from a common event or severe phenomenon. The overall hazard classification of an ER program activity is the highest hazard category classification of the various segments of the activity. An activity, structure, or facility segment is assigned a hazard category according to the material inventory associated with that segment. However, by segmenting the activity, the necessary and appropriate design and administrative controls will be provided commensurate with the hazard.

Documentation of the classification can be as simple as providing two tables, one for the radiological inventory and one for the hazardous material inventory, in the activity-specific SAR. These tables should identify the contaminant, the quantity, the classification limit, and the ratio.

\section{E-1.4 Safety Analysis Overview}

This section (as explained in DOE-STD-3009-94) should provide an overview of the facility operations and the results of the facility safety analysis to include:

- Description of the facility operations analyzed in the SAR or ASA 
- Summary of the significant hazards associated with the facility processes including design basis accidents

- Summary of the main preventive and mitigative features relied upon in the facility safety basis.

The hazards are identified by completing checklists. Those hazards that could result in radiological or hazardous material releases are identified and analyzed further in the SAR or ASA and would be identified in this section of the executive summary.

\section{E-1.5 Organizations}

The operating contractor for $\mathrm{ER}$ is Lockheed Idaho Technologies Company (LITCO). Within the LITCO organization, ER is a directorate in the Environmental Operations Branch. The ER directorate manager is responsible for, and has full authority over, all restoration and D\&D operations through the Buried Waste and Landfill Restoration, Groundwater Restoration, Soil Restoration, and Inactive Sites Departments. The Chemical and Radiological Risk Assessment Department provides safety analysis services, including Unreviewed Safety Question evaluations.

Functions such as technical training, occupational safety, environmental protection, radiological control, emergency preparedness, and quality assurance and oversight are matrixed to ER from the Office of the President Branch of LITCO. Program business management functions are provided by the LITCO Business Management Branch.

The remedial design/remedial action contractor is Parsons Engineering Science, Inc., which reports directly to the ER directorate manager. Training, records management, and independent audit and assessment functions are performed through subcontract by Coleman Research Corporation.

\section{E-1.6 Conclusions}

This section (as explained in DOE-STD-3009-94) should provide a brief assessment of the appropriateness of the activity or facility safety basis. As part of this summary, this section would identify any issues significant to the activity or facility safety basis recognized by the operators to require further resolution, but for which delay in documenting the safety basis is not warranted or potential budgetary considerations require DOE involvement in a decision process requiring extensive study (e.g., back fit analysis).

\section{E-1.7 Organization}

The BSAF and technical safety requirements (TSRs) reference documents were prepared using the recommendations in DOE-STD-3009-94, which provides guidance for preparation of SARs for DOE nonreactor nuclear facilities. DOE-STD-3009-94 recommends a 17-chapter format that addresses the 21 topics required by DOE Order 5480.23, "Nuclear Safety Analysis 
Reports," April 1992. The correspondence between the 21 topics required by DOE Order 5480.23 and the 17-chapter format of DOE-STD-3009-94 is indicated in Table E-3.

BSAF contains most of the information necessary to complete safety analysis documentation (SAR or ASA). The analyst must, however, delete or supplement the provided material with data unique to a specific activity. Table E-4 is a minimum list of BSAF chapters and sections where activity-specific information is necessary. 
Table E-3. Correlation of BSAF SAR chapters to DOE Order 5480.23 required topics.

\begin{tabular}{lcc}
\hline \multicolumn{1}{c}{ Subject } & BSAF chapter & $\begin{array}{c}\text { DOE Order } 5480.23 \\
\text { Topic 8.b.(3) }\end{array}$ \\
\hline Executive Summary & Unnumbered & (a) \\
Site Characteristics & 1 & (c) \\
Facility Description & 2 & (d) \\
Hazard and Accident Analysis & 3 & (e), (k) \\
Safety Structures, Systems, and Components & 4 & (d) \\
Derivations of TSRs & 5 & (p) \\
Prevention of Inadvertent Criticality & 6 & (h) \\
Radiation Protection & 7 & (I), (k) \\
Hazardous Material Protection & 8 & (j), (k) \\
Radioactive and Hazardous Waste & 9 & (g) \\
Management & & (o) \\
Initial Testing, In-Service Surveillance, and & 10 & (q) \\
Maintenance & & (m) \\
Operational Safety & 11 & (n) \\
Procedures and Training & 12 & (r) \\
Human Factors & 13 & (s) \\
Quality Assurance & 14 & (t) \\
Emergency Preparedness Program & 15 & (l) \\
Provisions for D\&D & 16 & \\
Management, Organization, and Institutional & 17 & \\
Safety Provisions & & \\
\hline
\end{tabular}


Table E-4. Information needs for activity-specific safety analyses.

\begin{tabular}{ll}
\hline Chapter/section & \\
\hline Section E.1 & Facility Background and Mission \\
Section E.3 & Facility Hazard Classification \\
Section E.4 & Safety Analysis Overview \\
Section E.6 & Safety Analysis Conclusions \\
Chapter 2 & Facility Description \\
Chapter 3 & Hazard and Accident Analysis \\
Chapter 4 & Safety Structures, Systems, and Components \\
Chapter 5 & Derivation of TSRs \\
Section 7.10 & Occupational Radiation Exposures \\
Section 8.11 & Occupational Chemical Exposures \\
Section 9.4 & Radioactive and Hazardous Waste Streams and Sources \\
Section 10.4 & In-Service Surveillance Program \\
Section 11.4 .1 & Fire Hazards \\
Chapter 13 & Human Factors \\
Section 15.3 & Scope of Emergency Preparedness \\
Chapter 16 & Provisions for D\&D \\
\hline
\end{tabular}




\section{E-1.8 References}

R. J. Buckland, D.J. Kenoyer, D.H. Preussner, (Buckland 1993), INEL D\&D Long-Range Plan, EGG-WM-10924, Rev. 9, EG\&G Idaho, Inc., October 1993 (Rev 10 to be published September 1995).

Idaho National Engineering Laboratory (INEL 1991), Federal Facility Agreement and Consent Order, and Action Plan for Implementation of the Federal Facility Agreement and Consent Order, December 4, 1991, INE:L, Idaho Falls, ID. 


\section{CONTENTS}

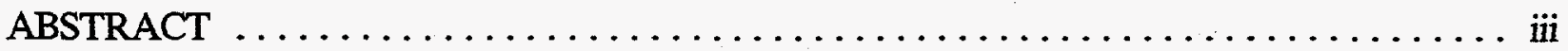

EXECUTIVE SUMMARY $\ldots \ldots \ldots \ldots \ldots \ldots \ldots \ldots \ldots \ldots \ldots \ldots \ldots \ldots \ldots \ldots \ldots$

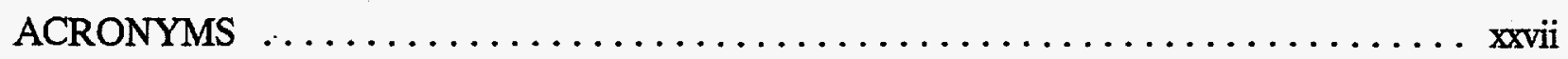

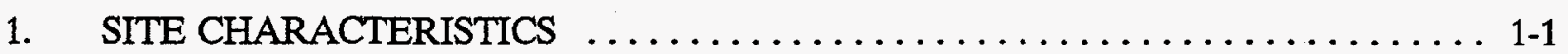

1.1 Introduction $\ldots \ldots \ldots \ldots \ldots \ldots \ldots \ldots \ldots \ldots \ldots \ldots \ldots \ldots \ldots \ldots \ldots \ldots \ldots \ldots, 1$

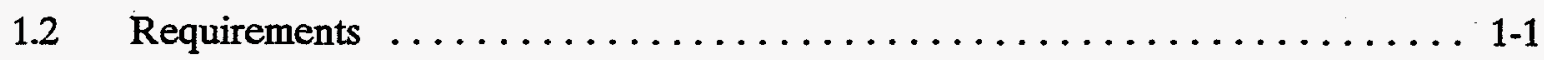

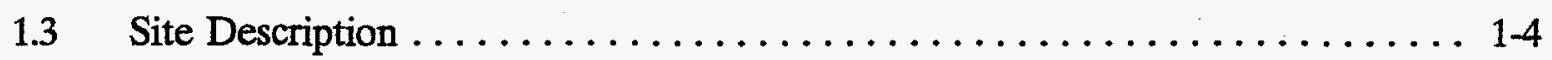

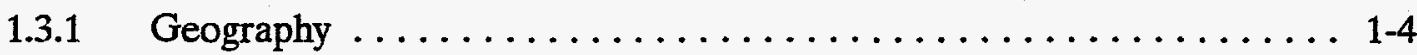

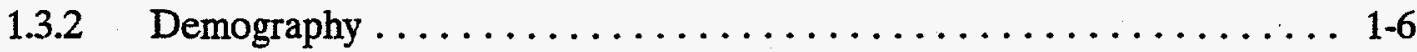

1.3.3 Regional and Local Land Use $\ldots \ldots \ldots \ldots \ldots \ldots \ldots \ldots \ldots \ldots$

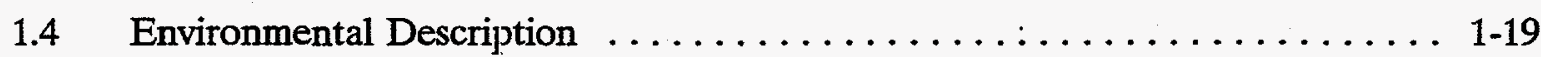

1.4.1 Meteorology .............................. 1-19

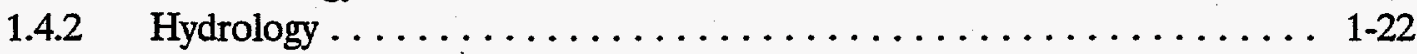

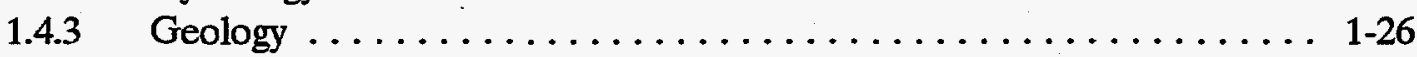

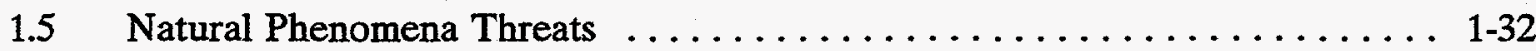

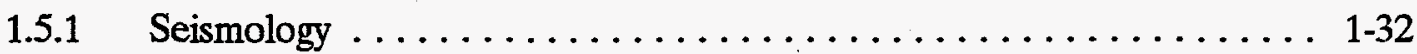

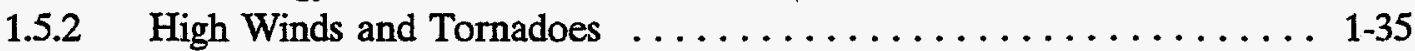

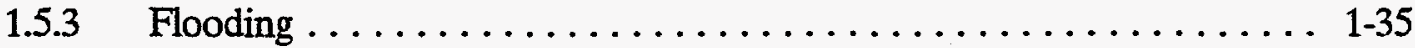

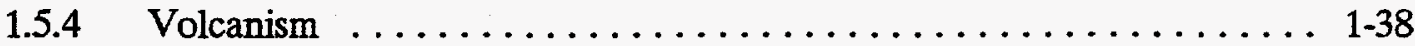

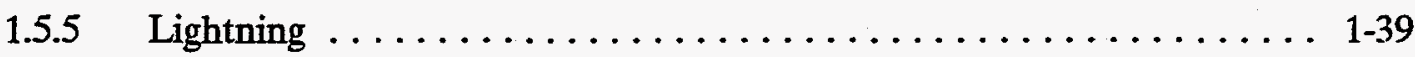

1.6 External Man-Made Threats $\ldots \ldots \ldots \ldots \ldots \ldots \ldots \ldots \ldots \ldots \ldots \ldots$ 1-40

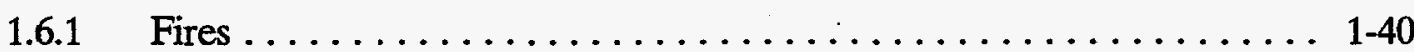

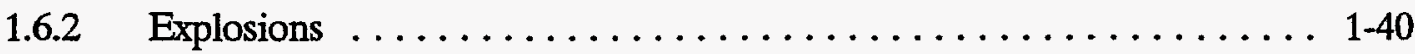

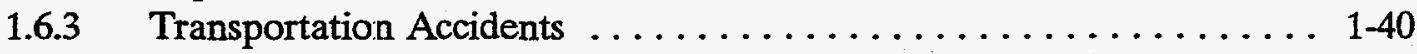

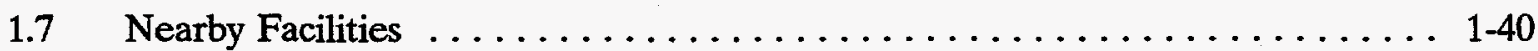

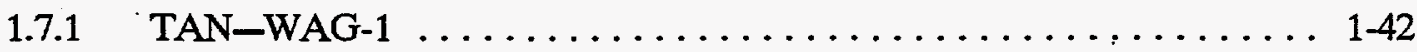

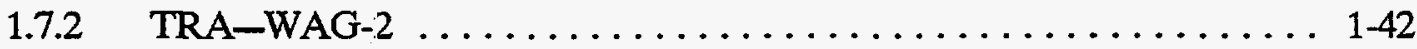

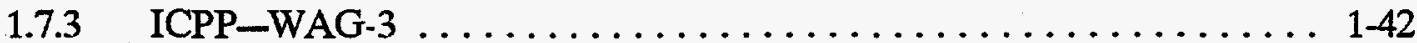

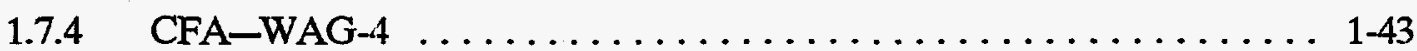

1.7.5 PBF/ARA-WAG-5 $\ldots \ldots \ldots \ldots \ldots \ldots \ldots \ldots \ldots \ldots \ldots \ldots \ldots \ldots$ 
1.7.6 EBR-1/BORAX-WAG-6 $\ldots \ldots \ldots \ldots \ldots \ldots \ldots \ldots \ldots \ldots \ldots \ldots \ldots \ldots$

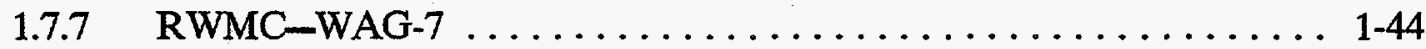

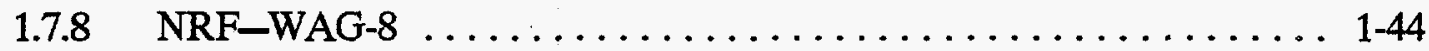

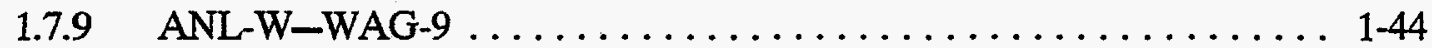

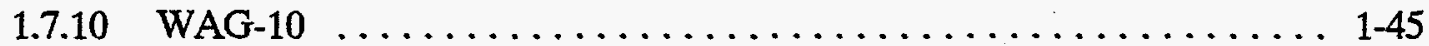

1.7.11 INEL D\&D Surplus Facilities ................... 1-45

$1.8 \quad$ Validity of Existing Environmental Analyses $\ldots \ldots \ldots \ldots \ldots \ldots \ldots \ldots . .45$

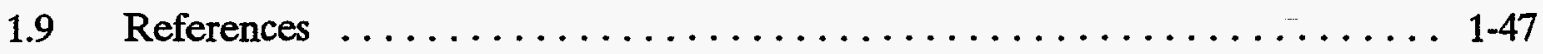

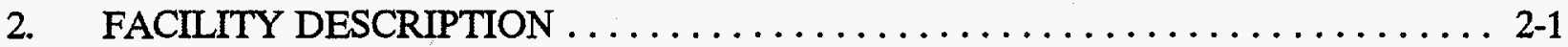

$2.1 \quad$ Introduction $\ldots \ldots \ldots \ldots \ldots \ldots \ldots \ldots \ldots \ldots \ldots \ldots \ldots \ldots \ldots \ldots \ldots \ldots, 1$

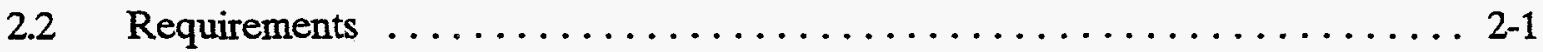

$2.3 \quad$ Facility Overview $\ldots \ldots \ldots \ldots \ldots \ldots \ldots \ldots \ldots \ldots \ldots \ldots \ldots \ldots \ldots \ldots \ldots \ldots \ldots \ldots \ldots, 2$

2.3.1 Environmental Remediation $\ldots \ldots \ldots \ldots \ldots \ldots \ldots \ldots \ldots \ldots \ldots \ldots \ldots \ldots \ldots, 2-2$

2.3.2 D\&D . . . . . . . . . . . . . . . . .

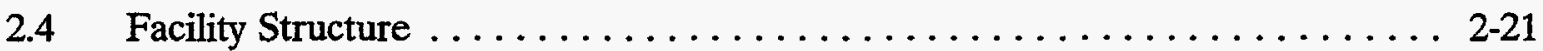

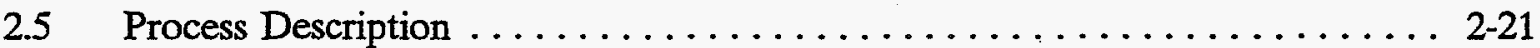

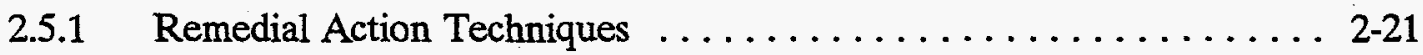

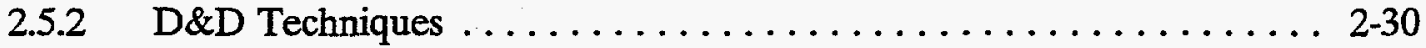

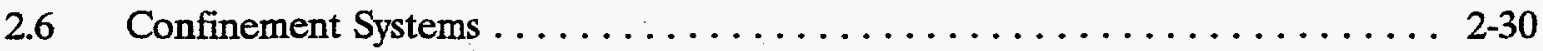

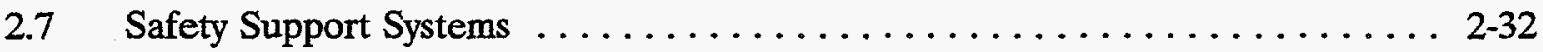

$2.8 \quad$ Utility Distribution Systems $\ldots \ldots \ldots \ldots \ldots \ldots \ldots \ldots \ldots \ldots \ldots \ldots \ldots \ldots \ldots \ldots \ldots$

$2.9 \quad$ Auxiliary Systems and Support Facilities $\ldots \ldots \ldots \ldots \ldots \ldots \ldots \ldots \ldots \ldots \ldots \ldots \ldots$

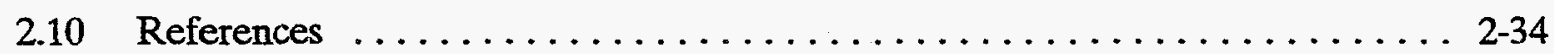

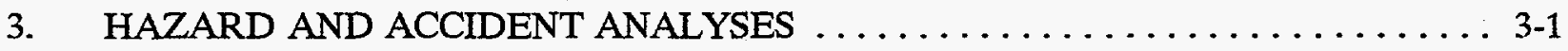

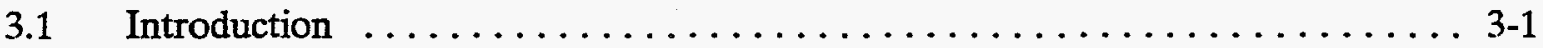

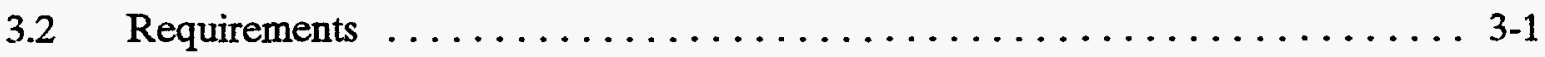

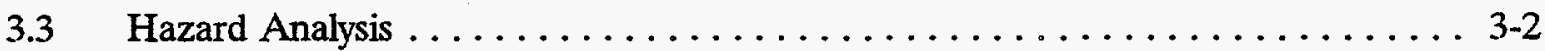


3.3.1 Methodology $\ldots \ldots \ldots \ldots \ldots \ldots \ldots \ldots \ldots \ldots \ldots \ldots \ldots \ldots \ldots \ldots \ldots \ldots, 2$

3.3.2 Hazard Analysis Results . . . . . . . . . . . . . .

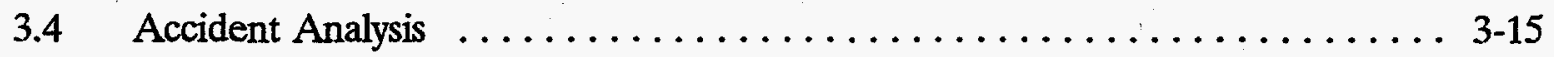

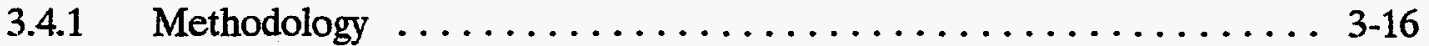

3.4.2 Bounding Accidents $\ldots \ldots \ldots \ldots \ldots \ldots \ldots \ldots \ldots \ldots \ldots \ldots \ldots, 3-20$

3.5 Example Accident Analysis $\ldots \ldots \ldots \ldots \ldots \ldots \ldots \ldots \ldots \ldots \ldots \ldots \ldots \ldots .21$

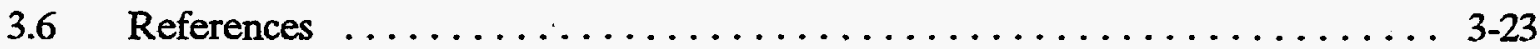

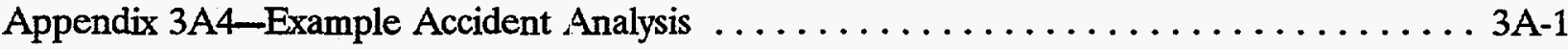

4. SAFETY STRUCTURES, SYSTEMS, AND COMPONENTS $\ldots \ldots \ldots \ldots \ldots \ldots, 4-1$

$4.1 \quad$ Introduction $\ldots \ldots \ldots \ldots \ldots \ldots \ldots \ldots \ldots \ldots \ldots \ldots \ldots \ldots, 4,1$

$4.2 \quad$ Requirements $\ldots \ldots \ldots \ldots \ldots \ldots \ldots \ldots \ldots \ldots \ldots \ldots \ldots, 4.1$

4.3 Safety-Class Systems, Structures, and Components $\ldots \ldots \ldots \ldots \ldots \ldots \ldots$ 4-1

4.4 Safety-Significant Structures, Systems, and Components $\ldots \ldots \ldots \ldots \ldots \ldots 4-2$

4.4.X Applicable Safety-significant System, Structure, or Component . . . . . 4-2

$4.5 \quad$ References $\ldots \ldots \ldots \ldots \ldots \ldots \ldots \ldots \ldots \ldots \ldots \ldots \ldots \ldots \ldots \ldots$

5. DERIVATION OF TECHNICAL SAFETY REQUIREMENTS $\ldots \ldots \ldots \ldots \ldots \ldots$. $5-1$

$5.1 \quad$ Introduction $\ldots \ldots \ldots \ldots \ldots \ldots \ldots \ldots \ldots \ldots \ldots \ldots \ldots \ldots \ldots \ldots \ldots \ldots \ldots, 1$

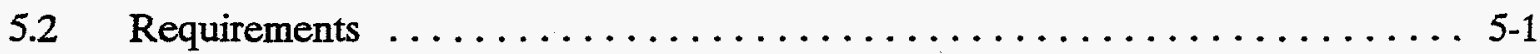

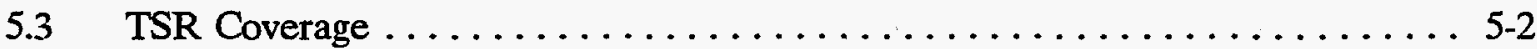

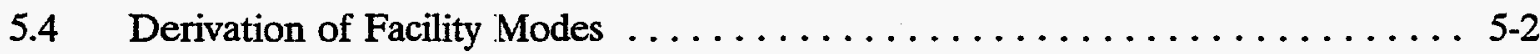

$5.5 \quad$ TSR Derivation $\ldots \ldots \ldots \ldots \ldots \ldots \ldots \ldots \ldots \ldots \ldots \ldots \ldots \ldots \ldots \ldots \ldots \ldots, 2$

5.5.1 Safety Limits, Limiting Control Settings, and Limiting Conditions for Operation .......................... $5-3$

5.5.2 Surveillance Requirements $\ldots \ldots \ldots \ldots \ldots \ldots \ldots \ldots \ldots \ldots .4$

5.5.3 Administrative Controls $\ldots \ldots \ldots \ldots \ldots \ldots \ldots \ldots \ldots \ldots . . \ldots \ldots$ 
$5.6 \quad$ Design Features $\ldots \ldots \ldots \ldots \ldots \ldots \ldots \ldots \ldots \ldots \ldots \ldots \ldots \ldots \ldots$

$5.7 \quad$ Interface with TSRs from Other Facilities $\ldots \ldots \ldots \ldots \ldots \ldots \ldots \ldots \ldots$

$5.8 \quad$ References $\ldots \ldots \ldots \ldots \ldots \ldots \ldots \ldots \ldots \ldots \ldots \ldots \ldots \ldots \ldots .7$

6. INADVERTENT CRITICALITY PROTECTION $\ldots \ldots \ldots \ldots \ldots \ldots \ldots \ldots .6$.

$6.1 \quad$ Introduction $\ldots \ldots \ldots \ldots \ldots \ldots \ldots \ldots \ldots \ldots \ldots \ldots \ldots \ldots \ldots \ldots, 1$

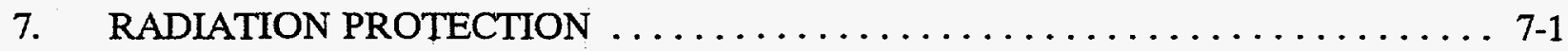

$7.1 \quad$ Introduction $\ldots \ldots \ldots \ldots \ldots \ldots \ldots \ldots \ldots \ldots \ldots \ldots \ldots \ldots, 7-1$

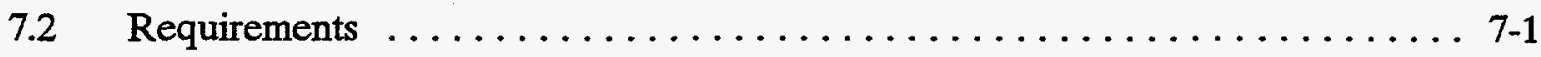

7.3 Radiation Protection Program and Organization $\ldots \ldots \ldots \ldots \ldots \ldots \ldots .7-2$

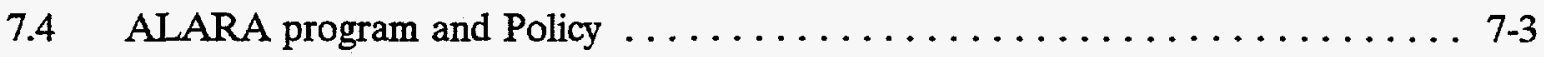

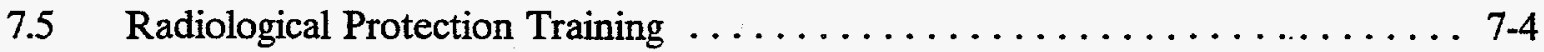

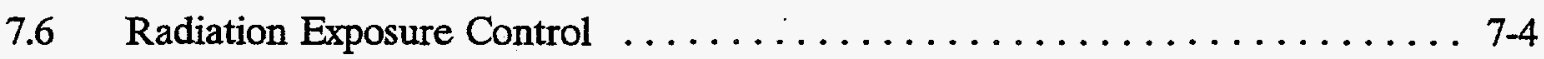

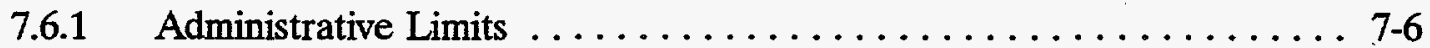

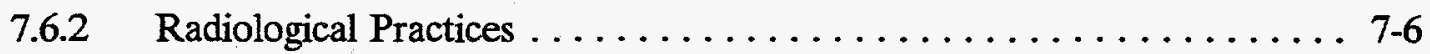

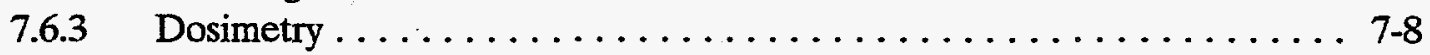

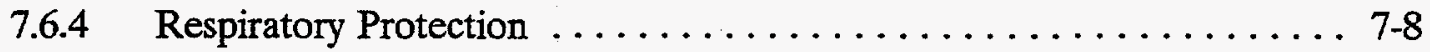

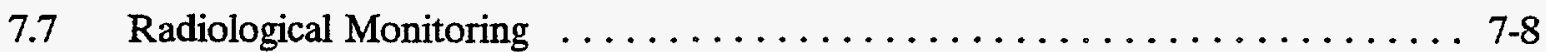

7.8 Radiological Protection Instrumentation $\ldots \ldots \ldots \ldots \ldots \ldots \ldots \ldots \ldots \ldots \ldots$

7.9 Radiological Protection Recordkeeping $\ldots \ldots \ldots \ldots \ldots \ldots \ldots \ldots \ldots \ldots \ldots \ldots$

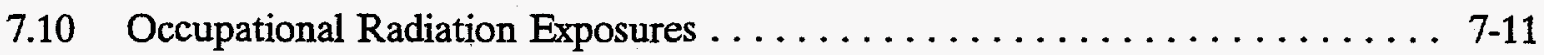

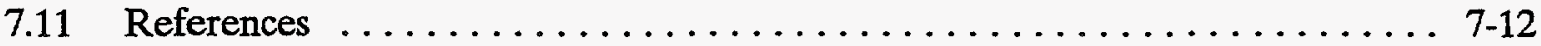

8. HAZARDOUS MATERIAL PROTECTION $\ldots \ldots \ldots \ldots \ldots \ldots \ldots \ldots \ldots$ 8-1

$8.1 \quad$ Introduction $\ldots \ldots \ldots \ldots \ldots \ldots \ldots \ldots \ldots \ldots \ldots \ldots \ldots \ldots, 8,1$

$8.2 \quad$ Requirements $\ldots \ldots \ldots \ldots \ldots \ldots \ldots \ldots \ldots \ldots \ldots \ldots \ldots . .6 .2$

8.3 Hazardous Material Protection and Organization $\ldots \ldots \ldots \ldots \ldots \ldots \ldots .6 .2$ 
8.4 ALARA Policy and Program $\ldots \ldots \ldots \ldots \ldots \ldots \ldots \ldots \ldots \ldots \ldots .2$

8.5 Hazardous Material Training $\ldots \ldots \ldots \ldots \ldots \ldots \ldots \ldots \ldots \ldots \ldots .6 \ldots \ldots$

8.6 Hazardous Material Exposure Control $\ldots \ldots \ldots \ldots \ldots \ldots \ldots \ldots \ldots . . \ldots$

8.6.1 Hazardous Material Identification Program .............. 8-3

8.6 .2 Administrative Limits $\ldots \ldots \ldots \ldots \ldots \ldots \ldots \ldots \ldots . \ldots . \ldots .4$

8.6.3 Occupational Medical Programs $\ldots \ldots \ldots \ldots \ldots \ldots \ldots \ldots \ldots . .4$

8.6.4 Respiratory Protection Program $\ldots \ldots \ldots \ldots \ldots \ldots \ldots \ldots \ldots .6 .5$

8.7 Hazardous Material Mlonitoring $\ldots \ldots \ldots \ldots \ldots \ldots \ldots \ldots \ldots \ldots .6 \ldots$

8.8 Hazardous Material Protection Instrumentation $\ldots \ldots \ldots \ldots \ldots \ldots \ldots$ 8.6

8.9 Hazardous Material Protection Recordkeeping $\ldots \ldots \ldots \ldots \ldots \ldots \ldots$ 8-7

8.10 Hazard Communication Program $\ldots \ldots \ldots \ldots \ldots \ldots \ldots \ldots \ldots . . . \ldots .7$

8.11 Occupational Chemical Exposures $\ldots \ldots \ldots \ldots \ldots \ldots \ldots \ldots \ldots \ldots$ 8-7

8.12 References $\ldots \ldots \ldots \ldots \ldots \ldots \ldots \ldots \ldots \ldots \ldots \ldots \ldots \ldots .8,8$

9. RADIOACTIVE AND HAZARDOUS MATERIAL WASTE MANAGEMENT . . . 9-1

$9.1 \quad$ Introduction $\ldots \ldots \ldots \ldots \ldots \ldots \ldots \ldots \ldots \ldots \ldots \ldots \ldots \ldots, 9.1$

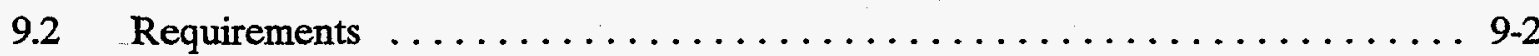

9.3 Radioactive and Hazardous Waste Management Program and Organization .... 9-2

9.4 Radioactive and Hazardous Waste Streams and Sources ............ 9-4

9.4.1 Waste Management Process $\ldots \ldots \ldots \ldots \ldots \ldots \ldots \ldots \ldots \ldots . . .4$

9.4.2 Waste Sources and Characteristics . ................... 9-4

9.4.3 Waste Handling or Treatment Systems ............... 9-10

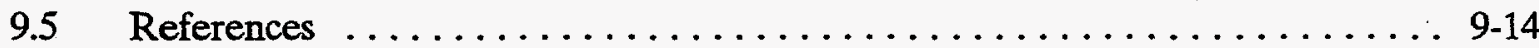

10. INITIAL TESTING, INSERVICE SURVEILLANCE, AND MAINTENANCE $\ldots \ldots$ 10-1

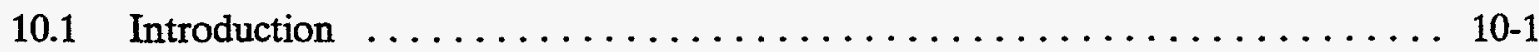

10.2 Requirements $\ldots \ldots \ldots \ldots \ldots \ldots \ldots \ldots \ldots \ldots \ldots \ldots \ldots \ldots \ldots, 10-1$

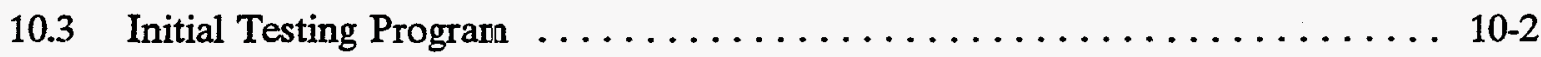


10.3.1 Initial Testing and Inspection of New Facilities $\ldots \ldots \ldots \ldots \ldots \ldots$ 10-2

10.3.2 Operational Readiness Reviews and

Readiness Assessments . . . . . . . . . . . . . . . 10-2

10.4 Inservice Surveillance Program $\ldots \ldots \ldots \ldots \ldots \ldots \ldots \ldots \ldots \ldots \ldots \ldots$

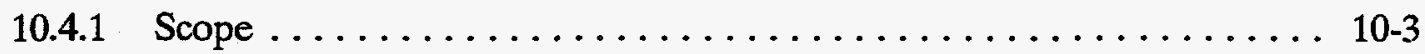

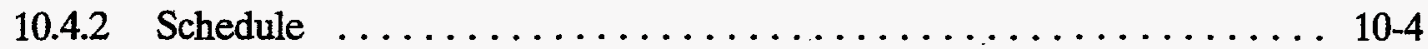

10.4.3 Compliance with Applicable Codes and Standards . . . . . . . 10-6

10.5 Maintenance Program $\ldots \ldots \ldots \ldots \ldots \ldots \ldots \ldots \ldots \ldots \ldots \ldots$

10.5.1 Compliance with DOE Order 4330.4B, "Maintenance Management Program" . . . . . . . . . . . . . . 10-6

10.5.2 Limitations on Routine Maintenance and Repair on Components Important to Safety $\ldots \ldots \ldots \ldots \ldots \ldots \ldots \ldots$ 10-7

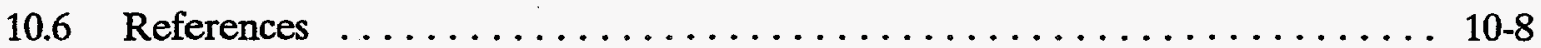

11. OPERATIONAL SAFETY $\ldots \ldots \ldots \ldots \ldots \ldots \ldots \ldots \ldots \ldots \ldots \ldots \ldots \ldots \ldots$

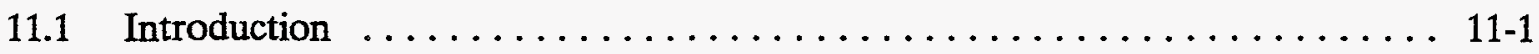

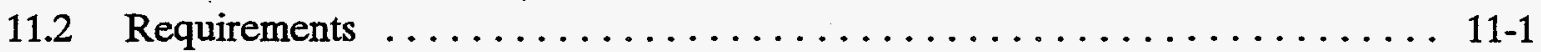

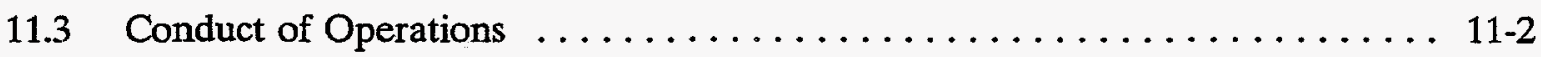

11.3.1 Shift Routines and Operating Practices . . . . . . . . . . 11-2

11.3.2 Control Area Activities . . . . . . . . . . . . . . . . . . 11-2

11.3 .3 Communications . . . . . . . . . . . . . . . . . . $11-2$

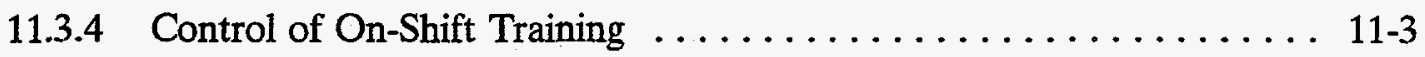

11.3.5 Control of Equipment and System Status . . . . . . . . . . 11-3

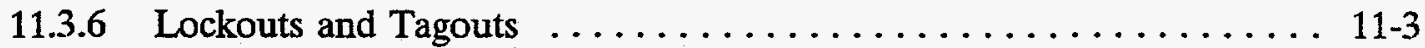

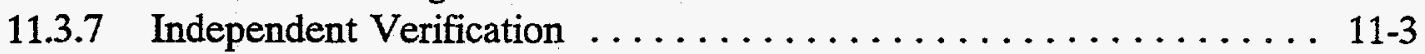

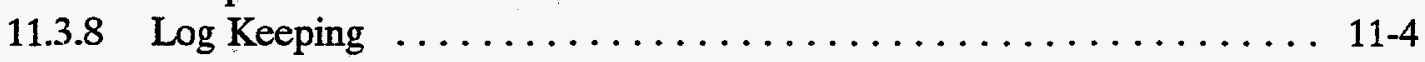

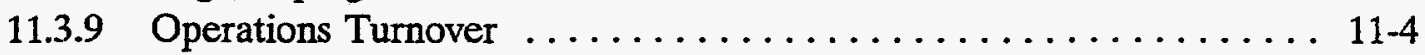

11.3.10 Operations Aspects of Facility Chemistry and

Unique Processes . . . . . . . . . . . . . . . . . . . . 11-4

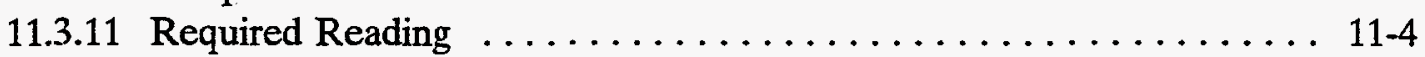

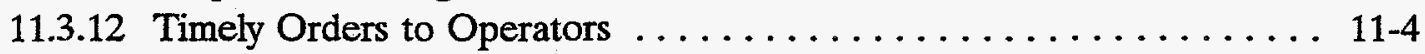

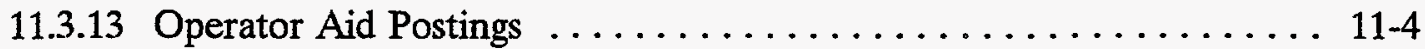

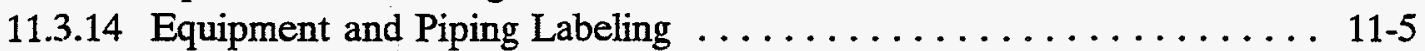

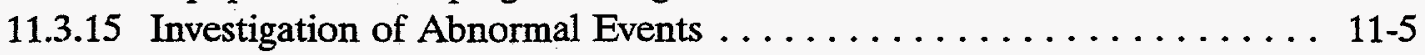




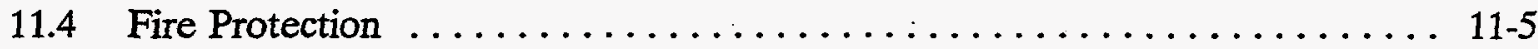

11.4.1 Fire Hazards . . . . . . . . . . . . . . . . . . . . . $11-5$

11.4.2 Fire Protection Program and Organization $\ldots \ldots \ldots \ldots \ldots \ldots \ldots \ldots \ldots \ldots$

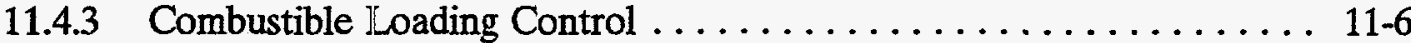

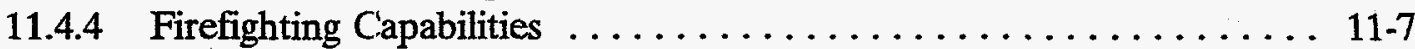

11.4.5 Firefighting Readiness Assurance $\ldots \ldots \ldots \ldots \ldots \ldots \ldots \ldots \ldots \ldots \ldots \ldots \ldots$

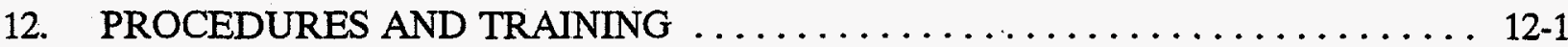

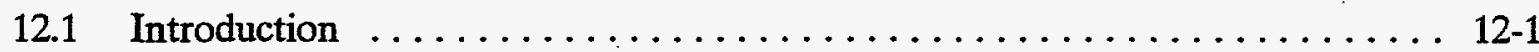

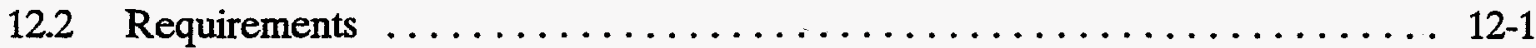

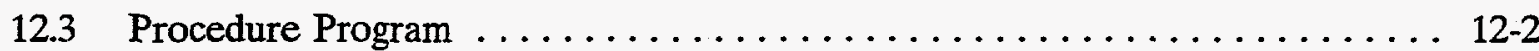

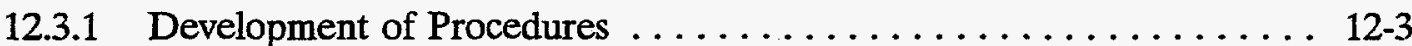

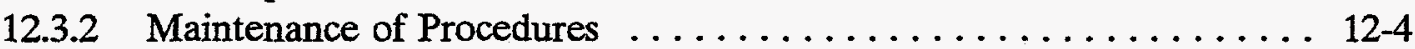

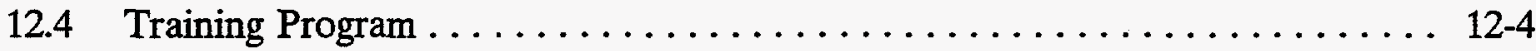

12.4.1 Development of Training . . . . . . . . . . . . . . . . . . . .

12.4.2 Maintenance of Training $\ldots \ldots \ldots \ldots \ldots \ldots \ldots \ldots \ldots \ldots \ldots \ldots \ldots \ldots \ldots \ldots \ldots, 12-8$

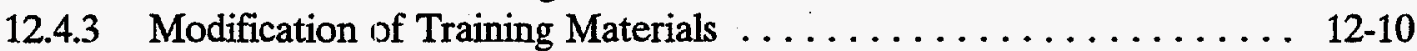

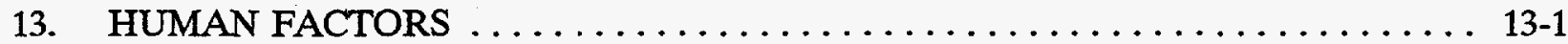

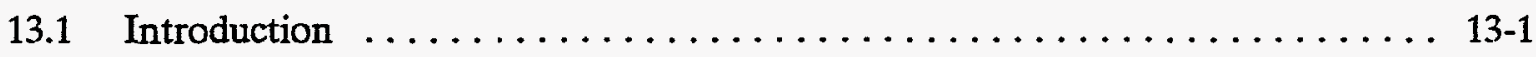

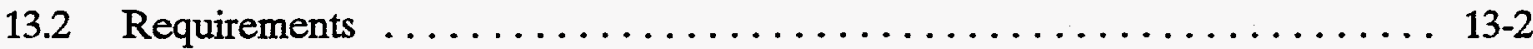

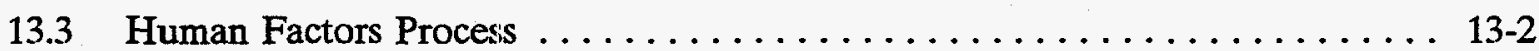

13.4 Identification of Human-Machine Interfaces $\ldots \ldots \ldots \ldots \ldots \ldots \ldots \ldots .13-4$

13.5 Optimization of Human-Machine Interfaces $\ldots \ldots \ldots \ldots \ldots \ldots \ldots \ldots \ldots \ldots$

13.5.1 Principles of Human Behavior Related to Safety ............ 13-5

13.5.2 Component A.rrangement ........................ 13-6

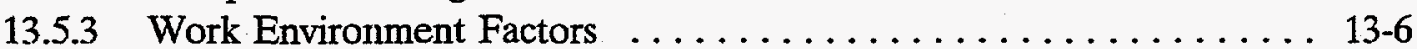

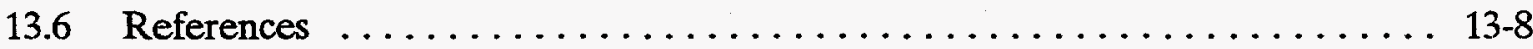

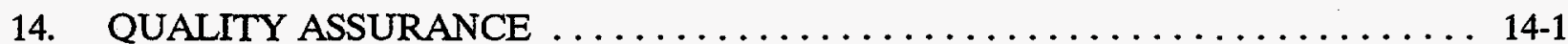

14.1 Introduction $\ldots \ldots \ldots \ldots \ldots \ldots \ldots \ldots \ldots \ldots \ldots \ldots \ldots \ldots \ldots \ldots \ldots, 14-1$

xxiii 


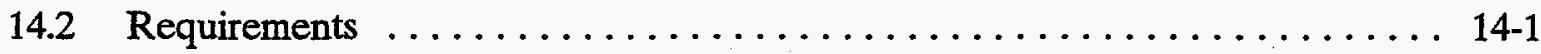

14.3 Quality Assurance Program and Organization $\ldots \ldots \ldots \ldots \ldots \ldots \ldots \ldots \ldots .14$

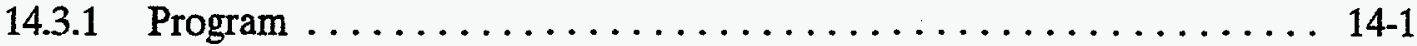

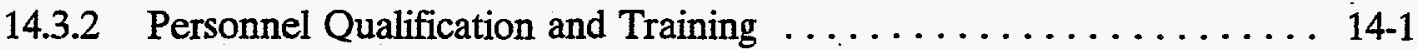

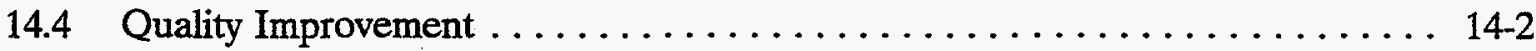

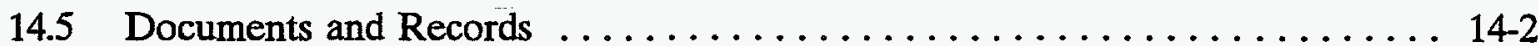

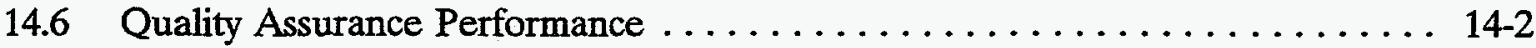

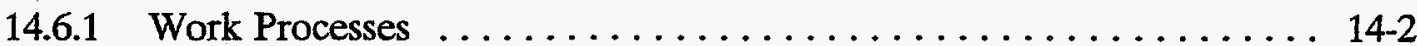

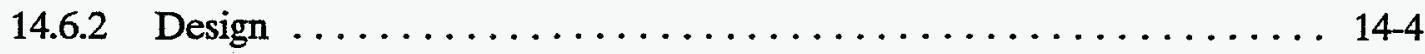

14.6.3 Procurement ............................... 14-4

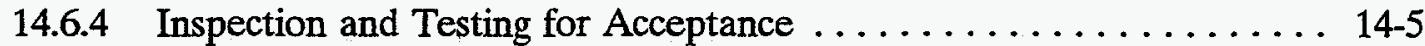

14.6.5 Assessments .............................. 14-5

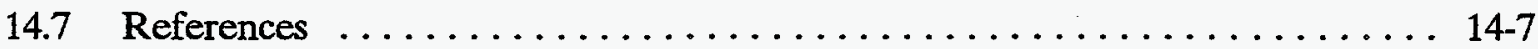

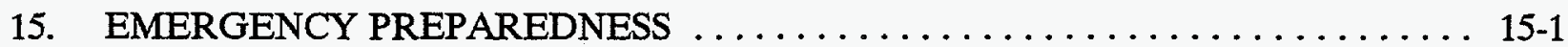

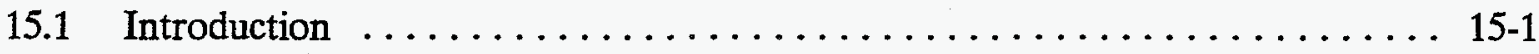

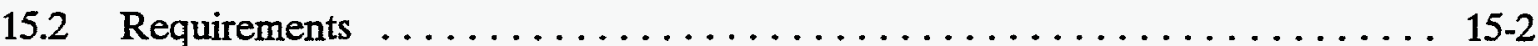

15.3 Scope of Emergency Preparedness . . . . . . . . . . . . . . . .

15.4 Emergency Preparedness Planning $\ldots \ldots \ldots \ldots \ldots \ldots \ldots \ldots \ldots \ldots \ldots \ldots \ldots \ldots \ldots \ldots, 2$

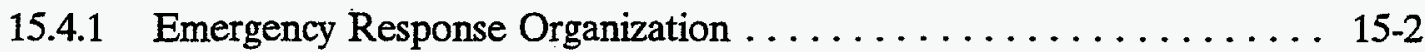

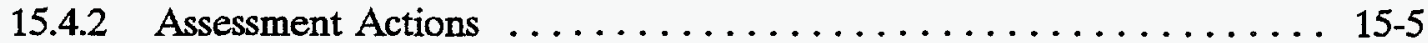

15.4.3 Notifications . . . . . . .

15.4.4 Emergency Response Equipment and Facilities ........... 15-6

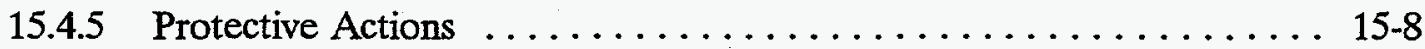

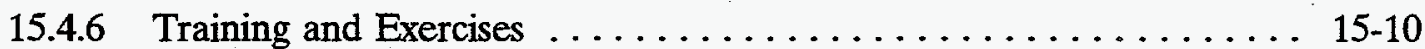

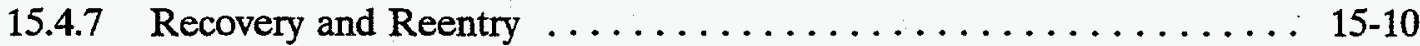

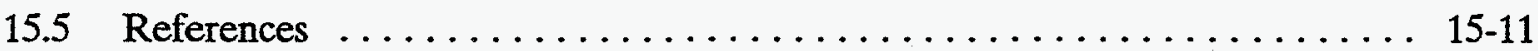

16. PROVISIONS FOR DECONTAMINATION AND DECOMMISSIONING $\ldots \ldots \ldots$ 16-1

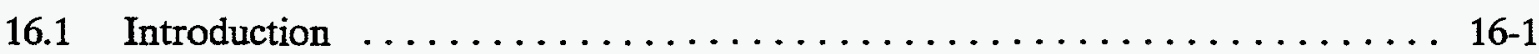

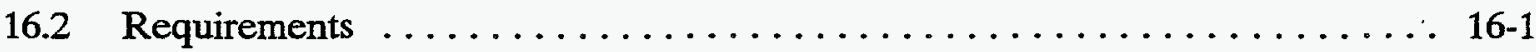

xxiv 
16.3.1 Minimizing Site and Environmental Contamination ........... 16-1

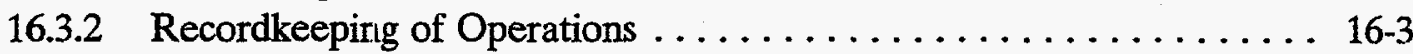

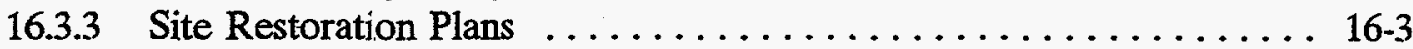

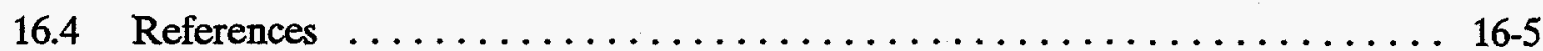

17. MANAGEMENT, ORGANIZATION, AND INSTITUTIONAL SAFETY

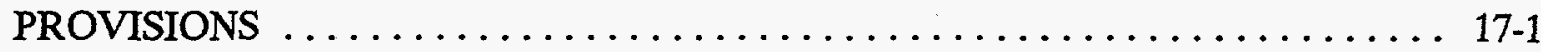

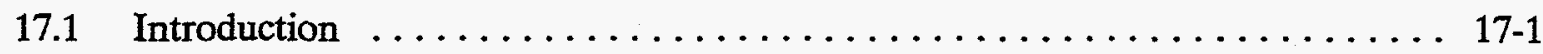

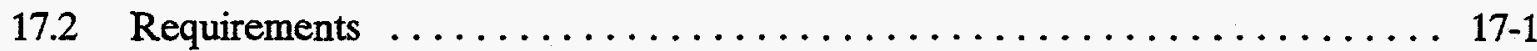

17.3 Organizational Structure, Responsibilities, and Interfaces $\ldots \ldots \ldots \ldots \ldots$ 17-2

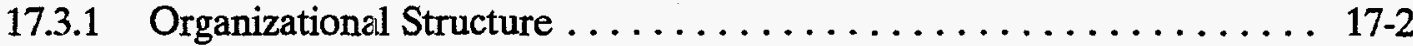

17.3.2 Organizational Responsibilities .................... 17-4

17.3.3 Staffing and Qualifications $\ldots \ldots \ldots \ldots \ldots \ldots \ldots \ldots \ldots \ldots \ldots \ldots \ldots \ldots \ldots \ldots$

17.4 Safety Management Policies and Programs $\ldots \ldots \ldots \ldots \ldots \ldots \ldots \ldots \ldots \ldots \ldots \ldots$

17.4.1 Safety Review and Performance Assessment ............ 17-6

17.4.2 Configuration and Document Control .................... 17-8

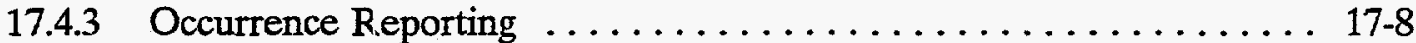

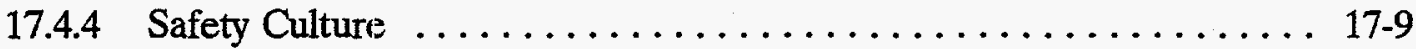

\section{FIGURES}

1-1. Map of the INEL showing surrounding mountain ranges. $\ldots \ldots \ldots \ldots \ldots \ldots \ldots$

1-2. Incorporated cities within 50 miles of the INEL $\ldots \ldots \ldots \ldots \ldots \ldots \ldots \ldots$

1-3. Topographic map of the INEL area. $\ldots \ldots \ldots \ldots \ldots \ldots \ldots \ldots \ldots \ldots$

1-4. Population within 50 miles of TAN (WAG-1) $\ldots \ldots \ldots \ldots \ldots \ldots \ldots \ldots \ldots \ldots$

1-5. Population within 50 miles of TRA $($ WAG-2) $\ldots \ldots \ldots \ldots \ldots \ldots \ldots \ldots \ldots$

1-6. Population within 50 miles of ICPP (WAG-3) $\ldots \ldots \ldots \ldots \ldots \ldots \ldots \ldots \ldots$

1-7. Population within 50 miles of CFA (WAG-4) $\ldots \ldots \ldots \ldots \ldots \ldots \ldots \ldots$

1-8. Population within 50 miles of PBF/ARA (WAG-5). $\ldots \ldots \ldots \ldots \ldots \ldots \ldots$

1-9. Population within 50 miles of RWMC (WAGs 6 and 7). $\ldots \ldots \ldots \ldots \ldots$ 


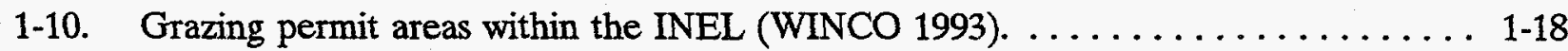

1-11. Map of Idaho showing the location of the INEL and eastern Snake

River Plain, and generalized flow lines of the Snake River Plain Aquifer. . . . . . 1-25

1-12. Location of the INEL within the context of the physiographic regions of the western United States. . . . . . . . . . . . . . . . .

1-13. Geological setting of the INEL $\ldots \ldots \ldots \ldots \ldots \ldots \ldots \ldots \ldots \ldots \ldots \ldots \ldots \ldots$

1-14. Volcanic zones in the INEL vicinity. $\ldots \ldots \ldots \ldots \ldots \ldots \ldots \ldots \ldots \ldots \ldots \ldots \ldots \ldots$

1-15. Geologic map of the INEL and adjacent area (adapted from Scott 1982;

Kuntx et al. 1992). . . . . . . . . . . . . . . . . .

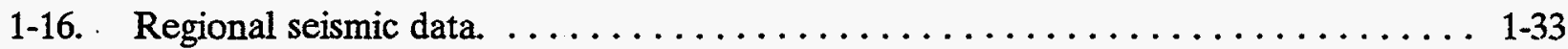

1-17. Location of surface water features on or near the INEL and inundation map for the PMF-induced overtopping failure of Mackay Dam (Koslow and Van Haaften 1986). . . . . . . . . . . . . . . . . . . . . . .

3-1. EM hazard baseline documentation process $\ldots \ldots \ldots \ldots \ldots \ldots \ldots \ldots$

17-1. ER organizational interfaces $\ldots \ldots \ldots \ldots \ldots \ldots \ldots \ldots \ldots \ldots \ldots \ldots \ldots \ldots \ldots$

\section{TABLES}

1-1. Population centers within $50 \mathrm{mi}$ of the INEL $\ldots \ldots \ldots \ldots \ldots \ldots \ldots \ldots$

1-2. Number of employees located at each INEL facility $\ldots \ldots \ldots \ldots \ldots \ldots \ldots \ldots \ldots$

1-3. Atmospheric wind stability parameters for the $10-\mathrm{m}$ height at

INEL facilities . . . . . . . . . . . . . . . . . . . . . . . . . 1-22

1-4. Distances between INEL facilities (in miles) $\ldots \ldots \ldots \ldots \ldots \ldots \ldots \ldots \ldots \ldots \ldots 1$

1-5. INEL D\&D surplus facility list $\ldots \ldots \ldots \ldots \ldots \ldots \ldots \ldots \ldots \ldots \ldots \ldots \ldots$

2-1. Facilities scheduled for D\&D and the types of waste expected to be generated.

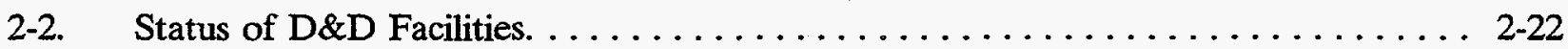

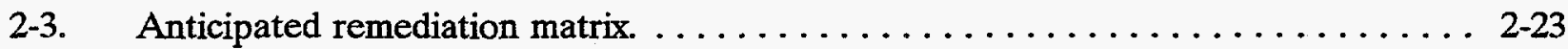

2-4. D\&D techniques. . . . . . . . . . . . . . . . 
2-5. Examples of surveillance techniques for surplus facilities. $\ldots \ldots \ldots \ldots \ldots$ 2-32

2-6. Examples of design features important to worker protection. . . . . . . . 2-33

3-1. Occupational hazard analysis checklist $\ldots \ldots \ldots \ldots \ldots \ldots \ldots \ldots \ldots \ldots \ldots \ldots$

3-2. Material and energy source hazard analysis checklist $\ldots \ldots \ldots \ldots \ldots \ldots \ldots$

3-3. Potential database events applicable to ER activities $\ldots \ldots \ldots \ldots \ldots \ldots \ldots \ldots$

3-4. Hazard classification standards $\ldots \ldots \ldots \ldots \ldots \ldots \ldots \ldots \ldots \ldots \ldots \ldots$

3-5. Example radioactive material hazard classification $\ldots \ldots \ldots \ldots \ldots \ldots \ldots \ldots \ldots$

3-6. Example hazardous material hazard classification $\ldots \ldots \ldots \ldots \ldots \ldots \ldots \ldots \ldots$. . . .

3-7. Example hazard assessment table $\ldots \ldots \ldots \ldots \ldots \ldots \ldots \ldots \ldots \ldots \ldots \ldots$

3-8. Examples of consequence analysis computer codes . . . . . . . . . . . . . 3-17

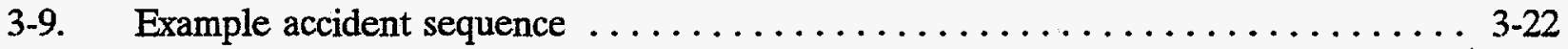

7-1. Values for radiation exposure $\ldots \ldots \ldots \ldots \ldots \ldots \ldots \ldots \ldots \ldots \ldots \ldots \ldots$

9-1. Quantities and waste types from INEL WAGS $\ldots \ldots \ldots \ldots \ldots \ldots \ldots \ldots \ldots$

9-2. Typical quantities and waste types from $D \& D$ activities $\ldots \ldots \ldots \ldots \ldots \ldots$

9-3. Waste minimization methods applicable to environmental

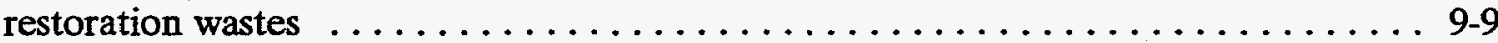

9-4. Gaseous waste treatment $\ldots \ldots \ldots \ldots \ldots \ldots \ldots \ldots \ldots \ldots \ldots \ldots \ldots \ldots \ldots$

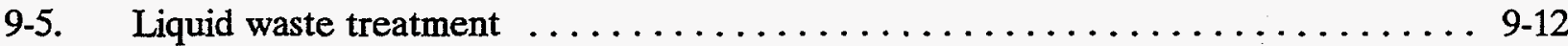

9-6. Solid waste treatment $\ldots \ldots \ldots \ldots \ldots \ldots \ldots \ldots \ldots \ldots \ldots \ldots \ldots \ldots \ldots$

10-1. Examples of scheduled surveillance actions and frequency $\ldots \ldots \ldots \ldots \ldots \ldots$

12-1. Procedures documentation summary $\ldots \ldots \ldots \ldots \ldots \ldots \ldots \ldots \ldots \ldots \ldots$

12-2. Training required under $\mathrm{OSHA} \ldots \ldots \ldots \ldots \ldots \ldots \ldots \ldots \ldots \ldots \ldots$

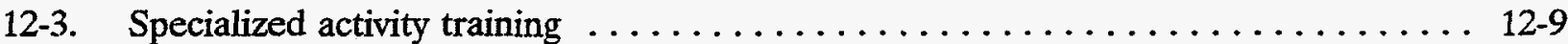


12-4. Training documentation summary $\ldots \ldots \ldots \ldots \ldots \ldots \ldots \ldots \ldots \ldots \ldots \ldots \ldots$

15-1. Applicable standards, regulations, and DOE orders $\ldots \ldots \ldots \ldots \ldots$ 


\section{ACRONYMS}

ANL-W

ANP

ARA

ARDC

ARVFS

ASA

AST

ATR

BORAX-I

BSAF

CAIRS

CDE

CDP

CEDE

CERCLA

CFA

CFR

COCA

CRC

CTF

D\&D

DBA

DOE
Argonne National Laboratory-West

U.S. Air Force Aircraft Nuclear Propulsion

Auxiliary Reactor Area

Administrative Record and Document Control

Army Re-entily Vehicle Facility Site

auditable safety analysis

accident source term

Advanced Test Reactor

Boiling Water: Reactor Experiment-1

Baseline Safety Analysis File

Computerized Accident/Incident Reporting System

committed dose equivalent

census designated place

committed effective dose equivalent

Comprehensive Environmental Response, Compensation, and Liability Act

Central Facilities Area

Code of Federal Regulations

Consent Order and Compliance Agreement

Colemen Research Corporation

Containment Test Facility

decontamination and dismantlement

design basis accident

U.S. Department of Energy 
DOE-ID

EAM

EBR-I

ECC

EDE

EM

EOC

EPA

ER

ERO

ERPG

ESH

ETR

FFA/CO

HAZWOPER

HRA

ICPP

IDLH

IET

INEL

IPA

IPDS

LCCDA

LCO
U.S. Department of Energy-Idaho Operations Office

emergency action manager

Experimental Breeder Reactor-I

Emergency Control Center

effective dose equivalent

environmental management

Emergency Operations Center

U.S. Environmental Protection Agency

environmental restoration

Emergency Response Organization

Emergency Response Planning Guideline

Environmental, Safety, and Health Program (DOE-ID)

Engineering Test Reactor

Federal Facility Agreement and Consent Order

hazardous waste operations

human reliability analysis

Idaho Chemical Processing Plant

immediately dangerous to life and health

Initial Engine Test

Idaho National Engineering Laboratory

independent performance assessment

Integrated Plant Document System

Liquid Corrosive Chemical Disposal Area

limiting conditions for operation 
LCS

LITCO

LOFT

MTR

NQA

NRF

NRTS

NSA

OIF

OMRE

ORPS

ORR

OSHA

OU

PBF

PCB

PMF

RCRA

RCT

$\mathrm{RD} / \mathrm{RA}$

RDR

RI/FS

RQ

RRWAC limiting control settings

Lockheed Idaho Technologies Company

Loss-of-Fluid Test Facility

Materials Test Reactor

Nuclear Quality Assurance

Naval Reactors Facility

National Reactor Testing Station

North Storage Area

other industrial facility

Organic Moderated Reactor Experiment

Occurrence Reporting and Processing System

Operational Readiness Review

Occupational Safety and Health Administration

operable unit

Power Burst Facility

polychlorinated biphenyl

probable maximum flood

Resource Conservation and Recovery Act

radiological control technician

remedial design/remedial action

Radiation Dosimetry and Records

remedial investigation/feasibility study

reportable quantity

Reusable Prcperty, Recyclable Materials, and Waste Acceptance Criteria 
RSAC

RWMC

RWP

SAM

SAR

SDA

SL

SL-1

SMC

SMWU

SPERT

SSC

STD

STEL

TAN

TEDE

TLV

TPQ

TQ

TRA

TRAIN

TRU

TSA

TSD radiological safety analysis computer program

Radioactive Waste Management Complex

radiological work permit

Subject Area Manual

Safety Analysis Report

Subsurface Disposal Area

safety limit

Stationary Low-Power Reactor-1

Specific Manufacturing Capability

solid waste management unit

Special Power Excursion Reactor Tests

structure, system, or component

DOE standard

short-term exposure limit

Test Area North

total effective dose equivalent

threshold limit value

threshold planning quantities

threshold quantity

Test Reactor Area

Training Records and Information Network

transuranic

Transuranic Storage Area

treatment, storage, and disposal 
Technical Support Facility

TSR technical safety requirement

TWA

time weighted -average

UOR

Unusual Occurrence Report

USQ

unreviewed safety question

UST

underground storage tank

VOC

volatile organic compound

WAG

Waste Area Group

WCB

Willow Creek: Building

WCC

Warning Comımunications Center

WERF

Waste Experimental Reduction Facility

WINCO

Westinghouse Idaho Nuclear Company

WROC

Waste Reduction Operations Complex

WRRTF

Water Reactor Research Test Facility

WSOP

WINCO Standard Operating Procedure

xxxiii 


\section{Idaho National Engineering Laboratory (INEL) Environmental Restoration (ER) Program Baseline Safety Analysis File (BSAF)}

\section{SITE CHARACTERISTICS}

\subsection{Introduction}

The Idaho National Engineering Laboratory (INEL) was established in 1949 as the National Reactor Testing Station (NRTS) on land formerly used as a United States Navy weapons proving ground. The NRTS was named a national laboratory by congressional action in 1974, at which time the name was changed to the Idaho National Engineering Laboratory (WINCO 1993). The INEL's original mission was to build, test, and operate various nuclear reactors and associated facilities. The isolated location assured maximum public safety in the then unfamiliar field of nuclear research. Today, the INEL is a United States Department of Energy (DOE) multiprogram laboratory; its primary mission is to provide the nation with innovations in nuclear technologies and unique scientific and engineering capabilities in nonnuclear programs that provide commercialization potential. or enhance the quality of the environment.

The INEL occupies about $89 \mathrm{mi}^{2}$ in southeastern Idaho (Figure 1-1). The INEL is on a high desert plain with an elevation of approximately $5,000 \mathrm{ft}$ above sea level. The site is irregularly shaped, with its longest dimension measuring $39 \mathrm{mi}$ north-to-south and $36 \mathrm{mi}$ east-towest. It encompasses portions of frve Idaho counties: Bingham, Bonneville, Butte, Clark, and Jefferson (Figure 1-2). The INEL site boundary is the effective exclusion boundary, and all activities within are controlled by DOE. Although public roads do traverse the site, arrangements in effect close roads and control access during emergencies.

This chapter was developed with existing information from current Safety Analysis Reports, site plans, INEL environmental documents, and technical literature. Additional information for sections in this chapter can be found in the reference materials used to develop the section. This chapter describes the characteristics of the environment of the INEL that influence the design, procedures, and safety of INEL operations. The standards, regulations, and DOE orders associated with characteristics of the INEL are listed in Section 1.2. Sections 1.3 and 1.4 provide site and environmental descriptions, respectively, including geography, population distribution, meteorology, hydrology, and geology for the INEL. Natural phenomena and external man-made threats that may be accident initiators are described in Sections 1.5 and 1.6. These include seismology, volcanism, flooding, lightning, high winds, fires, explosions, loss of power, and transportation accidents. Nearby facilities that could be affected by accidents occurring within INEL or whose operation could impact INEL operations are identified in Section 1.7.

\subsection{Requirements}

The following Codes of Federal Regulations (CFRs), DOE orders, and other requirements are applicable to this chapter. These requirements are implemented by INEL manuals and procedures as indicated throughout this chapter. 


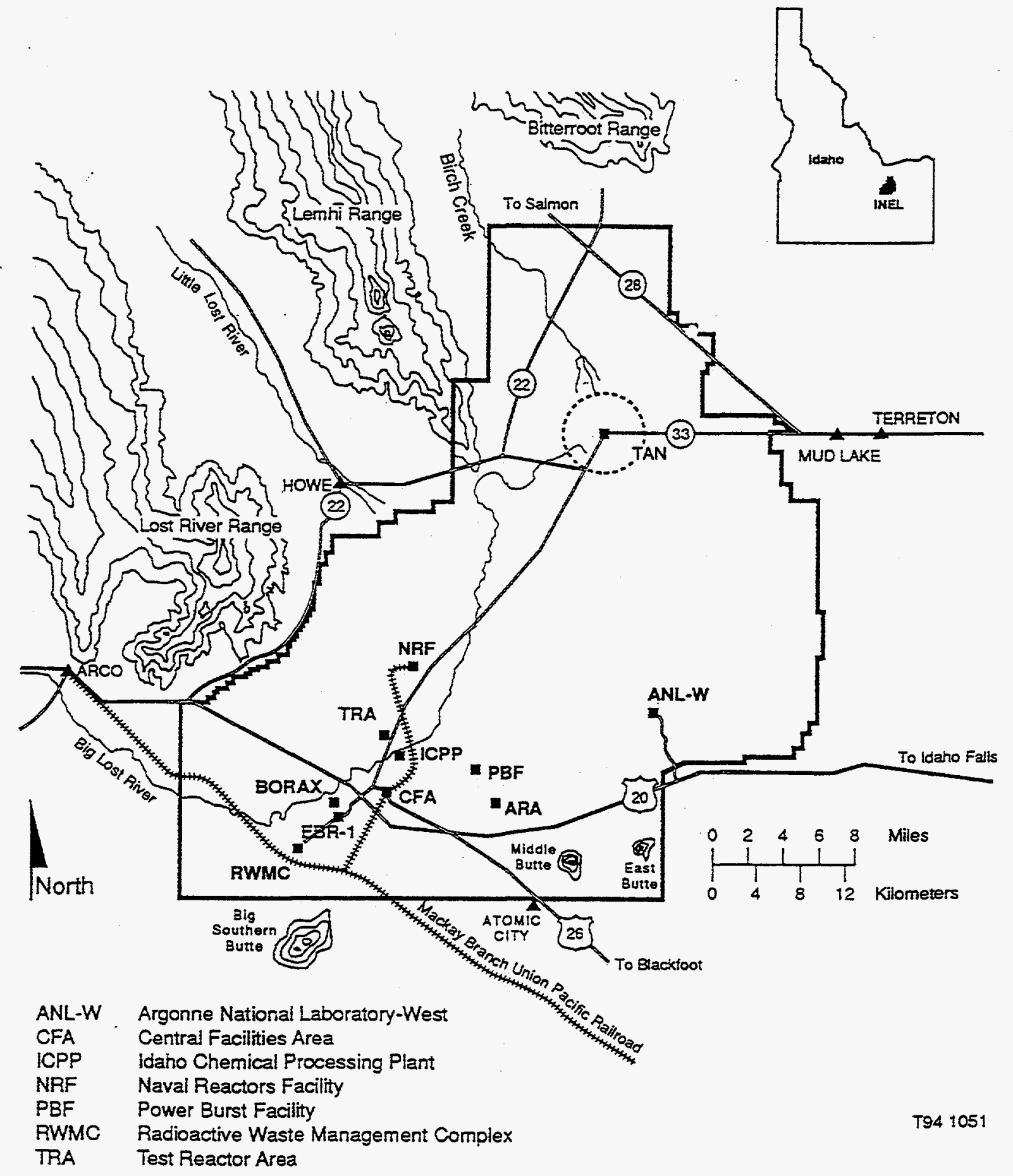

Figure 1-1. Map of the INEL showing surrounding mountain ranges. 


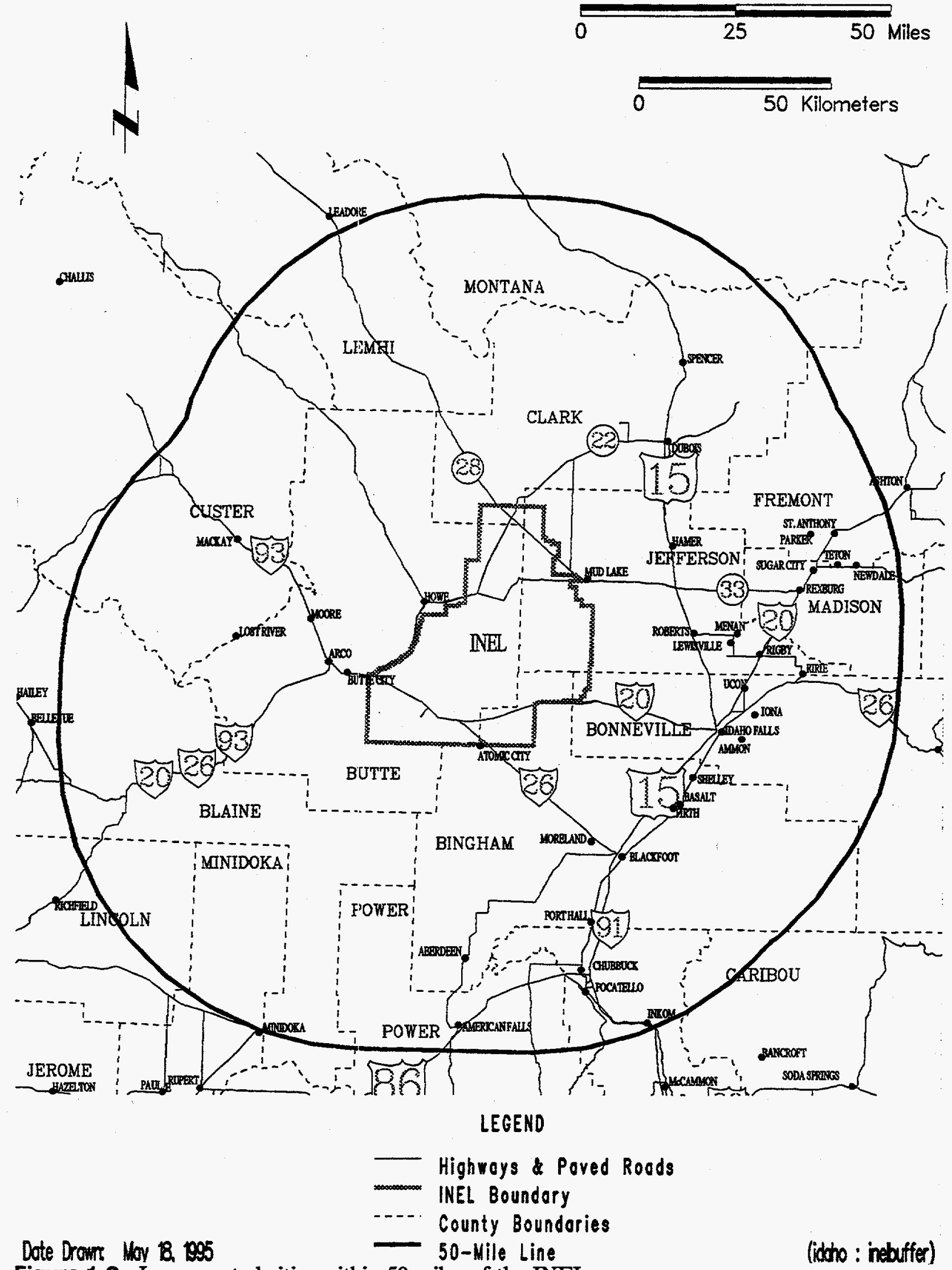

Figure 1-2. Incorporated cities within 50 miles of the INEL. 
- 40 CFR 149, "Sole Source Aquifers"

- DOE Order 5480.28, "Natural Phenomena Hazards Mitigation," January 15, 1993

- DOE Order 5500.4A, "Public Affairs Policy and Planning Requirements for Emergencies," June 8, 1992

- DOE Order 6430.1A, "General Design Criteria," April 6, 1989

- 33 United States Code (USC) 1251, Clean Water Act

- 42 USC 300, Safe Drinking Water Act

- Public Law 94-171, Census-Geographic Area; Tabulation Plan

- IDAPA S16.01.02050, Idaho State Administrative Policy on Protection of Waters of the State.

\subsection{Site Description}

The INEL is operated by DOE through management and operating contractors. The following sections describe geographic information about the INEL and its environs. Also included are present and projected permanent population information and seasonal or short-term human and domesticated animal occupation.

\subsubsection{Geography}

In this section, the geography, including topography, rivers, transportation systems, and electric power systems, are presented for the INEL region and the INEL.

1.3.1.1 Regional Geography. The INEL lies along the edge of the eastern part of the Snake River Plain in southeastern Idaho, at the foot of the Lost River, Lemhi, and Bitterroot mountain ranges. The Snake River Plain extends across southern Idaho and is a broad, low-relief, sagebrush-covered basin floored with basalt lava flows and terrestrial sediments, contrasting sharply with mountainous terrain to the north and south. The Snake River Plain is approximately 80 to $97 \mathrm{~km}$ (50 to $60 \mathrm{mi}$ ) wide and $600 \mathrm{~km}$ (375 mi) long, extending in a broad arc from the Idaho-Oregon border in the west to the Yellowstone Plateau in the east. Surface elevations on the Snake River Plain decrease gradually from over $1,980 \mathrm{~m}(6,500 \mathrm{ft})$ near the Yellowstone Plateau to approximately $640 \mathrm{~m}(2,100 \mathrm{ft})$ near the Idaho-Oregon border.

The eastern Snake River Plain covers about $10,800 \mathrm{mi}^{2}$ of southern Idaho. The land surface contains little topographic relief but for a number of buttes and volcanic scabland areas. Overall, the surface of the area slopes westwardly to about $3,200 \mathrm{ft}$ where the eastern and western parts of the Snake River Plain meet. Figure 1-3 shows the location of the INEL in Idaho, with streams and bordering mountains.

Three streams are in the vicinity of the INEL: the Big Lost River, the Little Lost River, and Birch Creek (see Figure 1-1). These waterways drain mountain watersheds to the north and northwest of the INEL. The Big Lost River flows southeast between the Lost River Range and 


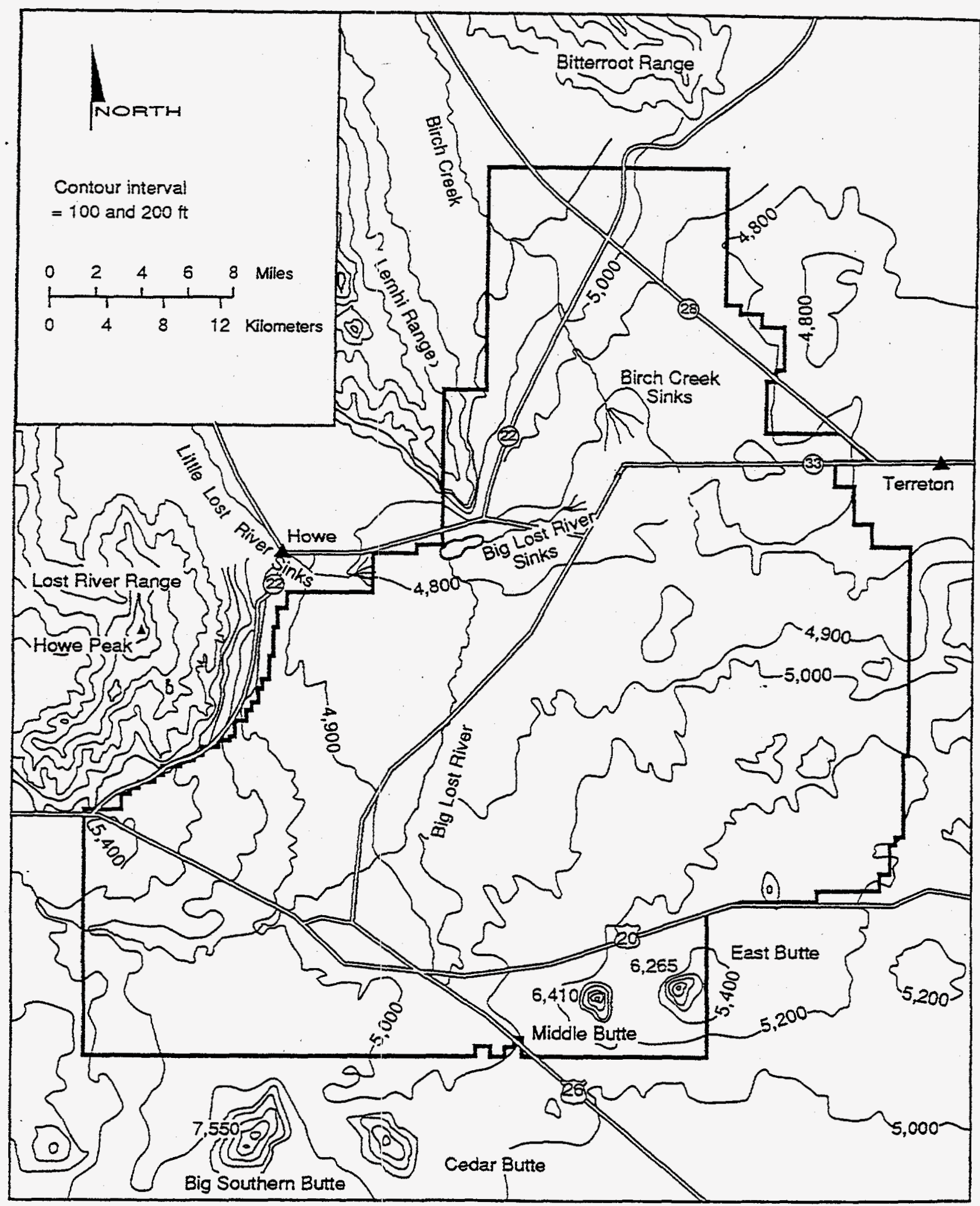

L93 0566

Figure 1-3. Topographic map of the INEL area. 
the Pioneer Mountains. The Mackay Dam, located about $48 \mathrm{~km}(30 \mathrm{mi})$ upstream of Arco, Idaho, impounds and regulates the Big Lost River flow for irrigation purposes. After being discharged from the Mackay Dam, water flows southeastward past Arco. The river flows onto the INEL at the southern part of its western boundary, curves to the northeast past the Radioactive Waste Management Complex (RWMC), and flows northeast to the Big Lost River sinks (four terminal playas). Birch Creek flows southeastward between the Lemhi and Bitterroot mountain ranges. Water in the creek is diverted northeast of the INEL for irrigation and hydropower during the summer months. In the winter months, water is returned to an artificial channel $6.5 \mathrm{~km}(4 \mathrm{mi})$ north of Test Area North (TAN), where it infiltrates into channel gravels. The Little Lost River drains the slopes of the Lemhi and Lost River mountain ranges. Little Lost River streamflow is diverted for irrigation north of Howe, Idaho, and does not normally flow onto the INEL.

1.3.1.2 INEL Geography. The INEL occupies $2,304 \mathrm{~km}^{2}\left(890 \mathrm{mi}^{2}\right)$ of semiarid plain at an average elevation of about $1,500 \mathrm{~m}(4,920 \mathrm{ft})$ above sea level. The INEL extends approximately $68 \mathrm{~km}$ (39 mi) from north to south and approximately $58 \mathrm{~km}$ (36 mi) from east to west at its broadest point. The site is $212 \mathrm{~km}$ (132 mi) southwest of Yellowstone National Park, $377 \mathrm{~km}$ (234 mi) north of Salt Lake City, Utah, and $319 \mathrm{~km}$ (198 mi) east of Boise, Idaho. Its eastern boundary is $39 \mathrm{~km}(24 \mathrm{mi})$ west of Idaho Falls, Idaho. The INEL extends into the Idaho counties of Bingham, Bonneville, Jefferson, and Clark, but lies mostly in Butte County (Kaminsky 1994).

INEL elevations range from $1,450 \mathrm{~m}(4,780 \mathrm{ft})$ at the Big Lost River sinks to about $1,650 \mathrm{~m}$ $(5,420 \mathrm{ft})$ on the northeast trending axial ridge of the plain. This broad axial ridge along the eastern edge of the INEL extends from the Craters of the Moon National Monument along the southern edge of the INEL and northeastward through the eastern INEL to the south and east of the Mud Lake area. The ridge constrains the Snake River to the southeastern edge of the Snake River Plain and causes rivers draining the mountains to the north of the plain to drain into closed basins (sinks). Four buttes are located along the axial ridge. Big Southern Butte $[2,300 \mathrm{~m}$ $(7,550 \mathrm{ft})]$, Cedar Butte [1,775 $\mathrm{m}(5,825 \mathrm{ft})]$, Middle Butte $[1,953 \mathrm{~m}(6,410 \mathrm{ft})]$, and East Butte [1,910 m $(6,265 \mathrm{ft})]$ extend 122 to $640 \mathrm{~m}(400$ to $2,100 \mathrm{ft})$ above the axial ridge. Summits of mountains surrounding the eastern Snake River Plain range to over 3,660 m (12,000 ft) (Kaminsky 1994). A topographic map of the INEL area is presented in Figure 1-3.

\subsubsection{Demography}

1.3.2.1 Offsite. All or part of 16 counties are within $50 \mathrm{mi}$ of a border of the INEL. This 16-county region has a low population density and includes 15 Idaho counties and one Montana county (see Figure 1-2). The total 1990 population for the region was 240,098 (Bureau of the Census 1992). Nearly $63 \%$ of the population in the 16-county region in 1990 resided in the two most populous counties, Bonneville and Bannock. Only six cities in the 16-county region had more than 5,000 residents in 1990 . As of 1993, the largest cities were Idaho Falls (located in Bonneville County) with 47,300 residents, and Pocatello (located in Bannock County) with 46,117 residents. These two cities represent approximately $45 \%$ of the regional population. Incorporated cities within $50 \mathrm{mi}$ of the INEL are shown in Figure 1-2. Table 1-1 shows the population centers within $50 \mathrm{mi}$ of the INEL.

1.3.2.2 Onsite. As shown in Figure 1-1, the INEL has the following nine major facility areas: TAN, Test Reactor Area (TRA), Idaho Chemical Processing Plant (ICPP), Central 
Table 1-1. Population centers within $50 \mathrm{mi}$ of the INEL.

\begin{tabular}{|c|c|c|}
\hline County & Place & Population \\
\hline \multirow[t]{5}{*}{ Bannock, ID } & Total & $\underline{60,387}$ \\
\hline & Chubbuck & 7,791 \\
\hline & Fort Hall & 1,370 \\
\hline & Inkom & 769 \\
\hline & Pocatello & $46,117^{\mathrm{a}}$ \\
\hline \multirow[t]{4}{*}{ Beaverhead, MT } & Total & $\underline{490}^{\mathrm{a}}$ \\
\hline & Dell & NA \\
\hline & Lima & $257^{a}$ \\
\hline & Monida & NA \\
\hline \multirow[t]{14}{*}{ Bingham, ID } & Total & $\underline{37,583}$ \\
\hline & Aberdeen & 1,406 \\
\hline & Atomic City & 25 \\
\hline & Basalt & 407 \\
\hline & Blackfoot & 9,646 \\
\hline & Firth & 429 \\
\hline & Fort Hall & 1,311 \\
\hline & Moreland & 8,141 \\
\hline & Pingree & NA \\
\hline & Riverside & NA \\
\hline & Shelley & 3,536 \\
\hline & Springfield & NA \\
\hline & Sterling & NA \\
\hline & Tabor & NA \\
\hline Blaine, ID & Total & $\underline{765}$ \\
\hline \multirow[t]{7}{*}{ Bonneville, ID } & Total & $\underline{73,631}$ \\
\hline & Ammon & 5,002 \\
\hline & Bone & NA \\
\hline & Idaho Falls & $47,300^{\mathrm{a}}$ \\
\hline & Iona & 1,049 \\
\hline & Lincoln & NA \\
\hline & Ucon & 895 \\
\hline \multirow[t]{6}{*}{ Butte, ID } & Total & $\underline{2.918}$ \\
\hline & Arco & 1,016 \\
\hline & Butte City & 59 \\
\hline & Darlington & NA \\
\hline & Howe & NA \\
\hline & Moore & 190 \\
\hline Caribou, ID & Total & NA \\
\hline
\end{tabular}


Table 1-1. (continued).

\begin{tabular}{|c|c|c|}
\hline County & Place & Population \\
\hline \multirow[t]{5}{*}{ Clark, ID } & Total & $\underline{762}$ \\
\hline & Dubois & 420 \\
\hline & Humphrey & NA \\
\hline & Small & NA \\
\hline & Spencer & 11 \\
\hline \multirow[t]{4}{*}{ Custer, ID } & Total & $\underline{2.590}$ \\
\hline & Leslie & NA \\
\hline & Lost River & 29 \\
\hline & Mackay & 574 \\
\hline \multirow[t]{7}{*}{ Fremont, ID } & Total & $\underline{10,118}$ \\
\hline & Ashton & 1,114 \\
\hline & Chester & NA \\
\hline & Newdale & 377 \\
\hline & Parker & 288 \\
\hline & St. Anthony & 3,010 \\
\hline & Teton & 570 \\
\hline \multirow[t]{11}{*}{ Jefferson, ID } & Total & $\underline{16,543}$ \\
\hline & Hamer & 79 \\
\hline & Heise & NA \\
\hline & Lewisville & 471 \\
\hline & Menan & 601 \\
\hline & Monteview & NA \\
\hline & Mud Lake & 179 \\
\hline & Rigby & 2,681 \\
\hline & Ririe & 596 \\
\hline & Roberts & 557 \\
\hline & Terreton & NA \\
\hline \multirow[t]{2}{*}{ Lemhi, ID } & Total & $\underline{981}$ \\
\hline & $\begin{array}{l}\text { Leadore } \\
\text { Patterson }\end{array}$ & $\begin{array}{r}74 \\
\text { NA }\end{array}$ \\
\hline \multirow[t]{2}{*}{ Lincoln, ID } & Total & $\underline{989}$ \\
\hline & Richfield & 383 \\
\hline Madison, ID & Total & $\underline{23.674}$ \\
\hline
\end{tabular}


Table 1-1. (continued).

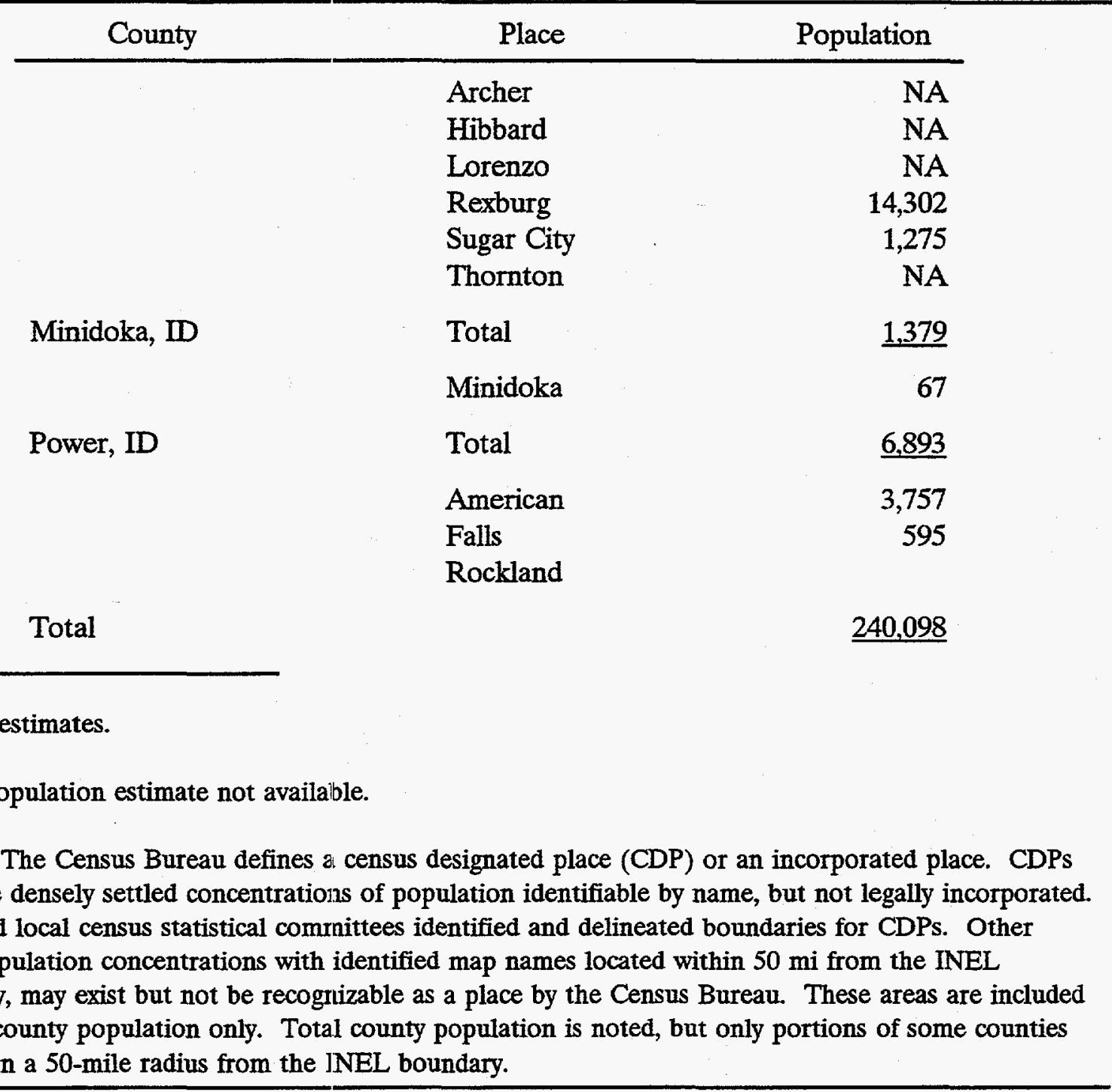


Facilities Area (CFA), Power Burst Facility/Auxiliary Reactor Area (PBF/ARA), Experimental Breeder Reactor-I/Boiling Water Reactor Experiment (EBR-I/BORAX), RWMC, Argonne National Laboratory-West (ANL-W), and Naval Reactors Facility (NRF). To focus environmental restoration efforts, each of these facilities is designated as a Waste Area Group (WAG). The tenth WAG includes the groundwater system underlying the INEL and the dispersed minor facilities and areas that represent actual and potential contaminant release sites not included in the other nine WAGs (FFA/CO 1991).

All WAGs are included in the INEL environmental restoration (ER) program with the exception of the NRF (WAG-8) and ANL-W (WAG-9). In addition, underground storage tanks and decontamination and dismantlement (D\&D) activities are part of the ER program. The size of the work force at the INEL varies with current activities. The current breakdown of the staff employed at each facility area included in the INEL ER Program is identified in Table 1-2. Population distributions within $50 \mathrm{mi}$ of WAGs 1-7 are indicated in Figures 1-4 through 1-9.

\subsubsection{Regional and Local Land Use}

The dominant land uses in the area surrounding the INEL are agricultural and open land, each type accounting for $45 \%$ of the area with the remaining $10 \%$ occupied by urban/built land (EG\&G 1990). On the INEL site, only about $2 \%$ or 11,400 acres are used for facilities and operations.

1.3.3.1 Urban/Suburban. The region adjacent to the INEL boundary is primarily public or private land for agricultural use and ranching. Therefore, population densities are low and urban and suburban land uses are spatially distant.

Table 1-2. Number of employees located at each INEL facility.

\begin{tabular}{lcc}
\multicolumn{1}{c}{ Facility } & WAG & Employees \\
\hline TAN & 1 & 346 \\
TRA & 2 & 443 \\
ICPP & 3 & 1174 \\
CFA & 4 & 862 \\
PBF/ARA & 5 & 108 \\
EBR-I/BORAX & 6 & 0 \\
RWMC & 7 & 154 \\
NRF & 8 & Not available \\
ANL-W & 9 & 860 \\
\hline
\end{tabular}




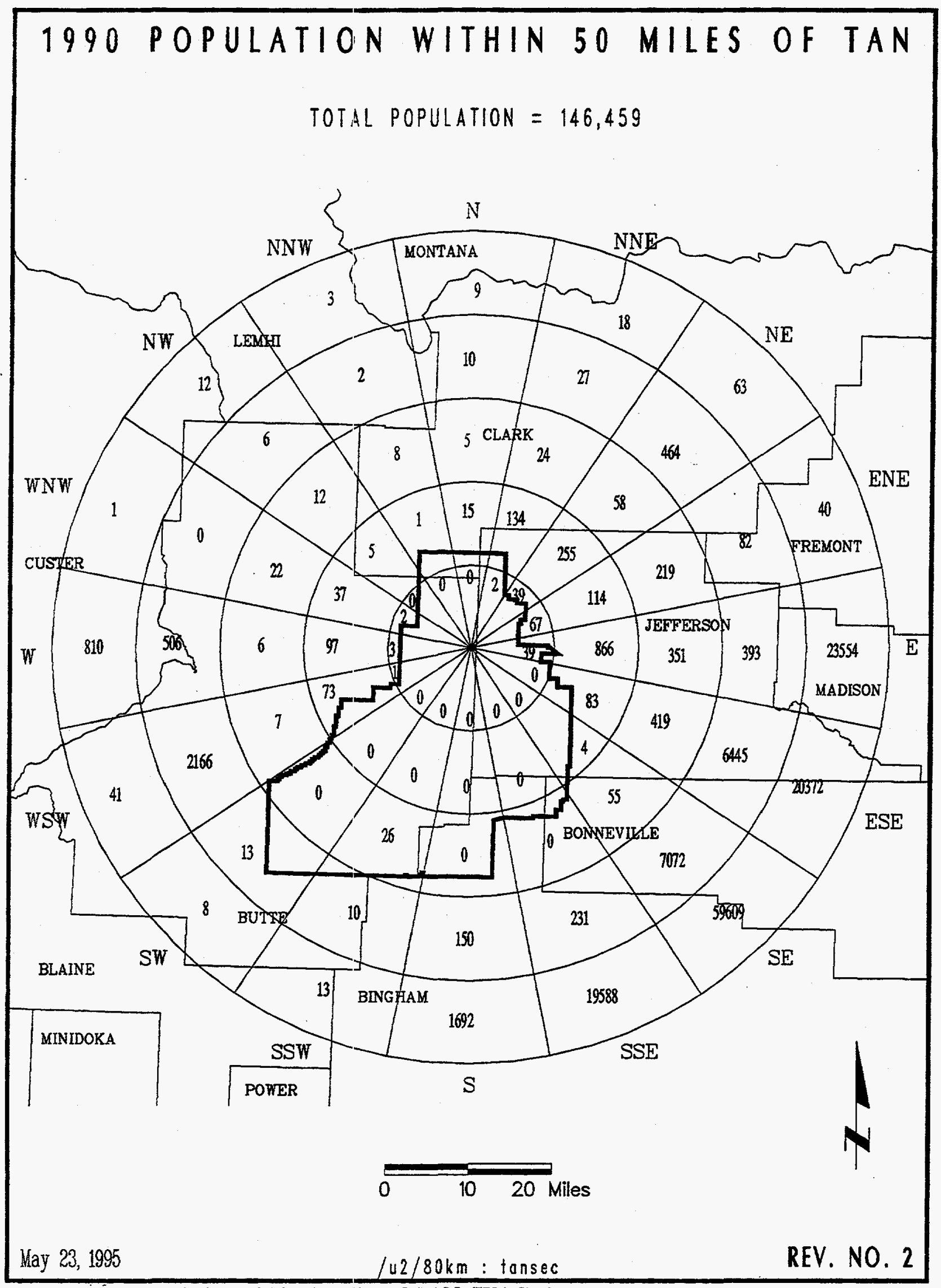

Figure 1-4. Population within 50 miles of TAN (WAG-1). 


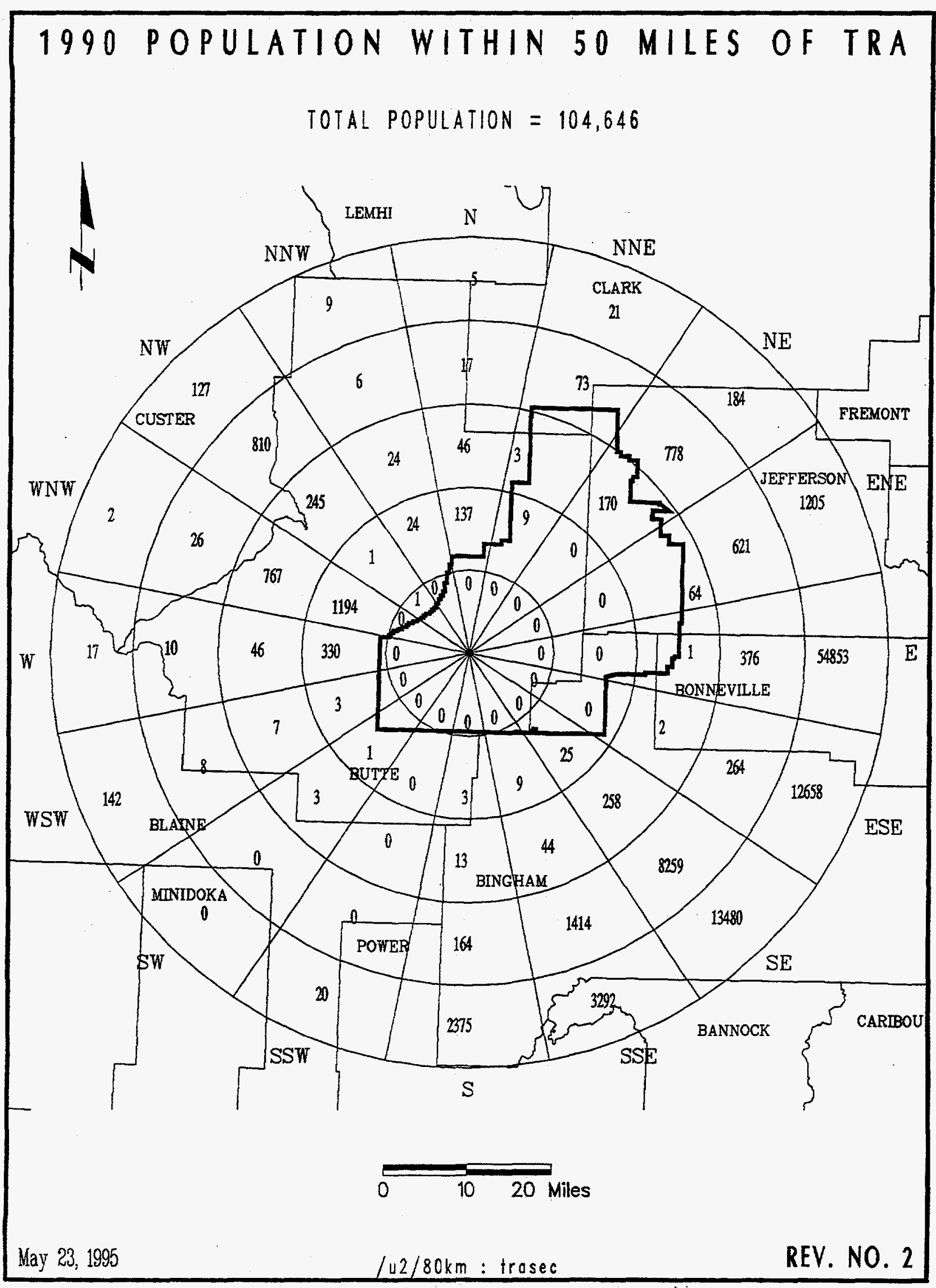

Figure 1-5. Population within 50 miles of TRA (WAG-2). 


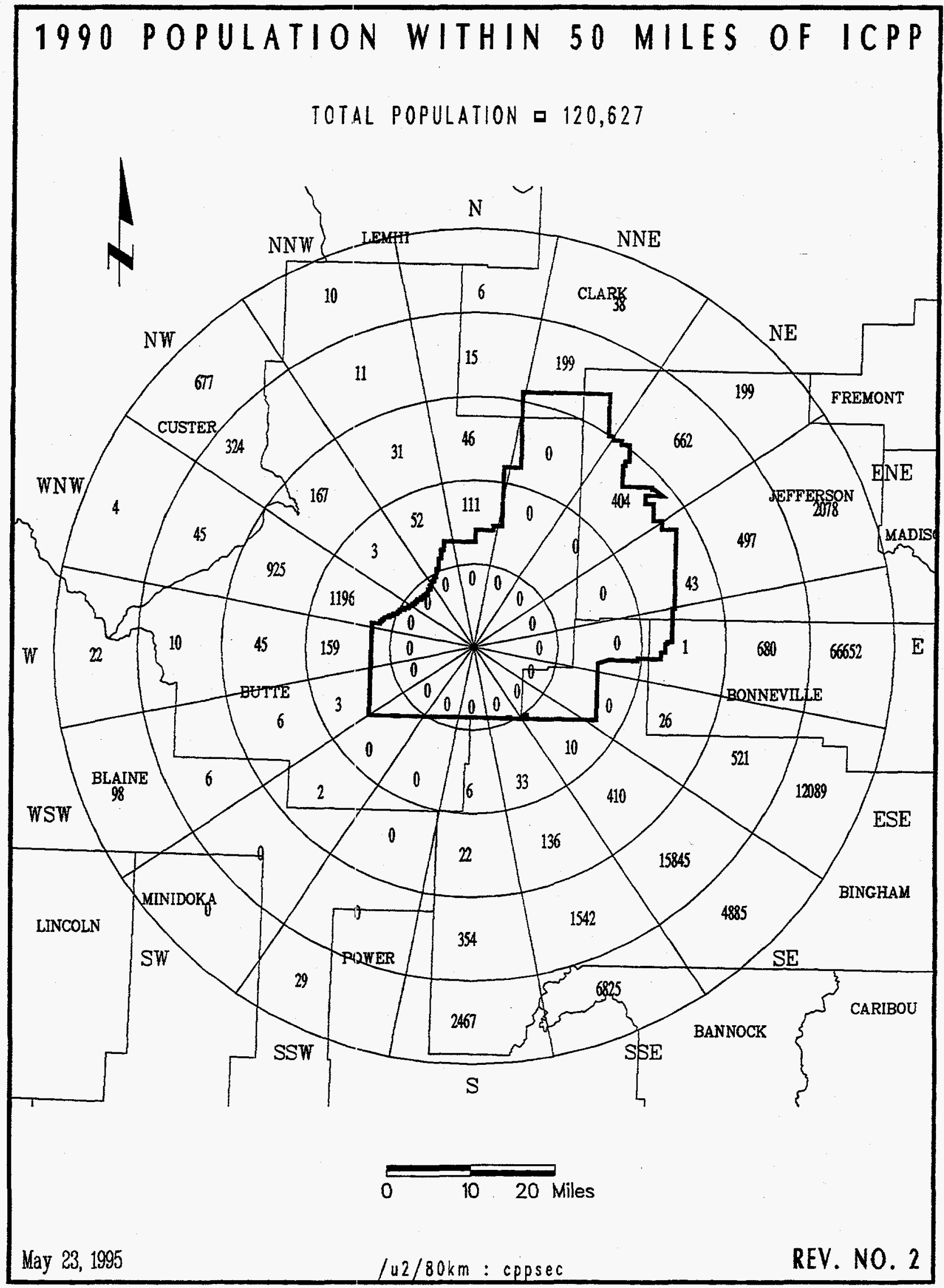

Figure 1-6. Population within 50 miles of ICPP (WAG-3). 


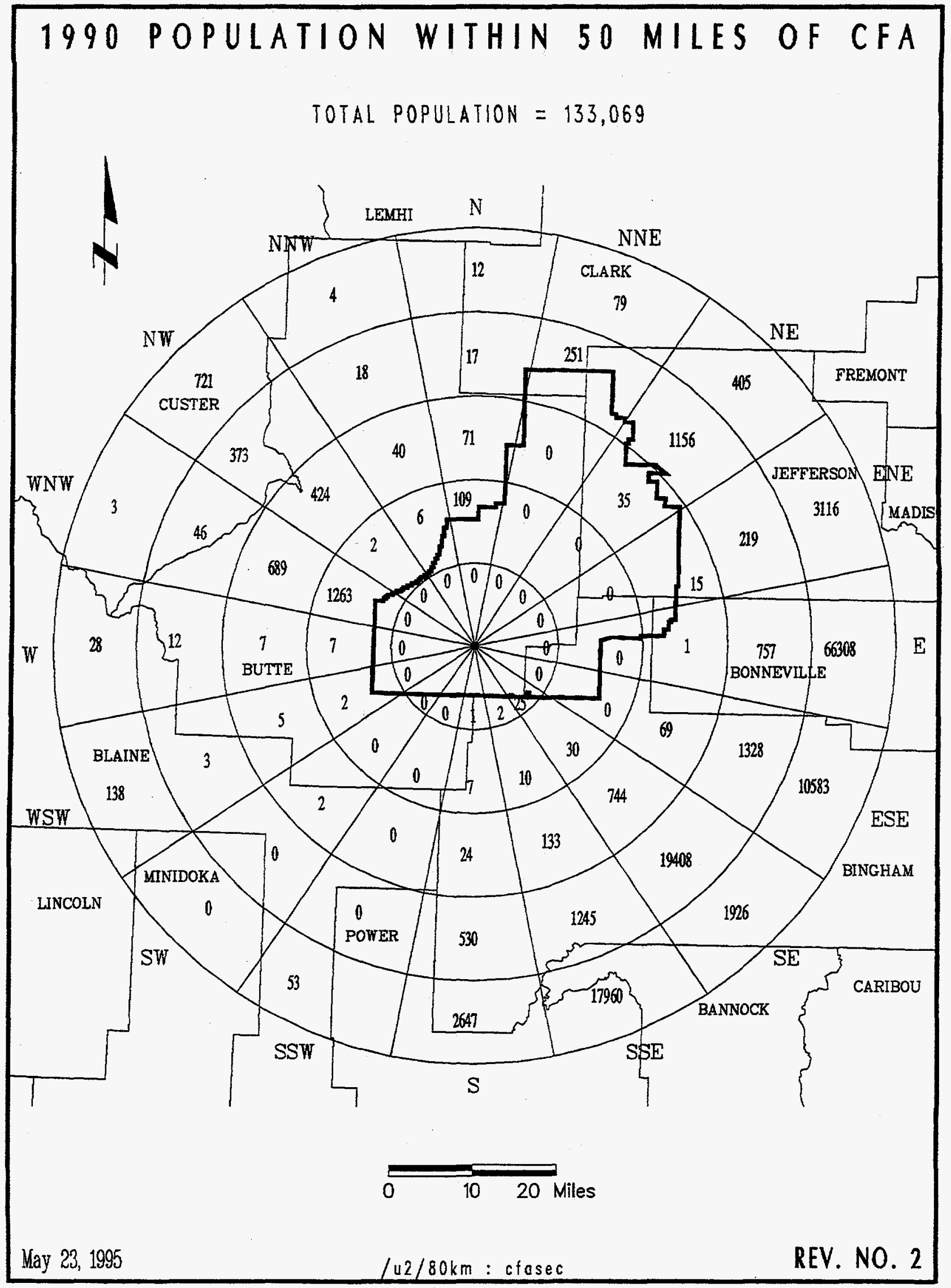

Figure 1-7. Population within 50 miles of CFA (WAG-4). 


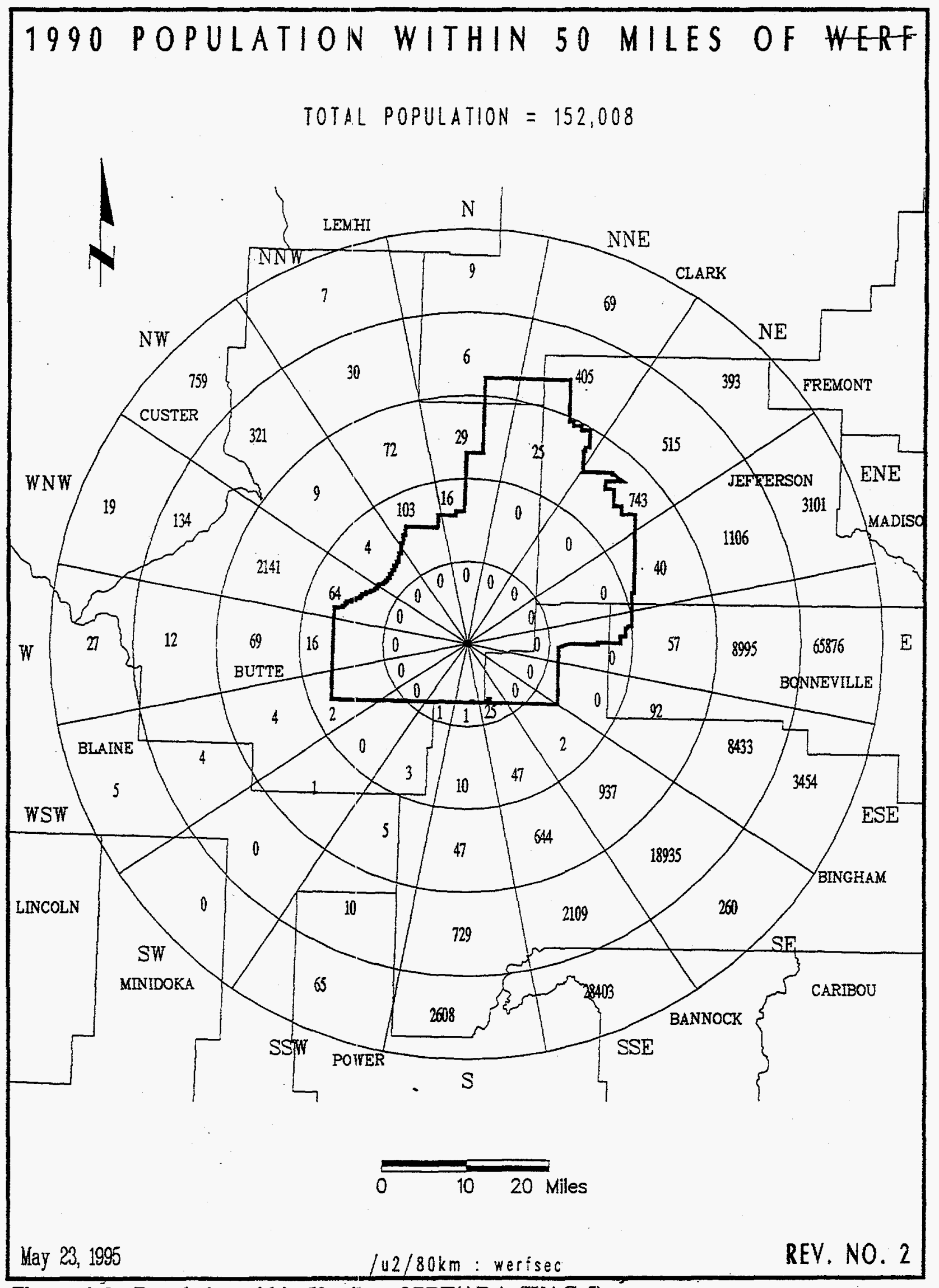

Figure 1-8. Population within 50 miles of PBF/ARA (WAG-5). 


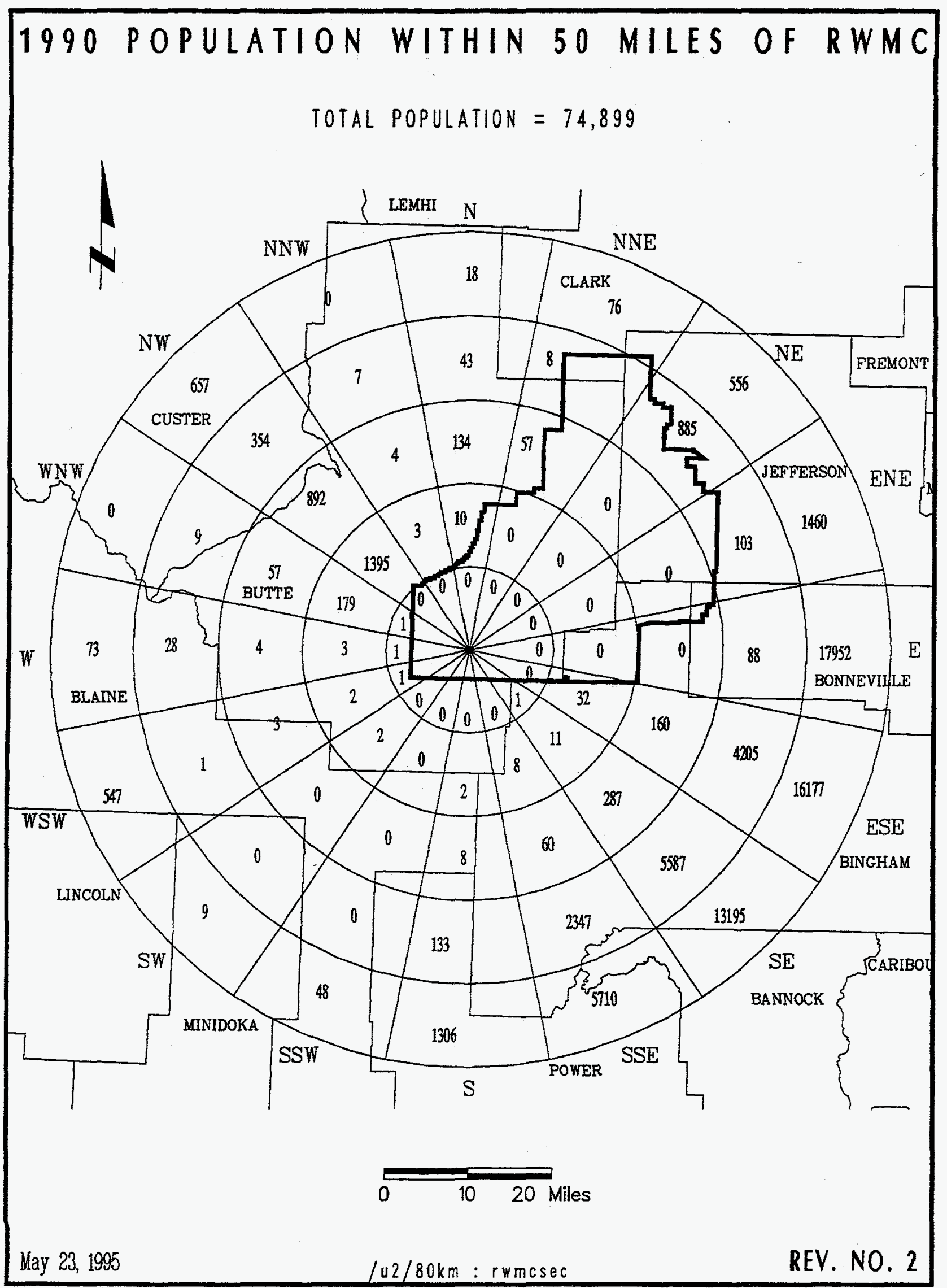

Figure 1-9. Population within 50 miles of RWMC (WAGs 6 and 7). 
1.3.3.2 Agriculture, Ranching, and Forestry. In the seven-county area surrounding the INEL, there are 1,100,000 acres of cropland in use each year. Additionally, this area produces about 105,000 head of livestock annually, mostly beef cattle (EG\&G 1990).

A significant portion of the INEL is grazed by permit. However, grazing is not permitted within $2 \mathrm{mi}$ of any nuclear facility, and dairy cattle are not permitted. The number of acres of the INEL land used for grazing usually varies between 300,000 and 350,000 acres. The United States Sheep Experiment Station, located northeast of the INEL site, uses 900 acres of the INEL for a winter feed lot for approximately 6,500 breeding sheep. The Mud Lake feed lot located at the junction of Idaho Highways 28 and 33 is used primarily between mid-October and mid-May, although the facilities are maintained year round. The feed lot and grazing areas are shown in Figure 1-10.

1.3.3.3 Recreation. The INEL is bordered on the north and west by the Bitterroot, Lemhi, and Lost River mountain ranges and on the south by the Big Southern, Middle, and East Buttes. Significant portions of these largely federally owned lands are used for such recreational purposes as hunting, fishing, boating, hiking, cross-county skiing, and camping. Specific recreational and tourism sites are nearby at the Craters of the Moon National Monument, Hell's Half Acre lava flow, Camas National Wildlife Refuge, Market Lake State Wildlife Management Area, and the Birch Creek Camping Area. In addition, there are two National Forests, Challis and Targhee, within $50 \mathrm{mi}$ of the north and west INEL boundaries, respectively.

Public tours are conducted at the INEL. Tours are held throughout the year for the general public and special interest groups.

Controlled hunts conducted by the Idaho Fish and Game Department have been permitted on the INEL (DOE 1989).

1.3.3.4 Transportation. The INEL and commercial transportation systems include road and highway systems, railroad systeras, and airports. Approximately 5\% of INEL land (about 28,450 acres) is devoted to public road and utility right-of-ways crossing the site.

The INEL site has $87 \mathrm{mi}$ of paved roads within its boundaries, about $18 \mathrm{mi}$ of which are considered service roads. Road use is restricted to employees and visitors on official business. An additional $90 \mathrm{mi}$ of paved highways run through the INEL and is used by the general public: United States Highways 20 and 26 cross the southern portion and Idaho State Highways 22, 28, and 33 cross the northern portion of the site (see Figure 1-1). Over $100 \mathrm{mi}$ of unpaved roads and trails provide additional access for emergency, security, and service vehicles.

The Union Pacific Railroad's Mackay Branch Line services the southern portion of the INEL through the Scoville Spur. Freight services are received from the Union Pacific Railroad's main lines from Butte, Montana, on the north and Pocatello, Idaho, and Salt Lake City, Utah, on the south. Interconnections are made from these locations throughout the United States. The INEL freight comes through Blackfoot, Idaho, from the Union Pacific's north-south track over the Mackay Branch Line. There are $14 \mathrm{mi}$ of Mackay Branch Line traversing the southern part of the INEL site (see Figure 1-1). 


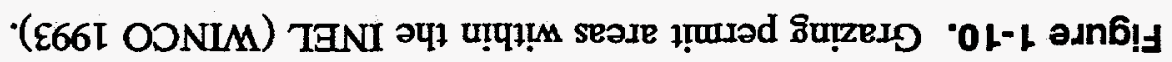
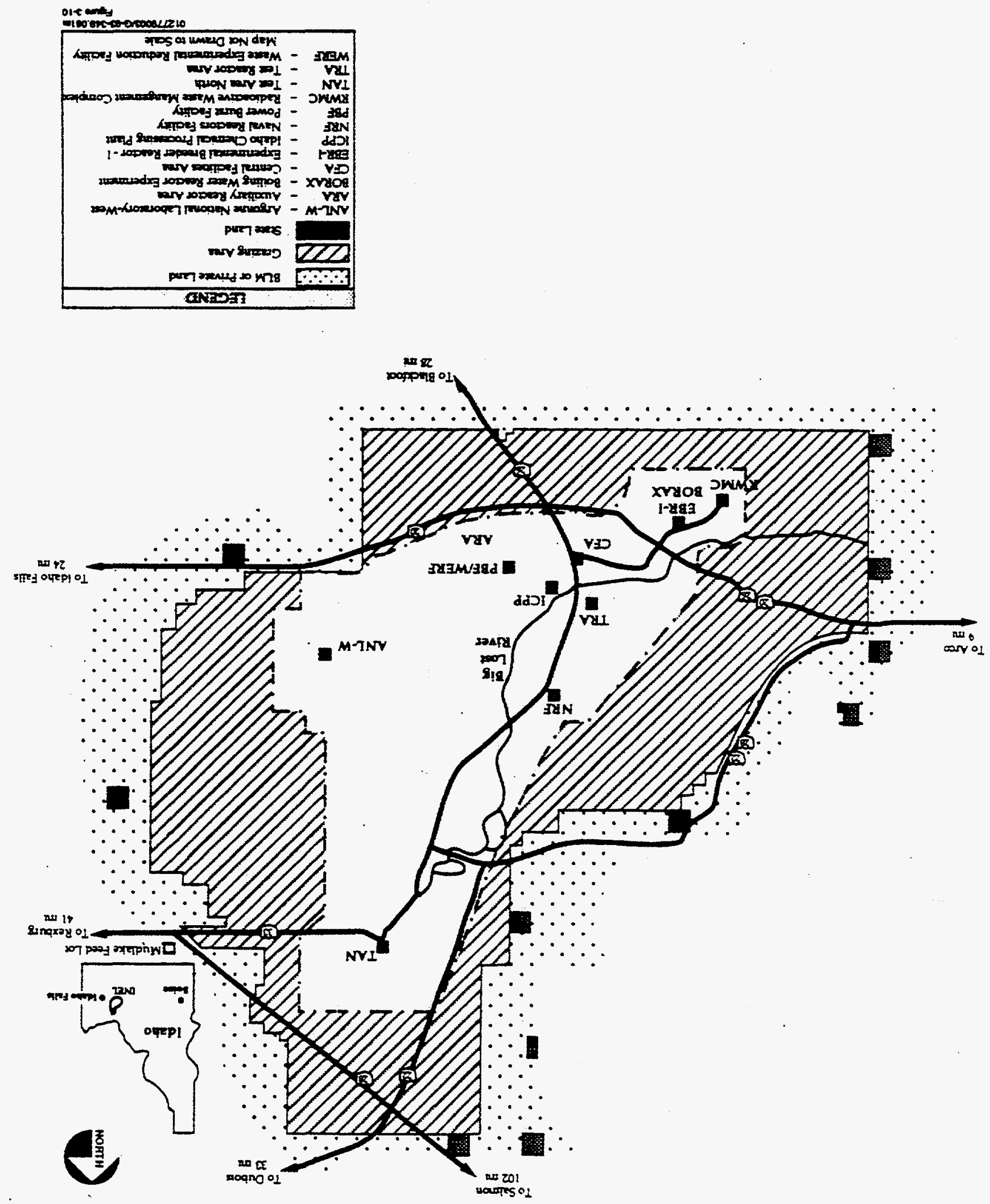
A DOE-owned railroad track passes north at the Scoville Siding from the Mackay Branch through CFA, past the east side of the ICPP, and terminates within the NRF. A spur line runs west to connect this track through the south end of ICPP's Fuel Storage Facility (CPP-603) to the coal-fired plant; a portion of this line is presently out of service. A separate rail system is located at TAN and was used to move large items, such as transport casks for spent nuclear fuel, to and from the TAN Hot Shop Complex. This rail system is currently out of service and out of compliance, thus cannot be used.

The cities of Idaho Falls and Pocatello both have airports which receive jet and turboprop air passengers and cargo service from two major carriers, and commuter service from two other carriers. There is a helicopter landing pad at each of the major facilities and the main helicopter pad is located at the CFA-608 security checkpoint. No major air routes cross the INEL.

1.3.3.5 Utilities. Commercial electric power and power generated onsite are delivered to the operating areas at the INEL by an extensive power transmission system. The system is a loop configuration with $56.5 \mathrm{mi}$ of 138 -kilovolt $(\mathrm{kV})$ transmission line, more miles of secondary voltage feeder lines, and seven major substations with a cumulative transformer capacity of 122.6 megavolt amperes.

No gas or oil lines distribute fuels throughout the INEL. Each facility may have propane or diesel tanks for fuel storage.

\subsection{Environmental Description}

This section contains descriptions of the meteorology, hydrology, and geology of the INEL region. Data and information needed to perform dispersion calculations are provided.

\subsubsection{Meteorology}

The climate of the INEL is affected by the surrounding mountains and the location of the eastern Snake River Plain. Because of the northeast-southwest orientation of the plain in the surrounding mountains, the prevailing wind is southwesterly. The Centennial and Beaverhead mountain ranges to the north act as a barrier to movement of most of the cold winter air passing to the south out of Canada. Air masses entering the INEL are relatively dry because heavy precipitation has occurred in crossing mountain barriers. Therefore, annual rainfall is light, cloud cover is sparse, and the air is relatively dry.

The U.S. Weather Bureau established a complete Weather Bureau station at the INEL in 1949. Meteorologists and technicians were responsible for collecting climatological observations hourly and daily. The National Oceanic and Atmospheric Administration (NOAA) continues to furnish forecast and emergency support. Wind direction and speed, air temperature, and precipitation have been recorded at CFA since 1949. Weather conditions have also been recorded, on a smaller scale, at TAN. In addition to recording day-to-day weather data and providing daily operational forecasts for the INEL, NOAA staff maintains an intensive research and development program. The program's purpose is to improve the reliability of prediction and measurement of meteorological parameters that influence safe conduct of operations at the INEL. 
The meteorological observation program researches transport, diffusion, and deposition of airborne effluents at the INEL.

Continuous measurements are made from 30 stations in and around the INEL. The meteorological stations simultaneously measure the spatial variation of several meteorological parameters, such as temperature, wind speed, and wind direction up to a height of $250 \mathrm{ft}$. Telemetered wind measurements, usually at $50 \mathrm{ft}$ above ground, are collected at those stations. Wind, temperature, precipitation, and atmospheric transport data and information are included in the sections below. These data and information were obtained from a compilation of INEL climatological observations and studies conducted to evaluate aspects of meteorology and diffusion from 1949 through 1988 (Clawson 1989). Meteorological information is presented only for CFA and TAN. However, the CFA data are representative of all areas of INEL except TAN, which is located farther north and closer to mountains, making the weather patterns at TAN somewhat different.

1.4.1.1 Wind. Wind speed and direction have been continuously monitored at a large number of stations on and surrounding the INEL since 1950. Winds at the INEL typically blow from the southwest, moving up the eastern Snake River Plain. Winds from the northeast are also common, especially at night when the daytime flows are reversed by movement of cool air back down the Snake River Plain. The wind directions at TAN are modified by the broad northwestto-southeast orientation of the Birch Creek valley. This valley channels strong north-northwest winds into the TAN area.

Average monthly near-surface [6-m (20-ft) height] wind speeds are highest in the month of April, with speeds of $15 \mathrm{~km} / \mathrm{hr}(9.3 \mathrm{mph})$ at CFA and $15.3 \mathrm{~km} / \mathrm{hr}(9.5 \mathrm{mph})$ at TAN. The peak wind gusts recorded at $6 \mathrm{~m}(20 \mathrm{ft})$ above ground at CFA and TAN are $125 \mathrm{~km} / \mathrm{hr}(78 \mathrm{mph})$ and $108 \mathrm{~km} / \mathrm{hr}(67 \mathrm{mph})$, respectively.

1.4.1.2 Temperature. The INEL is characterized as a cool, high desert. During the summer, days are warm and nights are cool; in winter, days and nights are cold. The limited rainfall, relatively dry air, and infrequent low clouds permit intense solar heating of the surface during the day and rapid radiational cooling at night. These factors combine to produce a large daily temperature range near the ground. The Centennial and Bitterroot mountain ranges to the north keep most of the intensely cold, Canadian winter air masses from intruding into the eastern Snake River Plain. Occasionally, cold air spills over the mountains, producing low temperatures at the INEL for periods lasting a week or longer.

Surface air temperatures at the INEL are best characterized by two stations: CFA and TAN. Temperature averages were calculated using data collected over a 39-yr period (1950 to 1988) at CFA. The annual average temperature is $5.5^{\circ} \mathrm{C}\left(42^{\circ} \mathrm{F}\right)$, with recorded extremes of $-44^{\circ} \mathrm{C}\left(-47^{\circ} \mathrm{F}\right)$ and $38^{\circ} \mathrm{C}\left(101^{\circ} \mathrm{F}\right)$. Average daily temperatures range from a low of $2.5^{\circ} \mathrm{C}\left(10^{\circ} \mathrm{F}\right)$ in January to a high of $21^{\circ} \mathrm{C}\left(70^{\circ} \mathrm{F}\right)$ on several days in late July.

The 30-yr normalized average daily air temperature at TAN ranges from a low of $10.5^{\circ} \mathrm{C}$ $\left(13^{\circ} \mathrm{F}\right)$ during mid-January to a high of $21^{\circ} \mathrm{C}\left(70^{\circ} \mathrm{F}\right)$ in late July. The annual average temperature is $5.7^{\circ} \mathrm{C}\left(42.2^{\circ} \mathrm{F}\right)$. The hottest and coldest air temperatures ever recorded are $39^{\circ} \mathrm{C}$ and $-45^{\circ} \mathrm{C}$ $\left(103^{\circ} \mathrm{F}\right.$ and $\left.-49^{\circ} \mathrm{F}\right)$, respectively. The average frost-free period at TAN is 86 days, and the shortest 
recorded frost-free period is 64 days. An average of $42 \%$ of the days contains a freeze/thaw cycle. The average maximum depth of freezing temperatures in the soil is approximately $1 \mathrm{~m}(3.3 \mathrm{ft})$. Freezing temperatures have been recorded to a maximum depth of $1.5 \mathrm{~m}(5 \mathrm{ft})$.

1.4.1.3 Precipitation. Considerable precipitation variability is characteristic of the INEL area. Although the total amount is light, precipitation can be expected in any month of the year. There have also been several months when no precipitation has been recorded. The type of precipitation also varies depending on the season. The average annual precipitation (water equivalent) between 1950 through 1.988 at CFA is $22.1 \mathrm{~cm}$ (8.71 in.). At TAN, the annual average is $19.9 \mathrm{~cm}$ ( $7.85 \mathrm{in}$.) for the period 1950 through 1964 . The monthly averages for the same periods show peaks in May and June, with 3.05 and $3.00 \mathrm{~cm}(1.20$ and $1.19 \mathrm{in}$.) at CFA and 3.48 and $3.02 \mathrm{~cm}$ (1.37 and $1.19 \mathrm{in}$.) at TAN. The highest annual precipitation recorded was 36.6 $\mathrm{cm}$ (14.4 in.) at CFA and $39.6 \mathrm{~cm}$ (15.6 in.) at TAN. The greatest one-hour precipitation recorded was $2.92 \mathrm{~cm}(1.15 \mathrm{in}$.) in the month of June at TAN and the greatest 24-hr precipitation recorded was $4.52 \mathrm{~cm}$ (1.78 in.) in the month of May, also at TAN.

The highest monthly average snowfall (measured at CFA; insufficient records are available for TAN) is $16.3 \mathrm{~cm}$ (6.4 in.), occurring during the month of December. For the month of January, the highest average snowfall is $15.5 \mathrm{~cm}(6.1 \mathrm{in}$.). The maximum recorded snowfall during any 24-hr period is $21.8 \mathrm{~cm}$ (8.6 in.), which occurred during the month of March. Snowfall as late as May and as early as September bas been recorded at the INEL. The greatest average monthly snow depth measured was $50.8 \mathrm{~cm}$ ( $20 \mathrm{in}$.) in March.

A statistical analysis of precipitation data from CFA for the period 1950 through 1990 was made to determine estimates for the 25- and 100-yr maximum 24-hr precipitation amounts and also 25- and 100-yr maximum snow depths (Kaminsky 1994). Results from this study indicate 3.43 $\mathrm{cm}$ (1.35 in.) of precipitation for a $25-\mathrm{yr}, 24-\mathrm{hr}$ storm event, and $4.1 \mathrm{~cm}$ (1.6 in.) of precipitation for a 100-yr, 24-hr storm event. The expected 25 -yr maximum snow depth is $57.4 \mathrm{~cm}$ (22.6 in.) and the $100-y r$ maximum snow depth is $77.8 \mathrm{~cm}$ (30.6 in.).

1.4.1.4 Atmospheric Transpiort. Depending on weather conditions at the time of a release of material to the atmosphere, the plume of material can travel in a variety of trajectories away from the INEL. The most common pattern is characterized by a southwesterly movement of the effluent plume. It results from a sustained flow from the northeast, and occurs most frequently in the fall. The next most persistent trajectory is characterized by a steady plume movement in a northerly direction directly off the INEL. Vertical atmospheric diffusion causes annual mixing depths of approximately $366 \mathrm{~m}(1,200 \mathrm{ft})$ above ground level for mornings and approximately $2,088 \mathrm{~m}(6,840 \mathrm{ft})$ above ground level for afternoons.

Estimates of the marginal and joint probability distributions of stability class and wind speed were developed for various INEL facilities for estimating dispersion of airborne contaminants as they move downwind from their sources (Einerson 1994). The 95th percentile estimates of the univariate probability distribution of the stability classes and wind speeds at various INEL facilities at the 10-m height are listed in Table 1-3. Results using both the Hilsmeier-Gifford (H-G) and Markee methods are shown for downwind distances of $100 \mathrm{~m}$ and $10 \mathrm{~km}$. They are intended to be used when percentile meteorological conditions (e.g., straight line estimates of $95 \%$ weather conditions without regard to wind clirection) are required for air dispersion modeling during 
Table 1-3. Atmospheric wind stability parameters for the $10-\mathrm{m}$ height at INEL facilities.

\begin{tabular}{lcccccccc}
\hline & \multicolumn{2}{c}{ H-G at $100 \mathrm{~m}$} & \multicolumn{2}{c}{ H-G at $10 \mathrm{~km}$} & \multicolumn{2}{c}{ Markee at $100 \mathrm{~m}$} & \multicolumn{2}{c}{ Markee at $10 \mathrm{~km}$} \\
\cline { 2 - 9 } Facility & $\begin{array}{c}\text { Stability } \\
\text { class }\end{array}$ & $\begin{array}{c}\text { Speed class } \\
\text { midpoint } \\
(\mathrm{m} / \mathrm{s})\end{array}$ & $\begin{array}{c}\text { Stability } \\
\text { class }\end{array}$ & $\begin{array}{c}\text { Speed class } \\
\text { midpoint } \\
(\mathrm{m} / \mathrm{s})\end{array}$ & $\begin{array}{c}\text { Stability } \\
\text { class }\end{array}$ & $\begin{array}{c}\text { Speed class } \\
\text { midpoint } \\
(\mathrm{m} / \mathrm{s})\end{array}$ & $\begin{array}{c}\text { Stability } \\
\text { class }\end{array}$ & $\begin{array}{c}\text { Speed class } \\
\text { midpoint } \\
(\mathrm{m} / \mathrm{s})\end{array}$ \\
\hline CFA & F & 1.04 & F & 1.04 & F & 1.04 & F & 1.04 \\
TAN & F & 1.04 & F & 1.04 & F & 1.04 & F & 1.04 \\
PBF & F & 1.04 & F & 1.04 & E & 1.04 & F & 1.04 \\
TRA & F & 1.04 & F & 1.04 & E & 1.04 & F & 1.04 \\
\hline
\end{tabular}

accident conditions (i.e., short duration, short distances, and ground releases). These parameters would be used as input to the Radiological Safety Analysis Computer code, Version 5, to determine the consequences from the postulated accidents in Chapter 3 (Wenzel 1994).

\subsubsection{Hydrology}

This section provides regional and INEL-specific hydrological information, including both surface water and groundwater features.

1.4.2.1 Surface Water. Surface water is almost nonexistent at the INEL, except during years of heavy runoff or when rainfall occurs on frozen soil or snow. Most of the INEL is located in the Pioneer Basin, which is a closed topographic depression. The three streams that drain valleys in the mountain region to the north and west of the INEL-the Big Lost River, Little Lost River, and Birch Creek-are depicted in Figures 1-1 and 1-3. The integrity of these natural surface waters is protected by the Clean Water Act (33 USC 1251) and the Idaho State Administrative Policy on Protection of Waters of the State (IDAPA 516.01.02050). Stream flows are often depleted by irrigation diversions, hydropower diversions, and infiltration losses along the channel bed before reaching the INEL.

The Big Lost River is the major surface water feature at the INEL. The Big Lost River bed follows a southeasterly direction between the Lost River Range and Pioneer Mountains, draining an area of approximately $1,450 \mathrm{mi}^{2}$. Storage and diversion systems on the Big Lost River include the Mackay Dam [located $48 \mathrm{~km}$ (30 mi) upstream of Arco, Idaho] several irrigation diversions between the dam and the eastern Snake River Plain, and the INEL flood diversion dam (Kaminsky 1994; Mundorff 1964). Below the Mackay Dam, water flows southeastward past Arco, and enters the INEL at the southern part of its western boundary.

The Big Lost River does not typically flow onto the INEL. It flowed onto the INEL in 1987,1993 , and 1995, but not in the intervening years because of the prolonged drought conditions in southeastern Idaho and increased irrigation demands. If the Big Lost River does actually reach the INEL, it is either diverted by the INEL diversion dam or flows in a northeasterly direction to the Big Lost River sinks, where the water is lost to evaporation and infiltration. 
The annual discharge of the Big Lost River, measured below the Mackay Reservoir, exceeded $4.9 \times 10^{8} \mathrm{~m}^{3} / \mathrm{yr}(400,000 \mathrm{acre}-\mathrm{ft} / \mathrm{yr})$ in 1965,1983 , and 1984 . The average annual discharge of the Big Lost River measured below the Mackay Dam is $2.8 \times 10^{8} \mathrm{~m}^{3} / \mathrm{yr}(2.28 \times$ $10^{5}$ acre-ft/yr) (Bowman 1985).

The Birch Creek basin is an elongated, southeast trending valley located between the Lemhi and Beaverhead mountain ranges, with a drainage area of about $750 \mathrm{mi}^{2}$. Birch Creek originates from springs below Gilmore Summit in the Beaverhead Mountains and flows in a southeasterly direction onto the Snake River Plain. Water in the creek is diverted northeast of the INEL for irrigation and hydropower during the summer months. In the winter months, water is returned to the main Birch Creek channel within the INEL boundary. This channel leads to a gravel pit, located $6.4 \mathrm{~km}(4 \mathrm{mi})$ north of TAN, where creek waters infiltrate the gravel pit bottom. However, if the flow is interrupted, the channel and pit bottom may freeze, reducing infiltration rates. In this event, a second channel is used to divert the flows to a second gravel pit, located to the east away from TAN. Birch Creek discharges, measured about $6.4 \mathrm{~km}$ (4 mi) upstream of the INEL northern boundary, are characteristic of a stable stream fed by groundwater, with low flows of $2.1 \mathrm{~m}^{3} / \mathrm{s}\left(75 \mathrm{ft}^{3} / \mathrm{s}\right)$ and very consistent discharges. The predicted 100 -yr peak flow is $3.3 \mathrm{~m}^{3} / \mathrm{s}$ $\left(116 \mathrm{ft}^{3} / \mathrm{s}\right)$ and the average annual discharge is $7.0 \times 10^{7} \mathrm{~m}^{3} / \mathrm{yr}\left(5.7 \times 10^{4}\right.$ acre-ft/yr) (Bowman 1985).

The Little Lost River drains the slopes of the Lemhi and Lost River mountain ranges. The drainage area for the basin northwest of Howe is $705 \mathrm{mi}^{2}$. Little Lost River streamflow is diverted for irrigation north of Howe and does not flow onto the INEL. The average annual discharge of the Little Lost River, rneasured approximately $11 \mathrm{~km}(7 \mathrm{mi})$ northwest of Howe, is $6.0 \times 10^{7} \mathrm{~m}^{3} / \mathrm{yr}\left(5.7 \times 10^{4}\right.$ acre-ft/yr) (Bowman 1985).

Ponding conditions on the INIEL often result from heavy rainstorms or from rapid snow melt, particularly if the ground is frozen. Snowmelt runoff occurs on the INEL in January, February, and March, and runoff from the surrounding mountains generally occurs in May or June. The ground is usually frozen from late November until late February or early March. Although precipitation on the INEL is limited, heavy rainfall is more common during the months of May, June, August, and September than other months.

1.4.2.2 Groundwater. The Snake River Plain Aquifer is a continuous body of groundwater underlying nearly all of the eastern Snake River Plain. Depths to the water table from the INEL land surface range from about $200 \mathrm{ft}$ in the northern part of the site to more than $900 \mathrm{ft}$ in the south (Pittman et al. 1988). Aquifer boundaries are formed by contact of the aquifer with less permeable rocks at the margins of the plain (Mundorff 1964). These boundaries correspond to the mountains on the west and north, and the Snake River on the east. The aquifer is approximately $325 \mathrm{~km}$ (200 mi) long, 65 to $95 \mathrm{~km}$ (40 to $60 \mathrm{mi}$ ) wide, and covers an area of approximately $25,000 \mathrm{~km}^{2}\left(9,600 \mathrm{mi}^{2}\right)$. It extends from Hagerman, Idaho, on the west to near Ashton, Idaho, northeast of the INEL.

The aquifer is composed of numerous, relatively thin basalt flows extending to depths in excess of $1,067 \mathrm{~m}(3,500 \mathrm{ft})$ below land surface. Over time, some of these flows have been exposed at the surface long enough to collect sediment. These sedimentary interbeds are sandwiched between basalt flows at various depths. The thickness of the active portion of the 
Snake River Plain Aquifer at the INEL has been estimated between 75 and $250 \mathrm{~m}$ (250 to $820 \mathrm{ft}$ ) by the U.S. Geological Survey. Drilling information from a test well just south of TAN suggests that the aquifer thickness in that vicinity may be more than $274 \mathrm{~m}$ (900 ft) (Kaminsky 1994; Mundorff 1964).

Regionally, most water moves horizontally through basalt interflow zones, which are the broken, and rubble zones between lava flows. Aquifer groundwater flow is primarily in a southwest direction; however, locally, the flow direction can be affected by recharge from rivers, surface water spreading areas, and heterogeneities in the aquifer. Figure 1-11 is a map of Idaho showing the location of the INEL, the Snake River Plain, and generalized flow lines of the Snake River Plain Aquifer (Mundorff 1964). Transmissivity in the aquifer ranges from 100 to $10,000 \mathrm{~m}^{2} /$ day (1,000 to $100,000 \mathrm{ft}^{2} /$ day) and, in places, exceeds $100,000 \mathrm{~m}^{2} /$ day $\left(1 \times 10^{6} \mathrm{ft}^{2} /\right.$ day (Kaminsky 1994; Mundorff 1964). Yields of wells drilled in the Snake River basalts are among the largest in the nation. Irrigation wells open to less than $30.5 \mathrm{~m} \mathrm{(100} \mathrm{ft)} \mathrm{of} \mathrm{the} \mathrm{aquifer} \mathrm{yield} \mathrm{as}$ much a $26,500 \mathrm{~L} / \mathrm{min}(7,000 \mathrm{gal} / \mathrm{min})$ with slight drawdown; yields of 7,500 to $11,400 \mathrm{~L} / \mathrm{min}(2,000$ to $3,000 \mathrm{gal} / \mathrm{min}$ ) are common (Kaminsky 1994; Mundorff 1964).

An estimate of the amount of water stored in the Snake River Plain Aquifer was $2.5 \times 10^{12} \mathrm{~m}^{3}\left(2 \times 10^{9}\right.$ acre-ft), approximately $6.2 \times 10^{11} \mathrm{~m}^{3}\left(5 \times 10^{8}\right.$ acre-ft $)$ recoverable (Robertson 1974). Another estimate of the aquifer capacity was approximately $4.9 \times 10^{11} \mathrm{~m}^{3}(4 \times$ $10^{8}$ acre-ft) (Kaminsky 1994; Mundorff 1964).

Recharge of the aquifer near the INEL originates from precipitation in the mountains to the north, northwest, and northeast of the Snake River Plain. Most of the inflow occurs from seepage of irrigation water, stream flow and canal leakage, tributary valley underflow, and direct precipitation. The Big Lost River, Little Lost River, and Birch Creek terminate at sinks on or near the INEL and recharge the aquifer. Recharge occurs through the surface of the plain from flow in the channel of the Big Lost River and its diversion area. Additionally, recharge may occur from melting of local snowpacks during years in which snowfall accumulates on the eastern Snake River Plain.

Aquifer discharge is large spring flow to the Snake River and water pumped for irrigation. The aquifer discharges approximately $8.8 \times 10^{9} \mathrm{~m}^{3}$ (7.1 million acre-ft) of water annually to springs and rivers. Pumped water for irrigation totals approximately $2.0 \times 10^{9} \mathrm{~m}^{3}$ (1.6 million acre-ft) annually (Kaminsky 1994; Mundorff 1964). Water levels in wells have decreased since the 1950 s because of annual increases in groundwater pumpage. Based on a modeled aquifer, if 1980 conditions of recharge and discharge are extended to the year 2010, aquifer declines of .6 to $2.4 \mathrm{~m}$ ( 2 to $8 \mathrm{ft}$.) could be expected. However, if withdrawals were increased by $68 \mathrm{~m}^{3}\left(2,400 \mathrm{ft}^{3}\right)$ per second to irrigate another $4000 \mathrm{~km}^{2}$ (1 million acres), wellhead water level declines of 3 to $15 \mathrm{~m}$ (10 to $50 \mathrm{ft}$.) might be expected within 30 years (Garabedian 1986).

Most groundwater pumped from the aquifer is used to irrigate crops. However, because groundwater supplies the drinking water consumed within the eastern Snake River Plain and an alternative drinking water source or combination of sources is not available in some areas, the U.S. Environmental Protection Agency (EPA) designated the Snake River Plain Aquifer as a sole-source aquifer in 1991 (Fed Reg 1991) pursuant to the Safe Drinking Water Act ("Safe Drinking Water Act," 42 USC 300, 40 CFR 141-149). Because the aquifer has been designated 


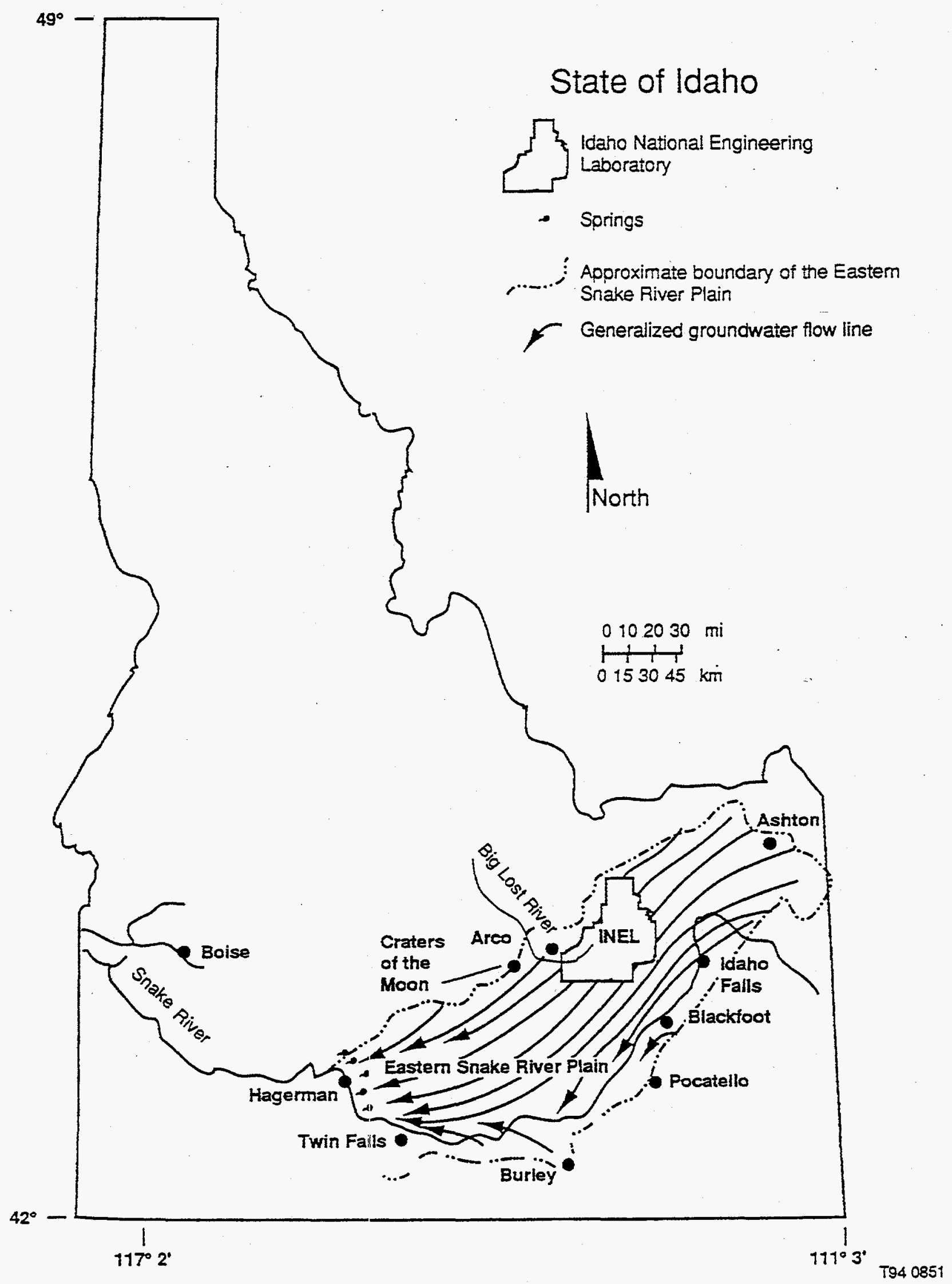

Figure 1-11. Map of Idaho showing the location of the INEL and eastern Snake River Plain, and generalized flow lines of the Snake River Plain Aquifer. 
as a sole-source aquifer, no Federal financial assistance may be committed for any project if the EPA determines that the project may contaminate the aquifer through the recharge zone, creating a significant hazard to public health.

Perched water bodies have been detected at the ICPP, TRA, TAN, and RWMC facilities. They are generally related to the presence of disposal ponds or other surface water sources.

The natural groundwater chemistry of the Snake River Plain Aquifer beneath the INEL is influenced by the chemical composition of groundwater originating outside of the INEL; precipitation, streams, rivers, and runoff; and the weathering reactions that occur as water interacts with the minerals composing the aquifer (Wood and Low 1986; 1988). These processes result in water containing relatively high concentrations of calcium and bicarbonate as well as other components. However, the chemical composition of natural groundwater beneath the INEL does not exceed the EPA maximum contaminant level for any component.

\subsubsection{Geology}

This section provides geological information, including historical data, results of investigations, and information about soil structures in the INEL region and at TAN. The following information is summarized from Kaminsky 1994, and Mundorff 1964.

1.4.3.1 Regional Geology. The INEL lies in a topographic depression on the northwestern edge of the eastern Snake River Plain, an 87-km- (54-mi)-wide, northeast-trending volcanic province, extending from the vicinity of Twin Falls, on the southwest to Yellowstone National Park on the northeast. The geological setting of the INEL is depicted in Figures 1-12 and 1-13.

The eastern Snake River Plain lies within the northeastern part of the basin and range province of southern Idaho, and truncates basin and range structures on the northwest and southeast with 1,207 to $1,408 \mathrm{~m}(3,960$ to $4,620 \mathrm{ft})$ of relief between the ranges and relatively flat plain. The mountain ranges north of the plain are composed of Paleozoic sedimentary rocks that have been folded and faulted. The northern basin and range province is composed of north-tonorthwest-trending mountain ranges [with peaks up to $3,700 \mathrm{~m}(12,100 \mathrm{ft})$ ], separated by intervening basins 1,400 to $1,600 \mathrm{~m}(4,600$ to $5,250 \mathrm{ft})$ in elevation that are filled with terrestrial sediments and volcanic rocks.

Other regional geological provinces that also correspond to tectonic or seismotectonic provinces are the Yellowstone Plateau and the Idaho Batholith. The Yellowstone Plateau is a volcanic plateau at about 2,100 to $2,600 \mathrm{~m}(6,890$ to $8,530 \mathrm{ft})$ in elevation that is underlain by Pleistocene rhyolitic volcanic rocks. The plateau is characterized by extremely high heat flow from the surface, extremely high temperatures at shallow depths, abundant hot spring, fumarolic, and geyser activity, and landforms controlled by thick rhyolitic lava flows. The Idaho Batholith is characterized by a large area of irregular mountainous terrain with peaks ranging in elevation from 2,400 to $3,700 \mathrm{~m}(7,870$ to $12,100 \mathrm{ft})$. Streams dissecting the area usually have dendritic drainage patterns that reflect the homogeneous nature of the underlying granitic rocks that comprise the batholith. 


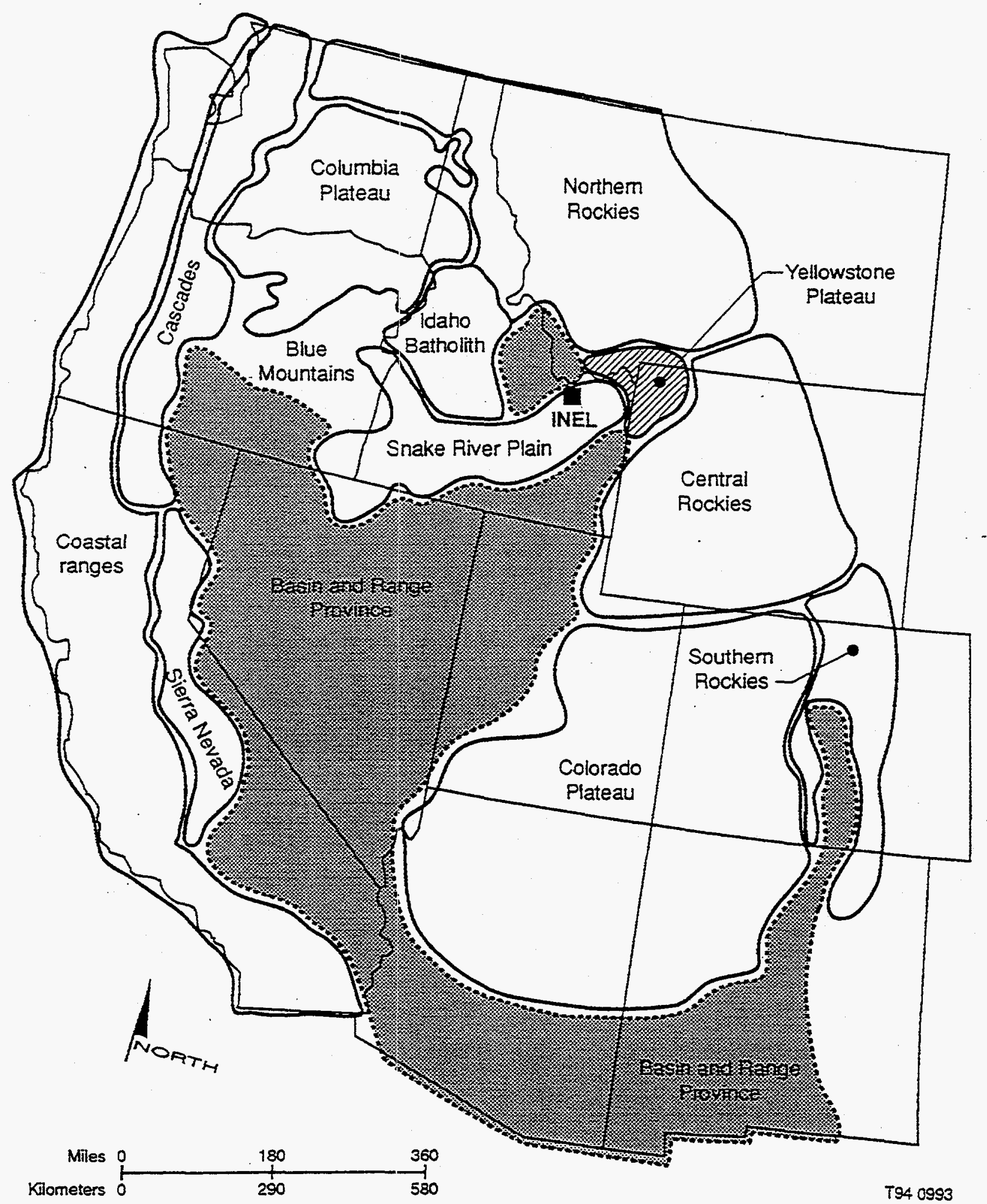

Figure 1-12. Location of the INEL, within the context of the physiographic regions of the western United States. 

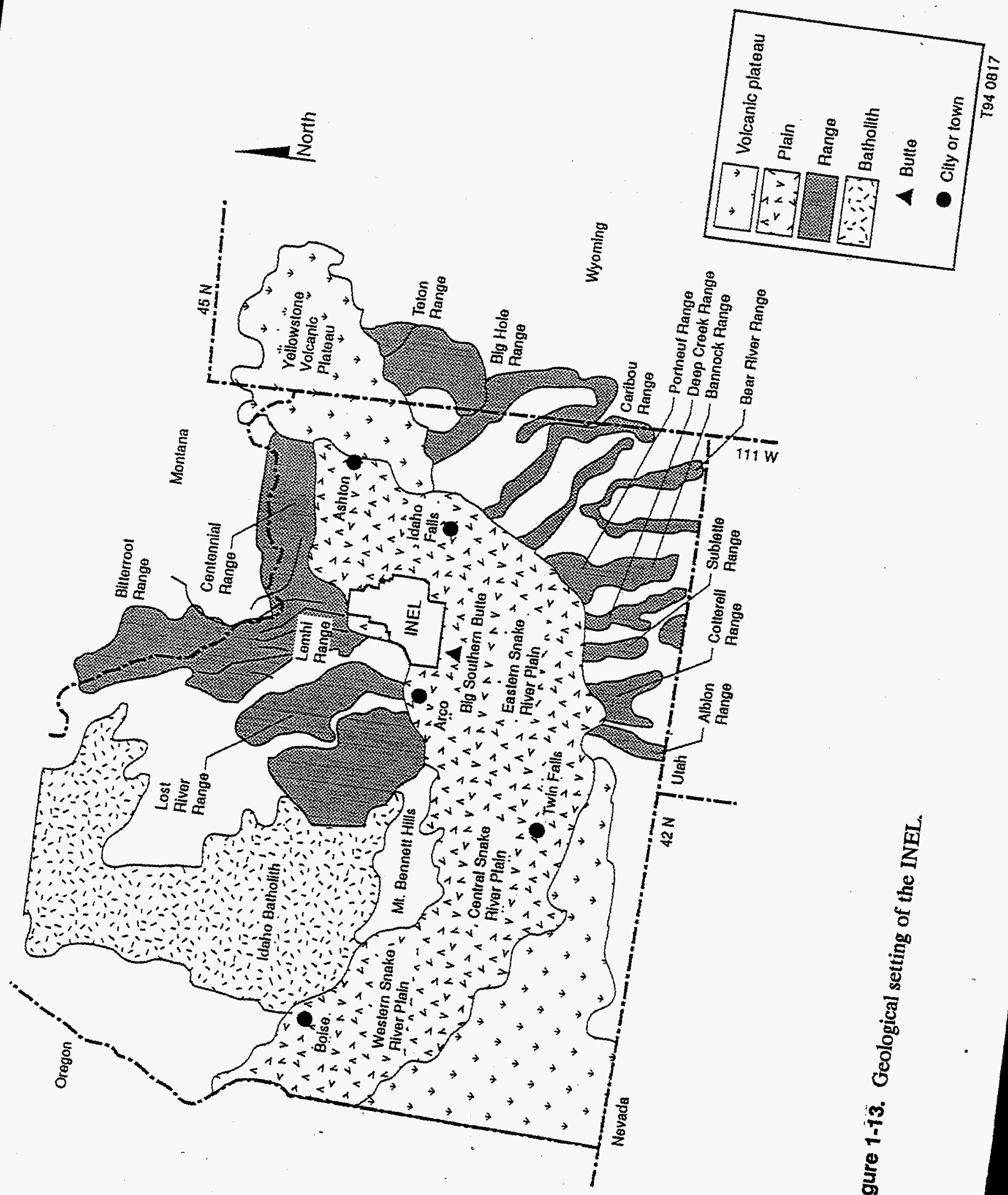
The eastern Snake River Plairl formed as a result of the movement of the North American continent over hot mantle rocks that now reside beneath Yellowstone National Park (Pierce 1992). During the past 17 million years, extension of the crust has produced northwest-trending normal faults and mountain ranges. The Yellowstone hotspot was beneath the INEL area approximately 4.3 to 6.5 million years ago.

Volcanic activity, mostly in the form of basaltic lava flows, occurred on the eastern Snake River Plain during the past 4 million years (Kuntz 1992). The volcanic rift zones and axial volcanic zone depicted in Figure 1-14 contain the vents from this basaltic volcanism. During this time, wind action, streams, and lakes caused sediments to be deposited. Basaltic lava flows are interlayered with poorly consolidated sedimentary interbeds to depths of about 2,500 to $3,700 \mathrm{~m}$ $(8,200$ to $12,100 \mathrm{ft}$ ) beneath the INEL. This sequence is underlain by a large layer (of unknown thickness) of rhyolitic ash flow deposits.

Rhyolite dome building occurred along the axial volcanic zone about 1.2 million years ago. These domes include Big Southern Butte ( 0.3 million years ago), East Butte (0.6 million years ago), an unnamed dome between East Butte and Middle Butte (1.2 million years ago), a dome in the Cedar Butte volcanic system ( 0.4 million years ago), and one probably beneath Middle Butte (age unknown) (Kaminsky 1994; Mundorff 1964).

Surface rocks (bedrock outcrops) on and near the INEL are mostly Quaternary basalt lava flows. The surface of much of the INEL is covered with unconsolidated deposits of various ages and origins. A wide band of Quaternary mainstream alluvium extends along the course of the Big Lost River from the southwestern corner of the INEL to the Big Lost River sinks in the northcentral portion of the INEL. Lacustrine deposits of clays, silts, and sands deposited in Pleistocene-age Lake Terreton occur in the northern part of the INEL. Wind-deposited loess silts cover much of the basalt bedrock to thicknesses of up to $6 \mathrm{~m}(20 \mathrm{ft})$. Beach sands deposited at the high stand of Lake Terreton were reworked by winds in late Pleistocene and Holocene time to form large dunes in the northeastern part of the INEL. These dunes extend from near TAN to Mud Lake and are stabilized with a cover of vegetation. Alluvial fans are present along the northwest and west boundaries of the INEL at the base of the Arco Hills and the Lemhi Range (Kaminsky 1994; Mundorff 1964).

Soil parent materials on the INEL are composed of four bedrock units and surficial deposits. The four bedrock units covering the INEL include Quaternary basalts, Quaternary rhyolites, Tertiary volcanics, and Paleozoic carbonates (Scott 1982; Kuntz et al. 1992). This is depicted in Figure 1-15. Quaternary basalts cover most of the INEL with lava flows ranging in age from about 15,000 to 730,000 years. Inclusions of Quaternary rhyolites form the buttes in the southeast corner and the mountains to the north end of the site. Tertiary volcanics are limited to the buttes and Paleozoic carbonates are found only in a small portion on the northwest edge of the INEL.

Quaternary surficial deposits cover the INEL along the Big Lost River drainage and the northern portion of the INEL (see Figure 1-15). Mainstream alluvium extends along the course at the Big Lost River from the southwestern corner of the INEL to the Lost River Sinks area. In addition, the northern portion of the site is dominated by mainstream alluvium. Alluvial fan material is found along the extreme western edge of the site and near Birch Creek. Lacustrine (lake) deposits are found in the northwest portion of the site. Those deposits of alkaline clay and 


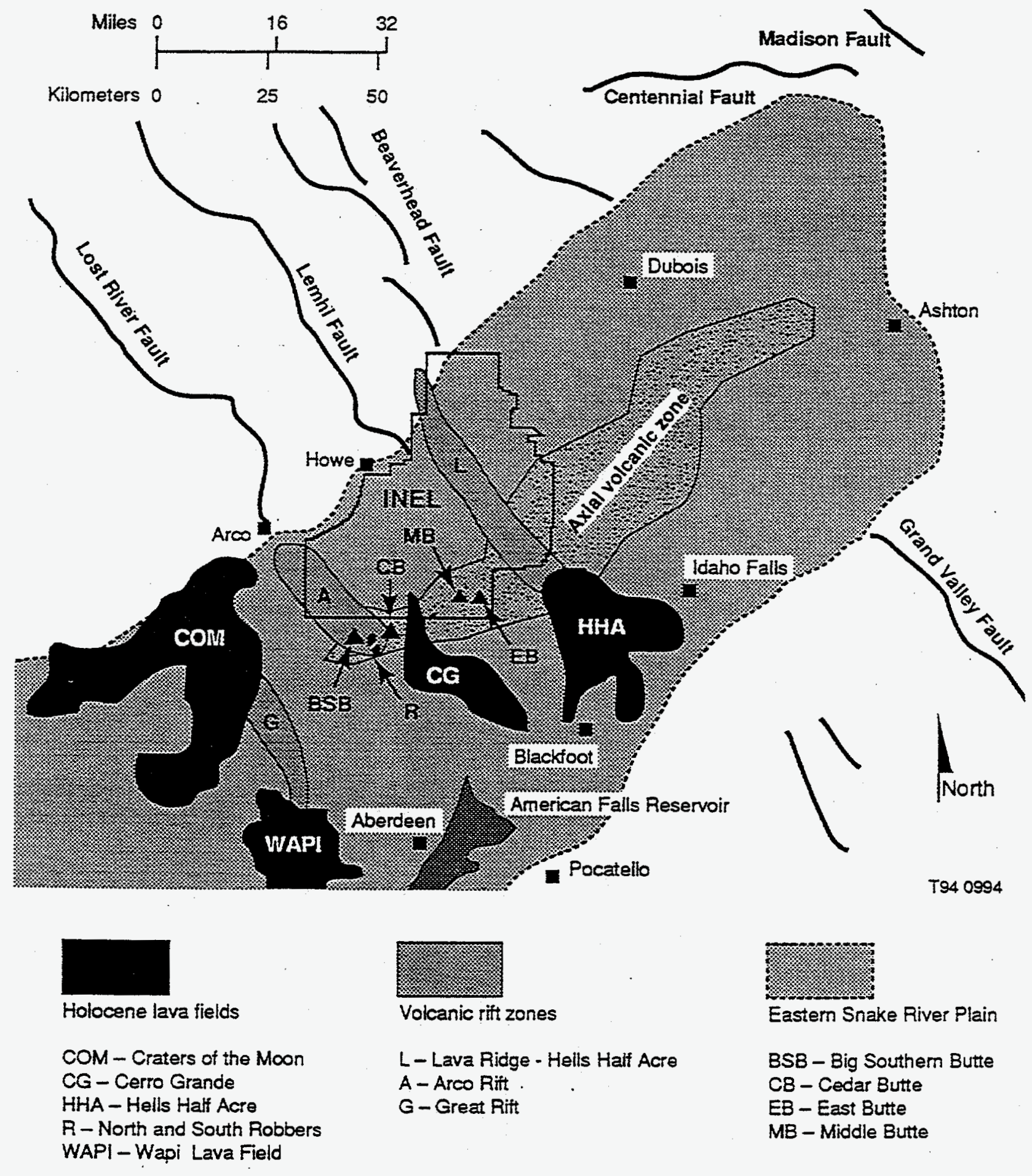

Figure 1-14. Volcanic zones in the INEL vicinity. 


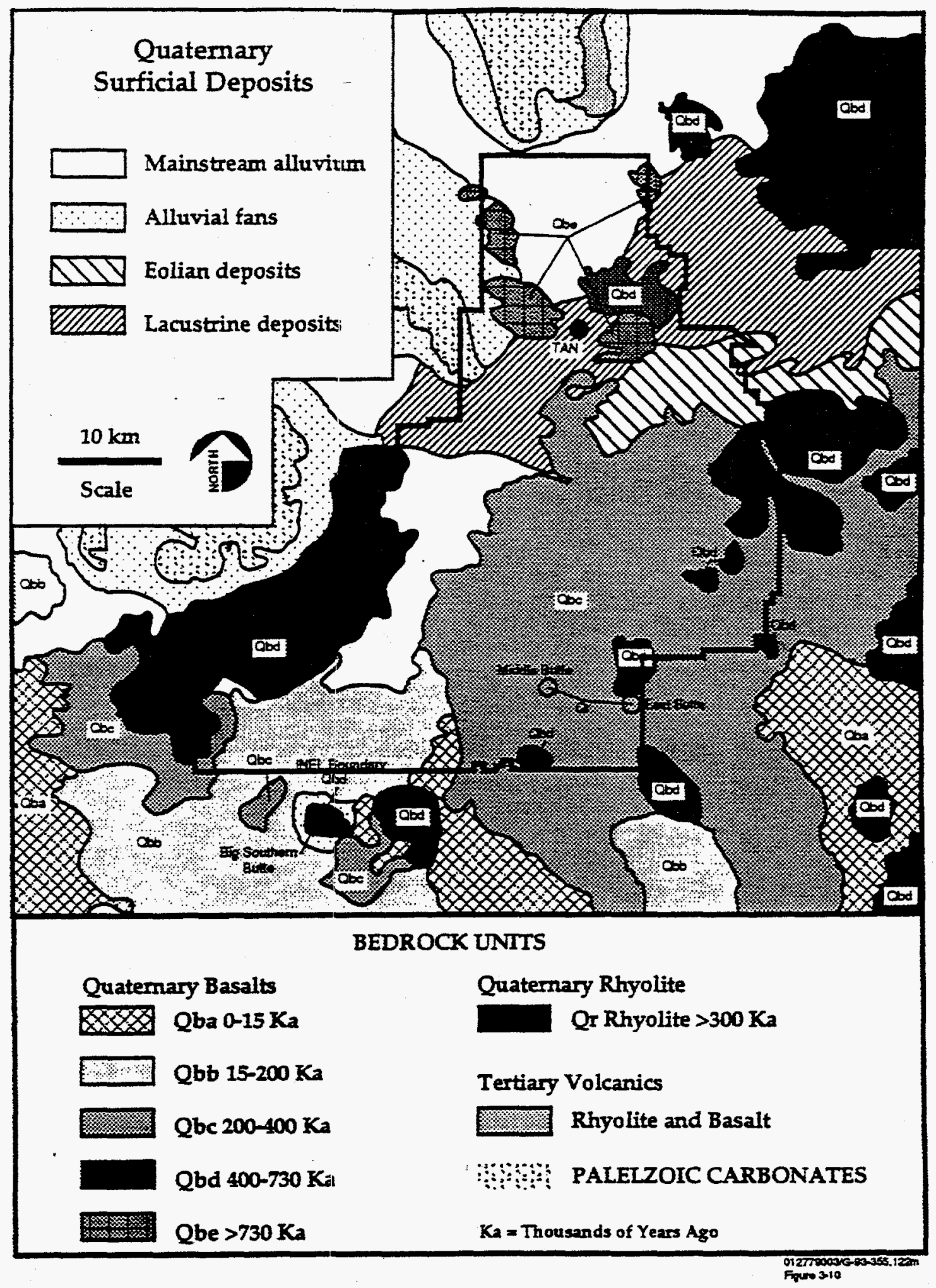

Figure 1-15. Geologic map of the INEL and adjacent area (adapted from Scott 1982; Kuntx et al. 1992). 
sand were part of Lake Terreton (which encompassed the area where the city of Howe and TAN are currently located). Eolian (wind-blown) deposits forming large dune fields are found in the east-central portion of the site. These beach sands were deposited at the high stand at Lake Terreton and were redeposited by winds in the late Pleistocene and Holocene ages.

TAN (WAG-1) is located on the lacustrine deposits of the Quaternary surficial deposits. TRA (WAG-2) and ICPP (WAG-3) are located on the mainstream alluvium of the Quaternary surficial deposits. CFA (WAG-4), BORAX (WAG-6), and RWMC (WAG-7) are located on Quaternary basalts from approximately 15,000 to 200,000 years ago. PBF/ARA (WAG-5) is located on Quaternary basalts from approximately 200,000 to 400,000 years ago.

\subsection{Natural Phenomena Threats}

Natural phenomena events that are considered to be potential accident initiators in the accident analysis addressed in Chapter 3 are discussed in this section. Data and historical information relating to the INEL are given for earthquakes (seismology), high winds and tornados, floods, volcanoes, lightning, and extreme temperatures. It is DOE policy to design, construct, and operate DOE facilities so that the workers, general public, and environment are protected from the impacts of natural phenomena hazards at DOE facilities (DOE Order 5480.28, "Natural Hazards Phenomena Mitigation").

\subsubsection{Seismology}

The eastern Snake River Plain has been characterized as a pronounced aseismic region relative to the surrounding Intermountain Seismic Belt (Smith and Arabasz 1991). Earthquake epicenters are plotted in Figure 1-16. The Intermountain Seismic Belt is a seismically active region extending from northern Arizona through Utah, along the Idaho-Wyoming border, and terminating in northwestern Montana. Figure 1-16 shows that this belt extends from the Yellowstone Plateau into central Idaho. This region has been characterized as the Centennial Tectonic Belt (Stickney and Bartholomew 1987).

1.5.1.1 Historical Seismicity. Earthquakes having magnitudes greater than 2.5 for the time period 1884-1989 are located around, but generally do not occur within, the eastern Snake River Plain (Woodward-Clyde 1992). Earthquakes that occurred before 1960 can have errors of $100 \mathrm{~km}(62 \mathrm{mi})$ or more. The U.S. Geologic Survey installed localized seismic networks in the Intermountain Seismic Belt beginning in 1960, and the NRTS (now the INEL) installed them on the eastern Snake River Plain in 1971. Thus, earthquake locations from 1960 to 1989 could have errors less than $20 \mathrm{~km}$ (12 mi). From 1972 to 1992, only 19 earthquakes (magnitudes <1.5) have been located within or near the eastern Snake River Plain by the INEL seismic network. Based on the regional and local earthquake observations, infrequently occurring small-magnitude earthquakes may be characteristic of eastern Snake River Plain seismicity (Jackson et al. 1993). However, ground motions produced by surrounding earthquakes will be transmitted onto the eastern Snake River Plain. The INEL resides within Seismic Risk Zone 2B per the Uniform Building Code (UBC 1985). 


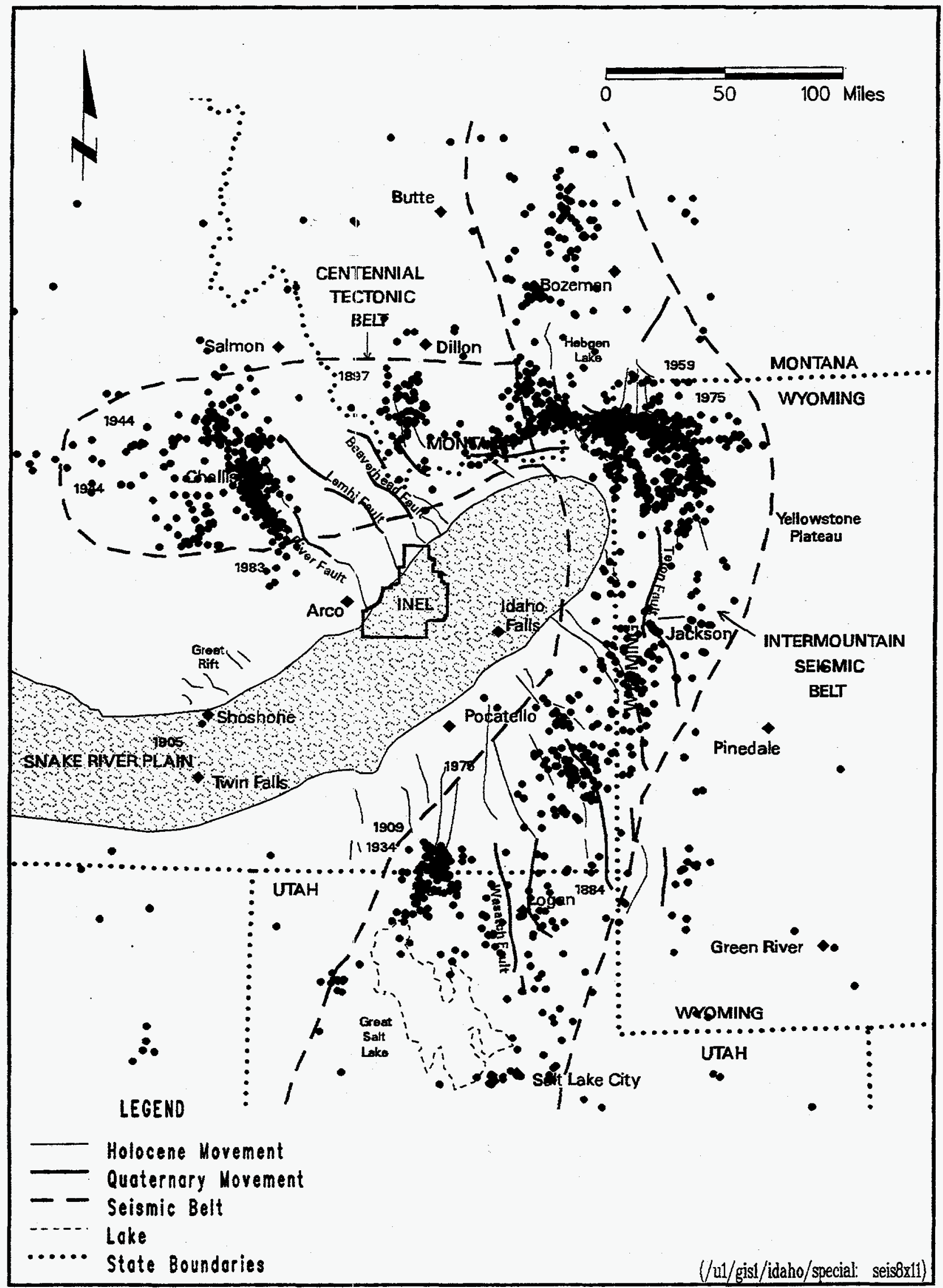

Figure 1-16. Regional seismic data. 
The historical earthquake records for the Snake River Plain and adjacent basin and range province extend back to November 10,1884, the date of the first documented earthquake, an event with an estimated magnitude of 6.3 that occurred near Paris, Idaho. By 1989, more than 3,000 earthquakes of an approximate magnitude of 2.5 and greater have been documented as occurring within the region. Forty-nine earthquakes with magnitudes of at least 5.5 have occurred in the Intermountain Seismic Belt since 1990. Twenty-three of these were at least 6.0; two were stronger than 7.0 .

The largest recorded seismic event in the Intermountain Seismic Belt occurred on August 17, 1959, and had a magnitude of 7.5. It was located near Hebgen Lake in southwestern Montana, approximately $160 \mathrm{~km}$ (100 mi) from the INEL. Seismic waveform analysis indicates that the mainshock was a double event consisting of a magnitude of 6.3 , followed five seconds later by a magnitude of 7.0 (Doser 1985). Numerous aftershocks, including one as large as a magnitude of 6.3 , shook the region for several years. Although this earthquake was felt at the INEL, no significant damage occurred. The largest earthquake in the Centennial Tectonic Belt occurred on October 28, 1983, and had a magnitude of 7.3. The earthquake resulted from slippage on a normal range-front fault, with relative movement down to the west. The epicenter for this event was along the western flank of Borah Peak in the Lost River Range, approximately 90-110 km (50-70 mi) northwest of INEL facilities. The peak horizontal acceleration measured at ground level at TAN was $0.05 \mathrm{~g}$ (Jackson 1985). No significant damage occurred at the INEL (Gorman and Guenzler 1983).

1.5.1.2 Potential Seismic Sources. The three types of seismic sources considered most significant to the INEL are (a) basin and range faults immediately north to northwest of the INEL, including the Lemhi Fault; (b) eastern Snake River Plain volcanic zones; and (c) a random "floating" earthquake (Woodward-Clyde 1992). Three major basin and range normal faults approach the northwest margin of the eastern Snake River Plain adjacent to the INEL and are considered to be significant seismic sources (see Figure 1-14). The Lost River Fault extends for $140 \mathrm{~km}(84 \mathrm{mi})$ along the western front of the Lost River Range and Arco Hills from Arco, Idaho, to Challis, Idaho. The Lemhi Fault is $150 \mathrm{~km}$ (90 mi) long and bounds the western front of the Lemhi Range. The Beaverhead Fault is $150 \mathrm{~km}$ (90 mi) in length bounding the Beaverhead Mountains.

The potential for seismicity (magnitudes of about 5.0) exists in three volcanic zones within the boundaries of the INEL that contain a concentration of volcanic features-Arco and Lava Ridge/Hells Half-Acre volcanic rift zones and axial volcanic zone (see Figure 1-14). The Circular Butte/Kettle Butte rift zone is approximately parallel to and is located within $7 \mathrm{~km}$ northwest of the Lava Ridge/Hells Half-Acre rift zone. Because TAN lies between them, the possibility of ground deformation from dike intrusion associated with volcanism in the TAN area is considered a potential hazard.

Although unlikely, a randomly located earthquake of 5.5 magnitude within the eastern Snake River Plain was considered as a possible seismic source for generating ground motions at the INEL (Woodward-Clyde 1992). Such an earthquake could occur on a currently unidentified tectonic fault. For example, the 1905 Shoshone earthquake (magnitude of 5.7) was believed to have occurred on a fault located within the eastern Snake River Plain. However, recent 
investigations of the damage by this earthquake suggest that the fault is located near the IdahoUtah border, outside the Snake River Plain (Oaks 1992).

\subsubsection{High Winds and Tornadoes}

High winds on the Snake River Plain can occur when regional atmospheric pressure gradients are sufficiently large to produce severe thunderstorms (primarily during the spring and summer months). The highest wind gust speed recorded at CFA at the 20 -ft-aboveground level was $78 \mathrm{mph}$ from the west-southwest. At the 250 -ft level, a gust of $84 \mathrm{mph}$ from the southwest was measured. At TAN, the highest wind gust speed was $67 \mathrm{mph}$ from the south at the 20-ft level and $78 \mathrm{mph}$ from the north-northwest at the 150 - $\mathrm{ft}$ level. On the average, wind speeds at the INEL exceed $15 \mathrm{mph}$ for about five to six hr/day (Clawson 1989). Peak gusts at these average speeds are 21 to $22 \mathrm{mph}$, which are sufficient to pick up and transport dust and snow. Because much of the ground is covered with grasses and brush (that form a natural wind break for the soil and bind the soil to the ground), dust or sand storms, which would have the potential for damaging structures, systems, and components at the INEL, are not common. Dust storms may be more likely as a result of a range fire that occurred on July 1, 1994, which burned 20,400 acres.

The INEL, Upper Snake River Valley, and State of Idaho in general are in an area where weather patterns are not conducive to the generation of large, severe tornadoes. Weather patterns that produce severe tornacloes in the midwestern and southwestern United States (rapidly moving cold fronts or squall lines overrunning warm, moist air) are rare in Idaho. A tornado is defined as a violent local vortex in the atmosphere that reaches the ground. If the vortex does not reach the ground, it is classified as a funnel cloud. Tornadoes and funnel clouds only occur in association with thunderstorms, especially those that produce hail. Since 1949, nine confirmed funnel clouds and four tornadoes have been documented for the Upper Snake River Valley area. Three additional funnel cloud sightings have been recorded, but the locations are unknown. NOAA records since 1950 indicate that there have been a total of five funnel clouds and no tornadoes sighted within the boundaries of the INEL (Clawson 1989). The wind hazard curve for the INEL indicates that the probability of exceeding the threshold tornado wind speed (113 mph) for any given year is less than 1.0 E-06 per year (Coats and Murray 1985).

\subsubsection{Flooding}

The INEL is located in a topographically closed basin with no surface drainage to the Snake River. Surface waters within the basin include the Big Lost River, Little Lost River, and Birch Creek, all of which drain mountain watersheds located to the north and northwest of the INEL. Local rainfall and snowmelt contribute to surface water, mainly during the spring months. Surface water is lost to evaporation or seepage into the ground, recharging the Snake River Plain Aquifer. The basin is principally composed of coarse-grained materials with moderate-to-high infiltration rates. Infiltration and depression storage losses are most significant at the Darlington sinks and Big Lost River sinks, and in Box Canyon because of its fracture basalt (Koslow and Van Haaften 1986). These features can be seen in Figure 1-17, which shows inundation resulting from failure of the Mackay Dam.

Flooding conditions at the INEL can occur with coincident melting snow and heavy spring rains. Frozen ground reduces the soil's infiltration capacity which can, if accompanied by rapid 
snowmelt, result in extensive flooding. Local runoff from rapid spring thaws has resulted in flooding of the RWMC at least three times (1962, 1969, and 1982). Similar local snowmelt flooding occurred at TAN in 1969 (Koslow and Van Haaften 1986). Ice jams in the Big Lost River and its diversion channel have threatened to flood areas at the INEL in the past (McKinney 1985). The largest flood of the Big Lost River occurred in 1965, when spreading areas $A$ and $B$ and part of $C$ were filled.

The INEL flood diversion system, a low earthen structure, was built in 1958 (and analyzed in 1984) to divert high flows from the Big Lost River that might create flood hazards to the INEL facilities. This system consists of a small dam usable for diversion of flow from the river channel into four spreading areas (Figure 1-17). The dam is located $6.5 \mathrm{mi}$ downstream from the INEL boundary. Nearly all flow is diverted during winter months to avoid ice jams in the river channel (Bennett 1986; 1990).

Because the INEL surface water flow is intermittent and controlled, high water is contained within the channel of the Big Lost River and the diversion area. Flood plains in existence prior to construction of the flood diversion system are now inactive. Based on extrapolation of previous storm events, if flow is diverted to the diversion areas, the 100- and 500-yr flood events will not result in flooding outside the banks of the existing Big Lost River channel. Flooding of the Big Lost River on the INEL might result from coincident high water and failure of the Mackay Dam (Bennett 1986; 1990). Stormwater runoff is controlled by site systems and grading to prevent localized flooding.

Koslow and Van Haaften (1986) assessed the hydrologic consequences of a potential failure of Mackay Dam and the resulting flooding of the Big Lost River. Potential failure scenarios included failure due to a seismic event; two types of structural failures; and failure caused by a probable maximum flood (PMF), providing sufficient water to top the dam. The PMF/Mackay Dam failure scenario produced significantly higher flows and a greater extent of flooding than the other scenarios. The PMF scenario represents the hypothetical flood that is considered to be the most severe flood event reasonably possible, based on hydrometeorological application of maximum precipitation and other hydrologic factors. The assessment indicated that considerable spreading of floodwaters would occur on the INEL where the plain is wide and flat, subjecting some INEL facilities to encroaching floodwaters. The water depths associated with this PMF/Mackay Dam failure flood scenario near these facilities would be from 2 to $4 \mathrm{ft}$, and the flow velocities would be low, less than $3.0 \mathrm{ft} / \mathrm{s}$. Although flood waters could be expected in the buildings, the slow-moving water would not be expected to cause structural damage. The area inundated by the PMF is shown in Figure 1-17.

On February 16, 1982, water entered the disposal pit at RWMC. Following above-average precipitation and very cold temperatures, a quick thaw, aided by wind, rain, frozen ground, and above-normal temperatures, produced a condition in which excessive surface water ran off faster than normal. Runoff water flowed around the administrative area up to the thresholds of several buildings. At the close of the workday on Tuesday, February 16, 1982, the dike around the Subsurface Disposal Area (SDA) perimeter was restricting outside runoff from entering the SDA and water levels were receding. However, on Wednesday, water had receded from the administrative areas, but the dike at the corner of the SDA was breached allowing runoff water the enter the SDA; much of the east portion of the SDA was covered with water, and pits 16,17 , 


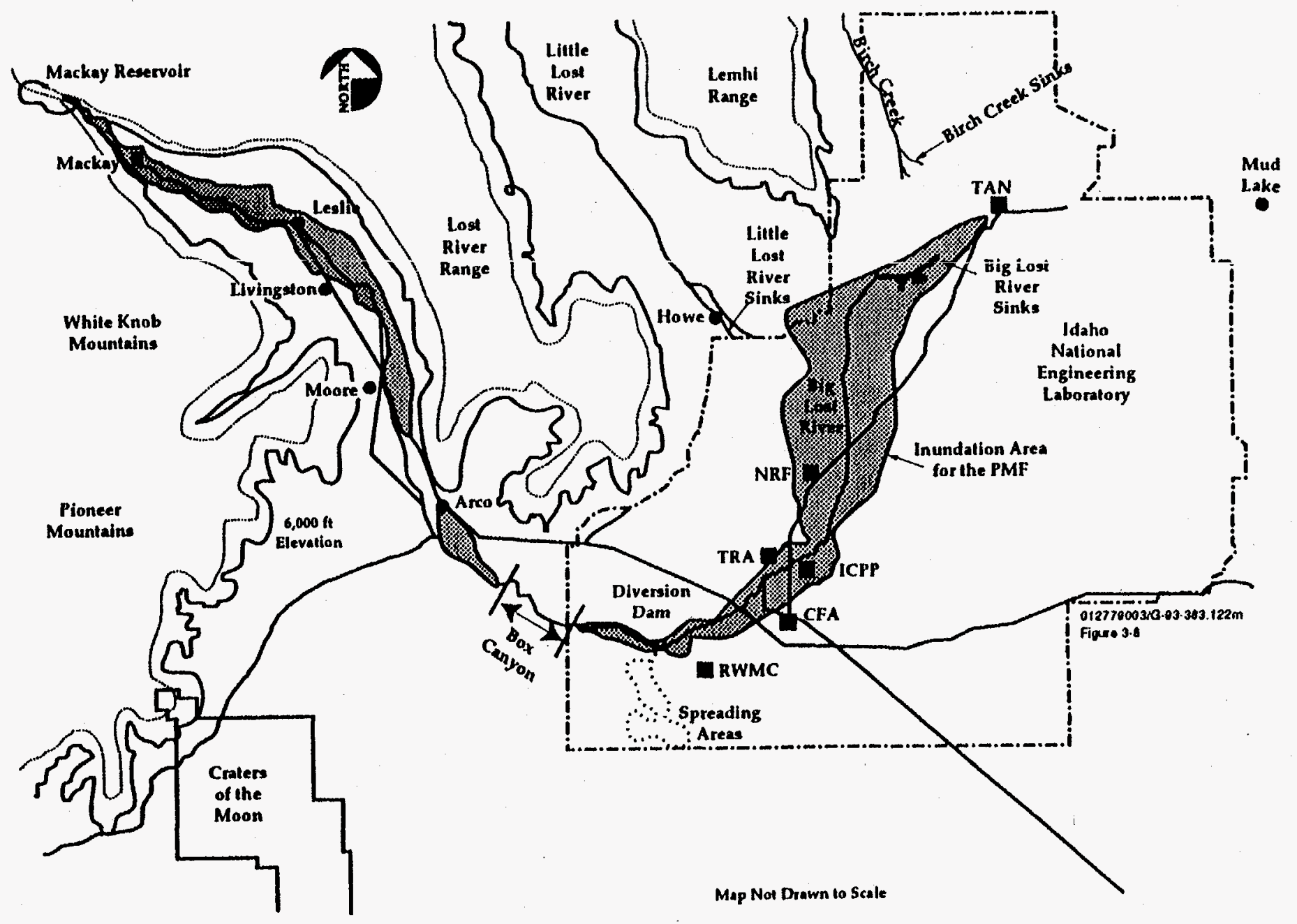

Figure 1-17. Location of surface water features on or near the INEL and inundation map for the PMF-induced overtopping failure of Mackay Dam (Koslow and Van Haaften 1986). 
and 18 were partly filled with water. As a result, several actions were taken including dike repair, dike and drainage channel improvements, and procedural changes.

TAN was threatened by floodwaters in April 1969 when Birch Creek reached TAN. The Big Lost River also overflowed its sinks into the normally dry outlet channel that flows toward TAN. (The Big Lost River and Birch Creek sinks are shown in Figures 1-3 and 1-17.) In addition, the Little Lost River had started to fill its sink located near Howe, Idaho, just outside the INEL, and was spreading toward the Big Lost River channel. The principal source of water in these stream beds was local snowmelt on the alluvial fan at the mouth of Birch Creek.

Four weather phenomena were required to produce these spring 1969 runoff conditions: (a) heavy rainfall saturating the earth to an above-normal depth, (b) hard freezes extending the frostline to unusual depths, (c) a late spring followed by an abnormally long period of unusually high daily spring temperatures, and (d) heavy snow accumulation on the frozen ground. The probability of all four occurrences in a given year is very small.

The flood at TAN in 1969 originated primarily from the slopes near the Birch Creek sink. Thus, flood control measures consisting of low-level dikes, drainage or diversion ditches, emergency injection wells, and settling basins were initiated at TAN. The dike system is capable of storing about 13,000 acre-ft of water, which is more than three times the 3,800 acre-ft flood of 1969. Ditches channel the water into permeable areas and an existing gravel pit located about $1 \mathrm{mi}$ northwest of TAN.

As a result of the 1969 flood and previous smaller floods, flood-control measures were initiated at the INEL. A diversion dam was constructed for the Big Lost River at the southern end of the INEL (see Figure 1-17). The INEL Flood Diversion System (Bennett 1986) was upgraded to divert a 300-yr flood (previously it protected against a 55-yr flood).

A hydrological characterization of the Birch Creek basin indicated a low potential for flooding at TAN (Koslow 1984). The potential for flooding of Birch Creek was predicted to be low. Birch Creek discharges are characteristic of a stable stream fed by groundwater, with low flows of $2.1 \mathrm{~m}^{3} / \mathrm{s}\left(75 \mathrm{ft}^{3} / \mathrm{s}\right)$ and very consistent discharges. The predicted $100-\mathrm{yr}$ peak flow of $3.3 \mathrm{~m}^{3} / \mathrm{s}\left(116 \mathrm{ft}^{3} / \mathrm{s}\right)$ at $6.4 \mathrm{~km}(4 \mathrm{mi})$ upstream of the INEL northern boundary would not cause flooding at TAN. Downstream, Birch Creek flows are diverted for hydropower and irrigation with no flow onto the INEL during the irrigation season and minimal return flow onto the INEL during the winter months.

A study of the flooding records for the Little Lost River basin indicate that the Little Lost River basin has a 100-yr flood flow of $550 \mathrm{ft}^{3} / \mathrm{s}$ near Howe, Idaho. Based on observed infiltration rates in the area, calculations indicate that this flooding rate would require about $1-1 / 2 \mathrm{mi}^{2}$ to dissipate. Thus, the Little Lost River is not likely to reach the Big Lost River channel.

\subsubsection{Volcanism}

The information in this section was excerpted from an engineering design file compiled for the safety analysis report for TAN operations (Smith 1994). Related geologic information is contained in Section 1.4.3. 
1.5.4.1 Regional Volcanism. The eastern Snake River Plain is part of a $600-\mathrm{km}$ volcanic belt that extends from the Idaho-Oregon border to the Yellowstone Plateau. The INEL area has been the site of volcanism and dike intrusion for at least 10 million years. The early stage of regional volcanism, until about 4.3 nillion years ago, involved explosive eruptions of silicic pumice and associated caldera collapse. During the past 4 million years, however, volcanism on the eastern Snake River Plain has been predominantly basaltic, involving mild outpourings of fluid lava flows from fissure vents and from small shield volcanoes. Given the generally low topographic gradients (less than $3 \mathrm{~m} / \mathrm{mi}$ ), the low topographic relief (generally less than $100-\mathrm{m}$ elevation difference), and the low effusion rates of lavas in the INEL area, future lava flows are expected to move downslope at average velocities of less than about $1 \mathrm{~km} / \mathrm{hr}$. Lava flows on the eastern Snake River Plain seldom exceed $30 \mathrm{~km}$ in length and most extend less than $12 \mathrm{~km}$ from their source vents. The median thickness of lava flows in the INEL area is about $6 \mathrm{~m}$, and $80 \%$ of the flows are under $12 \mathrm{~m}$ in thickness.

Volcanic vents on the eastern Snake River Plain are not randomly distributed, but are concentrated with northwest-trending volcanic rift zones, several of which traverse the INEL area (see Figure 1-14). The volcanic rift zones are belts of basaltic shield volcanoes, fissure-fed lava flows, noneruptive tensional fissures, and small normal faults. The ground deformation features of eastern Snake River Plain volcanic rift zones (fissures, faults, and monoclinal flexures) are similar to those of other regions of basaltic volcanism, and result from basaltic dike emplacements beneath the rift zones. In addition to the volcanic rift zones, a broad, northeast-trending volcanic highland occupies the axis of the eastern Snake River Plain. Known as the axial volcanic zone, this area is occupied by basaltic shield volcanoes and scattered cinder cones. Its prominent features include five isolated landforms associated with the growth of rhyolitic domes at Big Southern Butte, Cedar Butte, Middle Butte, East Butte, and an unnamed dome near East Butte.

Future rhyolite-dome eruptions, such as those that occurred at Big Southern Butte (300,000 years ago) and Cedar Butte (430,000 years ago) are less probable than basaltic volcanism, because the geologic record shows that basaltic volcanism has been more frequent and more voluminous than rhyolitic volcanism in the area during the past several million years.

\subsubsection{Lightning}

Lightning at the INEL originaties from thunderstorms that pass across the Snake River Plain, predominantly during the summer months. A day on which thunder is heard is defined as a thunderstorm day by the National Weather Service. Lightning does not have to be seen, and rainfall or hail is not required. On the average, two or three thunderstorm days occur during each of the months from June through August (Clawson 1989). Thunderstorms may be accompanied by cloud-to-ground as well as cloud-to-cloud lightning.

The INEL is monitored by the U.S. Bureau of Land Management Interagency Fire Center lightning detection system. This system detects the location and number of lightning strikes for wild fire control. Although the number of lightning strikes on the INEL is not very high, the lack of natural targets and the poor conductivity of the lava rock and desert soil cause man-made structures to be susceptible to lightning strikes. 


\subsection{External Man-Made Threats}

External, man-made events that are potential accident initiators, as analyzed in Chapter 3, are identified in this section. These include fires, explosions, and transportation accidents.

\subsubsection{Fires}

Fires that could impact INEL activities are range fires and fires in co-located facilities. Ignition for such a fire could come from man, vehicles, lightning, spontaneous combustion, sunlight effects, failed electrical transmission lines or transformers, or other causes. 'An estimated 22 range fires required INEL Fire Department response between 1984 and 1994. ${ }^{\mathrm{a}}$ These involved burning of sagebrush on one or more acres of land. A recent range fire at INEL started on July 1, 1994, on U.S. Highway $20 / 26$ and progressed $21.7 \mathrm{~km}$ (13.5 mi) to the northeast, burning 20,400 acres. The fire came within $6.4 \mathrm{~km}$ (4 mi) of the TRA and $2.4 \mathrm{~km}(1.5 \mathrm{mi})$ of NRF.

\subsubsection{Explosions}

Explosion sources, such as propane and fuel tanks, hydrogen, and explosives would be identified and the threat from explosions evaluated as part of the hazard and accident analyses in Chapter 3.

\subsubsection{Transportation Accidents}

Transportation accidents that would be discussed here and evaluated in Chapter 3 include aviation accidents involving aircraft impact on plant structures and truck and railroad accidents based on the distance to the nearest public highway or active railroad line. Marine and pipeline accidents need not be evaluated because of the absence of large bodies of water and pipelines.

\subsection{Nearby Facilities}

This section identifies any nearby facilities that could be affected by accidents in the facility under evaluation or could adversely impact that facility. No industrial or military facilities are located closer to the INEL boundary than Idaho Falls, approximately $17 \mathrm{~km}(29 \mathrm{mi})$ from the eastern INEL boundary (WINCO 1993). However, INEL facilities and D\&D projects could be affected by or could affect an environmental remediation or D\&D project. The INEL has nine major facility areas: TAN, TRA, ICPP, CFA, PBF/ARA, EBR-I/BORAX, RWMC, NRF, and ANL-W (see Figure 1-1). Each of these facilities is designated as a WAG (FFA/CO 1991). The following sections contain brief descriptions of the INEL facility areas and those scheduled for decontamination and dismantlement (D\&D). More comprehensive information is provided in Chapter 2. Table 1-4 provides distances between INEL facilities. Postulated accidents at INEL

a. Private communication with M. Johnson, Battalion Chief, INEL Fire Department, June 7, 1994.

b. Private communication with M. Hunter, INEL Fire Department, August 15, 1994. 
Table 1-4. Distances between INEL facilitics (in miles).

\begin{tabular}{|c|c|c|c|c|c|c|c|c|c|c|c|c|c|c|}
\hline \multirow[b]{2}{*}{$\begin{array}{l}\text { Major INEL } \\
\text { facilities }\end{array}$} & \multicolumn{14}{|c|}{ ER WAGs } \\
\hline & $\begin{array}{l}\text { TAN/TSF } \\
\text { (WAG-1) }\end{array}$ & $\begin{array}{l}\text { TAN/IET } \\
\text { (WAG-1) }\end{array}$ & $\begin{array}{c}\text { TAN/LOFT } \\
(\text { WAG-1) }\end{array}$ & $\begin{array}{c}\text { TRA } \\
\text { (WAG-2) }\end{array}$ & $\begin{array}{c}\text { ICPP } \\
\text { (WAG-3) }\end{array}$ & $\begin{array}{c}\text { CFA } \\
\text { (WAG-4) }\end{array}$ & $\begin{array}{c}\text { PBF } \\
\text { control } \\
\text { (WAG-5) }\end{array}$ & $\begin{array}{c}\text { PBF } \\
\text { reactor } \\
(\text { WAG-5) }\end{array}$ & $\begin{array}{c}\text { ARA I \& } \\
\text { II } \\
\text { (WAG-5) }\end{array}$ & $\begin{array}{l}\text { ARA III } \\
\text { (WAG-5) }\end{array}$ & $\begin{array}{l}\text { ARA IV } \\
\text { (WAG-5) }\end{array}$ & $\begin{array}{c}\text { EBR 1 } \\
\text { (WAG-6) }\end{array}$ & $\begin{array}{l}\text { BORAX-V } \\
\text { (WAG-6) }\end{array}$ & $\begin{array}{l}\text { RWMC } \\
\text { (WAG-7) }\end{array}$ \\
\hline $\begin{array}{l}\text { TAN/TSF } \\
\text { (WAG-1) }\end{array}$ & $\mathbf{x}$ & 1.4 & 1.8 & 25.3 & 24.4 & 27.0 & 32.5 & 33.1 & 34.2 & 34.1 & 34.0 & 30.2 & 31.1 & 33.0 \\
\hline $\begin{array}{l}\text { TAN/IET } \\
\text { (WAG-1) }\end{array}$ & 1.4 & $\mathbf{x}$ & 3.2 & 26.7 & 25.8 & 28.4 & 33.9 & 34.5 & 35.6 & 35.5 & 35.9 & 32.2 & 32.5 & 34.4 \\
\hline $\begin{array}{l}\text { TAN/LOFT } \\
\text { (WAG-1) }\end{array}$ & 1.8 & 3.2 & $\mathbf{x}$ & 26.1 & 26.2 & 28.8 & 34.3 & 34.9 & 36.0 & 35.8 & 36.3 & 32.6 & 32.9 & 34.3 \\
\hline TRA (WAG-2) & 25.3 & 26.7 & 26.1 & $\mathrm{X}$ & 2.3 & 4.9 & 10.4 & 11.0 & 12.1 & 12.0 & 12.4 & 7.7 & 9.0 & 10.9 \\
\hline ICPP (WAG-3) & 24.4 & 25.8 & 26.2 & 2.3 & $\mathbf{x}$ & 3.4 & 8.9 & 9.5 & 10.6 & 7.4 & 10.9 & 7.2 & 7.5 & 9.4 \\
\hline CFA (WAG-4) & 27.0 & 28.4 & 28.8 & 4.9 & 3.4 & $\mathbf{x}$ & 5.8 & 6.4 & 7.5 & 7.4 & 7.8 & 4.8 & 5.1 & 6.0 \\
\hline $\begin{array}{l}\text { PBF control } \\
\text { (WAG-5) }\end{array}$ & 32.5 & 33.9 & 34.3 & 10.0 & 8.9 & 5.8 & $\mathrm{x}$ & 0.6 & 4.3 & 3.3 & 3.5 & 10.3 & 10.6 & 11.8 \\
\hline $\begin{array}{l}\text { PBF reactor } \\
\text { (WAG-5) }\end{array}$ & 33.1 & 34.5 & 34.9 & 10.4 & 9.5 & 6.4 & 0.6 & $\mathbf{x}$ & 4.9 & 3.9 & 4.1 & 10.9 & 11.2 & 12.4 \\
\hline $\begin{array}{l}\text { ARA I \& II } \\
\text { (WAG-5) }\end{array}$ & 34.2 & 35.6 & 36.0 & 11.0 & 10.6 & 7.5 & 4.3 & 4.9 & $\mathbf{x}$ & 1.0 & 1.5 & 11.8 & 12.8 & 13.5 \\
\hline $\begin{array}{l}\text { ARA III } \\
\text { (WAG-5) }\end{array}$ & 34.1 & 35.5 & 35.8 & 12.0 & 7.4 & 7.4 & 3.3 & 3.9 & 1.0 & $\mathbf{x}$ & 0.6 & 12.7 & 13.0 & 15.5 \\
\hline $\begin{array}{l}\text { ARA IV } \\
\text { (WAG-5) }\end{array}$ & 34.0 & 35.9 & 36.3 & 12.4 & 10.9 & 7.8 & 3.5 & 4.1 & 1.5 & 0.6 & $\mathrm{x}$ & 13.3 & 12.3 & 13.6 \\
\hline EBR I (WAG-6) & 30.2 & 32.2 & 32.6 & 7.7 & 7.2 & 4.8 & 10.3 & 10.9 & 11.8 & 12.7 & 13.3 & $\mathbf{x}$ & 0.5 & 1.5 \\
\hline $\begin{array}{l}\text { BORAX-V } \\
\text { (WAG-6) }\end{array}$ & 31.1 & 32.5 & 32.9 & 9.0 & 7.5 & 5.1 & 10.6 & 11.2 & 12.8 & 13.0 & 12.3 & 0.5 & $\mathbf{x}$ & 0.9 \\
\hline $\begin{array}{l}\text { RWMC } \\
\text { (WAG-7) }\end{array}$ & 33.0 & 34.4 & $\mathbf{3 4 . 3}$ & 10.9 & 9.4 & 6.0 & 11.8 & 12.4 & 13.5 & 15.5 & 13.6 & 1.5 & 0.9 & $\mathbf{x}$ \\
\hline NRF (WAG-8) & 20.7 & 22.1 & 22.5 & 7.0 & 6.1 & 8.7 & 14.2 & 14.8 & 15.9 & 15.8 & 16.2 & 11.5 & 12.8 & 14.7 \\
\hline $\begin{array}{l}\text { ANL-W } \\
\text { (WAG-9) }\end{array}$ & 46.9 & 48.3 & 48.7 & 24.8 & 23.3 & 16.0 & 20.8 & 21.4 & 14.0 & 14.9 & 15.5 & 24.4 & 24.7 & 26.2 \\
\hline
\end{tabular}


facilities could result in a release of radioactive and/or non-radioactive (hazardous) materials requiring evacuation of environmental remediation and D\&D sites. Evacuation procedures are covered by the INEL emergency management program as discussed in Chapter 15.

\subsubsection{TAN-WAG-1}

The TAN WAG-1 is located in the north-central portion of the INEL, near the west boundary of Jefferson County, along State Highway 33. TAN was originally established to house a project to develop nuclear-powered aircraft (Aircraft Nuclear Propulsion Project) which was operated from 1951 to 1961 . The area later was used in reactor accident testing (Loss-of-Fluid Test [LOFT] Facility) and to perform flow tests to support reactor safety studies (Semiscale Facility). Currently, TAN facilities are used to handle and evaluate irradiated material and to support energy research and defense programs.

TAN is about 2,121 acres in size. The facility area encompasses the following four subareas: the Initial Engine Test (IET) Facility; the Technical Support Facility; the Water Reactor Research Test Facility; and the Containment Test Facility. TAN is approximately $6.1 \mathrm{mi}$ from the northwestern INEL boundary.

\subsubsection{TRA-WAG-2}

The TRA is located in the southern portion of the INEL in Butte County west of the ICPP and north of the CFA. TRA is about 747 acres in size. TRA is approximately $6.6 \mathrm{mi}$ from the northwestern INEL boundary.

TRA houses extensive facilities for studying effects of radiation on materials and fuels. When the area was established in the early 1950 s, three reactors were built: the Materials Test Reactor (shut down in 1970); the Engineering Test Reactor (completed in 1957 and inactive since 1981); and the Advanced Test Reactor (completed in 1965 and operated since 1967). The Materials Test Reactor and the Engineering Test Reactor are identified for D\&D. The Advanced Test Reactor is used for materials testing under reactor conditions and for producing radioisotopes used in medicine, research, and industry. Numerous laboratory facilities dedicated to chemical science and physics programs are located at the TRA. For research and testing, a hot cell operation is maintained in support of these and other facilities.

\subsubsection{ICPP-WAG-3}

The ICPP is located in the south-central portion of the INEL in Butte County between TRA and PBF/ARA, and just south of the Big Lost River. The ICPP is about 510 acres in size. ICPP is approximately $8.5 \mathrm{mi}$ from the southern INEL boundary.

The ICPP was a one-of-a-kind facility built in the early 1950s for reprocessing governmentowned nuclear fuels from research and defense (primarily Naval) reactors. The ICPP recovered uranium from the spent nuclear fuels for reuse. The ICPP mission now includes the following:

- Developing advanced technologies to process spent nuclear fuel for permanent offsite disposition and to achieve waste minimization 
- Receiving, storing, and processing Navy and other DOE-spent nuclear fuels.

\subsubsection{CFA-WAG-4}

The CFA is located in the south central region of the INEL, south of the ICPP, near United States Highways 20 and 26 in Butte County. CFA is about 1,372 acres in size and is approximately $5.6 \mathrm{mi}$ from the southern INEL boundary. The original facilities at CFA were built in the 1940s and 1950s. Many technical and support services for the entire site are provided from CFA including solid waste disposal, environmental monitoring and calibration laboratories, communication systems, security, fire protection, medical services, warehouse, cafeteria, vehicle and equipment pools, and bus operations. Waste operations facilities include the Hazardous Waste Storage Facility and the Solid Waste Landfill. The Hazardous Waste Storage Facility temporarily houses hazardous wastes pending shipment to a commercial, offsite, EPA-permitted disposal site.

\subsubsection{PBF/ARA-WAG-5}

The PBF/ARA is located in the south portion of the INEL in Butte and Bingham Counties. PBF/ARA is about 1,388 acres in size. PBF/ARA is approximately $6.4 \mathrm{mi}$ from the southern INEL boundary.

Originally, the PBF area was built for Special Power Excursion Reactor Tests (SPERT) which began in the late 1950s and concluded in 1970. Following the end of SPERT, PBF operations were initiated in 1972 . For approximately 10 years, PBF served as the severe-damage testing facility for nuclear fuels and materials used in commercial reactors. The reactor support facilities were converted to waste management-related uses, including the development of radioactive waste volume reduction techniques and waste immobilization research. One former reactor building houses the Waste Experimental Reduction Facility (WERF), where low-level waste and mixed waste are treated for volume reduction and removal of hazardous components. Other facilities in the area include the Mixed Waste Storage Facility, WERF Waste Storage Building, and the Waste Engineering Development Facility.

The ARA was constructed in 1957 to conduct tests of portable power reactors for the United States Army. The program was discontinued and all reactors were removed and dismantled. ARA I (hot cell), ARA II [site of the stationary Low Power Reactor No. 1 (SL-1) accident in 1961], and ARA III (reactor test pit) are identified for D\&D. ARA IV presently is used to perform explosive-initiated, powered-metal, manufacturing experiments.

\subsubsection{EBR-1/BORAX-WAG-6}

The EBR-I and BORAX compose WAG-6. WAG-6 is located south of United States Highway 20 in Butte County. It is about 36 acres in size. EBR-I/BORAX is approximately $4.5 \mathrm{mi}$ from the southern INEL boundary.

In 1961, EBR-I became the first reactor in the world to generate usable amounts of electricity. Today, this site is a National Historic Landmark, usually open daily to the general public from Memorial Day through Labor Day. 
BORAX is near EBR-I. This area originally included five separate experimental reactors that operated between 1953 and 1964. The facilities were not used after 1964. D\&D is completed or scheduled for BORAX facilities.

\subsubsection{RWMC-WAG-7}

The RWMC is located at the far southwest corner of the INEL, southwest of EBR-I/BORAX and east of the Big Lost River. The RWMC is about 815 acres in size and is approximately $3.5 \mathrm{mi}$ from the southern INEL boundary.

Various strategies for. waste storage, processing, and disposal are investigated at the RWMC. The complex was established in 1952 as a controlled area for the disposal of solid radioactive wastes generated at the INEL. The area was used to store defense wastes after 1970. Currently, the facility provides for interim storage of transuranic (TRU) waste and disposal of low-level radioactive waste. RWMC supports research and development projects to improve treatment and TRU waste interim storage; low-level radioactive waste disposal; buried waste remediation technologies; and environmental restoration.

There are two main operating areas within the complex: the TRU waste storage area and the subsurface disposal area. In the storage area, TRU waste is managed, including interim storage operations, certification, technology development, and preparation for future shipment to the Waste Isolation Pilot Plant in New Mexico. A new engineered storage area that meets Resource Conservation and Recovery Act requirements is under construction for waste stored on two asphalt pads currently covered by air-support structures. The subsurface disposal area is dedicated to permanent disposal of low-level radioactive waste generated at the INEL. Related research and development projects support buried waste, remediation technologies, and contaminant migration studies.

\subsubsection{NRF-WAG-8}

The NRF houses prototype reactors which are operated for reactor plant development and training of naval officers and enlisted personnel. The NRF also supports research and development efforts on reactor materials by preparation and examination of irradiation test specimens and by examination of expended fuel from naval reactors. Many NRF reactor facilities are in shutdown mode and are being prepared for decommissioning. The NRF site is approximately 4480 acres in area.

\subsubsection{ANL-W-WAG-9}

The ANL-W is the most eastern of the INEL facilities. It is located approximately $26 \mathrm{~km}$ (16 mi) northeast of CFA. ANL-W is operated by the University of Chicago for the U.S. Department of Energy Chicago Operations Office. ANL-W has administrative control over an area of approximately 360 ha ( 890 acres) in the southeastern corner of the INEL, while the facilities themselves cover less than 24 ha (60 acres).

The ANL-W facility was constructed for the purpose of researching and developing liquid metal fast breeder reactor technology. ANL-W has been at the INEL since its inception as the 
NRTS, where it originally built and operated the EBR-I facility. It houses the EBR-II, the first pool-type liquid-metal reactor. In addition to EBR-II, the ANL-W complex has four other reactors and two fuel examination facilities. EBR-II was placed in shutdown mode in 1994 and is currently being de-fueled and placed in an industrial condition for later decommissioning.

\subsubsection{WAG-10}

The Snake River Plain Aquifer and operable units representing a variety of small sites and facilities not encompassed in other WAGs are identified collectively as WAG-10 (EG\&G 1993). Facilities identified as part of WAG-10 include the Liquid Corrosive Chemical Disposal Area (LCCDA); Old Disposal Pit; LCCDA Limestone Treatment and Disposal Pit; Organic Moderated Reactor Experiment Leach Pond; and a former bombing range. The majority of the sites are centrally located on the INEL site with the bombing range representing approximately $30 \%$ of the INEL surface area. WAG-10 is about 170,880 acres in size.

\subsubsection{INEL D\&D Surplus Facilities}

INEL surplus radioactively contaminated facilities are listed in Table 1-5 (Buckland 1993).

\subsection{Validity of Existing Environmental Analyses}

Site characteristic assumptions for the INEL have remained essentially the same with the exception of public and worker populations for the past several years. Therefore, there are no significant discrepancies between Baseline Safety Analysis File and draft environmental analyses and impact statements that have recently been developed. 
Table 1-5. INEL D\&D surplus facility list.

\begin{tabular}{ll}
\hline \multicolumn{1}{c}{ Location } & \multicolumn{1}{c}{ Facility } \\
\hline TAN & LOFT Ancillaries-Mobile Test Assembly \\
TRA & Technical Support Facility \\
& Engineering Test Reactor \\
& Materials Test Reactor \\
& Test Train Assembly Facility \\
Army Re-entry Vehicle Facility Site & ARVFS \\
(ARVFS) & \\
ICPP & Service Waste Diversion Facility \\
& Fuel Receipt and Storage Facility \\
& Fuel Processing Building \\
& Headend Processing Plant \\
& High Level Waste Tank Farm \\
& Stored Fuel Exterior \\
& Waste Calcine Facility \\
PBF/ARA & ARA I, II, III \\
EBR-1/BORAX & BORAX-V Facility \\
\hline
\end{tabular}




\subsection{References}

Bennett, C.M. (1986), Capacity of the Diversion Channel Below the Flood Control Dam on the Big Lost River at the Idaho National Engineering Laboratory, U.S. Geological Survey Water-Resources Investigation Report 86-4204, DOE-ID-22071, p. 2.

Bennett, C.M. (1990), Streamflow Losses and Ground Water Level Charges Along the Big Lost River at the Idaho National Engineering Laboratory, Idaho, U.S. Geological Survey Water Resources Investigation Report, 90-4067, DOE-ID-22091, p. 49.

Bowman, A. L., W. F. Downs, K. S. Moor, and B. F. Russell (1985), INEL Environmental Characterization Report, Volume I: Summary, EGG-NPR-6688, EG\&G Idaho, Inc., September 1984, revised January 1985.

Buckland, R. J., D. J. Kenoyer, D. H. Preussner, (Buckland 1993), INEL D\&D Long-Range Plan, EGG-WM-10924, October 1993. (Rev 10 to be published in September 1995.)

Bureau of the Census (1992), 1990 Census of Population and Housing, U.S. Government Printing Office, Washington, D.C.

Clawson, K.L., G.E. Start, and N.R. Ricks (Clawson 1989), Climatography of the Idaho National Engineering Laboratory, DOE-ID-12118, 2nd Edition, December.

Coats, D. W. and R. C. Murray (1985), Natural Phenomena Hazards Modeling Project: Extreme Wind/Tornado Hazard' Models for Department of Energy Sites, UCRL-53526, Revision 1, Lawrence Livermore National Laboratory, University of California, August 1985.

Department of Energy (DOE 1989), The Idaho Department of Fish and Game and the U.S. DOE, Authorization and Agreement to Permit Hunting upon INEL, Idaho Operations Office, Idaho Falls, Idaho.

Doser, D. I. (1985), "Source Parameters and Faulting Processes of the 1959 Hebgen Lake, Montana, Earthquake Sequence," Joumal of Geophysical Research, Vol. 90, No. B6, May 10, 1985.

EG\&G Idaho, Inc. (1990), Idaho National Engineering Laboratory Environmental Resources, EG\&G, Idaho Falls, ID.

Einerson, J. J. (1994), Air Dispersion Parameters for Use in Idaho National Engineering Laboratory Department of Energy Safety Analyses, EGG-WM-11243, Revision 1, EG\&G Idaho, Inc., August 1994.

Federal Register (Fed Reg 1991), 56 FR 194, "Sole Source Designation of the Eastern Snake River Plain Aquifer, Southern Idaho; Final Determination," U.S. Environment Protection Agency, October 7, 1991. 
Garabedian, S.P. (1986), Application of a Parameter Estimation Technique to Modeling the Regional Aquifer Underlying the Eastern Snake River Plain, Idaho, U.S. Geological Survey, Water Supply Paper 2278, p. 60.

Gorman, V. W. and R. C. Guenzler, The 1983 Borah Peak Earthquake and INEL Structural Performance, EGG-EA-6501, EG\&G Idaho, Inc., December 1983.

Jackson, S. M. (1985), "Acceleration Data from the 1983 Borah Peak, Idaho Earthquake Recorded at the Idaho National Engineering Laboratory", Workshop XXVIII on the Borah Peak, Idaho Earthquake, U.S. Geological Survey Open File Report 85-290, 1985.

Jackson, S. M., I. G. Wong, G. S. Carpenter, D. M. Anderson, and S. M Martin (1993), "Contemporary Seismicity in the Eastern Snake River Plain, Idaho Based on Microearthquake Monitoring", Bulletin of the Seismological Society of America, Vol. 83. No. 3, June 1993.

Kaminsky, J. F., K. N. Keck, A. L. Schafer-Perini, C. F. Hersley, R. P. Smith, G. J. Stormberg, and A. H. Wylie (1994), Remedial Investigation Final Report with Addenda for the Test Area North Groundwater Operable Unit 1-07B at the Idaho National Engineering Laboratory, Volume I, EGG-ER-10643, Revision 0, EG\&G Idaho, Inc., January 1994.

Koslow, K. N. (1984), Hydrological Characterization of Birch Creek Basin, EGG-PBS-6782, EG\&G Idaho, Inc., December 1984.

Koslow, K. N. and D. H. Van Haaften (1986), Flood Routing Analysis for a Failure of Mackay Dam, EGG-EP-7184, EG\&G Idaho, Inc., June 1986.

Kuntz, M. A. (1992), "A model-based perspective of basaltic volcanism on the eastern Snake River Plain, Idaho," Geological Society of America, Memoir 179, 1992.

Kuntz, M.A., H.R. Covington, and L.J. Schorr (1992), "An Overview of Basaltic Volcanism of the Eastern Snake River Plain, Idaho," in Regional Geology of Eastern Idaho and Western Wyoming, P.K. Link, M.A. Kuntz, and L.B. Platt, editors, Geological Society of America Memoir 179, pp. 227-267.

McKinney, J.P. (1985), Big Lost River 1983-1984 Flood Threat, EG\&G Idaho, Inc., Idaho Falls, ID.

Mundorff, M. J., E. G. Grosthwaite, and C. Kilburn (1964), Ground Water for Irrigation in the Snake River Basin in Idaho, Geological Survey Water-Supply Paper 1654, U.S. Geological Survey, 1964.

Oaks, S. D., Historical Seismicity Investigation for the November 11, 1905 Earthquake, EGG-GEO10203, EG\&G Idaho, Inc., March 1992.

Pierce, K. L. and L. A. Morgan (1992), "The track of the Yellowstone hot spot: Volcanism, faulting, and uplift," Geological Society of America, Memoir 179, 1992. 
Pittman, J.R., R.G. Jensen, and P.F. Fischer (1988), Hydro-geologic Conditions at the Idaho National Engineering Laboratory 1982-1985, U.S. Geological Survey Water-Resources Investigation Report 89-4008, DOE-ID-22078.

Robertson, J. B., R. Schoen, and J. T. Barraclough, The Influence of Liquid Waste Disposal on the Geochemistry of Water at the National Reactor Testing Station, Idaho: 1952-1970, U.S. Geological Survey, Water Resources Division, USGS Open-File Report IDO-22053, February 1974.

Scott, W.E. (1982), Surficial Geologic Map of the Eastern Snake River Plain and Adjacent Areas, Idaho and Wyoming, U.S. Geclogical Survey Miscellaneous Investigation Map I-1372, scale $1: 250,000$.

Smith, R. P. (1994), Potential Impacts of Selected Magmatic Processes at Test Area North, EDFTANO-94-23, engineering design file, EG\&G Idaho, Inc., May 25, 1994.

Smith, R. B. and W. J. Arabasz (1991), "Seismicity of the Intermountain Seismic Belt," in Neotectonics of North America; Geology of North America, Boulder, Colorado, 1991.

State of Idaho, Department of Health \& Welfare, U.S. Environmental Protection Agency, Region 10, U.S. Department of Energy (FFA/C), 1991), Federal Facility Agreement and Consent Order, December 4, 1991.

Stickney, M. C. and M. J. Bartholomew (1987), "Seismicity and Late Quaternary Faulting of the Northern Basin and Range Province, Montana and Idaho," Bulletin of the Seismological Society of America, Vol. 77, October 1987.

"Uniform Building Code," (UBC 1985), International Conference of Building Inspectors, 1985.

Wenzel, D. R. (1994), The Radiological Safety Analysis Computer Program (RSAC-5), WINCO-1123, Westinghouse Idaho Nuclear Company, February 1994.

Westinghouse Idaho Nuclear Company (WINCO 1993), Idaho Chemical Processing Plant Safety Document, Section 3, "Site Characteristics," WIN-354-3.

Wood, W.W. and W.H. Low (1986), "Aqueous Geochemistry and Digenesis in the Eastern Snake River Plain Aquifer System, Iclaho," Geological Society of America Bulletin, 97 (12), pp. 14561466.

Wood, W.W. and W.H. Low (1988), Solute Geochemistry of the Snake River Plain Regional Aquifer System, Idaho and Eastern Oregon, U.S. Geologic Survey 1408.D.

Woodward-Clyde Consultants (1992), Earthquake Ground Motion Evaluations for the Proposed New Production Reactor at the Idaho National Engineering Laboratory, Volume I:

Deterministic Evaluation, and Volume II: Probabilistic Evaluation, EGG-GEO-10304, EG\&G Idaho, Inc., June 1992. 


\section{FACILITY DESCRIPTION}

\subsection{Introduction}

The environmental restoration (ER) program is a top-priority U.S. Department of Energy (DOE) mission at the Idaho National Engineering Laboratory (INEL). The goal of ER program activities is to undertake as necessary remedial actions at potential release sites at the INEL to protect the health of INEL personnel, the public, and the environment. Historically, research and development projects at the INEL have generated radioactive and chemical wastes. Some of these wastes have migrated into the environment and caused contamination at different sites around the INEL.

The INEL ER program activities include two major elements: environmental remediation and Decontamination and Dismantlement (D\&D). The environmental remediation program follows requirements set forth in the Comprehensive Environmental Response, Compensation, and Liability Act (CERCLA) and the INEL Federal Facility Agreement and Consent Order (FFA/CO). Environmental remediation activities are designed to assess and clean up potential release sites at the INEL. The D\&D program is responsible for managing radiologically contaminated surplus facilities to ensure that releases and exposures are acceptably controlled and to ultimately allow other use of the facilities or occupation of the land. The D\&D process follows the requirements in Chapter V of DOE Order 5820.2A, "Radioactive Waste Management," 1988.

This chapter provides a general description of the environmental remediation program and INEL Waste Area Groups (WAGs) and operable units (OUs); the D\&D program and current $D \& D$ projects; and environmental remediation and $D \& D$ techniques that may be used. Included is the identification of structures, systems, and components that may be important to safety and potential supporting facilities, services, and utilities for INEL ER program activities. Activityspecific safety analysis documentation will provide the necessary detailed description of the activity facilities and operation to support the activity-specific safety analysis.

\subsection{Requirements}

The following Codes of Federal Regulations, DOE orders, and other requirements are applicable to this chapter. These requirements are implemented by Lockheed Idaho Technologies Company (LITCO) manuals and procedures as indicated throughout the chapter.

- 10 CFR 300, "National Oil and Hazardous Substances Pollution Contingency Plan"a

- . 10 CFR 830.120, "Quality Assurance"

- $\quad 10$ CFR 835, "Occupational Radiation Protection"

- $\quad 40$ CFR 260, "Hazardous Waste Management Systems: General"

a. Limited to nuclear activities only. 
- $\quad 40$ CFR 280, "Technical Standards and Corrective Action Requirements for Owners and Operators of Underground Storage Tanks (UST)"

- DOE Order 5400.5, "Radiation Protection of the Public and the Environment," January 7, 1993

- DOE Order 5480.11, "Radiation Protection for Occupational Workers," December 21, 1988

- $\quad$ DOE Order 5480.23, "Nuclear Safety Analysis Reports," April 30, 1992

- DOE Order 5700.6C, "Quality Assurance," August 21, 1991

- $\quad$ DOE Order 5820.2A, "Radioactive Waste Management," September 26, 1988

- DOE Order 6430.1A, "General Design Criteria," April 6, 1989

- 42 U.S.C. 9605, "Comprehensive Environmental Response, Compensation, and Liability Act."

\subsection{Facility Overview}

The following sections provide a general description of the INEL WAGs and OUs, and the D\&D program.

\subsubsection{Environmental Remediation}

Since 1986, over 368 suspected release sites have been identified for investigation at the INEL. Initial investigation of potential release sites was conducted under the Resource Conservation and Recovery Act (RCRA)-based Consent Order and Compliance Agreement (COCA) (INEL 1987). This was later superseded by the CERCLA-based FFA/CO (INEL 1991a) described in Section 2.3.1.1. Potential release sites are grouped together for assessment and cleanup activities to provide greater management and cleanup efficiency. These groupings are called OUs. OUs are further grouped into ten WAGs, which generally correspond to the INEL functional areas. For each WAG, environmental remediation activities include an assessment phase to characterize the nature and extent of contamination and a cleanup/remediation phase (including implementation of interim and final remedial actions). When the extent and nature of contamination constitutes a potential threat to human health and safety or the environment, the latter cleanup or remediation phase is implemented. Sources of contamination include spills, abandoned tanks, septic systems, percolation ponds, landfills, and injection wells. Release sites range in size from large facilities such as the Subsurface Disposal Area (SDA) (pits and trenches) at the Radioactive Waste Management Complex (RWMC) to areas with no physical evidence of a release. Section 2.3.1.2 provides a summary description of each of the OUs contained within each WAG. 
2.3.1.1 Federal Facility Agreement and Consent Order. The INEL environmental remediation process, conducted under the CERCLA-based Federal Facility Agreement and Consent Order (FFA/CO), focuses on early determination of what should be done with each OU. The goal of the environmental remediation process is to ensure that releases or threatened releases of hazardous substances at the INEL are thoroughly investigated and that appropriate response actions are undertaken and completed as necessary to protect human health and the environment. One of the purposes of the FFA/CO is to establish a procedural framework and schedule for developing, prioritizing, implementing, and monitoring appropriate response actions at the INEL in accordance with CERCLA, the RCRA, and the Idaho Hazardous Waste Management Act.

Implementation of the FFA/CO is accomplished by the Action Plan For Implementation of the Federal Facility Agreement And Consent Order (INEL 1991b). The Action Plan describes how the environmental remediation program will proceed to ensure compliance with CERCLA and other applicable statutes. The Action Plan describes the application of the CERCLA process, as defined in the National Contingency Plan, to the remedial effort at the INEL. To ensure that actions are taken as soon as possible, OUs are addressed on two "tracks." OUs on Track 1 can be evaluated using existing data, while OUs on Track 2 require that additional field data be collected before a sound evaluation can be made. The determination may be that no further action is necessary.

The CERCLA process involves an initial investigation to determine the extent of contamination and available remediation alternatives, usually referred to as a Remedial Investigation/Feasibility Study (RI/FS). The RI/FS process could include preparation of a risk assessment to determine the level of risk associated with the characteristics of the site and the type, concentration, and amount of contamination. Following the RI/FS is the decision and agreement on the selection of a rennediation alternative formalized by a Record of Decision, and then the Remedial Design/Remedial Action phase in which the site is remediated. The Remedial Design encompasses plans and specifications for remedial action including design analysis, an operation and maintenance plan, a Quality Assurance Project Plan, a Health and Safety Plan, and the results of additional studies such as a safety analysis.

2.3.1.2 WAG and OU Descriptions. The following subsections summarize WAG and OU descriptions at the INEL (DOE-ID 1993). The summaries are presented by WAG and by OUs within each WAG. General information on the contamination for each OU can be found in the Auditable Safety Analysis for Environmental Restoration Activities at the INEL (INEL 1995). WAGs 8 and 9 are not within the scope of this Baseline Safety Analysis File (BSAF) and, therefore, are not included.

The location of each WAG is described in Chapter 1. A detailed site remediation layout is required in the Health and Safety Flan and is discussed in Chapters 9 and 10. Estimated inventories of radioactive and hazardous materials are contained in the referenced documents WINCO (1993) for WAG 3 and EG\&G (1993c) for the other WAGs. Estimated quantities of radioactive and hazardous waste generated from remediation activities are contained in EG\&G (1993a). 
2.3.1.2.1 WAG 1-Test Area North (TAN)-TAN is located in the northern portion of the INEL approximately $44 \mathrm{~km}$ (27 mi) northeast of the Central Facilities Area (CFA) (see Figure 1-1). TAN was originally established in the 1950s to support the U.S. Air Force Aircraft Nuclear Propulsion (ANP) Program. TAN encompasses the following subareas:

- Technical Support Facility (TSF) consists of facilities for handling, storage, examination, and research and development of spent nuclear fuel.

- Water Reactor Research Test Facility (WRRTF) consists of two buildings southeast of TSF that have housed several nonnuclear tests, mostly for simulating and testing water systems used in reactors.

- Containment Test Facility (CTF) and Specific Manufacturing Capability (SMC) Facility are contiguous facilities west of TSF that consist of structures built for those two operations and old buildings from the former ANP Program. CTF was constructed for nuclear reactor testing and was decommissioned. SMC is an active facility manufacturing components for a U.S. Department of Defense nonnuclear weapons system.

- Initial Engine Test (IET) Facility is an abandoned facility north of TSF that has numerous historical uses. IET was designed as a testing location for the nuclear jet engines developed under the former ANP Program in the 1950s and early 1960s.

The boundary of WAG 1 includes the fenced areas around TSF, WRRTF, CTF, SMC, and IET and areas outside the fences where operations associated with these subareas may have taken place. WAG 1 is divided into $10 \mathrm{OUs}$ with 83 sites consisting of approximately $1,230,000 \mathrm{yd}^{2}$ of potentially contaminated soil over 125 acres, including underground storage tanks (USTs), pits, ponds, and a railroad turntable. Hazardous, radioactive, and mixed wastes exist at WAG 1 . The following paragraphs briefly describe the WAG 1 OUs.

OU 1-01 includes two USTs (both have been removed) that contained foam stabilizer solutions for the fire protection system at Loss-of-Fluid Test Facility (LOFT) (site LOFT-07) and the IET (site IET-05), a diesel fuel UST (removed) (site TSF-01), a gravel pit where old sulfuric acid was dumped in the late 1950s (site TSF-04), a rubble pit that contained nonhazardous construction debris (site LOFT-03), three below-ground pits designed but never used to capture cryogenic waste materials (site LOFT-11), three clarifier pits (removed) (site TSF-11), and an injection well that handled process and sanitary waste from the IET (site IET-06). All have been investigated using a Track 1 and have been approved as sites that require no further action (NFA).

OU 1-02 includes 15 petroleum fuel or waste storage tanks [sites IET-01; LOFT-05 (two tanks), 06, 08, and 09; TSF-13, 14, 15, 24, 25, 32, and 33; WRRTF-09 and 10]. Thirteen tanks have been removed. Two other tanks have approved summary assessments, which recommend that these tanks be dropped from the combined COCA and FFA/CO list. Each site has been investigated using the Track 1 investigation and are classified as NFA sites. 
OU 1-03 consists of two burn pits (sites TSF-03 and WRRTF-01), a gasoline spill from the TSF service station (site TSF-02), and a bottle site where approximately 300 to 400 bottles were dumped. Soil in the pits is contaminated with metals and organics, resulting from trash and waste solvent burning that occurred through the mid 1960s. Both pits have been covered with soil. The sites have been investigated as part of a Track 2 . The burn pits and gasoline spill were determined to be NFA, and a removal action was recommended for the bottle site. The removal action was completed in July 1994 and all waste was removed. All sites in OU 1-03 are considered NFA.

OU 1-04 consists of a sump (TSF-12 TSF Acid Neutralization Sump), two ponds (sites LOFT-02 and TSF-29), three pits (sites TSF-17, TSF-20 and TSF-31), and a tank (site TSF-19). The areas were used for storage or disposal of acids or caustics. All of the sites were evaluated as part of a Track 2 and recommended for NFA, except TSF-29. Radioactive contaminants were detected that pose a risk greater than 1.0E-06. This site has been recommended for inclusion into the OU 1-10 RI/FS.

OU 1-05 includes nine radioactively contaminated sites: IET stack and rubble site (IET-04), IET hot waste tank (IET-07), TSF 'TAN/TSF-1 area (TSF-06), TSF intermediate level waste disposal system (TSF-09), TSF drainage pond (TSF-10), TSF contaminated tank SE of Tank V-3 (TSF-18), TSF IET valve pit (TSF-21), TSF PM-2A tanks (TSF-26) and WRRTF radioactive liquid waste tank (WRRTF-04). The bulk of the material requiring disposal may come from low levels of surface contamination in TSF-06, which is used as a common storage site for radioactively contaminated equipment. All of the sites have been evaluated as part of a Track 2 . Four sites (IET-04, IET-07, TSF-10 and WRRTF-04) have been recommended for NFA, the other sites were recommended for inclusion into the OU 1-10 RI/FS.

OU 1-06 consists of four old spill and disposal sites: a 5,000-gal diesel spill (site LOFT-01), a 10-gal sulfuric acid spill (site LOFT-10), a 1-gal mercury spill (site TSF-08), and a disposal pond for TSF sanitary and process wastes (site TSF-07). All of the sites have been evaluated as part of a Track 1 . The first two sites were recommended NFA. The mercury site was cleaned up using a removal action in June-November 1994 and considered NFA. The pond site has been recommended for inclusion into OU 1-10 RI/FS.

OU 1-07 includes the TSF-05 injection well at TAN-330 and groundwater contamination caused by the injection of wastewaters into the Snake River Plain Aquifer. The chosen treatment alternative for the TAN groundwater involves groundwater extraction (pumping), filtration, air stripping with vapor phase granular-activated carbon, and ion exchange. The pumped water will be treated using a filter to remove sediment; an air stripper to remove organic contaminants; and an ion exchange column to remove strontium. The ion exchange resin will be disposed as lowlevel radioactive waste. An Auditable Safety Analysis for Test Area North (TAN) Interim Action Groundwater Treatment Facility Operable Unit 1-07A, (MK-FIC 1993a) was prepared for this remediation activity. The interim action was started in February 1994 and has been moderately successful. The RI/FS for OU 1-07B has been completed and the remedial action will start when the Record of Decision is signed in 1995.

OU 1-08 includes a railroad turntable at TSF that is contaminated with mercury and diesel fuel (site TSF-22), the TSF sewage treatment plant and sludge drying beds contaminated with 
heavy metals (site TSF-28), an old injection well at WRRTF used for sanitary and process waste disposal (WRRTF-05), and a fuel oil leak (WRRTF-13). These sites are being evaluated in a Track 2 investigation that will be completed in June 1995.

OU 1-09 includes three disposal ponds at WRRTF (sites WRRTF-02, 03, and 06), a French drain (site TSF-36), and a well water spill (site TSF-37). WRRTF-06, WRRTF sewage lagoon, is still used to dispose of sanitary wastes; WRRTF-02 and -03 were used for process waste disposal. Hydrazine is the primary contaminant of concern for the WRRTF-03 pond. All the sites have been evaluated as part of a Track 1 . The three disposal ponds were recommended NFA. The French drain and well water spill were recommended for sampling in OU 1-08 Track 2.

OU-1-10 is the comprehensive RI/FS for WAG 1 that coordinates all cleanup work requiring characterization at the other WAG 1 OUs. This unit also includes a leach field where paint wastes, including solvents and heavy metals, were disposed. This unit will be investigated as part of the INEL site RI/FS OU 10-04 scheduled to start in March 1995.

2.3.1.2.2 WAG 2-Test Reactor Area (TRA)-TRA is in the southwest portion of INEL near the Big Lost River (Figure 2-1). It is located about $3 \mathrm{~km}$ (2 mi) northwest of the Idaho Chemical Processing Plant (ICPP), and $8 \mathrm{~km}(5 \mathrm{mi})$ northwest of CFA. TRA is a sophisticated materials testing complex that houses materials for studying the effects of radiation on materials, fuels, and equipment. The TRA includes three high-neutron flux test reactors: the Materials Test Reactor (MTR), the Engineering Test Reactor (ETR), and the Advanced Test Reactor (ATR). The ATR is eurrently the only operational reactor within TRA and is designed to produce a neutron flux that allows simulation of short-duration radiation effects on materials and fuels. The reactor produces isotopes used in medicine, research, and industry.

TRA covers approximately $0.3 \mathrm{~km}^{2}\left(0.1 \mathrm{mi}^{2}\right)$ and is surrounded by a security fence. Located outside the fence are parking areas, four waste disposal ponds, the sewage treatment plant, the ETR waste gas stack, the North Storage Area (NSA), and a helicopter landing pad. There are also unpaved roads, groundwater monitoring wells, and numerous construction rubble piles around the perimeter of TRA. Inside the fence are more than 73 buildings and 56 structures (Doornbos et al. 1991).

Forty-nine solid waste management units (SWMUs) have been identified at TRA under WAG 2 guidance and have been divided into 13 OUs. These SMWUs include a leaching pond, USTs, rubble piles, cooling towers, an injection well, French drains, and assorted spills where hazardous and/or mixed wastes exist. These sites include contamination from petroleum fuels, radioactive wastes, and hazardous and mixed wastes. The following paragraphs briefly describe the WAG-2 OUs.

OU 2-01 includes the Paint Shop Ditch (TRA-02), which is an open ditch near TRA-662 that was used for the disposal of paint shop wastes (paints, thinners, and spent solvents) until 1982. The site has been fully characterized and evaluated using the Track 1 process and a determination of NFA for the site was approved by DOE Idaho Operations Office (DOE-ID), the U.S. Environmental Protection Agency (EPA) and the State of Idaho in 1991. 
OU 2-02 includes five USTs that contained petroleum products. All five of the tanks have been removed from the ground and the initial site characterization found no or minimal contamination (which was removed) at the sites. The sites in this OU have been characterized and evaluated using the Track 1 process and have been classified and approved as NFA by DOE-ID, EPA, and the State of Idiaho.

OU 2-03 includes six miscellaneous spill sites: a pit used to dispose an acid spill residue; a French drain used to catch overflow runoff from a sulfuric acid tank; a site used to mix demineralizer brine; an acid pipe tunnel that received overflow from an acid pipe; the oil storage north area; and a fuel oil tank spill. All these sites were recommended for NFA after evaluation with a Track 2 process.

OU 2-04 includes eight sites of mainly petroleum products and polychlorinated biphenyl contamination. Three sites of polychlorinated biphenyl (PCB) contamination have been remediated to below 25 parts per million. TRA-34, the NSA, is being investigated and evaluated for remediation under the OU 10-06 radionuclide-contaminated RI/FS. The remaining sites [a contaminated area that resulted from spills off a former loading dock (TRA-722), diesel fuel contamination found in a well, and two areas of petroleum product soil contamination] have been recommended as NFA.

OU 2-05 includes several hot waste tanks used to store radioactive liquid waste from the MTR, ATR, and TRA laboratories. They have been evaluated for risk with a Track 2 process and have been recommended for NFA.

OU 2-06 is comprised of three rubble piles generated as a result of previous construction activities at TRA. All three sites have been determined to pose no unacceptable risk after evaluation under a Track 2 process and are recommended as NFA.

OU 2-07 consists of the ETR Basin, MTR areas, ATR cooling tower basins and cooling towers, and soil contaminated with chromium. It has been investigated using a Track 2 process and has been recommended as NFA.

OU 2-08 is the MTR canal in the basement of the MTR building used to store spent nuclear fuel elements. It was investigated under a Track 2 and is recommended as NFA.

OU 2-09 encompasses the TRA Sewage Treatment and Sludge Pit (TRA-07), the Final Sewage Leach Pond (TRA-13), and the Cold Waste Disposal Pond (TRA-08). The Sewage Treatment Plant, Sludge Pit, and Leach Ponds make up the Sewage Treatment Area. While the sewage treatment area was never intended for the disposal of hazardous or radioactive wastes, it is suspected that they both may contain either hazardous or radioactive wastes. Samples were collected from the area during the summer of 1992. A Track 2 summary report demonstrated that the risks resulting from this area are dominated by external exposure to ionizing radiation. After completion of the new treatment system, an action to reduce the external exposure risk from this site should be considered. This recommendation will be addressed in the WAG-2 comprehensive RI/FS. 
OU 2-10 includes the TRA Warm Waste Pond sediments interim action. The interim action was completed in May 1994. The Auditable Safety Analysis for Test Reactor Area Warm Waste Pond Interim Action Operable Unit 2-10 (MK-FIC 1993b) was used for the safety documentation during the interim action.

OU 2-11 is the rest of the units associated with the Warm Waste Pond OU, which are the retention basin (site TRA-04), leach pond (site TRA-03A), and the TRA disposal well, sampling pit, and sump (site TRA-05). Further evaluation of the shallow soils ( $0-10 \mathrm{ft}$ ) may be necessary in the retention basin area. This will be investigated further as part of OU 2-13 RI/FS.

OU 2-12 is comprised of the perched water zones underlying TRA. These zones are a result of water from the Cold Waste Pond, Warm Waste Pond, Chemical Waste Pond, and Sewage Lagoons infiltrating the ground and perching on low-permeability layers in the basalt. Long-term monitoring and reevaluation in 5 years was the recommended action. Sampling of several wells began in July 1993 and will continue for 3 years as part of the OU 2-13 RI/FS.

OU 2-13 is the comprehensive RI/FS for WAG 2, including the TRA chemical waste pond and will address sites not previously addressed and sites recommended for additional evaluation during the Track 2 process.

2.3.1.2.3 WAG 3-ICPP_WAG 3 consists of the area within the ICPP fence and adjacent areas where waste activities have taken place. Since 1950, the ICPP mission was the processing of spent nuclear fuel to recover reusable uranium and the management of high-level radioactive wastes. Byproducts of the processes were radioactive, hazardous, and mixed wastes including mixed fission products, heavy metals, and various solvents. Part of the current ICPP mission includes management of wastes and site environmental remediation.

WAG-3 is divided into 13 OUs. Cleanup sites include potential releases from hazardous materials such as hydrocarbons, stored in a tank farm and items associated with wastewater disposal systems (e.g., sumps, ponds, and an injection well). Possible contaminants include PCBs, solvents, metals, asbestos, acids, and radionuclides. The following paragraphs briefly describe each of the OUs.

OU 3-01 consists of four sites (CPP-49, 50, 51, and 61) suspected of PCB contamination. Less than 1 gal of liquid was estimated to have leaked from the CPP-705 and CPP-731 transformers (sites CPP-49 and 50 respectively). All four sites were approved for NFA after investigation under a Track 1.

OU 3-02 consists of sites possibly contaminated from hexane (sites CPP-63 and 64) and kerosene spills (site CPP-59), mercury contaminated areas (sites CPP-55 and 62), mercury from paint and paint solvent discharges (site CPP-53), contaminated paint chips and associated pad (site CPP-12), former paint shop (site CPP-60), an ICPP injection well that received wastes until 1984 (site CPP-23), ICPP Gravel Pits \#1 and \#2 (site CPP-37), a gas storage building (site CPP-18), fire training pits (site SPP-41), a solid waste storage bin (site CPP-21), a drum storage area (site CPP-54), soil contamination (site CPP-07) and a sulfuric acid spill (site CPP-57), sewage treatment plant lagoons (site CPP-65), a fly ash pit (site CPP-66), and an abandoned gasoline 
tank (site CPP-68). All were investigated using a Track 1. Sites CPP-23, 37, 59, 65, and 66 will be investigated further under OU 3-13 RI/FS. The others have been approved as NFA.

OU 3-03 consists of percolation ponds used for the discharge of ICPP service wastewater. This site was investigated under a Track 1 process and is recommended for further evaluation under OU 3-13 RI/FS.

OU 3-04 consists of the outsice walls and roofs of nine ICPP buildings with transite (containing asbestos) that has become partially friable. This OU was recommended and approved as NFA.

OU 3-05 consists of the old sewage treatment plant, and contains low-level radioactive and chemical contaminants. This OU is recommended for further evaluation under OU 3-13 RI/FS after being investigated under a Track 2 .

OU 3-06 consists of four sites where radiologically contaminated soil is known to exist. These sites include two sites with contaminated soil from the tank farm (CPP-33 and 34), a lime pit and French drain (site CPP-40), and a pilot plant storage area (site CPP-47). The sites have been investigated using a Track 1 . CPP -40 and 47 have been signed off as NFA, and the other two are being investigated under a Track 2 process.

OU 3-07 includes 11 sites at the Tank Farm Area I. Most of the sites in this OU are contaminated with radionuclides and/or mercury. This OU was recommended for further evaluation under OU 3-13 after being investigated under a Track 2.

OU 3-08 consists of six sites associated with the tank farm. The sites include a solvent burner (site CPP-15), contaminated soil in the tank farm (site CPP-27), contaminated soil north and west of the main stack (site CPP-29), a transfer line leak from the old Waste Calcining Facility to WL-102 (site CPP-36), a decontamination solution leak (site CPP-36), and a blowout of contaminated dolomite (site CPF-13). Radionuclides, mercuric nitrate, and nitric acid are the major contaminants suspected (similar to OU 3-07). This OU was recommended for further evaluation under OU 3-13 after being investigated under a Track 2.

OU 3-09 consists of 15 sites, 13 of which are located in the ICPP-603 area. Total volume for the entire $\mathrm{OU}$ is estimated at $257,650 \mathrm{yd}^{3}$. Most of the sites are radiologically contaminated soil areas. This OU was recommended for further evaluation under OU 3-13 after being investigated under a Track 2 .

OU 3-10 consists of four suspected chemical disposal sites: a drainage ditch (site CPP-42), a grease pit (site CPP-44), a pilot plant release (site CPP-46), and an area of nitric acid contamination (site CPP-56). All have been recommended as NFA after being investigated under a Track 2.

OU 3-11 consists of two sites: the Chemical Storage Area (site CPP-45), and the Evaporator Overhead Pipeline (site CPP-58). The Chemical Storage Area has been determined to be NFA. The Evaporator Overhead Pipeline is thought to be a radiologically contaminated soil area caused by spills in the past and will be included for further evaluation under OU 3-13. 
OU 3-12 consists of three sites added to WAG 3. These sites (CPP-80, 81, and 82) consist of soils contaminated with radionuclides and/or hazardous chemicals.

OU 3-13 is the comprehensive RIFS for WAG 3. It also includes perched water zones at the ICPP and other miscellaneous units requiring investigation.

2.3.1.2.4 WAG 4-CFA-CFA is located in the southwest portion of the INEL (see Figure 1-1) about $8 \mathrm{~km}(5 \mathrm{mi})$ south of ICPP. Many services for the entire INEL are located at CFA, including environmental laboratories, security, fire protection, medical, communication systems, warehouses, cafeteria, and vehicle and equipment pools.

WAG 4 has 43 sites that are divided into 13 OUs involving over $3,000,000 \mathrm{~m}^{2}$ ( 800 acres) with approximately $176,000 \mathrm{~m}^{2}$ (44 acres) of potentially contaminated soil. The boundary of WAG 4 is loosely defined because CFA does not have an enclosing fence. However, many CFA sites are located adjacent to buildings (e.g., tanks and dry wells). Others, including landfills and a gravel pit adjacent to one of the landfills, are located on the outskirts of CFA. Other sites include spill areas, USTs, ponds, leach pits, and leach fields. Low levels of radioactive and hazardous material contaminants may be found at the various OUs. The following paragraphs briefly describe each of the OUs.

OU 4-01 includes two sites: the CFA gravel pit (site CFA-09) and a French drain (site CFA-11). Both sites are suspected of containing ordnance (5-in. shells) left over from the Navy Artillery Range operations. This OU was transferred to OU 10-05 and included in an interim action started in 1993.

OU 4-02 consists of five dry wells. There is no record of any of the wells receiving hazardous materials. One well has been deleted from the list of known sites. The others have been listed as NFA following a Track 1 investigation.

OU 4-03 contains 21 empty USTs; all have been removed except the one at site CFA-18. One tank contained sulfuric acid (site CFA-35). The remaining 20 tanks contained petroleum products. The sites have been investigated using a Track 1 process; three (sites CFA-21, 22, and 45) have been recommended for further study under a Track 2 investigation.

OU 4-04 includes three former drum dock sites (CFA-39, 40, and 41) where drums were stored and staged for disposition. There is a concern that some chemicals (oils and solvents) may have leaked to the ground while they were in storage. After a Track 1 investigation, CFA-39 has been signed off as NFA; the other two are under management review.

OU 4-05 consists of a pond that collected liquids drained from building CFA-674 (site CFA-04). There is a concern that the pond may contain some mercury resulting from former calcining operations. This OU also contains a bermed area (site CFA-17) used by the fire department to train personnel. These areas will be sampled for volatiles, semivolatiles, pesticides, polychlorinated biphenyls, and radionuclides. The sites are being evaluated under a Track 2 investigation. 
OU 4-06 consists of three areas that may contain some lead residue. One area (CFA-06) is outside the lead shop where lead shot, bricks, and lead scraps were stored, and where smoke and fumes from lead-pouring operations may have settled on the ground. Site CFA-43 is an area where lead bricks, shot, and scrap were stored while awaiting disposition. This OU also includes CFA-44 Paint Drain. The Track 2 is final and recommends cleanup action be performed at CFA-06; the other two sites have been recommended as NFA.

OU 4-07 consists of the CFA French drains (sites CFA-07 and 12) and associated contaminants. Disposed wastes to the French drains included solvents, oily waste, pesticides, organic chemicals, inorganic chemicals, acids, bases, heavy metals, and low-level radioactive waste. Both sites are being investigated under a Track 2.

OU 4-08 consists of the sewage plant, septic tank, and drain field (site CFA-08). Wastes from sanitary sewage systems, a laundry that handled radioactively contaminated clothing, and other CFA facilities flowed into the system. The Track 2 is being finalized.

OU 4-09 consists of three areas where spills have occurred. One spill area is a transformer yard (site CFA-10) where oil that may have contained polychlorinated biphenyls leaked from the transformers. The other two areas (sites CFA-26 and 42) are locations where fuel oil was spilled or leaked into the ground. The sites are being investigated under a Track 2 .

OU 4-10 is an old municipal-type landfill (Landfill I) (site CFA-01) that received waste from the cafeteria, construction debris, paint thinners, solvents, asbestos, chemicals, and other miscellaneous materials from operations at the INEL from 1951 until 1970. This OU will be incorporated into OU 4-12.

OU 4-11 is the CFA motor pool pond, which received effluent from the vehicle maintenance shop operations during the period 1951 to 1985 . During the 35-yr service life of the motor pool pond, the wastestream mainly consisted of wastewater from washing vehicles. Wastes from vehicle washes can be assumed to have contained metals and organic compounds associated with road dust, oil, and grease. On several occasions, vehicles and equipment with small amounts of radioactive contamination were washed at the station. An NFA Record of Decision for this OU was signed in January, 1993.

OU 4-12 includes two municipal-type landfills, site CFA-02 (Landfill II operated from 1970 to 1982) and site CFA-03 (Landfill III operated from 1982 to 1986), that received materials similar to those at Landfill I (OU 4-10). Groundwater monitoring wells have been drilled at the landfills to monitor water quality beneath the landfills. Initial monitoring indicates the landfills have not impacted the water quality' in the aquifer. The RI/FS and proposed plan have been completed. A public meeting was held in May 1995 to solicit comments which are incorporated here.

OU 4-13 is the comprehensive: RI/FS for WAG 4 and will be used to facilitate remedial work at other waste units requiring cleanup following characterization.

\subsection{WAG 5-Power Burst Facility (PBF) and Auxiliary Reactor Area}

(ARA)-WAG 5 consists of the PBF and ARA. PBF is located in an area originally constructed 
for the Special Power Excursion Reactor Tests (SPERT). Four SPERT reactors were built beginning in the late 1950s in a radial array around what is now the PBF control and personnel building complex. All of the SPERT reactors were removed, and SPERT facilities have undergone partial or complete D\&D. The PBF reactor is still operational, but in a standby mode.

The ARA consists of four separate groupings of buildings in which various activities have occurred, including the operation of test reactors. All of the ARA reactors were removed and the facilities have undergone partial or complete D\&D.

PBF and ARA sites investigated include tanks and components of wastewater disposal systems (such as evaporation and percolation ponds, leach fields, pits, and dry wells). The boundary of WAG 5 encompasses the facility locations presently or historically used within the PBF and ARA areas and those immediately adjacent areas where waste activities may have taken place. The WAG is divided into thirteen OUs and includes all surface and subsurface areas, except those designated as part of WAG 10. The 13 OUs are briefly described in the following paragraphs.

OU 5-01 contains the ARA-I evaporation pond (site ARA-05), ARA-I drain (site ARA-17), three radionuclide tanks (sites ARA-15, 16, and 18), and a fuel oil radionuclides detention tank (site ARA-19). ARA-05 and ARA-17 have been classified as NFA under a Track 1 process. ARA-16 and ARA-19 will have the tanks removed in 1995 and any contaminated soil cleaned up. ARA-15 and ARA-18 had the tanks removed in 1993. The last four are anticipated to be classified as NFA.

OU 5-02 includes the PBF SPERT-I leach pond (site PBF-12), which received radioactively contaminated wastewater from the reactor; the SPERT-III large leach pond (site PBF-21), which received low-level radioactively contaminated water from the reactor; and the SPERT-IV Lake at PBF-758 (site PBF-26), which was used to collect raw cooling water. There is no record of hazardous waste at these sites. PBF-12 has been classified as NFA. PBF-21 has been submitted for approval and site PBF-26 will be further evaluated in the Comprehensive RI/FS for WAG 5 (OU 5-12).

OU 5-03 contains the PBF cooling tower area and drainage ditch (site PBF-28), the PBF reactor pit, which received blowdown water containing small amounts of corrosive inhibitors from the PBF facilities (site PBF-06), the PBF reactor oil drum temporary storage area (concrete pad) (site PBF-07), the PBF rubble pile used during PBF construction (site PBF-13), and the PBF SPERT-IV blowdown pit (site PBF-24), which received radioactively contaminated water. Site PBF-13 has had the asbestos removed and the Track 1 document has been sent to DOE for approval as an NFA. The other sites have been classified as NFA.

OU 5-04 contains the PBF control area fuel oil tank used at one time for the PBF-608 generator (site PBF-04), the SPERT-II fuel oil tank used for the PBF-612 generator (site PBF-14), and the SPERT-III fuel oil tank used for PBF-609 (site PBF-19). The tanks at sites PBF-04 and 19 have been removed. PBF-04 leaked and residual contamination exists under building PBF-608. PBF-19 has been classified as NFA; PBF-14 and PBF-04 are expected to receive the same classification. 
OU 5-05 includes the ARA-II Stationary Low-Power Reactor-1 (SL-1) burial ground, a 4.6-acre area where the demolished SL-1 building was buried. The SL-1 burial ground was created to store and dispose of contaminated material not sent to the RWMC. The site consists of two trenches and one pit. The turial ground is considered to be two separate areas of contamination: the buried waste and the surface contamination. OU 6-01, the Boiling Water Reactor Experiment-1 (BORAX-I) burial site, has been incorporated into this OU and associated investigation. The BORAX-I reactor was intentionally destroyed in 1954; the damaged reactor was buried in place and a layer of soil/gravel placed over the contaminated soil to reduce radiation levels. The RI/FS and Proposed Plan have been completed. A public meeting was held in May 1995 to solicit comments which are incorporated here.

OU 5-06 includes the ARA-III radioactive leach pond (site ARA-12), which received cooling water contaminated with corrosion inhibitors, and the ARA-IV Leach Pit No. 1 (site ARA-20), which received radioactive wastewater. These sites were last used in the late 1950 s and early 1960s. After investigating under a Track 2 investigation, it is recommend that this OU be classified as NFA.

OU 5-07 contains the ARA-I pad near ARA-627 (site ARA-03), where a laboratory trailer possibly containing lead sheeting and hazardous contamination was parked, and the ARA-I Sanitary Septic Tank and Seepage Pit (site ARA-02). This OU has been investigated by a Track 2 investigation and the sites are presently in the cleanup process. This will be included in OU 5-12 RI/FS.

OU 5-08 contains the PBF reactor area warm waste injection well that was used for lowlevel radioactive cooling water disposal (site PBF-05); the PBF SPERT-I seepage pit (site PBF-11), which received regeneration solutions from the SPERT-I demineralizers; and the PBF reactor corrosive waste injection well (site PBF-15), which received regeneration solutions from reactor demineralizers. The Track 2 investigation report has been submitted for management review.

OU 5-09 includes the PBF SPERT-II leach pond (site PBF-16), the PBF SPERT-III small leach pond (site PBF-20), and the PBF SPERT-IV leach pond (site PBF-22), which received regeneration solutions and low-level radioactive wastewater from operations. The Track 2 investigation report has been submitted for management review.

OU 5-10 consists of the ARA-I Chemical/Evaporation Pond (site ARA-01). This pond (known as the ARA I Chemical Waste Pond) was installed in 1970 as an unlined surface impoundment of ARA 627. This building was a print shop, materials research facility, and radiochemistry laboratory. The pond received waste discharges from this building from 1970 to 1988. A remedial investigation was conducted to determine risks associated with ARA-01. In a Record of Decision dated December 1992, DOE, with EPA and Idaho Department of Health and Welfare concurrence, determined that no further remedial action is necessary for this site.

OU 5-11 comprises the ARA-III sanitary sewer leach field and septic tank (site ARA-13). This OU has been determined to be NFA based on a Track 1 investigation. 
OU 5-12 is the comprehensive RI/FS. Information and decisions from WAG 5 Track 1 and 2 activities as well as intermediate Records of Decision will be integrated. Any interim actions will support the comprehensive RI/FS.

OU 5-13 includes the PBF sump brine tank (site PBF-08) and the PBF evaporation pond (site PBF-10). PBF-08 is an unlined concrete structure used during the neutralization of spent reactor secondary coolant water, prior to discharge to the evaporation pond. The evaporation pond is a lined surface impoundment. A Record of Decision was issued for both sites requiring remediation because of the immediate human health risk posed by chromium contamination. The corrosive waste sump remedial action was completed in December 1994 and was covered by a separate Auditable Safety Analysis (ASA).

\subsection{WAG 6-Experimental Breeder Reactor No. I (EBR-I) and}

BORAX-WAG 6 consists of the EBR-I and BORAX areas. Both areas were originally constructed to house test reactors and have since been decommissioned. EBR-I currently is designated as a National Historical Landmark. The BORAX area was the site of five different reactors, but many of the facilities were removed and no operations are occurring. BORAX-I was intentionally destroyed in 1954 and a new site, northeast of BORAX-I was selected for BORAX-II through BORAX-V. The BORAX-V facility is currently undergoing D\&D. Twenty-one sites have been identified at WAG-6 and are divided into 5 OUs, including old tanks, a small spill, and several liquid and solid waste disposal sites. Possible contaminants include heavy metals, petroleum products, and radionuclides.

OU 6-01 consists of the buried remains of the BORAX-I reactor (site BORAX-02). This site has been transferred to WAG 5 OU 5-05/6-01 RI/FS (see Section 2.3.1.2.5).

OU 6-02 includes five miscellaneous sites consisting of a leach pond previously used for wastewater disposal (site BORAX-01), a septic tank used for sanitary wastewater disposal (site BORAX-03), a trash dump used for nonradioactive reactor and office waste disposal (site BORAX-04), a wastewater ditch (site BORAX-08), and a buried reactor building (site BORAX-09). The BORAX-04 and BORAX-05 have been signed off as NFA. The leach pond, wastewater ditch, and buried reactor building are being evaluated further under OU 10-06 RI/FS.

OU 6-03 contains a collection of 10 out-of-service petroleum USTs. Six (sites EBR-07, 09, $11,12,13$, and 14) have been signed as NFA. The remaining four (sites BORAX-05, BORAX-07, EBR-08, and EBR-10) have been submitted for signature.

OU 6-04 consists of radioactive soil contamination from a spill involving activities at EBR-I (site EBR-15). EBR-15 consists of two areas in the vicinity of EBR-I contaminated with ${ }^{137} \mathrm{Cs}$. When first detected in 1988, Area 1 was approximately $9,900 \mathrm{ft}^{2}$ and Area 2 was approximately $6,800 \mathrm{ft}^{2}$. This OU will be included in the OU 10-05 RI/FS.

OU 6-05 is the comprehensive RI/FS for WAG 6 and will be incorporated into the overall site-wide RI/FS to be performed under 10-04 beginning in 1998.

2.3.1.2.7 WAG 7-RWMC-The RWMC was established in 1952 as a controlled area for the disposal of solid radioactive wastes. The primary RWMC site being investigated under the 
FFA/CO is the SDA. Located on the west side of the RWMC, the SDA includes numerous pits, trenches, and vaults where radioactive and organic wastes were placed, and a large aboveground pad where waste containers were stacked and covered. To the east of the SDA is the Transuranic Storage Area (TSA), an aboveground facility for storage of transuranic (TRU) waste and associated support facilities. The TSA complex includes the Stored Waste Examination Pilot Plant Project, which is not part of the WAG 7 activities. WAG-7 is divided into 14 OUs.

OU 7-01 are all SDA soil vaults containing waste introduced between 1977 and 1983, rows 1 through 13. Soil vaults are cylindrical holes drilled into the ground for disposal of waste with radiation levels in excess of $500 \mathrm{mF} / \mathrm{hr}$ at $3 \mathrm{ft}$ from the container surface. If a vault's floor was basalt rock, soil was placed over the basalt. Each vault is separated from any previously buried waste by a minimum of $2 \mathrm{ft}$. When filled, each vault is covered with a soil layer. Suspected contaminants include radioactive and nonradioactive hazardous materials.

OU 7-02 consists of the SDA acid pit located near the center of the SDA (site RWMC-04). The pit was in use from 1954 to 1951. It extends down to the top of the first basalt layer. Geophysical surveys indicate metal objects in the pit. Suspected contaminants include radioactive and nonradioactive hazardous materials. The Track 2 scoping investigation was completed in 1994.

Reports indicate that as acids were placed in the pit, lime was periodically added to neutralize the acids. A soil cover was added on a daily or weekly basis. The pit received both liquid organic and inorganic wastes, some containing radionuclides. Informational searches indicate that disposed wastes include carbon tetrachloride, organic solvents (trichloroethylene, trichloroethane, and tetrachloroethylene), radioactively contaminated acids, and cleaning solutions. Radioactive contaminants are believed to be low-level wastes, primarily $\mathrm{U}$, with some ${ }^{90} \mathrm{Sr},{ }^{137} \mathrm{Cs}$, ${ }^{60} \mathrm{Co}$, and TRU radionuclides. The acids include nitric, sulfuric, hydrofluoric, and aluminum acids. Quantities added varied considerably, with the largest additions in the range of $40,000 \mathrm{gal}$.

OU 7-03 consists of the non-TRU contaminated waste pits and trenches (site RWMC-04). Suspected contaminants include raclioactive and nonradioactive hazardous materials. Wastes were generated in a large number of on- and offsite facilities and disposed in these trenches. Material in the trenches is in excess of $75,000 \mathrm{~m}^{3}$. Data indicate that some migration of radionuclides and volatile organics to surface soils occurred. Burials took place in the 1960 s and early 1970 s.

OU 7-04 consists of the air pathways for the RWMC. Suspected contaminants include radioactive and nonradioactive hazardous materials. Air monitoring for particulate radionuclides currently is conducted as part of a regular monitoring program at the RWMC. No regular monitoring is conducted for nonraclioactive materials. Potential sources for air contaminants include the active pits, TRU waste, TRU mixed waste, low-level mixed waste, hazardous waste buried in the pits and trenches, and liquid wastes poured into selected pits at the RWMC. Soil gas surveys taken during a screening for 13 compounds identified 1,1,1-trichloroethane, carbon tetrachloride, trichloroethylene, tetrachloroethylene, and chloroform. The Track 2 investigation has been completed.

OU 7-05 consists of the surface water pathways and surficial sediments associated with the RWMC. Suspected contaminants include radioactive and nonradioactive hazardous materials. 
The surface water pathway and surficial sediments were defined as surficial sediments to a depth of $1 \mathrm{ft}$ within the local drainage basin of the RWMC that may have been contaminated with surface water runoff from the RWMC. Track 2 risk assessments indicate that current levels of contamination do not pose a risk above the currently acceptable risk levels (that is, less than 1E-04), using conservative risk calculations. Further analysis will be performed in the RI/FS.

OU 7-06 consists of the groundwater pathway associated with the RWMC. Suspected contaminants include radioactive and nonradioactive hazardous materials. These contaminants are associated with the subsurface soils and groundwater. Further identification of the extent of contamination will be part of the Track 2 scoping investigations and RI/FS work.

OU 7-07 consists of the vadose zone associated with the RWMC. The vadose zone is described as the subsurface region, beginning at the surface, down to the top of the Snake River Plain Aquifer. For this OU, the contaminants under study in the vadose zone are limited to radionuclides and metals. Organic contamination in this zone is addressed in OU 7-08. Radionuclides found in vadose zone samples in the past include ${ }^{3} \mathrm{H},{ }^{60} \mathrm{Co},{ }^{137} \mathrm{Cs},{ }^{154} \mathrm{Eu},{ }^{238} \mathrm{Pu}$, ${ }^{239} \mathrm{Pu},{ }^{240} \mathrm{Pu}$, and ${ }^{241} \mathrm{Am}$. Inorganic compounds were detected in the vadose zone. A reference for the radionuclides and organics is RI/FS Work Plan of the Subsurface Disposal Area, Radioactive Waste Management Complex at the INEL, EGG-WM-8776 (EG\&G 1989). The specific types and concentrations of contaminants will be determined as part of the Track 2 investigations.

OU 7-08 consists of the RI/FS for the vadose zone associated with the RWMC. For this $\mathrm{OU}$, investigation and potential remediation of contaminants are limited to volatile organic compounds (VOCs). Radionuclides and metal contamination are addressed in OU 7-07. Primary sources of VOC contamination and release mechanisms were identified as inactive pits and trenches. Contaminants could be released from these areas to the air through volatilization or through leaching to the groundwater by infiltration of surface water.

Vapor vacuum extraction was investigated as a potential remediation technology for VOC contamination. The system was tested for periods of $2 \mathrm{wk}$ and 4 mo. During these tests, $1,116 \mathrm{lb}$ of carbon tetrachloride and $427 \mathrm{lb}$ of trichloroethylene were removed. The test system used vapor phase granular-activated carbon to capture organic vapors. A full scale system will probably use a catalytic oxidation offgas treatment system that will destroy the organic contaminants.

OU 7-09 consists of the contaminant releases from the TSA (site RWMC-05). The TSA is a 56-acre area consisting of four aboveground storage pads and soil vaults. The TSA and waste stored in the TSA are regulated by RCRA and are not part of WAG 7. The TSA was established in 1970 for retrievable storage of waste with contamination levels of TRU greater than $10 \mathrm{nCi} / \mathrm{g}$. Waste is stored aboveground on asphalt pads. After a section of a pad was filled with waste containers, successive layers of plywood, nylon-reinforced polyvinyl sheeting, and approximately $3 \mathrm{ft}$ of soil were placed over the containers. The wastes were generated by operations conducted in support of DOE (and formerly Atomic Energy Commission) programs at numerous locations.

The total volume of waste placed at TSA between 1970 and 1980 was approximately $1,500,000 \mathrm{ft}^{3}$. This OU encompasses any past releases from the wastes at TSA. Previous sampling programs have not identified any contamination in excess of regulatory limits near TSA 
pads. A Track 1 investigation has been completed. A final decision for this OU will be made during the RI/FS.

OU 7-10 consists of the Pit 9 demonstration project (site RWMC-04). Pit 9 is located in the northeast corner of the SDA, and cannot be easily distinguished from the surface since soil was placed over the pit. The inventory of wastes buried in the pit was estimated from available shipping records and the Radioactive Waste Management Information System. Wastes include drums of sludge, drums of assorted solid waste, cardboard boxes containing empty drums, an inactive reactor vessel, and other large, contaminated metal objects. This site is scheduled for interim action.

The dimensions of Pit 9 are approximately $127 \times 379 \mathrm{ft}$, with a depth from ground surface to bedrock of approximately $17.5 \mathrm{ft}$. The pit contains approximately $150,000 \mathrm{ft}^{3}$ of buried waste, primarily TRU (according to the 1969 definition), and hazardous wastes. Approximately $75 \%$ of the waste was generated at the Rocky Flats Plant, with additional waste from generators at the INEL. Pit 9 contains about 4,000 drums of sludges and solid waste and about 2,500 cardboard boxes of solid wastes. About 80 unspecified containers of waste are buried in the pit. The boxes were disposed, in general, at the north end of the pit, and the drums were dumped at the south end. Some intermixing of containers in the pit did occur.

OU 7-11 encompasses three sites designated as NFA sites. One is the RWMC drainage and septic tank for WMF-613 (site RWMMC-01). The tank has a volume of 1,250 gal, is assumed to be made of concrete, and includes a drain field constructed of 4 -in. perforated plastic drain tile. The system was put into operation in 1986. Site RWMC-02 is a 2,000 gal concrete septic tank servicing WMF-601, WMF-604, and WMF-620, with a drain field constructed of 4-in. perforated plastic drain tile. The system was put into operation in 1976 when WMF-601 was built. The drain field for RWMC-02 failed and was replaced in 1986. The new drain field was installed in the same location. Site RWMC-03 is a 2,000 gal tank with an associated drain field constructed of 4-in. perforated polyvinyl chloride pipe. These sites received a decision of determination of NFA dated January 7, 1993.

OU 7-12 consists of the RI/FS for Pad A (site RWMC-04). Pad A is a 2- to 3-in.-thick asphalt surface laid over a gravel base and measuring $240 \times 335 \mathrm{ft}$. The pad was built in 1972 for the aboveground disposal of mixed wastes that did not meet the TRU definition (waste with $>10 \mathrm{nCi} / \mathrm{gm}$ TRU). Wastes stored on Pad A are contaminated with relatively small amounts of depleted uranium, plutonium, and other TRU nuclides, along with other materials, such as sodium and potassium salts (mostly nitrates), and sewer sludges. Wastes were disposed in about 2,000 plywood boxes $(4 \times 4 \times 7 \mathrm{ft})$ and about 18,000 55-gal drums. Drums were stacked horizontally in staggered layers up to 11 high. Boxes were stacked a maximum of five high. When the pad was closed for operation in 1979, waste containers occupied about half the pad (about 32,000 $\mathrm{ft}^{2}$ ). Closure involved placing plywood, polyethylene, or both over the containers and covering with a minimum of $3 \mathrm{ft}$ of soil. The soil overburden was seeded with crested wheat grass.

Extent of contamination is under investigation as part of the RI/FS process. No measurable levels of contaminants from Pad A were detected in the soil adjacent to the pad, groundwater, surface water, or offsite. 
OU 7-13 consists of the RI/FS for the TRU pits and trenches (site RWMC-04). Wastes disposed in these pits and trenches included TRU, low-level, and mixed wastes in solid and liquid form. Disposal of TRU-contaminated wastes at SDA ceased in 1970. There are 14 pits and 27 trenches containing TRU contamination. Soils around or beneath these pits and trenches contaminated by TRU or hazardous materials are part of this investigation.

OU 7-14 consists of the WAG 7 Comprehensive RI/FS and has combined with OU 7-13.

2.3.1.2.8 WAG 10-Miscellaneous-WAG 10 includes the regional Snake River Plain Aquifer, other areas and sites related to the INEL that cannot be addressed on a WAG-specific basis, and surface disposal sites and ponds identified at the INEL that are not included in other WAGs. The WAG has been divided into 7 OUs. These OUs include pits, a pond, ordnance areas, miscellaneous surface sites, and liquid disposal areas. Possible contaminants include waste oils, solvents, ordnance, and radionuclides.

OU 10-01 contains two disposal pits at the Liquid Corrosive Chemical Disposal Area (LCCDA) located approximately $0.6 \mathrm{~m}$ east of the main RWMC gate (sites LCCDA-01 and 02). The pits were used between the late 1950s and 1981, primarily for the disposal of corrosive chemicals. A Track 2 investigation was performed and this OU will likely be included in the OU 10-04 RI/FS (Hull 1994).

OU 10-02 consists of the Organic Moderated Reactor Experiment (OMRE) Leach Pond located between WAGs 4 and 5 (behind the Security Training Facility) (site OMRE-01). It was used for wastewater disposal from the OMRE and has suspected solvent and radionuclide contamination. A Track 2 investigation is planned with an anticipated classification of NFA.

OU 10-03 consists of ordnance areas, including the Naval Ordnance Disposal Area, which is not contained in other WAGs. These areas include a bombing range and areas used to test large-caliber guns. A Track 2 investigation is in progress. Removal actions are covered by an unreviewed safety question screen to the OU 10-05 Safety Analysis Report (SAR).

OU 10-04 is designated as the Comprehensive/Snake River Aquifer RI/FS and includes all miscellaneous surface sites and liquid disposal areas throughout the INEL not included in other WAGs. The regional Snake River Plain Aquifer, defined by the INEL boundary, will be studied, and extent of the contamination will be determined accordingly. It is scheduled to start in 1998.

OU 10-05 consists of areas where unexploded ordnance may be found at other WAGs excluding those listed in 10-03. Four interim action alternatives were presented in the Record of Decision for this OU. An Auditable Safety Analysis for Interim Action to Clean Up Unexploded Ordnance Locations at the Idaho National Engineering Laboratory, (MK-FIC 1993c) was prepared for this remediation activity.

OU 10-06 includes areas of windblown radioactive contamination and other INEL OUs identified as containing primarily radionuclide-contaminated soils. The windblown areas are those areas outside administratively controlled areas [i.e., TAN, ICPP, TRA, PBF, RWMC, ARA, EBR-I, BORAX, and Argonne National Laboratory-West (ANL-W)] and within the outermost 
EG\&G Energy Measurements, Inc., aerial survey isopleths (conducted from June 6 to August 3, 1990). This is being worked under an RI/FS investigation.

OU 10-07 is the buried U.S. West telecommunications cable installed by U.S. West Communications in the early $1950 \mathrm{~s}$. The cable consists of copper wiring with paper insulation, enclosed by a lead sheathing approximately $1 / 8$ in. thick. It is wrapped in spiraled shell and enclosed in jute wrapping impregnated with an asphalt-like substance. The cable has a diameter of approximately 2 in., measures $36.5 \mathrm{mi}$ in length, and is buried 3 to $4 \mathrm{ft}$ below land surface. The cable originates at CFA and extends parallel to and approximately 100 yd east of Lincoln Boulevard to ICPP, TRA, Naval Reactor Facility (NRF), and TAN. The cable was cut and rendered useless in the spring of 1990 when a new cable was installed. This has been classified as NFA using a Track 1 investigation.

\subsubsection{D\&D}

D\&D activities address the management of surplus radioactively contaminated facilities to permit other uses of those facilities or the occupied land. D\&D activities will be performed to ensure that releases and exposure to radioactively contaminated and other hazardous materials are in compliance with Federal and state standards. D\&D projects will meet the requirements of DOE Order 5820.2A, Chapter V, "Decommissioning of Radioactively Contaminated Facilities."

D\&D activities at the INEL are driven by DOE-ID schedules for cleaning up contaminated surplus facilities. A facility is declared "surplus" if the programmatic sponsor so designates and no future programs are identified for the facility. Facilities may be added or removed from scheduled $\mathrm{D} \& \mathrm{D}$ activities in response to programmatic INEL mission and funding changes.

Through fiscal year 1994, 27 facilities went through D\&D (EG\&G 1993d). Some facilities were dismantled and all evidence of existence removed; others had contamination removed and useful parts of the facilities reused.

D\&D activities may generate all types of waste, including industrial municipal, hazardous, radioactive, and mixed wastes, depending on the type of facility. Anticipated wastes generated from facilities currently scheduled for D\&D are summarized in Table 2-1. The volumes of waste are expected to greatly impact the recessity for various treatment, storage, and disposal facilities for waste handling. Exact volumes of waste are difficult to predict because overall remedial goals affect types and volumes of secondary wastestreams produced. Technology development would be required for some activities.

D\&D planning for each excess facility includes assignment of a priority; radiological, chemical, and physical characterization; decision analysis to select preferred D\&D alternative; and preparation of a D\&D plan. Facilities awaiting D\&D are maintained to limit exposure of workers, the public, and the enviroriment to potential hazards.

Planned or proposed D\&D projects are identified in Table 2-1. For more detailed descriptions and layouts, see the INEL D\&D Long Range Plan (EG\&G 1995). D\&D projects for the NRF and ANL-W are not within the scope of this BSAF. Detailed facility layouts are required in the Health and Safety Plan and are discussed in Chapters 9 and 10. Estimated 
Table 2-1. Facilities scheduled for D\&D and the types of waste expected to be generated.

\begin{tabular}{|c|c|c|}
\hline Location & Facility & Types of waste \\
\hline \multirow[t]{2}{*}{ TAN } & $\begin{array}{l}\text { Loss-of-Fluid Test Facility (LOFT) } \\
\text { Ancillaries Mobile Test Assembly } \\
\text { (MTA) }\end{array}$ & $\begin{array}{l}\text { Low Level; Mixed; Industrial } \\
\text { Municipal }\end{array}$ \\
\hline & Technical Support Facility (TSF) & Low Level; Industrial Municipal \\
\hline \multirow[t]{3}{*}{ TRA } & Engineering Test Reactor (ETR) & $\begin{array}{l}\text { Low Level; Mixed; Industrial } \\
\text { Municipal }\end{array}$ \\
\hline & Materials Test Reactor (MTR) & $\begin{array}{l}\text { Low Level; Mixed; Industrial } \\
\text { Municipal }\end{array}$ \\
\hline & Test Train Assembly Facility & Low Level; Industrial Municipal \\
\hline $\begin{array}{l}\text { Army Re-entry Vehicle Facility Site } \\
\text { (ARVFS) }\end{array}$ & ARVFS & $\begin{array}{l}\text { Hazardous; Low Level; Mixed; } \\
\text { Industrial Municipal }\end{array}$ \\
\hline \multirow[t]{7}{*}{ ICPP } & $\begin{array}{l}\text { Service Waste Diversion Facility } \\
\text { (CPP-631, 660, 709, 734)) }\end{array}$ & Low Level; Industrial Municipal \\
\hline & $\begin{array}{l}\text { Fuel Receipt and Storage Facility } \\
\text { (CPP-603) }\end{array}$ & Low Level; Industrial Municipal \\
\hline & $\begin{array}{l}\text { Fuel Processing Building } \\
(\mathrm{CPP}-601,631)^{\mathrm{a}}\end{array}$ & $\begin{array}{l}\text { Low Level; Mixed; Industrial } \\
\text { Municipal }\end{array}$ \\
\hline & Headend Processing Plant (CPP-640) ${ }^{\mathrm{a}}$ & Low Level; Industrial Municipal \\
\hline & $\begin{array}{l}\text { High Level Waste Tank Farm } \\
\text { (Storage tanks (11) and vaults) }\end{array}$ & $\begin{array}{l}\text { High Level; Low Level; Mixed; } \\
\text { Industrial Municipal }\end{array}$ \\
\hline & $\begin{array}{l}\text { Stored Fuel Exterior (SFE) (SFE-20, } \\
\text { CPP-642, 740) }\end{array}$ & Low Level; Industrial Municipal \\
\hline & Waste Calcine Facility (CPP-633) ${ }^{2}$ & $\begin{array}{l}\text { Low Level; Mixed; Industrial } \\
\text { Municipal }\end{array}$ \\
\hline PBF/ARA & ARA I, II, III & $\begin{array}{l}\text { Low Level; Mixed; Industrial } \\
\text { Municipal }\end{array}$ \\
\hline BORAX & BORAX-V & $\begin{array}{l}\text { Low Level; Mixed; Industrial } \\
\text { Municipal }\end{array}$ \\
\hline
\end{tabular}


inventories of radioactive and hazardous materials are contained in the INEL D\&D Long Range Plan (EG\&G 1995). Estimated quantities of radioactive and hazardous waste generated from D\&D activities are contained in INEL Technical Site Information (EG\&G 1993c). The status of each of the D\&D sites is presented in Table 2-2.

\subsection{Facility Structure}

This section provides an overview of the basic facility buildings and structures, including construction details such as basic floor plans, equipment layout, construction materials, controlling dimensions, and dimensions significant to the hazards and accident analysis activity. This section is not applicable to environmental remediation activities not associated with facilities, which includes most environmental remediation activities. The description of the facility for D\&D activities should be sufficient to give an overall understanding of the facility structure and the general arrangement of the facility as it pertains to the hazard and accident analyses.

\subsection{Process Description}

\subsubsection{Remedial Action Techniques}

Contaminated sites at the INEL contain a variety of waste types. Different types of remedial action techniques will be employed to clean the sites to acceptable levels as part of the CERCLA-based FFA/CO process. For each particular site, one or more of the treatment options may need to be employed, depending on the type of contamination present.

The following subsections describe the remedial action methods and techniques currently used, or planned, for environmental remediation of INEL sites. The technologies described here are limited to the types of remediation technologies listed in the Environmental Restoration Program Major System Acquisition Baseline (EG\&G 1993b). In addition, remedial action methods and technologies not currently being used, or planned, for environmental remediation of INEL sites are also addressed and identified. The technologies described include methods proven effective, as well as some promising, unproven methods. Table 2-3 presents a summary of methods currently in use or planned at the INEL for environmental remediation activities. This table is from the Environmental Restoration Program Major System Acquisition Baseline, DOE/ID-0000, April 1993 (EG\&G 1993b).

2.5.1.1 Containment. Containment technologies are designed to reduce mobility of contaminants by creating a barrier to prevent waste outflow from the site or creating a subsurface or surface diversion to prevent water from flowing through or over a site.

2.5.1.1.1 Capping-For closure in place of a trench or pit landfill, a low-permeability cap of native soil, asphalt, or concrete is used to cover the landfill to minimize migration of liquids into waste materials. RCRA recommends a multi-layered cap composed of three layers: a top layer of native soil and vegetation, a drainage layer of sand or other granular material, and a lowpermeability layer of compacted soil. 
Table 2-2. Status of D\&D Facilities.

\begin{tabular}{|c|c|c|c|}
\hline Facility & $\begin{array}{l}\text { Hazard } \\
\text { classification }\end{array}$ & Status & SAR \\
\hline LOFT Ancillaries MTA & $\mathbf{N A}$ & S\&M & TAN Hot Cell Complex Final SAR (INEL 1991c) \\
\hline TSF & $<$ Category 3 & S\&M & SAR for the TAN-607 Complex (EG\&G 1986) \\
\hline ETR & Category 3 & $S \& M$ & $\begin{array}{l}\text { SAR for inactive status completed in } 1986 \text { with no updates } \\
\text { since. }\end{array}$ \\
\hline MTR & Category 3 & S\&M & Current SAR covers laboratory type operations in MTR. \\
\hline $\begin{array}{l}\text { Test Train Assembly } \\
\text { Facility }\end{array}$ & Category 2 & In use & $\begin{array}{l}\text { Existing SAR out of date for inactive facility status. Draft } \\
\text { updated but not to } 5480.23 \text { format. }\end{array}$ \\
\hline ARVFS & $<$ Category 3 & $\begin{array}{l}\text { Used for } \\
\text { Storage }\end{array}$ & $\begin{array}{l}\text { ASA for storage and handling of the EBR-I NaK (Klassy } \\
\text { 1994) }\end{array}$ \\
\hline $\begin{array}{l}\text { Service Waste Diversion } \\
\text { Facility }\end{array}$ & OIF & $\mathrm{D} \& \mathrm{D}$ & $\begin{array}{l}\text { Hazard classification documented in INEL-95/100. D\&D } \\
\text { to start } 10 / 95 .\end{array}$ \\
\hline $\begin{array}{l}\text { Fuel Receipt and Storage } \\
\text { Facility }\end{array}$ & NA & In use & Updating SAR to 5480.23 format \\
\hline Fuel Processing Building & NA & In use & Updating SAR to 5480.23 format \\
\hline Headend Processing Plant & NA & In use & Updating SAR to 5480.23 format \\
\hline $\begin{array}{l}\text { High Level Waste Tank } \\
\text { Farm }\end{array}$ & NA & In use & Updating SAR to 5480.23 format \\
\hline SFE & NA & S\&M & D\&D SAR not written yet. \\
\hline Waste Calcine Facility & NA & In use & Updating SAR to 5480.23 format \\
\hline ARA I & Radiological & $D \& D$ & $\begin{array}{l}\text { SAR for the Auxiliary Reactor Area I (INEL 1992c), SAR } \\
\text { for D\&D of ARA-626 is scheduled for completion in July } \\
1995\end{array}$ \\
\hline ARA II & Low & $\mathrm{D} \& \mathrm{D}$ & $\begin{array}{l}\text { SAR for the Auxiliary Reactor Area (ARA-II) at the } \\
\text { INEL (INEL 1992d) }\end{array}$ \\
\hline ARA III & OIF & $\mathrm{D} \& \mathrm{D}$ & $\begin{array}{l}\text { SAR for the Auxiliary Reactor Area (ARA-III) at the } \\
\text { INEL (INEL 1992e) }\end{array}$ \\
\hline BORAX-V & $<$ Category 3 & $D \& D$ & $\begin{array}{l}\text { SAR for the D\&D of the BORAX-V Facility (INEL } \\
\text { 1992f) }\end{array}$ \\
\hline \multicolumn{4}{|c|}{$\begin{array}{l}\text { OIF = Other industrial facility } \\
\text { S\&M = Surveillance and maintenance } \\
\text { NA = not available. }\end{array}$} \\
\hline
\end{tabular}


Table 2-3. Anticipated remediation matrix.

\begin{tabular}{|c|c|c|}
\hline Contamination & Remediation & Disposal \\
\hline $\begin{array}{l}\text { Mixed-Waste-Contaminated Soil } \\
\text { and Sediments }\end{array}$ & $\begin{array}{l}\text { Physical/Chemical Extraction } \\
\text { Process }\end{array}$ & $\begin{array}{l}\text { RWMC and RCRA Subtitle D } \\
\text { Facility }\end{array}$ \\
\hline $\begin{array}{l}\text { TCE Radioactive Contaminants } \\
\text { in Groundwater }\end{array}$ & $\begin{array}{l}\text { Air Stripping/Carbon } \\
\text { Absorption, Ion Exchange }\end{array}$ & Offsite Disposal and RWMC \\
\hline $\begin{array}{l}\text { Hazardous-Waste-Contaminated } \\
\text { Soil }\end{array}$ & $\begin{array}{l}\text { Physical/Chemical Extraction } \\
\text { P:ocess }\end{array}$ & $\begin{array}{ll}\text { a. } & \text { Offsite Disposal } \\
\text { b. } & \text { RWMC and RCRA } \\
& \text { Subtitle D Facility }\end{array}$ \\
\hline $\begin{array}{l}\text { Contaminated Soils and } \\
\text { Debris-Heavy Metal }\end{array}$ & $\begin{array}{l}\text { a. Physical/Chemical Extrac- } \\
\text { tion Process } \\
\text { b. Multi-Layered Capping }\end{array}$ & $\begin{array}{l}\text { a. RCRA Subtitle D Facility } \\
\text { b. Onsite In Place }\end{array}$ \\
\hline $\begin{array}{l}\text { Radiologically Contaminated } \\
\text { Concrete/Soils }\end{array}$ & $\begin{array}{l}\text { a. Hot Box (waste container } \\
\text { for radioactive material) } \\
\text { b. Multi-Layered Capping } \\
\text { c. Physical/Chemical } \\
\text { d. Extraction Process } \\
\text { d. Stabilization }\end{array}$ & $\begin{array}{ll}\text { a. } & \text { RWMC } \\
\text { b. } & \text { In Place } \\
\text { c. } & \text { RCRA Subtitle D Facility } \\
\text { d. } & \text { Onsite }\end{array}$ \\
\hline Pb-Contaminated Soil, Pb Scrap & $\begin{array}{l}\text { Encapsulation } \\
\text { (Proposed Best Demonstrated } \\
\text { Available Technology) }\end{array}$ & Offsite \\
\hline $\begin{array}{l}\text { Solvent/Paint-Contaminated } \\
\text { Soils }\end{array}$ & RCRA incineration & Offsite \\
\hline PCB-Contaminated Soil & $\begin{array}{l}\text { Toxic Substances Control Act } \\
\text { Incineration }\end{array}$ & Offsite \\
\hline Municipal Landfill Wastes & Mlulti-Layered Capping & In Place \\
\hline Petro-Contaminated Soils & Bioremediation & Onsite \\
\hline $\begin{array}{l}\text { Nitroaromatic-Contaminated } \\
\text { Soils }\end{array}$ & RCRA Incineration & Offsite \\
\hline VOCs in Vadose Zone & Vapor Vacuum Extraction & Onsite \\
\hline
\end{tabular}


A cap must be constructed to meet specified design and performance standards, and requires $30 \mathrm{yr}$ of post-closure maintenance, which can be considered a major drawback. Since a landfill is considered a permanent structure, the future use of the site is limited.

2.5.1.1.2 Surface Impoundment-This is a potential remedial action technology that is not currently being used, or planned, for environmental remediation of INEL sites. A surface impoundment is a man-made depression or excavation designed to contain an accumulation of liquid wastes or sludges. A surface impoundment is installed with a double liner system to minimize potential for soil and groundwater contamination.

Though a surface impoundment can be "clean closed" by removing and treating all waste and containment system components, the same requirements defined for landfills require compliance.

2.5.1.1.3 Vertical barrier-Slurry Walls-This is a potential remedial action technology that is not currently being used, or planned, for environmental remediation of INEL sites. A vertical barrier can be placed underground in the path of a contaminated groundwater plume. Slurry walls can be constructed from cement grout or bentonite to retard groundwater flow. Alternately, a wall of limestone acts as a neutralizing agent to effectively adjust the $\mathrm{pH}$ of an acidic plume. Cost to construct a wall is relatively high. If heavy metals are present in water, the precipitation clogs the slurry wall. Furthermore, with very little mixing in an aquifer, only the leading edge of the plume comes in contact with the wall.

2.5.1.1.4 Subsurface horizontal barrier-grout injection-This is a potential remedial action technology that is not currently being used, or planned, for environmental remediation of INEL sites. Cementatious grout is forced under pressure below and/or above the contaminated region of soil to prevent migration of contaminants in a vertical direction.

2.5.1.1.5 Subsurface horizontal barrier-Cryogenic barrier-This is a potential remedial action technology that is not currently being used, or planned, for environmental remediation of INEL sites. A liquid nitrogen solution is chilled, then pumped to a location under the soil surface where it freezes in place. This frozen boundary acts as a barrier to any movement by the contaminants.

2.5.1.2 Immobilization. Immobilization technologies are treatments applied to wastes to prevent migration of contaminants to the surrounding environment. In general, these technologies consist of agents mixed with waste materials to prevent migration, without destroying the hazardous constituents. By comparison, high heat vitrification thermal treatment technologies will destroy organic material while immobilizing inorganics and radionuclides.

2.5.1.2.1 Solidification/stabilization-Stabilization is the process of converting liquid wastes into a form that contains as little freestanding and noncorrosive liquid as is reasonably achievable. This process stabilizes the waste, essentially immobilizing the contaminants and improving the stability of any radioactive component. Stabilization process materials include Portland cement and pozzolanic materials such as fly ash. For large areas, such as surface impoundments, materials are introduced directly into liquid waste, creating a solidified mass. The mass is covered with a multi-layered cap to provide long-term minimization of precipitation and run-off into the closed impoundment. Small amounts of hazardous or radioactive liquid waste are 
immobilized by waste transfer to a clisposable container, addition of stabilizers, and solidification of the mass. The container is disposed as a solid waste.

Though the stabilization process is an effective means of immobilizing contaminants in liquid wastes, side products generated by the process may increase the final volume of waste materials. During in situ solidification/stabilization, problems may occur if the final cover settles differentially over the unit, creating channels through which liquids can enter the unit.

2.5.1.2.2 Surface encapsulation-This is a potential remedial action technology that is not currently being used, or planned, for environmental remediation of INEL sites. For friable materials such as asbestos, encapsulation prevents fibers or dust from becoming airborne by effectively sealing the material in situ. The most common encapsulates are thermoplastics and organic polymers, which are applied to the material with a sprayer.

Encapsulation is an inexpensive and effective short-term solution to treating friable materials and does not generate additional waste. However, since it is only a temporary solution, long-term risks must be considered.

2.5.1.3 Physical Treatment. Physical treatment processes separate hazardous constituents from contaminated material, usually followed by treatment for the removed hazardous components. Physical treatment methods involve the use of newly constructed, temporary, or portable process equipment and related structures. The INEL currently has a portable water treatment unit in use, or available for use, accompanied by completed safety analyses, Waste Reduction Operations Complex Portıble Water Treatment Unit Auditable Safety Analysis (INEL 1993a) and Waste Reduction Operations Complex Portable Water Treatment Unit Operational/Technical Safety Requirements (INEL 1993b).

2.5.1.3.1 Physical separation process-The following processes are used for physical separation:

- Screening: Involves use of a mesh of determined size openings to allow material to pass through below a certain size while retaining larger particles.

- Clarification: Permits settling of suspended solids out of water. Involves use of a clarifier tank and support equipment to circulate water and remove settled solids.

- Flotation: Allows removal of floating material from water. Can be done in a tank, such as an oil-water separator, or in an extraction well by skimming floating material off the groundwater layer.

2.5.1.3.2 Air stripping-Air stripping is effective in the treatment of water with low levels of VOCs. This method relies on exposure of contaminated water to a fresh air supply. As air is introduced into the water, VOCs in the water are driven out of the solution and into the vapor state. The most common type of air stripping is packed tower aeration, in which air and water are run counter-current through a randomly structured medium, which exposes a large amount of liquid surface area to the air. The air carries the contaminants out of the stripper and into the atmosphere where VOCs are either dissipated by wind currents or broken down by 
natural ultraviolet degradation. The treated water passes out of the column for use, discharge, or further treatment. Packed towers are typically composed of a cylindrical tower shell, tower internals (including a mist eliminator and a water distributor), packing, air delivery systems (including a forced draft blower at the base of the tower or vacuum blower off the top of the tower), and water delivery systems (including extraction wells, pumps, and holding tanks). Drawbacks to the air stripping process are restricted mainly to maintenance problems resulting from iron, calcium, and/or microbial bacteria buildup in the packing materials, which can lead to a deterioration of system performance.

Potential environmental impacts caused by air stripping include the emission of VOCs into the atmosphere. These emissions can be treated with either activated carbon or by incineration. Activated carbon is typically used to polish the discharge water (that is, to remove any trace contaminants) from the air stripper before being released to the sewer.

2.5.1.3.3 Soil washing/soil flushing-Soil washing or flushing is a method that uses water and detergent, solvent, or other chemicals to separate fine particles from the soil. Water or other liquid and the soil are slurried, and fine particles are separated for further treatment and disposal. This process involves use of soil and liquid-handling equipment, and requires additional treatment and/or disposal of the removed particles.

2.5.1.3.4 Vacuum extraction-Vacuum extraction, or soil vapor extraction, is a process that uses negative pressure to remove VOCs from groundwater and soil. Vacuum extraction systems typically consist of extraction wells; a vacuum blower or reciprocating engine, and effluent-handling equipment. This process requires additional treatment of the removed material. The INEL currently has a vacuum extraction system in use, or available for use, with a completed safety analysis, Vapor Vacuum Extraction Safety Analysis Report (INEL undated).

2.5.1.3.5 Activated carbon adsorption-Activated carbon, because of its unique ability to absorb a variety of compounds, is used for air and wastewater treatment. In an operating carbon-adsorption system, water is usually pumped through one or a series of units (columns or 55-gal drums) containing activated carbon. Liquid enters through the top of the unit and exits through the bottom. Operating flow rates for liquids are highly dependent on the amount of suspended solids, but are usually in the range of $2 \mathrm{gal} / \mathrm{min} / \mathrm{ft}^{2}$.

Carbon adsorption is a relatively expensive process. Units must be recharged periodically with either thermally reactivated or virgin carbon, so supply of activated carbon to the adsorption system may be significant.

2.5.1.3.6 Filtration-Filtration is one method of removing suspended solids from contaminated groundwater. The simplest form of filtration is to pass the groundwater through a bed of sand. The suspended solids adhere to the sand particles, and the water continues through the bed. As the filter bed becomes clogged, it must be backwashed by rapid pumping of clean water through the sand bed, opposite the flow of the wastewater. As the sand bed is fluidized, the turbulence breaks off particles attached to the sand, allowing the water to flush suspended solids out of the filter. 
Other types of filter technology include bag, cartridge, and cloth filters, which strain the suspended solids from the water. Once the pressure drop is too high, the filter is removed and cleaned or replaced. These types of filters provide a way of economically removing suspended solids. This method requires additional treatment and disposal of removed contaminants.

2.5.1.3.7 Ion exchange-Ion exchange is a process in which ions held by electrostatic forces to the surface of a solid are exchanged for ions of similar charge in a solution in which the solid is immersed. A typical ion exchange would be the replacement of a sodium ion with a calcium ion, the basis for water softening. Sodium ions can be entirely removed by hydrogen ions, which combine with hydroxide ions to form water.

The disadvantage of remediation by ion exchange is the expense. This method requires additional treatment and disposal of removed contaminants.

2.5.1.3.8 Diffusion membrane separation-This is a potential remedial action technology that is not currently being used, or planned, for environmental remediation of INEL sites. Diffusion membrane separation involves the diffusion of water through a semi-porous membrane of selective permeability. The system operates with a low pressure gradient of approximately $35 \mathrm{lb} / \mathrm{in}^{2}$. The impermeability to halogenated and nonhalogenated hydrocarbons causes these compounds to be retained by the membrane.

Advantages to this technology are low operating pressure and effectiveness in treating oily substances. Additional treatment and disposal of the removed contaminants is required.

2.5.1.3.9 Pervaporation membrane separation-This is a potential remedial action technology that is not currently being used, or planned, for environmental remediation of INEL sites. Like diffusion membrane separation, pervaporation membrane separation is a permeability-selective technology. Contaminated water contacts the membrane on one side and is removed as vapor on the other. This phase change is accomplished by maintaining a vapor pressure on the permeate side that is less than that of the liquid influent side. The effluents of this system are purified groundwater and vapor phase-condensed, concentrated permeate liquid.

Although pervaporation does not require additional air phase offgas treatment as does air stripping, management of the concentrated permeate stream is necessary.

2.5.1.4 Thermal Treatment. Thermal treatment uses high temperature as the principal means of destroying or detoxifying hazardous waste. Thermal treatment methods involve use of newly constructed, temporary, or portable process equipment and related structures.

2.5.1.4.1 Incineration-An incinerator is defined in 40 CFR 260.10 as any closed device using controlled flame combustion that neither meets the criteria for classification as a boiler nor is listed as an industrial furnace. Incineration raises both water (or soil) and contaminants to high temperatures in the presence of oxygen, resulting in carbon dioxide, water, and other side products of combustion. A flame incinerator requires temperatures in the range of $1,500^{\circ}$ to $2,000^{\circ} \mathrm{F}$ to be effective. When waters contain approximately $20 \%$ organics, contaminated water has a self-sustaining burn. At concentrations below this level, auxiliary fuel is required. 
Incinerators, while effective, require an intensive trial burn and permitting process. Groundwater typically contains too small a volume of highly contaminated water, making incineration very expensive. Onsite incineration can be performed when contaminated soil is too dangerous to transport over public roads, or when the nearest landfill is too far away.

2.5.1.4.2 Catalyzed thermal oxjdation-Catalyzed thermal oxidation is the most widely applied thermal method of air treatment. This method is applied to air treatment from vapor extraction systems or offgas treatment from air strippers, using either metals or inorganic acid as the catalyst. Preheated air is passed through the catalyst which, in the presence of oxygen, effects combustion reactions between $500^{\circ}$ and $1,000^{\circ} \mathrm{F}$. The catalyst surface lowers the activation energy required to cause oxygen to react with contaminant hydrocarbons, resulting in water and carbon dioxide.

The advantage of catalytic thermal oxidation is that it does not require supplemental fuel to oxidize influent streams with low concentrations of organics. Lower $\mathrm{NOx}$ and $\mathrm{CO}_{2}$ emissions are a benefit.

2.5.1.4.3 In situ vitrification-During in situ vitrification, large areas of soil are solidified by heating the soil to approximately $1,800^{\circ} \mathrm{C}$. This technology uses electrical energy to heat the sand in soil, which effectively turns the soil into a monolith of glass. The INEL has completed a safety analysis for in situ vitrification, Safety Analysis for the Intermediate Scale Testing of In situ Vitrification (INEL 1991d).

2.5.1.5 Chemical Treatment. Chemical treatment technologies alter the chemical structure of constituents to produce a waste residue less hazardous than the original waste. Altered constituents may be easier to remove from the wastestream. These methods will involve the use of newly constructed, temporary, or portable process equipment and related structures.

2.5.1.5.1 Chemical oxidation/reduction-Chemical oxidation processes in the detoxification of contaminated groundwater involve the exchange of electrons (redox reactions) between chemical constituents and affects a change in the oxidation state of the constituents. This exchange of electrons destroys organic compounds by breaking carbon bonds and creating new compounds. The three most commonly used chemical oxidants are chlorine, ozone, and hydrogen peroxide. Chemical oxidants are used in the treatment of groundwater to break down carbonaceous compounds into $\mathrm{CO}_{2}$ and water. An adequate amount of oxidant is required to affect a complete reaction. To economically facilitate a desired reaction, many reactions require the input of energy in the form of heat or ultraviolet light, or the presence of a catalyst. This technique is typically used in series with an air stripper and/or activated carbon for groundwater treatment.

Limitations of the chemical oxidation/reduction process include the affect of temperature on reaction rates and the long-term effectiveness of the catalysts or energy sources used to stimulate the reactions.

2.5.1.5.2 Precipitation/Flocculation-Chemical precipitation, in conjunction with other treatment methods, is used to adjust the $\mathrm{pH}$ and to reduce the concentration of solids in the waste. Precipitation produces a sludge which must be further treated. 
Particles suspended in water that are not large enough to settle by gravity must be collected by flocculation. The first step in flocculation is to neutralize the charge on all of the particles by adding acid or caustic. Once the charge is neutralized, the particles must be agglomerated by gentle mixing, forming floc. Improvement of the efficiency of flocculation can be achieved by introducing a coagulant such as lime. However, while coagulants improve flocculation, they can be ineffective in water with low concentrations of suspended solids.

2.5.1.5.3 Chemical (licuid phase) oxidation-This is a potential remedial action technology that is not currently being used, or planned, for environmental remediation of INEL sites. In chemical (liquid phase) oxidation, a contaminated liquid stream is mixed with an inorganic acid solution such as phosphoric acid, and heated to temperatures in the range of $250^{\circ}$ to $500^{\circ} \mathrm{F}$. Byproducts of this reaction mechanism are nitrogen, oxygen, carbon monoxide, carbon dioxide, hydrogen, and water. This technology has proven effective in the reduction of pesticides and herbicides.

2.5.1.6 Biological Treatment. Biological treatment technologies involve the addition of bacteria, fungi, or other microorgarisms to alter or destroy hazardous wastes. These processes are highly sensitive to environmental conditions. Biological treatment can be accomplished in situ, or contaminated soil or groundwater can be removed and treated in holding tanks or surface treatment cells. These methods will involve the use of newly constructed, temporary, or portable process equipment and related structures.

2.5.1.6.1 Land farming-For soil contaminated with degradable materials such as diesel fuel, land farming can be used to accelerate the volatilization and biodegradation of the contaminants. In this method, the soil is spread in a thin layer to maximize exposure to air, and nutrients are added. Soil typically is placed on plastic to collect any water, and tilled to mix in nutrients and air.

2.5.1.6.2 Bioreactors-Aerobic reactors magnify the effectiveness of a biological reaction by maximizing the ability of bacteria to produce requisite enzymes which use a specific contaminant as a food and energy source. These reactions are aided by the presence of oxygen supplied to the reactor. One of the easiest units of operation to implement for a groundwater treatment system is an aerated lagoon or basin. An existing pond or tank can be used for the reactor. Contaminated water enters the aerated vessel where bacteria degrade the organics and create new bacteria. Oxygen is supplied to the vessel with a surface aerator or air diffusers. Additional treatment may be required for air emissions or constituents that are not biodegradable.

2.5.1.6.3 Composting--This is a potential remedial action technology that is not currently being used, or planned, for environmental remediation of INEL sites. Composting, an established technology for the treatment of solid hazardous wastes, reduces the biological content of wastes prior to stabilization. Bicdegradation of organic compounds occurs within a compost matrix consisting of contaminated soils and/or sludges mixed with organic carbon sources and bulking agents such as straw, bark, or wood chips. The matrix is divided into piles and placed on lined treatment beds. Microbial degradation of contaminants is maximized by aeration and maintenance of optimum temperature, moisture content, and nutrient levels within the piles. An advantage of composting is that bulking agents can be screened out after completion of the 
composting process and added to a subsequent batch of contaminated soil to be composted. However, composting is time consuming and may extend the closure process.

\subsubsection{D\&D Techniques}

Techniques used for D\&D of equipment and buildings are presented in Table 2-4. The decontamination techniques are separated into two groups: the decontamination techniques being used or planned to be used for existing projects; and some techniques under investigation or development, but potentially available at a later date. Decontamination techniques commonly used involve some method to clean the surface of the equipment and to collect the cleaning agent (typically water) for treatment and disposal. Listed in Table 2-4 are the four common modes used for decommissioning facilities: safe storage; in-place stabilization; decontamination for reuse; and dismantlement. D\&D techniques presently in use typically use standard or modified construction-type equipment, and do not require the installation of new process equipment or structures.

\subsection{Confinement Systems}

Environmental remediation activities are normally conducted outside. Therefore, no confinement system is associated with these type of activities. The safety documentation for a specific activity should include any confinement systems associated with the activity. D\&D activities are associated with shutdown facilities and may have confinement systems associated with their designs. Any available system should be described in this section. In addition to confinement systems associated with the facility, a surveillance and maintenance program is developed for D\&D activities to ensure adequate containment of contamination, and to provide physical safety and security controls and regulated surveillance to maintain the facilities in a manner that will minimize potential hazards to the public, workers, and the environment.

The surveillance and maintenance program is required by DOE $5820.2 \mathrm{~A}$, Chapter V. This program activity manages the inspection and maintenance of surplus facilities identified for $D \& D$ and assures compliance with all applicable safety, environmental, and procedural standards while these facilities are under D\&D program control. Elements of the D\&D surveillance and maintenance program are as follows:

- Surveillance and maintenance planning to accomplish the appropriate integration of facility conditions, surveillance frequencies, security requirements, routine maintenance, and major facility repair

- Performance and documentation of periodic inspections at each surplus facility

- Deficiency control system that provides for the prioritization, tracking, resolution, and documentation of identified deficiencies

- Performance of maintenance, repair, and cleanup tasks required to correct deficiencies and complete routine scheduled maintenance. 
Table 2-4. D\&D techniques.

Technique/mode

Description

Decontamination Techniques in-use or Planned:

Water/chemical flushes Large amounts of water used, with or without chemicals being added, to remove any surface contamination.

Steam jet cleaning Involves use of high-pressure steam to clean the surface with or without chemicals being added.

Manual cleaning

Water used, with or without chemical additives, and stiff bristle brushes to manually scrub the surface of the contaminated material.

Carbon dioxide blasting An abrasive method using carbon dioxide pellets as abrasive media.

Scabbling and spalling Machinery used that mechanically removes top layer of material such as concrete, along with surface contaminants.

Sandblasting Sand used as abrasive to remove surface layers.

Decontamination Techniques Under Investigation/Development:

Strippable coating

Vibratory

Hydroblasting

Abrasion

Electropolishing

Light ablation

Foams and gels

\section{Decommissioning Modes}

Safe storage

In-place stabilization

Decontamination for reuse

Dismantlement
Coating system, applied before facility becomes contaminated, and easily removed along with surface contaminants.

Vibratory action used to dislodge particles from surface.

Extremely high-pressure water used to remove surface layer contaminants.

Abrasive material (sand, $\mathrm{CO}_{2}$ pellets, glass beads), propelled against contaminated surface at high velocity to remove contaminants and some of substrate.

Object being decontaminated serves as anode in electrochemical process which dissolves surface material, including contaminants.

High energy light source (ultraviolet, laser) used to volatize surface layer contaminants.

Specially formulated foams and gels used as cleaning agents.

Contaminated material stored in location designated as safe for storage of contaminated material. Used when contaminated material cannot be safely decontaminated, but can be moved to safe location. Method involves volume reduction, if possible.

Immobilization or encapsulation of contaminants to eliminate dispersion of contaminants. Method used when contaminated material cannot be decontaminated or moved to safe storage location.

Removal of contamination to "clean" condition suitable for reuse.

Dismantlement of structure and separate disposal of contaminated and non-contaminated material. Method involves volume reduction, if possible. 
Hazards to workers, the public, and the environment may be present at a surplus facility awaiting D\&D. The hazards depend on factors including type and amount of contaminant present; medium in which contaminant is present; condition of facility; present use of facility; and location of workers engaged in day-to-day or periodic activities. Health hazards will be identified in the activity-specific safety analysis documentation but can include the presence of ionizing radiation; airborne particulates of toxic materials such as heavy metals; VOCs in the atmosphere; flammable substances; PCBs; and physical hazards such as open excavations and equipment or buildings in disrepair. Environmental hazards can include the presence of toxic contaminants in liquids or airborne contaminated soil or debris. Table 2-5 provides some examples of standard surveillance techniques.

\subsection{Safety Support Systems}

Engineered safety features and safety class structures, systems, and components are not expected to be required for environmental remediation and D\&D activities that are classified as Hazard Category 3 or below. For these environmental remediation and D\&D activities within the scope of the BSAF, the unmitigated release of the available inventory of radioactive and/or hazardous material has the potential for only significant localized consequences (see Chapter 3 ).

Structures, systems, and components important to worker safety may be required for environmental remediation and D\&D activities. Standard industrial controls apply for areas such as electrical and fire safety. Design, operation, maintenance, and surveillance of structures, systems, and components important to worker safety are described in Chapters 9 and 10. A listing of codes and standards that may be applicable is provided in Chapter 21, which includes DOE 6430.1A and the DOE-ID Architectural Engineering Standards (DOE-ID 1992). Table 2-6 lists design features important to environmental remediation and D\&D activities at the INEL that may be required depending on the hazards to which workers may be exposed.

Table 2-5. Examples of surveillance techniques for surplus facilities.

\begin{tabular}{ll}
\hline \multicolumn{1}{c}{ Hazard } & \multicolumn{1}{c}{ Surveillance technique } \\
\hline Radioactivity & - Surface contamination swipes/swabs \\
& - Handheld radiation detector \\
& - Continuous area monitors \\
& - Remote area monitors \\
Chemical & - Organic vapor detectors (photoionization, flame ionization) \\
& - Laboratory analysis of samples \\
& - Personal air sampling pumps (for example, lead, silica dust) \\
& - Combination gas detector (oxygen percentage, lower explosive limit) \\
Industrial & - Draeger tubes and hand pump \\
& - Noise: noise dosimeter/sound level monitor \\
& - Heat/cold: field measurements and observations \\
& - Visual inspection of work site and equipment before and during work activities \\
\hline
\end{tabular}


Table 2-6. Examples of design features important to worker protection.

\begin{tabular}{cl}
\hline & \multicolumn{1}{c}{ Design feature } \\
\cline { 2 - 2 } Hazard & \multicolumn{1}{c}{ Item } \\
\hline Radioactivity & Shielding \\
& Containment/confinement \\
& Monitors \\
Chemical & Ventilation \\
& Containment/confinement \\
& Monitors \\
\hline
\end{tabular}

\subsection{Utility Distribution Systems}

This section should describe the utilities required to perform environmental remediation and D\&D activities. The major focus should be describing those utilities required for the safety of personnel, the public, and the environment. The following utilities are potentially necessary to support environmental remediation and D\&D activities:

- Telephone service

- Water service/supply

- Electrical distribution/electrical generators/emergency electrical power.

\subsection{Auxiliary Systems and Support Facilities}

Environmental remediation and D\&D activities require the support of INEL facilities and services. Supporting facilities necessary for environmental remediation and D\&D activities include waste storage, treatment, and disposal facilities (onsite and offsite), including the Waste Experimental Reduction Facility and RWMC, and personnel support facilities for sanitation, staging areas, and offices. Services required in support of environmental remediation and D\&D activities include fire protection, security, emergency response personnel and equipment, and transportation of radioactive, hazardous, and solid waste. Facilities and services potentially necessary to support environmental remediation and D\&D activities include the following:

- Decontamination unit (trailer)

- Radio communications

- Fire Brigade

- Respirable air supply

- Emergency egress considerations

- Confined space testing services

- Underground utility locating services. 


\subsection{References}

Department of Energy, Idaho Operations Office (DOE-ID 1992), DOE-ID Architectural Engineering Standards, DOE-ID, Idaho Falls, ID.

Department of Energy, Idaho Operations Office (DOE-ID 1993), Draft INEL EIS Environmental Restoration Program Assessment, May 14, 1993, Jason Associates Corporation, DOE-ID, Idaho Falls, ID.

EG\&G Idaho, Inc. (EG\&G 1986), Safety Analysis Report for the TAN-607 Complex, EG\&G, Idaho Falls, ID.

EG\&G Idaho, Inc. (EG\&G 1989), Research Investigation/Feasibility Study Work Plan for the Subsurface Disposal Area, Radioactive Waste Management Complex at the INEL (Draft), EG\&G, Idaho Falls, ID, EGG/WM-8776.

EG\&G Idaho, Inc. (EG\&G 1993a), Waste Stream Projections for Environmental Restoration at the Idaho National Engineering Laboratory, EG\&G, Idaho Falls, ID, June, 1993, DOE/DD-10417.

EG\&G Idaho, Inc. (EG\&G 1993b), Environmental Restoration Program Major System Acquisition Baseline, EG\&G, Idaho Falls, ID, DOE/ID-0000.

EG\&G Idaho, Inc. (EG\&G 1993c), INEL Technical Site Information, EG\&G, Idaho Falls, ID, DOE-ID 10401.

EG\&G Idaho, Inc. (EG\&G 1995), INEL D\&D Long-Range Plan, EG\&G, Idaho Falls, ID, DOE-ID, EGG-WM-10924, Rev. 10, August 1995.

Idaho National Engineering Laboratory (undated), Vapor Vacuum Extraction Safety Analysis Report, INEL, Idaho Falls, ID.

Idaho National Engineering Laboratory (INEL 1987), Consent Order and Compliance Agreement, INEL, Idaho Falls, ID., July 10, 1987.

Idaho National Engineering Laboratory (INEL 1991a), Federal Facility Agreement and Consent Order, INEL, Idaho Falls, ID., December 4, 1991.

Idaho National Engineering Laboratory (INEL 1991b), Action Plan for Implementation of the Federal Facility Agreement and Consent Order, December 4, 1991, INEL, Idaho Falls, ID [part of FFA/CO (INEL 1991a)].

Idaho National Engineering Laboratory (INEL 1991c), TAN Hot Cell Complex Final Safety Analysis Report, INEL, Idaho Falls, ID.

Idaho National Engineering Laboratory (INEL 1991d), Safety Analysis for the Intermediate Scale Testing of In Situ Vitrification, INEL, Idaho Falls, EGG-WM-8082, Rev. 1. 
Idaho. National Engineering Laboratory (INEL 1992a), Safety Analysis Report for the TAN-607, Decontamination Facilities, INEL, Idaho Falls, ID.

Idaho National Engineering Laboratory (INEL 1992b), Safety Analysis Report for the D\&D of the Hot Laundry Facility, INEL, Idaho Falls, ID, WM-ERP-92-017.

Idaho National Engineering Laboratory (INEL 1992c), Safety Analysis Report for the Auxiliary Reactor Area I, INEL, Idaho Fialls, ID, WM-ERP-92-019, Rev. 0.

Idaho National Engineering Laboratory (INEL 1992d), Safety Analysis Report for the Auxiliary Reactor Area (ARA-II) at the INEL, Idaho Falls, ID, WM-ERP-91-006, Rev. 1.

Idaho National Engineering Laboratory (INEL 1992e), Safety Analysis Report for the Auxiliary Reactor Area (ARA-III) at the INEL, INEL, Idaho Falls, ID, WM-ERP-91-003, Rev. 2

Idaho National Engineering Laboratory (INEL 1992f), Safety Analysis Report for the D\&D of the BORAX-V Facility, INEL, Idaho Falls, ID, ER-93-024, Rev. 0.

Idaho National Engineering Laboratory (INEL 1993a), Waste Reduction Operations Complex Portable Water Treatment Unit Auditable Safety Analysis, INEL, Idaho Falls, ID, ER\&WM-WROC-031-93.

Idaho National Engineering Laboratory (INEL 1993b), Waste Reduction Operations Complex Portable Water Treatment Unit Operational/Technical Safety Requirements, INEL, Idaho Falls, ID, ER\&WM-WROC-032-93.

C. E. Klassy and D. E. Keller, Auditable Safety Analysis for the Storage and Handling of the EBR-I NaK, EGG-ER-11160, March 1994.

Morrison Knudsen-Ferguson of Idaho Company (MK-FIC 1993a), Auditable Safety Analysis for Test Area North (TAN) Interim Action Groundwater Treatment Facility Operable Unit 1-07A, MK-FIC, Idaho Falls, ID, May 31, 1993, MK-FIC-ERP-No. 01.07A1.1.110.01.

Morrison Knudsen-Ferguson of Idaho Company (MK-FIC 1993b), Auditable Safety Analysis for Test Reactor Area Warm Waste Pond Interim Action Operable Unit 2-10, MK-FIC, Idaho Falls, ID, MK-FIC-ERP-No. 12.010.1.2.110.01.

Morrison Knudsen-Ferguson of Idaho Company (MK-FIC 1993c), Auditable Safety Analysis for Interim Action to Clean Up Unexploded Ordnance Locations at the Idaho National Engineering Laboratory, MK-FIC, Idaho Falls, ID, MK-FIC-ERP-No. 10.005.1.1.110.01.

Westinghouse Idaho Nuclear Company (WINCO 1993), Idaho Chemical Processing Plant Technical Site Information, WINCO, Idaho Falls, ID, WIN-327. 


\section{HAZARD AND ACCIDENT ANALYSES}

\subsection{Introduction}

Most chapters of the Baseline Safety Analysis File (BSAF) provide information that can be directly used or simply augmented with activity-specific information to satisfy the safety documentation requirements of Department of Energy (DOE) orders and standards. However, Chapter 3 differs. This chapter outlines the DOE-EM-STD-3009-94 (DOE 1994b) format for Chapter 3 and provides guidance as to the type of information specific to the Idaho National Engineering Laboratory (INEL) Environmental Restoration (ER) program activities (remediation and D\&D activities) in each section. This guidance is based on DOE-EM-STD-5502-94 (DOE 1994a) and DOE-STD-1027-92 (DDE 1992) and can be used to document the following:

- $\quad$ Nuclear Facility, Hazard Category 3 (DOE Order 5480.23, Nuclear Safety Analysis Reports, March 10,1994), required safety documentation, which is a safety analysis report (SAR)

- $\quad$ Nonnuclear Facility, "Low" Hazard (DOE Order 5481.1B, Safety Analysis and Review System, May 19, 1987), required safety documentation, which is a SAR or an auditable safety analysis (ASA)

- Radiological facility, required safety documentation, which is an ASA.

However, some of the text can be used directly in the activity-specific safety documentation to provide bases and explanatory information.

In addition, criteria are provided that will assist in classifying the various activities according to DOE-STD-1027-92 (DOE 1992) and DOE-EM-STD-5502-94 (DOE 1994a).

\subsection{Requirements}

The following standards, regulations, and DOE orders are applicable to this chapter:

- 29 CFR 1910, "Occupational Safety and Health Standards"

- 29 CFR 1926, "Safety and Health Regulations for Construction"

- $\quad 40$ CFR 302, "Designation, Reportable Quantities, and Notification"

- $\quad 40$ CFR 355, "Emergency Planning and Notification"

- DOE 5400.5, "Radiation Protection of the Public and the Environment," February 8, 1990

- DOE 5480.6, "Safety of Department of Energy-Owned Nuclear Reactors," September 23, 1986 
- DOE 5480.7A, "Fire Protection," February 17, 1993

- DOE 5480.11, "Radiation Protection for Occupational Workers," June 17, 1992

- DOE 5480.23, "Nuclear Safety Analysis Reports," March 10, 1994

- DOE 5481.1B, "Safety Analysis and Review System," May 19, 1987

- DOE-STD-1027-92, "Hazard Categorization and Accident Analysis Techniques for Compliance with DOE Order 5480.23, Nuclear Safety Analysis Reports," December 1992

- DOE-STD-3009-94, "Preparation Guide for U.S. Department of Energy Nonreactor Nuclear Facility Safety Analysis Reports," July 1994

- DOE-EM-STD-5502-94, "Hazard Baseline Documentation," August 1994.

\subsection{Hazard Analysis}

"A hazard is a source of danger (that is, a material, energy source, or operation) with the potential to cause illness, injury, or death to personnel or damage to a facility or to the environment, without regard for the likelihood or credibility of accident scenarios or consequence mitigation," as defined in DOE Order 5480.23. Hazard analysis is the initial step in the process of identifying and evaluating potential hazards in a facility. The analysis is used to identify the hazardous chemical and/or radioactive material in a facility, the energy sources and initiating events that could lead to the potential consequences of an accident, and the release mechanisms for the source term generated by the initiating events and released due to the energy sources. From these results, the facility hazards can either be further analyzed using acceptable accidentevaluation techniques or be established as acceptable risks controlled or reduced through the use of DOE-required occupational safety and health (OSH) programs.

\subsubsection{Methodology}

This section in the activity-specific safety document should present the methodology that is used to identify, characterize, and perform a systematic evaluation of hazards associated with the specific activity.

3.3.1.1 Hazard Identification. This subsection in the activity-specific safety document should present the method used by analysts to identify potential hazards and energy sources (in terms of quantity, form, and location) associated with the specific activity. The methodology may be as simple as using a checklist (as illustrated in Section 3.3.2.1) or using more complicated detailed analysis techniques. The important aspect is to use a method that will ensure completeness in identifying worker safety issues, including standard industrial hazards. Possible sources of information concerning hazards typically encountered in ER activities include, but are not limited to, fire hazard analyses, health and safety plans, job safety analyses, occurrence reporting histories, etc. 
This subsection should also include inventory information for hazardous chemical, radiological hazards, or both. Possible sources of inventory information include, but are not limited to, historical data on contamination levels and releases, soil sampling, well drilling, water sampling from wells, ponds, or tanks, direct radiation surveys, and/or scraping and wipe sampling. The interpretation of the data used to derive conservative inventory values should also be provided.

3.3.1.2 Hazard Evaluation. This subsection in the activity-specific safety document should present, in summary fashion, the basic approach used to postulate the consequence and likelihood estimates used in the hazard evaluation. Detailed guidance should be referenced. Additionally, any screening logic used for binning, accidents should be presented.

The appropriateness of the overall methods used to evaluate hazards should be presented and justified. This justification should focus on the reason for selecting a technique, not on describing the standard analysis methods, such as hazards and operability studies.

\subsubsection{Hazard Analysis Results}

This section in an activity-specific safety document should present the data gathered for the hazard analysis, the justification for the activity classification, and the evaluation of the hazards to determine accident scenarios that could cause exposure to radionuclides and hazardous chemicals above guidance levels.

3.3.2.1 Hazard Identification. Typically, potential hazards to workers, the public, and the environment for most ER activities can be systematically conducted by using two checklists, presented in Tables 3-1 and 3-2. The checklists identify occupational hazards, material hazards, and energy sources that result from ER activities. The checklists can be reproduced in the activity-specific safety analysis document with the potential hazards identified with a "yes" in Column 2. Those not associated with the activity are marked with a "no." Those governed by an OSH standard are identified by listing the standard in Column 4. The major OSH standards cited in Table 3-1 are the Code of Federal Regulations (CFR) Title 29 Section 1910, "Occupational Safety and Health Standards," and Section 1926, "Safety and Health Regulations for Construction."

To ensure that the identified hazards include relevant DOE experience, two primary databases should be searched: the Safety Performance Measurement System [SPMS (DOE 1990)] and the Occurrence Reporting and Processing System [ORPS (DOE-ID 1991a)]. These systems are maintained by the System Safety Development Center, located at the INEL, under guidance of DOE's Office of Nuclear Energy. The SPMS (DOE 1990) consists of several modules including the Computerized Accident/Incident Reporting System (CAIRS) module and the Unusual Occurrence Report (UOR) module. The CAIRS is an automated system for retrieving DOE-wide accident data. The UOR module is a database consisting of UORs generated between January 1981 and September 1990. After 1990, UORs were categorized as Occurrence Reports and recorded and tracked by ORPS (DOE-ID 1991a). 
Table 3-1. Occupational hazard analysis checklist.

\begin{tabular}{|c|c|c|c|}
\hline Hazard & Applicable & Explanation & DOE-prescribed OSH standards \\
\hline $\begin{array}{l}\text { High voltage } \\
(2600 \mathrm{~V})\end{array}$ & Yes/No & $\begin{array}{l}\text { Power supply lines or electrical } \\
\text { equipment at the ER site }\end{array}$ & 29 CFR 1910, Subpart S \\
\hline $\begin{array}{l}\text { Low voltage } \\
(<600 \mathrm{~V})\end{array}$ & Yes/No & $\begin{array}{l}\text { Power supply lines or electrical } \\
\text { equipment at the ER site }\end{array}$ & 29 CFR 1910, Subpart S \\
\hline $\begin{array}{l}\text { Flammable gases, } \\
\text { liquids, dusts }\end{array}$ & Yes/No & $\begin{array}{l}\text { Contained in vessels, piping, or } \\
\text { used in decontamination or at } \\
\text { site }\end{array}$ & $\begin{array}{l}29 \text { CFR } 1910.106, .107, .108, .110, .111 \\
.120, .144, .1200 ; 29 \text { CFR } 1926.152\end{array}$ \\
\hline Explosive materials & Yes/No & Explosives used at site & $\begin{array}{l}29 \text { CFR 1910.109; DOE Explosive Safety } \\
\text { Manual (DOE 1991); } 40 \text { CFR } \\
\text { Subchapter C }\end{array}$ \\
\hline Cryogenic systems & Yes/No & $\begin{array}{l}\text { Used in decontamination or at } \\
\text { site }\end{array}$ & $\begin{array}{l}\text { No DOE-prescribed standards clearly } \\
\text { address cryogenics }\end{array}$ \\
\hline $\begin{array}{l}\text { High temperature } \\
\left(2125^{\circ} \mathrm{F} \text { at contact }\right. \\
\left.\text { or } 203^{\circ} \mathrm{F}\right)\end{array}$ & Yes/No & $\begin{array}{l}\text { Used in decontamination or at } \\
\text { site }\end{array}$ & $\begin{array}{l}\text { American Society of Mechanical Engineers } \\
\text { Boiler and Unfired Pressure Vessel Code }\end{array}$ \\
\hline $\begin{array}{l}\text { High pressure ( } 225 \\
\text { psig for gas or vapor } \\
\text { or } \geq 200 \text { psig for } \\
\text { liquids) }\end{array}$ & Yes/No & $\begin{array}{l}\text { Used in decontamination or at } \\
\text { site }\end{array}$ & $\begin{array}{l}\text { American Society of Mechanical Engineers } \\
\text { Boiler and Unfired Pressure Vessel Code }\end{array}$ \\
\hline $\begin{array}{l}\text { Inert and low-oxygen } \\
\text { atmospheres }\end{array}$ & Yes/No & $\begin{array}{l}\text { At vessel entry and in } \\
\text { excavations }\end{array}$ & $\begin{array}{l}29 \text { CFR } 1910.120, .252, .1200 ; 29 \text { CFR } \\
1926.651\end{array}$ \\
\hline Toxic substances & Yes/No & $\begin{array}{l}\text { Identified in material inventory; } \\
\text { used in decontamination or at } \\
\text { site }\end{array}$ & $\begin{array}{l}29 \text { CFR 1910.120, .1200, Subpart Z; } \\
29 \text { CFR 1926.353; American Conference } \\
\text { of Governmental Industrial Hygienists } \\
\text { (ACGIH) Threshold Limit Values (TLVs) } \\
\text { (ACGIH 1992) }\end{array}$ \\
\hline Nonionizing radiation & Yes/No & $\begin{array}{l}\text { Use of lasers, infrared heaters, } \\
\text { or radio-frequency equipment in } \\
\text { decontamination or at site }\end{array}$ & $\begin{array}{l}29 \text { CFR 1910.97; ACGIH TLVs } \\
\text { (ACGIH 1992) }\end{array}$ \\
\hline $\begin{array}{l}\text { High-intensity } \\
\text { magnetic fields }\end{array}$ & Yes/No & $\begin{array}{l}\text { Used in decontamination or at } \\
\text { site }\end{array}$ & ACGIH TLVs (ACGIH 1992) \\
\hline High noise levels & Yes/No & $\begin{array}{l}\text { Generated around operating } \\
\text { equipment or during gas or } \\
\text { liquid releases during } \\
\text { decontamination or at site }\end{array}$ & $\begin{array}{l}29 \text { CFR 1910.95, .1200; } 29 \text { CFR } 1926.52 \text {; } \\
\text { ACGIH TLVs (ACGIH 1992) }\end{array}$ \\
\hline $\begin{array}{l}\text { Mechanical and } \\
\text { moving equipment } \\
\text { dangers }\end{array}$ & Yes/No & $\begin{array}{l}\text { Exposure around equipment and } \\
\text { vehicles used in decontamination } \\
\text { or at site }\end{array}$ & $\begin{array}{l}29 \text { CFR 1910.147, .211-.222; } 29 \text { CFR } \\
1926 \text {, Subpart } \mathrm{W} \\
\text { Working at heights }\end{array}$ \\
\hline Working at heights & Yes/No & $\begin{array}{l}\text { Exposure on structures or high } \\
\text { working surfaces at site }\end{array}$ & $\begin{array}{l}29 \text { CFR } 1910.25, .28 ; 29 \text { CFR } 1926.951 \text {, } \\
.451\end{array}$ \\
\hline Excavation & Yes/No & $\begin{array}{l}\text { Exposure around excavations at } \\
\text { site }\end{array}$ & 29 CFR 1926, Subpart P \\
\hline
\end{tabular}


Table 3-1. (continued).

\begin{tabular}{|c|c|c|c|}
\hline Hazard & Applicable & Explanation & DOE-prescribed OSH standards \\
\hline $\begin{array}{l}\text { Material-handling } \\
\text { dangers }\end{array}$ & Yes/No & Exposure at site & $\begin{array}{l}29 \text { CFR 1910.120, } .176, .178-.182 ; 29 \\
\text { CFR 1926.953; DOE Hoisting and Rigging } \\
\text { Manual (DOE 1993) }\end{array}$ \\
\hline Pesticides & Yes/No & Usted at site & 29 CFR 1910.1200 \\
\hline $\begin{array}{l}\text { Temperature } \\
\text { extremes (for } \\
\text { example, high and } \\
\text { low temperatures } \\
\text { during activities) }\end{array}$ & Yes/No & $\begin{array}{l}\text { Exposure from environmental } \\
\text { temperature extremes at site. } \\
\text { Exposure from personal } \\
\text { protective equipment layers }\end{array}$ & $\begin{array}{l}29 \text { CFR 1910.120, .1200; ACGIH TLVs } \\
\text { (ACGIH 1992) }\end{array}$ \\
\hline $\begin{array}{l}\text { Inadequate } \\
\text { illumination }\end{array}$ & Yes/No & $\begin{array}{l}\text { Activities within enclosed } \\
\text { structures or if little daylight at } \\
\text { site }\end{array}$ & $\begin{array}{l}29 \text { CFR } 1910.37, .68, .110, .120, .177 \\
.179, .219, .303 ; 29 \text { CFR } 1926.26\end{array}$ \\
\hline Construction & Yes/No & Exposure at site & 29 CFR 1926 \\
\hline
\end{tabular}

Table 3-2. Material and energy source hazard analysis checklist.

\begin{tabular}{|c|c|c|}
\hline Hazard & Applicable & Explanation \\
\hline Radioactive & Yes/No & Iclentified in material inventory and exposure at activity site \\
\hline Fissionable or fissile & Yes/No & $\begin{array}{l}\text { Iclentified material inventory greater than DOE-STD-1027-92 (DOE 1992) } \\
\text { minimum critical fissile mass limits }\end{array}$ \\
\hline Alkali metal & Yes/No & $\begin{array}{l}\text { Iclentified in material inventory and exposure at activity site; incompatible } \\
\text { mixtures at site (sodium, sodium potassium, and lithium, for example) }\end{array}$ \\
\hline Corrosive & Yes/No & $\begin{array}{l}\text { Iclentified in material inventory and exposure at activity site; incompatible } \\
\text { mixtures at site (acids, caustics, organic solvents, for example) }\end{array}$ \\
\hline Natural phenomena & Yes/No & Exposure at site; contributes to release of radioactive or hazardous materials \\
\hline Fire & Yes/No & Exposure at site; contributes to release of radioactive or hazardous materials \\
\hline Interfaces & Yes/No & Equipment used to transport material from place to place; exposure at site \\
\hline Waste disposal & Yes/No & Incompatible wastes and container materials \\
\hline Maintenance & Yes/No & $\begin{array}{l}\text { Maintenance requirements outside of as-low-as-reasonably-achievable } \\
\text { philosophy }\end{array}$ \\
\hline Security & Yes/No & $\begin{array}{l}\text { Accidental discharge of weapons during inspection or surveillance contributing } \\
\text { to release of radioactive or hazardous materials }\end{array}$ \\
\hline
\end{tabular}

The databases can be searched using key words, which is useful in determining whether other DOE sites performing similar activities have had reportable problems. Representative events in the DOE databases that are potentially applicable to ER activities are identified in Table 3-3. Based on these events, the most common hazards for ER workers are industrial safety hazards, worker contamination, and. release of radioactive and nonradioactive hazardous materials. However, none of these releases resulted in significant environmental damage or significant localized exposures. 
Table 3-3. Potential database events applicable to ER activities.

\begin{tabular}{|c|c|c|c|}
\hline Database & Report number & Event description & Safety significance \\
\hline \multirow[t]{2}{*}{ ORPS } & $\begin{array}{l}\text { RL-WHC-TPLANT- } \\
\text { 1992-0018 }\end{array}$ & $\begin{array}{l}\text { Site: Hanford, T-Plant facility. Pinhole failure in } \\
\text { lower area of } 55 \text {-gal steel drum resulted in release } \\
\text { of potentially hazardous waste exceeding } \\
\text { state-specified quantities. }\end{array}$ & $\begin{array}{l}\text { Environmental } \\
\text { release }\end{array}$ \\
\hline & $\begin{array}{l}\text { ORO-MMES-PORT } \\
\text { STEMG-1992-0001 }\end{array}$ & $\begin{array}{l}\text { Site: Portsmouth Gaseous Diffusion Plant, } \\
\text { Uranium enrichment facility. Five individuals } \\
\text { contaminated with beta contamination during } \\
\text { radioactive solid waste transfer activities. }\end{array}$ & $\begin{array}{l}\text { Personnel } \\
\text { contamination }\end{array}$ \\
\hline \multirow[t]{4}{*}{ UOR } & 1953 & $\begin{array}{l}\text { Site: INEL, Chemical Processing Plant. Eight } \\
\text { subcontractor employees contaminated after } \\
\text { handling contaminated tools. }\end{array}$ & $\begin{array}{l}\text { Personnel } \\
\text { contamination }\end{array}$ \\
\hline & 5524 & $\begin{array}{l}\text { Site: Oak Ridge National Laboratory, X-10 facility. } \\
\text { Asbestos accidently released during removal of } \\
\text { insulated pipe. Asbestos spread over } 40 \text {-square foot } \\
\text { area of facility; approximately five additional people } \\
\text { possibly exposed to unknown concentrations of } \\
\text { asbestos fibers. }\end{array}$ & $\begin{array}{l}\text { Personnel exposure } \\
\text { to hazardous } \\
\text { materials }\end{array}$ \\
\hline & 5026 & $\begin{array}{l}\text { Site: Martin Marietta (Paducah), PAGPP facility. } \\
\text { Small quantity of mixed hazardous material released } \\
\text { when drum fell during transport with forklift. }\end{array}$ & $\begin{array}{l}\text { Environmental } \\
\text { release }\end{array}$ \\
\hline & 869 & $\begin{array}{l}\text { Site: Los Alamos National Laboratory, TA-21-257 } \\
\text { facility. Chemical reaction occurred in treatment } \\
\text { facility when operator accidentally transferred } \\
\text { chemical precipitate to tank containing acid. } \\
\text { Chemical reaction resulted in foam released } \\
\text { through vent line and through high-efficiency } \\
\text { particulate air (HEPA) filter contaminating side of } \\
\text { building with } \mathrm{U}, \mathrm{Pu} \text {, and Am. }\end{array}$ & $\begin{array}{l}\text { Environmental } \\
\text { release and } \\
\text { contamination }\end{array}$ \\
\hline \multirow[t]{2}{*}{ CAIRS } & 87005 & $\begin{array}{l}\text { Site: EG\&G Mound Applied Technologies, SM } \\
\text { facility. During D\&D activities, employee killed } \\
\text { after falling through unguarded hole in mezzanine. }\end{array}$ & Personnel injury \\
\hline & 92008 & $\begin{array}{l}\text { Site: Martin Marietta, K- } 25 \text { facility. Large } \\
\text { polyethylene tank being installed in bermed area } \\
\text { when lifting strap broke and tank fell on employee. } \\
\text { Employee died five days later. }\end{array}$ & Personnel injury \\
\hline
\end{tabular}

An inventory of radioactive and hazardous materials (based on best available information) that may be encountered during an ER activity needs to be included in this or the following section. Hazardous materials used as part of the ER activity should be included in the inventory. The quantity, form (e.g., powder, metal, sludge, gas, etc.), and location (if more than one site is addressed or if the contaminants are in separate locations at the same site) of the radioactive and hazardous materials should be identified. 
3.3.2.2 Hazard Classification. Hazard classification is determined by identifying both the radioactive and hazardous material inventories involved with the specific ER activity and comparing these inventories to established guidelines in the following DOE orders, DOE standards, and CFRs: DOE Order 5480.23, DOE Order 5481.1B, DOE-ID Supplemental Directive 5481.1B (DOE-ID 1991b), DOE-STD-1027-92 (DOE 1992), DOE-EM-STD-5502-94 (DOE 1994a), 29 CFR 1910.119, 40 CFR 302, and 40 CFR 355. A contaminant is compared to the appropriate guideline; however, is more than one contaminant is present, then a ratio is calculated to determine the classification.

The classification process is detailed in Figure 3-1, which has been taken directly from DOE-EM-STD-5502-94 (DOE 199.4a). The activity-specific radionuclide inventory is compared to threshold quantities (TQs) established in Attachment 1 of DOE-STD-1027-92 (DOE 1992) and to the reportable quantities (RQs) specified in 40 CFR 302.4, Appendix B. Activities whose radiological material inventory meets or exceeds the TQ levels in Attachment 1 of DOE-STD1027-93 (DOE 1992) are classified as "Nuclear Facilities" with a hazard category of 1, 2, or 3 (defined in Table 3-4) and require safety documentation written in accordance with requirements established in DOE Order 5480.23. BSAF does not cover activities determined to be Hazard Category 1 or 2 . It does cover activities determined to be Hazard Category 3 .

Activities with radiological material inventories below the Hazard Category 3 TQ and above the RQ value presented in Appendix B of 40 CFR 302.4 are classified as "radiological facilities." Safety analyses must be performed and the results either incorporated in the activity's Health and Safety Plan or in an Auditable Safety Analysis report as shown in Figure 3-1. Activities with radiological material inventories below the RQ values are considered "other industrial facilities," for which only a health and safety plan is required.

Activities identified with hazardous chemicals need to compare the inventory against the following guidance levels: RQs established in 40 CFR 302.4, TQs established in 29 CFR 1910.119, or threshold planning quantities (TPQs) established in 40 CFR 355. Activities whose hazardous material inventory is only hazardous chemicals (levels of radionuclides are below the $\mathrm{RQ}$ ) and meet or exceed the RQ, TQ, or TPQ levels are classified as "nonnuclear facilities" and are governed by safety guidelines established in DOE Order 5481.1B. Hazard categories, defined in DOE Order 5481.1B and DOE-ID SD 5481.1B (DOE-ID 1991b) and repeated in Table 3-4 under Nonnuclear Facilities, are used to classify the facilities according to the consequences of credible accidents resulting in a release of hazardous material. The BSAF covers only those activities determined to be a "low" hazard.

Safety documentation for activities with both radiological and hazardous chemicals will be governed by the most restrictive guidelines. For instance, safety documentation for Category 3 activities with identified chemical inventories meeting BSAF requirements (low hazard) will meet requirements of DOE Order 5480.23. Safety documentation for radiological activities with chemical inventories that meet or exceed the TQ or TPQ will meet requirements of DOE Order 5481.1B. 


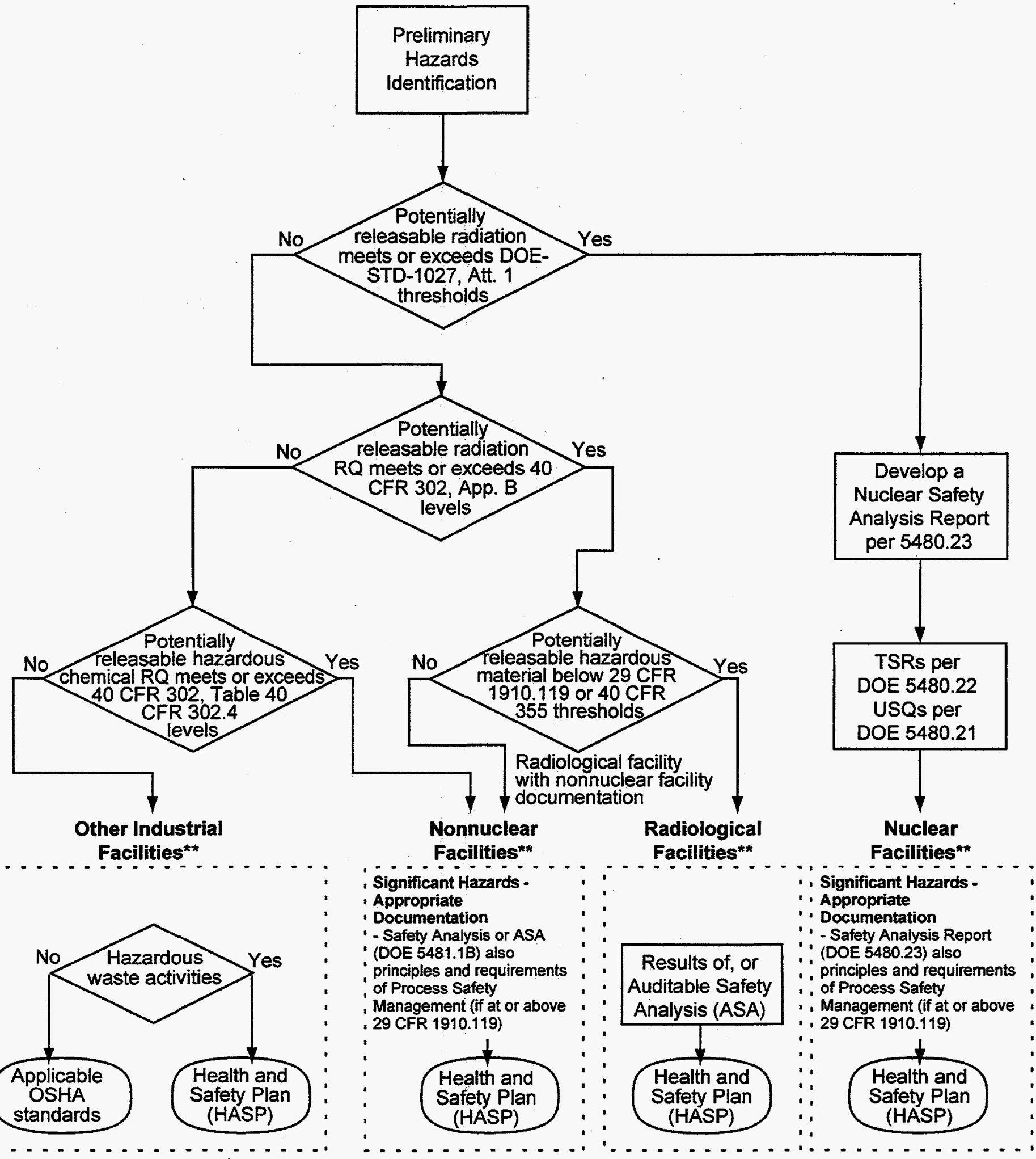

** Other types of safety and health hazard identification and control documentation may be necessary, such as construction safety

ML5080 requirements, Chemical Hygiene Plans, and HazCom. All facilities with hazardous waste activities require a HASP as defined in 29 CFR $1910.120(a)$.

Figure 3-1. EM hazard baseline documentation process. 
Table 3-4. Hazard classification standards.

\begin{tabular}{|c|c|c|}
\hline Hazard categories & Classification limits & Classification criteria \\
\hline \multicolumn{3}{|c|}{ Nuclear Facilities (DOE Order 5480.23) } \\
\hline Hazard Category 1 & Hazard Category A Reactors (DOE 5480.6) & $\begin{array}{l}\text { Hazard analysis shows potential for significant } \\
\text { offsite consequences }\end{array}$ \\
\hline Hazard Category 2 & $\begin{array}{l}\text { Table A.1 Cat } 2 \text { TQ (DOE-STD-1027-92) } \\
\text { (DOE 1992), Criticality events }\end{array}$ & $\begin{array}{l}\text { Hazard analysis shows potential for significant } \\
\text { onsite consequences }\end{array}$ \\
\hline Hazard Category 3 & $\begin{array}{l}\text { Table A.1 Cat } 3 \text { TQ (DOE-STD-1027) } \\
\text { (DOE 1992) }\end{array}$ & $\begin{array}{l}\text { Hazard analysis shows potential for localized } \\
\text { significant consequences }\end{array}$ \\
\hline \multicolumn{3}{|c|}{ Nonnuclear Facilities (DOE Order 5481.1B) } \\
\hline Low Hazard & $\begin{array}{l}\text { Personal injury to not more than five } \\
\text { people onsite } \\
\text { - Personnel radiation exposure does not. } \\
\text { exceed an effective dose equivalent of } \\
3 \text { rem/yr }(0.03 \mathrm{~Sv} / \mathrm{yr}) \\
\text { - No potential for nuclear criticality } \\
\text { - No offsite exposures to hazardous } \\
\text { materials in excess of the applicable } \\
\text { TLVs } \\
\text { - No increased safety risk to the offsite } \\
\text { public from hazards not routinely } \\
\text { accepted by the public } \\
\text { - No environmental impact. }\end{array}$ & $\begin{array}{l}\text { Hazard analysis shows potential for minor } \\
\text { onsite impacts and negligible offsite impacts to } \\
\text { people or the environment. }\end{array}$ \\
\hline Medium Hazard & $\begin{array}{l}\text { - Personal injury to not more than ten } \\
\text { people and/or five fatalities onsite } \\
\text { - Up to five injuries but no fatalities } \\
\text { offsite } \\
\text { - Onsite and offsite radioactive release and } \\
\text { exposure exceeding DOE Orders } \\
5480.11 \text { and } 5400.5 \text { limits } \\
\text { - Unplanned nuclear criticality } \\
\text { - Offsite exposures to hazardous materials } \\
\text { in excess of applicable TLVs } \\
\text { - Significant, but reversible environmental } \\
\text { impact. }\end{array}$ & $\begin{array}{l}\text { Hazard analysis shows considerable potential } \\
\text { for onsite impacts to people or the } \\
\text { environment, but minor offsite impacts. }\end{array}$ \\
\hline High Hazard & $\begin{array}{l}\text { Personal injury to more than ten people } \\
\text { and/or more than five fatalities onsite } \\
\text { - Up to five injuries and/or any fatalities } \\
\text { offsite } \\
\text { - Offsite exposures to radiation exceeding } \\
\text { DOE Orders } 6430.1 \mathrm{~A} \text { and } 5480.6 \text { limits } \\
\text { - Offsite exposures to hazardous materials } \\
\text { immediately dangerous to life and health } \\
\text { - Significant, irreversible environmental } \\
\text { impact. }\end{array}$ & $\begin{array}{l}\text { Hazard analysis shows considerable potential } \\
\text { for onsite or offsite impacts to large numbers } \\
\text { of people or from major impacts to the } \\
\text { environment. }\end{array}$ \\
\hline
\end{tabular}


ER activities that involve combinations of radioactive materials should be designated as Category 3 or radiological if the sum of the ratios of the quantities of each material to the Category 3 or radiological thresholds exceeds one. The sum of the ratio is given by Equation (3-1) and is described in DOE-STD-1027-92 (DOE 1992).

$$
R=\sum_{j=1}^{n} \frac{I_{j}}{I_{t_{j}}}
$$

where

$$
\begin{aligned}
& \mathrm{R}=\text { sum of the ratios } \\
& \mathrm{n}=\text { total number of isotopes (chemicals) present } \\
& \mathrm{j}=\text { contaminant counter } \\
& \mathrm{I}_{\mathrm{j}}=\text { inventory of isotope (chemical) } \mathrm{j} \\
& \mathrm{I}_{\mathrm{tj}}=\text { threshold value of isotope (chemical) } \mathrm{j} .
\end{aligned}
$$

The ratio, $\mathrm{R}$, must consistently apply the same category threshold list (that is, Category 2, Category 3, or radiological thresholds). For example, if the Category 3 threshold quantities were used to assess the hazard classification of a particular activity and the sum of the ratios, $R$, was greater than 1, and the sum of the ratios when recalculated using the Category 2 threshold quantities was less than 1, then the activity would be classified as Hazard Category 3. However, if the sum of the ratios exceeded 1 using the Category 2 threshold quantities, then the activity would be classified as Hazard Category 2 .

One criterion for nonnuclear hazard classifications is based on exposure to hazardous chemicals. DOE-ID 5481.1B gives further guidance for hazardous chemicals by comparing exposures to TLVs. This has been interpreted to mean ACGIH TLVs (ACGIH 1992) or OSHApermissible exposure limits (PELs) (NIOSH 1990). In the event of conflicting exposure limits as defined by these agencies, the more stringent limit is used for compliance. The exposure limits are based on exposure to one chemical only. In most cases, there is no information on the synergistic effects of exposures to multiple chemicals at once; however, ACGIH (ACGIH 1992) suggests using Equation (3-1) to assess whether exposure to multiple chemicals is likely to lead to injury. When the sum of the ratios, $R$, is less than 1 , then the potential exposure from the mixture is also below the limit. Classifications based on TLV limits will be determined after the accident scenarios have been evaluated because TLVs and PELs are given as exposure concentrations $\left(\mathrm{mg} / \mathrm{m}^{3}\right.$ ) and are compared to worker or public exposure concentrations caused by the activity.

ER activities may be subdivided into segments provided passive features preclude bringing material together or causing harmful interaction from a common event or severe phenomenon. The overall hazard classification of an ER activity is the highest hazard category classification of 
the various segments of the activity. An activity, structure, or facility segment is assigned a hazard category according to the material inventory associated with that segment. However, by segmenting the activity, the necessary and appropriate design and administrative controls will be provided commensurate with the hazard.

As an example, ER activities such as excavations normally do not expose the entire inventory of radioactive or hazardous material in the ground for release. Typically, only the top surface of the excavation area is available for a release that may affect workers or the public. Therefore, the inventory of radioactive or hazardous material available for release by postulated events (such as high wind or fire) for the purpose of hazard classification, can be segmented to include only the surface quantity to a justifiable depth.

Similarly, an activity may be segmented based on physical separation. For example, a facility undergoing D\&D may be segmented if facets of the facility are physically separated so that materials cannot be brought together to total more than the radioactive or hazardous material threshold limits.

Documentation of the classification in the activity-specific safety documentation can be as simple as providing two tables, one for the radiological inventory and one for the hazardous material inventory. These tables should identify the contaminant, the quantity, the classification limit (TQ, TPQ, RQ), and the ratio. To demonstrate this process, Tables 3-5 and 3-6 are provided as an example for radionuclide and hazardous chemical inventories respectively. The inventory, listed in Column 2, is based on a concentration of contaminants in 100,000 kilograms of soil. The classification limits are expressed as curies for radionuclides and kilograms for chemicals. Therefore, the inventory is converted by multiplying by the amount of soil available for release $(100,000 \mathrm{~kg})$ and applying the necessary conversion factors. The result is presented in Column 3.

For radionuclides, the Category $3 \mathrm{TQ}$ limit and the calculated ratio are identified in Columns 4 and 6 of Table 3-5, respectively. All TQ ratios are less than 1 (including the total); therefore, an activity with these type of contaminants and concentrations would not be classified as a Category 3 hazard. The RQ limit and calculated RQ ratio are presented in Columns 5 and 7, respectively. If the individual $R Q$ ratios are less than 1 , however, the total $R Q$ ratio is greater than 1. Therefore, the activity would be classified as a radiological hazard and an ASA would be the required safety documentation.

The hazardous chemical inventory (presented in Table 3-6) is then compared to the TQ, TPQ, and RQ to ensure that an ASA is appropriate. None of the chemicals have TQs associated with them. Cresol and Phenol have TPQ limits as indicated in Column 5. The RQ limits are presented in Column 4. The chemical inventories are all below the RQ limits. Therefore, an ASA is the appropriate safety docurnentation. However, if the inventories exceeded the TPQs, a safety analysis written to the requirements of DOE Order 5481.1B would be required. 
Table 3-5. Example radioactive material hazard classification.

\begin{tabular}{|c|c|c|c|c|c|c|}
\hline Radionuclide & $\begin{array}{l}\text { Inventory } \\
(\mathrm{pCi} / \mathrm{g})\end{array}$ & $\begin{array}{l}\text { Inventory } \\
\text { (Ci) }\end{array}$ & $\begin{array}{c}\text { Category } 3 \mathrm{TQ} \\
\text { (Ci) }\end{array}$ & $\begin{array}{l}R Q \\
(\mathrm{Ci})\end{array}$ & TQ ratio & RQ ratio \\
\hline${ }^{241} \mathrm{Am}$ & $1.1 E+01$ & 1.1E-03 & $5.2 \mathrm{E}-01$ & $1.0 \mathrm{E}-02$ & $2.1 \mathrm{E}-03$ & 1.1E-01 \\
\hline${ }^{60} \mathrm{Co}$ & $1.3 \mathrm{E}+03$ & $1.3 \mathrm{E}-01$ & $2.8 \mathrm{E}+02$ & $1.0 \mathrm{E}+01$ & 4.6E-04 & $1.3 \mathrm{E}-02$ \\
\hline${ }^{51} \mathrm{Cr}$ & $7.3 \mathrm{E}+00$ & 7.3E-04 & $2.2 \mathrm{E}+04$ & $1.0 \mathrm{E}+03$ & 3.3E-08 & 7.3E-07 \\
\hline${ }^{134} \mathrm{Cs}$ & $3.0 \mathrm{E}+01$ & $3.0 \mathrm{E}-03$ & $4.2 \mathrm{E}+01$ & $1.0 \mathrm{E}+00$ & $7.1 \mathrm{E}-05$ & $3.0 \mathrm{E}-03$ \\
\hline${ }^{137} \mathrm{Cs}$ & $9.2 E+03$ & 9.2E-01 & $6.0 \mathrm{E}+01$ & $1.0 \mathrm{E}+00$ & $1.5 \mathrm{E}-02$ & $9.2 \mathrm{E}-01$ \\
\hline${ }^{152} \mathrm{Eu}$ & $2.0 \mathrm{E}+01$ & $2.0 \mathrm{E}-03$ & $2,0 \mathrm{E}+02$ & $1.0 \mathrm{E}+01$ & 1.0E-05 & $2.0 \mathrm{E}-04$ \\
\hline${ }^{154} \mathrm{Eu}$ & $1.4 \mathrm{E}+01$ & $1.4 \mathrm{E}-03$ & $2.0 \mathrm{E}+02$ & $1.0 \mathrm{E}+01$ & $7.0 \mathrm{E}-06$ & $1.4 \mathrm{E}-04$ \\
\hline${ }^{239 / 240} \mathrm{Pu}$ & $9.1 E+00$ & 9.1E-04 & 5.2E-01 & $1.0 \mathrm{E}-02$ & $1.8 \mathrm{E}-03$ & 9.1E-02 \\
\hline${ }^{238} \mathrm{Pu}$ & $1.9 E+00$ & 1.9E-04 & $6.2 \mathrm{E}-01$ & $1.0 \mathrm{E}-02$ & $3.1 \mathrm{E}-04$ & $1.9 \mathrm{E}-02$ \\
\hline${ }^{90} \mathrm{Sr}$ & $4.2 \mathrm{E}+02$ & 4.2E-02 & $1.6 E+01$ & $1.0 \mathrm{E}-01$ & $2.6 \mathrm{E}-03$ & 4.2E-01 \\
\hline${ }^{234} \mathrm{U}$ & $5.1 E+00$ & 5.1E-04 & $4.2 \mathrm{E}+00$ & $1.0 \mathrm{E}-01$ & $1.2 \mathrm{E}-04$ & 5.1E-03 \\
\hline${ }^{235} \mathrm{U}$ & $2.0 \mathrm{E}+01$ & 2.0E-03 & $4.2 \mathrm{E}+00$ & $1.0 \mathrm{E}-01$ & $4.8 \mathrm{E}-04$ & 2.0E-02 \\
\hline${ }^{238} \mathrm{U}$ & $1.9 \mathrm{E}+00$ & $1.9 \mathrm{E}-04$ & $4.2 \mathrm{E}+00$ & $1.0 \mathrm{E}-01$ & $4.5 \mathrm{E}-05$ & 1.9E-03 \\
\hline${ }^{65} \mathrm{Zn}$ & $2.9 \mathrm{E}+00$ & 2.9E-04 & $2.4 \mathrm{E}+02$ & $1.0 \mathrm{E}+01$ & $1.2 \mathrm{E}-06$ & 2.9E-05 \\
\hline${ }^{95} \mathrm{Zr}$ & $3.1 E+00$ & 3.1E-04 & $7.0 \mathrm{E}+02$ & $1.0 \mathrm{E}+01$ & 4.4E-07 & 3.1E-05 \\
\hline \multicolumn{5}{|c|}{ Ratio } & $2.3 \mathrm{E}-02$ & $1.6 \mathrm{E}+00$ \\
\hline
\end{tabular}

Table 3-6. Example hazardous material hazard classification.

\begin{tabular}{lcccc}
\hline Chemical & $\begin{array}{c}\text { Soil concentration } \\
(\mathrm{mg} / \mathrm{kg})\end{array}$ & $\begin{array}{c}\text { Inventory } \\
(\mathrm{kg})\end{array}$ & $\begin{array}{c}\mathrm{RQ} \\
(\mathrm{kg})\end{array}$ & $\begin{array}{c}\text { TPQ } \\
(\mathrm{kg})\end{array}$ \\
\hline Cresol & $2.2 \mathrm{E}+02$ & 106.9 & 454 & 4,540 \\
Phenol & $2.4 \mathrm{E}+00$ & 1.1 & 454 & 227 \\
Toluene & $4.0 \mathrm{E}-03$ & $19.4 \mathrm{E}-4$ & 454 & NA \\
\hline
\end{tabular}

3.3.2.3 Hazard Evaluation. This section of the activity-specific safety document should describe and evaluate the hazards identified in Section 3.3.2.1. The outcome of the evaluation is to identify hazards that may result in accident scenarios that could cause worker or public exposure to radionuclides and hazardous materials above guidance levels. These accident scenarios are then analyzed in Section 3.4.

The rigor associated with the hazard evaluation is based on the types of hazards present and the complexity of the operation. In a complex operation, potential accident scenarios may need 
to be identified using detailed analyses such as failure modes and effects analysis, a hazard and operability study, or probabilistic risk assessment techniques using fault trees and event trees. Less complex operations can be analyzed using analyses such as the What-if process or a process hazards analysis. Most ER activities do not involve a lot of technical equipment and detailed processes. Therefore, a recommended method for performing and documenting the hazard evaluation is providing information for each hazard as illustrated in Table 3-7. The column headings in Table 3-7 are defined as follows:

- Hazard-lists potential hazards identified in Section 3.3.2.1, such as radioactive material

- Possible causes-possible causes of the hazard are described

- Potential impacts-describes potential effects of the hazard on workers, the public, or the environment. For example, workers may be subjected to radiation exposure as part of normal activities; or, postulated events including equipment failure or human error may result in unplanned release of radioactive material

- Preventive or mitigative features-identifies and describes design and/or administrative controls provided to prevent or mitigate the hazard, such as HEPA filter systems, emergency plans, etc.

- Method of detection-identifies and describes the means of detecting the hazard, such as area radiation monitors or routine surveillance.

Table 3-7. Example hazard assessment table.

\begin{tabular}{|c|c|c|c|c|c|}
\hline \multirow[b]{2}{*}{ Hazard } & \multirow[b]{2}{*}{ Possible causes } & \multirow[b]{2}{*}{ Potential impacts } & \multicolumn{2}{|c|}{ Preventive or mitigative features } & \multirow{2}{*}{$\begin{array}{l}\text { Method of } \\
\text { detection }\end{array}$} \\
\hline & & & Design & Administrative & \\
\hline $\begin{array}{l}\text { Flammable vapors } \\
\text { and/or liquid present } \\
\text { in the tank ignites } \\
\text { during cutting } \\
\text { operations }\end{array}$ & $\begin{array}{l}\text { Workers fail to } \\
\text { comply with } \\
\text { procedures, or } \\
\text { procedures fail to } \\
\text { require checking } \\
\text { and monitoring } \\
\text { for flammable } \\
\text { vapors and/or } \\
\text { liquids }\end{array}$ & $\begin{array}{l}\text { Worker exposure to } \\
\text { radioactive or } \\
\text { hazardous material } \\
\text { above anticipated } \\
\text { for normal } \\
\text { operations }\end{array}$ & None & Use of PPE & Monitoring \\
\hline $\begin{array}{l}\text { Tank is dropped and } \\
\text { splits open while being } \\
\text { lifted out of the hole }\end{array}$ & $\begin{array}{l}\text { Failure to } \\
\text { properly secure } \\
\text { tank before } \\
\text { lifting, lifting } \\
\text { equipment fail } \\
\text { during lift }\end{array}$ & $\begin{array}{l}\text { Worker exposure to } \\
\text { radioactive or } \\
\text { hazardous material } \\
\text { above anticipated } \\
\text { for normal } \\
\text { operations }\end{array}$ & $\begin{array}{l}\text { Equipment } \\
\text { is rated for } \\
\text { the lift }\end{array}$ & $\begin{array}{l}\text { Equipment is } \\
\text { checked before } \\
\text { lift, use of PPE } \\
\text { during operations }\end{array}$ & $\begin{array}{l}\text { Visual, } \\
\text { monitoring }\end{array}$ \\
\hline $\begin{array}{l}\text { Natural phenomena } \\
\text { (seismic, high wind) } \\
\text { expose contents of } \\
\text { tank }\end{array}$ & $\begin{array}{l}\text { Natural } \\
\text { phenomena }\end{array}$ & $\begin{array}{l}\text { Worker exposure to } \\
\text { radioactive or } \\
\text { hazardous material }\end{array}$ & None & $\begin{array}{l}\text { Operations will not } \\
\text { be allowed during } \\
\text { high winds, use of } \\
\text { PPE }\end{array}$ & $\begin{array}{l}\text { Visual, } \\
\text { monitoring }\end{array}$ \\
\hline
\end{tabular}


The hazard evaluation should be performed by experienced safety analysts assisted by ER project staff knowledgeable about the planned activity. Walk-down of the activity/area by the appropriate personnel should be considered. The hazard evaluation should include use of the hazard checklists and DOE experience databases to ensure that the results are comprehensive. The following special guidelines are provided for hazard evaluation of occupational, fire, and natural phenomena hazards:

- Occupational hazards, including standard industrial hazards, that are regulated by OSH standards require no additional hazard evaluation in this section. These hazards should be identified in Table 3-1 of Section 3.3.2.1 along with the applicable OSH standards and any analyses that have been written to satisfy the OSH standards should be referenced.

- Fire hazards and effects on personnel safety are considered standard industrial hazards and require no specific hazard analysis unless the fire has a potential to release radioactive or hazardous material. It should then be identified in this section and analyzed in Section 3.4. Fire is an expected hazard for ER activities. However, damage to ER facilities is not a major concern, other than potential releases, because it is not considered a loss if the facility is destroyed by fire. Any documented fire hazard analyses prepared for the activity or facility according to required standards (such as DOE Order 5480.7A) and any applicable OSHA standards should be réferenced.

- Natural phenomena hazards such as earthquakes, floods, and high winds that could affect ER activities should be summarized in Chapter 1. Those that contribute to, or initiate a release of, radioactive or hazardous material during ER activities should be identified in this section and analyzed in Section 3.4. Typically, activities covered by the BSAF are of short duration and are not complex, resulting in minimal risk from natural phenomena.

3.3.2.3.1 Planned Design and Operational Safety Improvements-Any planned improvements not yet implemented but recommended based on the results of the hazard evaluation should be addressed in this subsection. Generally for ER activities, this subsection will not be applicable.

3.3.2.3.2 Defense in Depth-This section does not apply to activities classified as radiological, as explained in Chapter 5. However, it does apply to activities classified as Hazard Category 3 that require TSRs and can be used to supplement low hazard activities requiring operational safety requirements (OSRs). This subsection of the activity-specific safety document should summarize significant aspects of defense in depth, and identify associated safety-significant structures, systems, or components (SSCs) and other items needing technical safety requirement (TSR) coverage. This includes both the facility design (if any exists) and administrative controls and procedures that have been implemented to prevent releases.

This section should address each barrier that is in place to prevent a release of radioactive or hazardous materials to the environment. Barriers not only include structural fixtures such as a building, HEPA filter system, or temporary confinements constructed specifically for the activity, but may also include activity-specific procedures, personnel protective equipment, and other 
administrative guidelines that are established to prevent environmental or worker exposure to radionuclides and/or hazardous chemicals. This is demonstrated in Appendix 3A (at the end of this chapter).

3.3.2.3.3 Worker Safety-This subsection of the activity-specific safety document should summarize the major features such as SSCs and administrative controls that are in place to protect the workers from the identified hazards, exclusive of standard industrial hazards. The Health and Safety Plan identifies necessary personal protective equipment to be used during the activity and should be referenced in this section. The conclusion of this subsection should be that the specified personal protective equipment provides adequate protection to the worker for the identified hazards.

3.3.2.3.4 Environmental Protection-This subsection of the activity-specific safety document should summarize the design and operational features that reduce the potential for large radioactive and hazardous material releases to the environment. This subsection should conclude that no large release with the potential to cause significant environmental insult exists that an obvious and easily implemented design or operational change not could minimize. In the majority of instances, process-related TSRs and safety SSCs assigned for defense in depth will be sufficient to address environmental concerns. The net environmental impact from ER activities should be completely beneficial beciause the result will be removal/reduction/stabilization of pollutants already in the environment.

3.3.2.3.5 Accident Selection-A primary objective of the safety analysis is to identify and assess risks of the ER activity caused by equipment failure, human error, natural phenomena, or a combination of these factors. Risk, as defined by DOE Order 5480.23 , is "the quantitative or qualitative expression of possible loss that considers both the probability that an event will occur and the consequence of that event." Most ER activities will not need a detailed analysis with probabilities and consequences. DOE-STD-3009-94 (DOE 1994b) states that the hazard analysis activity is considered sufficient for Hazard Category 3 activities and that detailed accident quantification is not necessary because potential consequences are well below Evaluation Guidelines. However, to ensure that the activity will not exceed the Evaluation Guidelines, the bounding accidents should be analyzed. The bounding accidents address those hazards that would expose the worker to the greatest concentration of radionuclides, or hazardous chemicals, or high radiation fields. These acciclents will be further analyzed in Section 3.4. For more complex activities that need greater analysis, the analyst should follow the guidance given in DOE-STD-3009-94 (DOE 1994b) for accident selection using a hazard matrix.

\subsection{Accident Analysis}

This section of the activity-specific safety document should present the formal development of the bounding accidents identified in Section 3.3.2.3.5 that need further analysis. Hazard Category 3 and low hazard activities have the potential for only localized significant consequences, and the analysis should focus on significant risks to the worker. The outcome of the accident analysis is used to identify any safety-significant SSCs, TSRs, OSRs and safety equipment needed to protect the operators. The format suggested in DOE-STD-3009-94 (DOE 1994b) is not completely followed for this section because most ER activities will not analyze for design basis 
accidents but for the bounding accident scenarios. The analyst should follow the guidance given in DOE-STD-3009-94 (DOE 1994b) if the activity requires design basis analyses. The basic format is identified in the following sections.

\subsubsection{Methodology}

This section of the activity-specific safety document should summarize the methods used to quantify the consequences of the bounding accidents selected in Section 3.3.2.3.5. The methodologies presented in the following subsections can be used in the activity-specific safety document to perform the hazards analyses. Other methodologies can be used but will need to be described in this section of the activity-specific safety document.

The Radiological Safety Analysis Computer program (RSAC) (Wenzel 1993) is recommended for airborne dispersion of radioactive and nonradioactive hazardous materials (depending on the form) modelling because it was developed specifically for releases over desert terrains, such as the INEL, and has been subjected to extensive validation and verification. However, certain situations may require the use of other computer codes or methodologies. Alternate codes and methodologies, accompanied by justification for selection, should be used as appropriate. Various consequence analysis computer codes (including RSAC), code application, general functional description, and basic features are listed in Table 3-8.

3.4.1.1 Radjological Consequence Analysis. Radiological consequences to downwind receptors should be estimated using RSAC. However, RSAC is limited to determining dispersion at distances of $100 \mathrm{~m}$ or greater. Therefore, worker exposures $(<100 \mathrm{~m})$ are calculated by hand.

3.4.1.1.1 Receptors Within $100 \mathrm{~m}$-The inhalation exposure estimates for receptors within $100 \mathrm{~m}$ (workers) can be calculated using Equation (3-2). Inhalation exposure is usually the most limiting pathway and is, therefore, the only pathway analyzed.

$\mathrm{WECED}=\mathrm{RC} \times \mathrm{BR} \times \mathrm{ED} \times \mathrm{DCF}$

where

$\begin{array}{ll}\text { WECED } & =\text { worker exposure committed effective dose equivalent (CEDE) } \\ \mathrm{RC} & =\text { radionuclide concentration in the air inhaled by the worker } \mathrm{Ci} / \mathrm{m}^{3} \\ \mathrm{BR} & =\text { breathing rate } 3.33 E-04 \mathrm{~m}^{3} / \mathrm{s} \\ \mathrm{ED} & =\text { exposure duration }(\mathrm{s}) \\ \mathrm{DCF} & =\text { dose conversion factor }(\mathrm{rem} / \mathrm{Ci}) .\end{array}$


Table 3-8. Examples of consequence analysis computer codes.

\begin{tabular}{|c|c|c|c|}
\hline Code & Application & Description & Features \\
\hline $\begin{array}{l}\text { RSAC } \\
\text { Radiological Safety } \\
\text { Analysis Computer } \\
\text { Program (Wenzel 1993) }\end{array}$ & $\begin{array}{l}\text { Radiological } \\
\text { dose assessment }\end{array}$ & $\begin{array}{l}\text { Calculates radiological doses to } \\
\text { workers/public by inhalation, } \\
\text { ingestion, and external exposure } \\
\text { pathways resulting from acute or } \\
\text { chronic airborne releases of } \\
\text { radioactive materials. Atmospheric } \\
\text { dispersion factors calculated by } \\
\text { RSAC can be used for modeling } \\
\text { releases of nonradiological } \\
\text { materials. }\end{array}$ & $\begin{array}{l}\text { Developed specifically for } \\
\text { INEL; incorporates site-specific } \\
\text { meteorological conditions such } \\
\text { as desert dispersion; can } \\
\text { incorporate time-dependent } \\
\text { releases. }\end{array}$ \\
\hline $\begin{array}{l}\text { GENII } \\
\text { GENII - The Hanford } \\
\text { Environmental } \\
\text { Radiation Dosimetry } \\
\text { Software System (Napier } \\
\text { 1988) }\end{array}$ & $\begin{array}{l}\text { Radiological } \\
\text { impact } \\
\text { assessment }\end{array}$ & $\begin{array}{l}\text { Analyzes environmental } \\
\text { contamination resulting from } \\
\text { chronic or acute releases of } \\
\text { radionuclides to/from initial } \\
\text { concentration of radionuclides in } \\
\text { air, water, soil; calculates radiation } \\
\text { doses to individuals/populations. }\end{array}$ & $\begin{array}{l}\text { Documentation available; } \\
\text { relatively easy to use; widely } \\
\text { known; does not require } \\
\text { another code to complete } \\
\text { radiological assessment. }\end{array}$ \\
\hline $\begin{array}{l}\text { SLAB } \\
\text { A Denser-Than-Air } \\
\text { Atmospheric Dispersion } \\
\text { Model (Ermac 1989) }\end{array}$ & $\begin{array}{l}\text { Environmental } \\
\text { transport and } \\
\text { diffusion } \\
\text { evaluation }\end{array}$ & $\begin{array}{l}\text { Simulates atmospheric dispersion } \\
\text { of denser-than-air vapor release; } \\
\text { subsequent dispersion is modeled } \\
\text { as steady state plume, transient } \\
\text { puff, or combination. }\end{array}$ & $\begin{array}{l}\text { Simulates instantaneous and } \\
\text { time variable releases, } \\
\text { dispersion, entrainment; good } \\
\text { performance in validation and } \\
\text { verification comparisons. }\end{array}$ \\
\hline $\begin{array}{l}\text { ARCHIE } \\
\text { Automated Resource } \\
\text { for Chemical Hazard } \\
\text { Incident Evaluation } \\
\text { (FEMA 1989) }\end{array}$ & $\begin{array}{l}\text { Consequence } \\
\text { assessment of } \\
\text { radioactive/ } \\
\text { hazardous } \\
\text { material releases } \\
\text { for tanks or } \\
\text { pipelines. }\end{array}$ & $\begin{array}{l}\text { Estimates gas or liquid discharge } \\
\text { rate and duration; size of liquid } \\
\text { pool; rate at which pool evaporates } \\
\text { or boils; downwind hazards; } \\
\text { consequences of explosion. }\end{array}$ & Easy to use. \\
\hline
\end{tabular}

The curie (Ci) content for each radionuclide is specific to each accident scenario and is the same as that used in calculations for downwind receptors. The radionuclide concentration (RC) in the air inhaled by the worker is dependent on the plume volume assumed to surround the worker or a room/building volume, and the airborne release fraction (ARF), the respirable fraction (RF), and the damage ratio (DR). A more detailed description of these fractional parameters is presented in Section 3.4.1.1.2 for receptors at greater than $100 \mathrm{~m}$. The breathing rate is assumed to be $3.33 \mathrm{E}-04 \mathrm{~m}^{3} / \mathrm{second}$ based on the assumption the worker inhales $2,400 \mathrm{~m}^{3}$ of air during a 2,000-hr work year (ICRP 1975 and DOE Order 5480.11). The exposure duration is dependent on the specific conditions (typically no more than a 120-second time period is assumed for the workers in the immediate area as evacuation is expected). The DCFs are obtained from DOE/EH-0071 (DOE 1988a) and the ARFs and RFs from DOE-HDBK-3010-94 (DOE 1994c).

Direct exposure estimates are determined from the exposure time of the individual worker. 
3.4.1.1.2 Receptors at Greater Than $100 \mathrm{~m}$-Exposure calculations for receptors at greater than $100 \mathrm{~m}$ typically are performed by codes such as those listed in Table 3-8. RSAC is used in the following discussion for illustrative purposes. Model and input requirements specific to RSAC are found in the RSAC Manual (Wenzel 1993).

To calculate downwind radiological consequences from RSAC, an accident source term (AST) must be calculated. An AST is the amount of radioactive material released from an event or facility during a specific accident scenario. ASTs are determined using the following equation:

$\mathrm{AST}=\mathrm{MAR} \times \mathrm{CF} \times \mathrm{DR} \times \mathrm{RF} \times \mathrm{ARF}$

where
AST $=$ accident source term (Ci)
MAR = material at risk $\left(\mathrm{m}^{3}\right)$
$\mathrm{CF}=$ concentration factor $\left(\mathrm{Ci} / \mathrm{m}^{3}\right)$
DR = damage ratio
RF $\quad=$ respirable fraction
$\mathrm{ARF}=$ airborne release fraction.

Note: Other methods may be used to calculate the source term. The source term calculations will depend on factors such as activity, media, and location.

The AST is the total amount of dispersible radioactive material released. The AST is multiplied by the individual fraction of each radionuclide to determine the Ci content input for RSAC. For example, if the AST $=1.0 \mathrm{Ci}$, and the radionuclide fractionation is

$\begin{array}{ll}\frac{\text { Radionuclide }}{{ }^{60} \mathrm{Co}} & \frac{\text { Fraction }}{0.50} \\ { }^{137} \mathrm{Cs} & 0.25 \text { (include contribution of }{ }^{137 \mathrm{~m}} \mathrm{Ba} \text { ) } \\ { }^{90} \mathrm{Sr} & 0.25\end{array}$

then the inventory per individual radionuclide is

\begin{tabular}{|c|c|}
\hline Radionuclide & $\underline{\text { Ci Content }}$ \\
\hline${ }^{60} \mathrm{Co}$ & $5.00 \mathrm{E}-01$ \\
\hline${ }^{137} \mathrm{Cs}$ & $2.50 \mathrm{E}-01$ \\
\hline${ }^{137} \mathrm{~m} \mathrm{Ba}$ & 2.37E-01 \\
\hline${ }^{90} \mathrm{Sr}$ & $2.50 \mathrm{E}-01$ \\
\hline
\end{tabular}


This inventory is input into RSAC. The variables are further defined as follows:

- Material at Risk. The MAAR is the total inventory of material (such as soil or sludge) available to be impacted for a given accident scenario and is typically expressed in terms of total volume at risk in cubic meters. The MARs for each activity or area that contains radioactive or hazardous materials are provided in the scenario development subsection for each analyzed accident.

- Concentration Factor. The $\mathrm{CF}$ is the concentration of the radioactive or hazardous material at a given area or activity. The $C F$ is used to convert from a volume (MAR) measurement to a total $\mathrm{Ci}$ content of the material (such as soil or sludge) for a particular area or activity. The $\mathrm{CF}$ is expressed in terms of $\mathrm{Ci}$ per cubic meter. Concentrations are provided in the source term subsection for each analyzed accident.

- Damage Ratio. The DR represents the percentage of MAR available for exposure to onsite and offsite receptors from the postulated scenario. The DR includes the leak path factor which accounts for reduction in the MAR caused by the containment inhibiting the total release of the source term. This percentage does not take into account RF or ARF of the MAR.

- Respirable Fraction. The RF of the released material is that fraction of the MAR with an aerodynamic equivalent diameter less than 3.94E-04 in. (10 $\mu \mathrm{m})$ and a mass associated with airborne particles. Most scenarios will use an RF of 1.0. An exception is fire. Fire scenarios must estimate a percentage of combustible and noncombustible material. The RF for combustible material is 1.0 and $1 \mathrm{E}-03$ for noncombustible material (DOE 1994c).

- Airborne Release Fraction. The ARF is that fraction of the total radioactive material assumed released in a dispersible form by a postulated accident. The following recommended ARFs are taken from DOE-HDBK-3010-94 (DOE 1994c):

Combustible Solids

Fires $5.0 \mathrm{E}-04$

Explosions $1.0 \mathrm{E}-03$

Spills, breaches, crush impacts, etc.

$1.0 \mathrm{E}-03$

Noncombustible Solids

Fires

Explosions

$5.0 \mathrm{E}-03$

Spills, breaches, crush impacts, etc.

$1.0 \mathrm{E}-03$

\section{Liquids}

Free-fall spill (aqueous solution)

$2.0 \mathrm{E}-04$

Free-fall spill (transuranic solutions)

$2.0 \mathrm{E}-05$

Note: The liquid ARFs are for aqueous solutions with density near $1 \mathrm{~g} / \mathrm{cc}$ and for transuranic solutions with density greater than $1 \mathrm{~g} / \mathrm{cc}$. For other specific ARFs for 
aqueous solutions and/or other types of liquids, refer to DOE-HDBK-3010-94 (DOE 1994c).

The various assumptions and parameters input into RSAC are discussed in the RSAC Users Manual (Wenzel 1993). Additional information on the bases for the RSAC assumptions, particularly for ingestion and inhalation doses, can be found in the recommendations of the International Commission of Radiological Protection (ICRP 1977).

3.4.1.2 Hazardous Chemicals Consequence Analysis. This section presents some recommended methods for determining consequences of a release of hazardous chemicals.

Computer codes, if available, should be used, such as those listed in Table 3-8. Other available computer codes may be used if applicable to the situation being evaluated.

Air concentrations are estimated at the location of workers (within $100 \mathrm{~m}$ of the release), the collocated worker $(100 \mathrm{~m})$, and if necessary, the offsite public at the nearest public highway or site boundary. All chemical concentrations should be reported in units of $\mathrm{mg} / \mathrm{m}^{3}$. For asbestos, concentrations are measured in fibers $/ \mathrm{cm}^{3}$.

The consequences may be calculated manually using Equation (3-4) for onsite workers and Equation (3-5) for downwind receptors.

$$
\begin{aligned}
& \left(\mathrm{mg} / \mathrm{m}^{3}\right)=(\mathrm{Q} \times \mathrm{T}) /(\mathrm{RD} \times \mathrm{V}) \\
& \left(\mathrm{mg} / \mathrm{m}^{3}\right)=(\mathrm{Q} \times \mathrm{DC}) / \mathrm{RD}
\end{aligned}
$$

where

$$
\begin{aligned}
& \mathrm{Q}=\text { quantity of hazardous material released (milligrams or fibers) } \\
& \mathrm{T}=\text { worker exposure time (seconds) } \\
& \mathrm{RD}=\text { release duration (seconds) } \\
& \mathrm{V}=\text { plume volume }\left(\mathrm{m}^{3}\right) \\
& \mathrm{DC}=\text { dispersion coefficient }(\chi / \mathrm{Q}) \text { for specific downwind receptor. }
\end{aligned}
$$

For outside conditions, the worker exposure time, $\mathrm{T}$, is equal to, or less than, the release duration; the contamination is dispersed into an infinite plume, and workers can move upwind or away from the plume.

Comparison of exposure concentration to a threshold limit value-time weighted average (TLV-TWA) is made by multiplying the exposure concentration by the worker's exposure time 
divided by $8 \mathrm{hr}(\mathrm{T} / 8 \mathrm{hr})$. The TLV-TWA is a time-weighted average concentration for a normal 8-hr work day. When comparing the exposure concentration to a TLV-short-term exposure limit (TLV-STEL), the concentration is multiplied by T/15 min. The TLV-STEL is a maximum average concentration for a 15 -min continuous exposure period. When an exposure concentration is compared to the immediately dangerous to life and health (IDLH) limit, no fractional time exposure reduction is applied. The IDLH represents a maximum concentration from which one could escape within 30 min without impairing symptoms or any irreversible health effects.

RSAC is recommended for use in determining the dispersion coefficient $(\chi / Q)$. Parameters in Equations (3-4) and (3-5) are based on the same assumptions used for radiological consequences.

The effect of exposure to multiple toxicological substances is assumed to be additive if the biological response is the same and chemicals are not concentration dependent. The concentration of the hazardous constituent at the receptor location is divided by the Emergency Response Planning Guideline (ERPG), as appropriate for that receptor, which yields the fraction of the ERPG. Summing these fractions provides a means of evaluating the additive effects. If the sum of the fractions for a given receptor is less than 1, the combined release is assumed to pose no health hazard to that receptor.

\subsubsection{Bounding Accidents}

This section of the activity-specific safety document should address each accident scenario identified in Section 3.3.2.3.5 that requires further analysis. Each accident will be analyzed individually and will include the following subsections: scenario development, source term analysis, consequence analysis, comparison to guidelines, and summary of safety-class SSCs and TSR control. Each scenario is based on release of radioactive or hazardous materials.

3.4.2.X Applicable Bounding Accident. The following subsections are repeated sequentially for each ("X") bounding accident.

3.4.2.X.1 Scenario Development-This section should provide a complete description of the postulated accident scenario. An accident sequence identification should be included in this description. An accident sequence is the chain of events that begins with an initiating event and includes subsequent events that result in accident consequences. Part of the analysis includes estimating accident frequency. The objective of accident sequence selection is to choose unique accident sequences that could have a major effect and encompass the principal release mechanisms. Selection of accident sequences facilitates reduction of identified release mechanism information to a more manageable form.

The primary objective of the accident sequence selection step is to ensure, to the extent possible, that sequences relevant and important to safety are selected. Descriptions of the accident sequences must be technically accurate, complete, and comprehensible to an audience including analysts, anticipated reviewers, and users of the safety analysis document.

Accident sequences selected for analysis could be presented in table form and annotated to indicate potential initiators, release mechanisms, potential mitigators, and type of consequence 
(radiological, other hazard, or a combination of hazards). An example accident sequence is shown in Table 3-9. Analysis of a similar sequence is presented in Appendix 3A.

3.4.2.X.2 Source Term Analysis-This subsection of the activity-specific safety document should address the material and energy released during the accident through the pathways of concern. All parameters and phenomenological models used to derive the source term should be defined. As a minimum, this definition should include the material at risk (as derived from the hazard identification), the release fraction or rate that determines the initial source term, and the overall facility leakpath factors that determine the final source term released external to the facility (if a facility exists).

3.4.2.X.3 Consequence Analysis-This subsection of the activity-specific safety document should calculate the receptor (ER worker, collocated worker at nearby INEL facilities, public located outside the INEL site boundary, or environment) doses/exposures associated with the relevant pathways. The doses/exposures are calculated according to the methodology identified in Section 3.4.1.

3.4.2.X.4 Comparison to Guidelines-This subsection of the activity-specific safety document should compare the receptor dose/exposure for the accident sequence to the evaluation guidelines established in DOE-STD-1027-92 and DOE-EM-STD-5502-94. If evaluation guidelines cannot be met, a summary assessment should be provided of the significance of the failure to meet evaluation guidelines and administrative and/or engineered controls whose implementation would allow guidelines to be met.

3.4.2.X.5 Summary of Safety-Class SSCs and TSR Controls-This subsection of the activity-specific safety document should identify the safety-significant SSCs and assumptions judged to require TSR or OSR coverage to meet evaluation guidelines. As discussed previously, SSCs and TSRs or OSRs are not required for activities classified as radiological.

\subsection{Example Accident Analysis}

An example analysis is presented in Appendix 3A of this chapter to illustrate how the accident and hazard analyses should be performed. The example involves a tank containing radioactive and hazardous chemical materials where a potential inadvertent fire is postulated.

Table 3-9. Example accident sequence.

\begin{tabular}{ll}
\hline \multicolumn{1}{c}{ Accident sequence listing } & \multicolumn{1}{c}{ Annotation } \\
\hline Ignition source & Initiator \\
Fire & Release mechanism \\
Fire extinguisher & Possible mitigator \\
Radiological/chemical exposure & Consequence \\
Inhalation, ingestion, or dermal exposure to toxic, & Consequence \\
radioactive, or carcinogenic materials & \\
\hline
\end{tabular}




\subsection{References}

American Conference of Governmental Industrial Hygienists (ACGIH 1992), 1992-1993 Threshold Limit Values for Chemical Substances and Physical Agents and Biological Exposure Indices, ACGIH, Cincinnati, Ohio.

American Society of Mechanical Engineers (ASME, most recent), Boiler and Unfired Pressure Vessel Code, ASME.

Department of Energy (DOE 1994a), Hazard Baseline, Documentation, DOE Office of Environmental Management (EM), Washington, DC, DOE-EM-STD-5502-94.

Department of Energy (DOE 1994b), Preparation Guide for U.S. Department of Energy Nonreactor Nuclear Facility Safety Analysis Reports, Washington, DC, DOE-STD-3009-94, July 1994.

Department of Energy (DOE 1994c), Airborne Release Fractions/Rates and Respirable Fractions for Nonreactor Nuclear Facilities, Washington, DC, DOE-HDBK-3010-94, Vol 1, December 1994.

Department of Energy (DOE 1993), Hoisting and Rigging Manual, DOE, Washington, DC, DOE 10500.

Department of Energy (DOE 1992), Hazard Characterization and Accident Analysis Techniques for Compliance with DOE Order 5480.23, Nuclear Safety Analysis Reports, DOE, Washington, DC, DOE-STD-1027-92.

Department of Energy (DOE 1991), DOE Explosive Safety Manual, DOE, Washington, DC, DOE/EV/06194.

Department of Energy, Idaho Operations Office (DOE-ID 1991a), Occurrence Reporting and Processing System (ORPS), DOE-ID, Idaho Falls, ID, DOE-ID 10319.

Department of Energy, Idaho Operations Office (DOE-ID 1991b), Safety Analysis and Review System, DOE-ID, Idaho Falls, ID, DOE Supplemental Directive ID 5481.1B.

Department of Energy, (DOE 1990), Safety Performance Measurement System (SPMS) Users Manual, DOE, Washington, DC.

Department of Energy (DOE 1988a), Internal Dose Conversion Factors for Calculation of Dose to the Public, DOE, Washington, DC, DOE/EH-0071.

Ermac, D. L. (1989), User's Manual for SLAB: An Atmospheric Dispersion Model for Denser-ThanAir Releases, Lawrence Livermore National Laboratory, Livermore, CA, UCRL-99882. 
Federal Emergency Management Agency. (FEMA 1989), U.S. Department of Transportation, U.S. Environmental Protection Agency, Handbook of Chemical Hazard Analysis Procedures, U.S. Government Printing Office, Washington, DC.

International Commission on Radiological Protection (ICRP 1975), Report of the Tasks Group on Reference Man, New York: Pergamon Press, ICRP Publication 23.

International Commission of Radiological Protection (ICRP 1977), Recommendations of the International Commission on Radiological Protection, New York: Pergamon Press, ICRP Publication 26.

Napier, B.A. (1988), GENII-The Hanford Environmental Radiation Dosimetry Software System, Volume 1, 2, 3, Pacific Northwest Laboratory, PNL-6584.

National Institute for Occupational Safety and Health (NIOSH 1990), NIOSH Pocket Guide to Chemical Hazards, U. S. Department of Health and Human Services, Washington, DC, June 1990.

Northeast Utilities Service Company (NUSCO), Probabilistic Safety Analysis of Heavy Load Handling Operations Hadden Neck-Millstone Unit 2," NUSCO 136, September 1983.

Wenzel, D. R. (1993), Draft: The Radiological Safety Analysis Computer Program (RSAC-5), Idaho Falls, ID. WINCO-1123.

Williams, A.C. (1993), Interim Guidelines for Compliance with Safety Analysis Requirements on Environmental Remediation and D\&D Activities at the INEL, Revision 0, letter to distribution, ERWM-RPO-419-93. 
Appendix 3A

\section{Example Accident Analysis}


3A-2 


\section{Appendix 3A}

\section{Example Hazard and Accident Analysis}

\section{A-1. INTRODUCTION}

This appendix has been developed as an example of the process described in Chapter 3. The activity being analyzed is the removal of a 1,000-gal hot waste underground storage tank as part of a D\&D activity. The tank is empty except for a 3-in. layer (about $0.1 \mathrm{~m}^{3}$ ) of sludge in the bottom containing radionuclides, cadmium, and acetone. The tank is located outside and no temporary structure will be erected before removal.

\section{A-2. REQUIREMENTS}

The requirements section in the main text would be used here and is not repeated for this example.

\section{A-3. HAZARD ANALYSIS}

\section{A-3.1 Methodology}

This section presents the methodology used to identify, characterize, and perform a systematic evaluation of hazards associated with removal of the tank.

\section{A-3.1.1 Hazard Identification}

The checklists presented in Section 3.3.2.1 of the main text were used to identify hazards for the activity. The completed checklists are presented in Tables 3A-1 and 3A-2. The radioactive and hazardous chemical inventories came from previous sampling data.

\section{A-3.1.2 Hazard Evaluation}

The table presented in Section 3.3.2.3 of the main text was used to identify hazards for the activity. The completed table is presented as Table 3-7 in the main text.

\section{A-3.2 Hazard Analysis Results}

\section{A-3.2.1 Hazard Identification}

Hazards associated with the activity are identified in Tables 3A-1 and 3A-2. Inert and low-oxygen atmosphere, excavation, and mechanical and moving equipment dangers are potential hazards associated with the activity but will not be analyzed further because they are adequately covered by DOE-prescribed OSH standards and they will not lead to a release of radionuclides or hazardous chemicals. Flammable gases and liquids, toxic substances, radioactive materials, 
Table 3A-1. Occupational hazard analysis checklist.

\begin{tabular}{|c|c|c|c|}
\hline Hazard & Applicable & Explanation & $\begin{array}{l}\text { DOE-prescribed OSH } \\
\text { standards }\end{array}$ \\
\hline $\begin{array}{l}\text { High voltage } \\
(\geq 600 \mathrm{~V})\end{array}$ & No & Not applicable to the activity. & - \\
\hline Low voltage $(<600 \mathrm{~V})$ & No & Not applicable to the activity & \\
\hline $\begin{array}{l}\text { Flammable gases, liquids, } \\
\text { dusts }\end{array}$ & Yes & Acetone is present in the tank & \\
\hline Explosive materials & No & Not applicable to the activity & \\
\hline Cryogenic systems & No & Not applicable to the activity & \\
\hline High temperature/pressures & No & Not applicable to the activity & \\
\hline $\begin{array}{l}\text { Inert and low-oxygen } \\
\text { atmospheres }\end{array}$ & Yes & $\begin{array}{l}\text { Tank is a possible low-oxygen } \\
\text { atmosphere; however, } \\
\text { personnel will not enter the } \\
\text { tank during the activity. } \\
\text { Therefore, this hazard will not } \\
\text { be analyzed further }\end{array}$ & $\begin{array}{l}29 \text { CFR } 1910.120, .252, .1200 \\
29 \text { CFR } 1926.651\end{array}$ \\
\hline Toxic substances & Yes & Identified in material inventory & . \\
\hline Nonionizing radiation & No & Not applicable to the activity & \\
\hline $\begin{array}{l}\text { High-intensity magnetic } \\
\text { fields }\end{array}$ & No & Not applicable to the activity & \\
\hline High noise levels & No & Not applicable to the activity & \\
\hline $\begin{array}{l}\text { Mechanical and moving } \\
\text { equipment dangers }\end{array}$ & Yes & $\begin{array}{l}\text { The equipment used to remove } \\
\text { the tank is considered standard } \\
\text { industrial hazards and will not } \\
\text { be analyzed further }\end{array}$ & $\begin{array}{l}29 \text { CFR } 1910.147, .211-.222 \\
29 \text { CFR } 1926, \text { Subpart W }\end{array}$ \\
\hline Working at heights & No & Not applicable to the activity & \\
\hline Excavation & Yes & $\begin{array}{l}\text { Once the tank is removed the } \\
\text { hole will be filled in. This is } \\
\text { not analyzed further }\end{array}$ & 29 CFR 1926, Subpart P \\
\hline Material-handling dangers & Yes & $\begin{array}{l}\text { The crane to remove the tank } \\
\text { will be operated according to } \\
\text { the DOE Hoisting and Rigging } \\
\text { Manual. This is not analyzed } \\
\text { further }\end{array}$ & $\begin{array}{l}29 \text { CFR 1910.120, .176, .178 - } \\
.182 ; 29 \text { CFR 1926.953; DOE } \\
\text { Hoisting and Rigging Manual } \\
\text { (DOE 1993) }\end{array}$ \\
\hline Pesticide use & No & Not applicable to the activity & \\
\hline $\begin{array}{l}\text { Temperature extremes (for } \\
\text { example, high and low } \\
\text { temperatures during } \\
\text { activities) }\end{array}$ & No & $\begin{array}{l}\text { High temperatures are not } \\
\text { anticipated during the activity }\end{array}$ & \\
\hline Inadequate illumination & No & $\begin{array}{l}\text { The tank is located outside and } \\
\text { illumination is not a problem }\end{array}$ & \\
\hline Construction & No & Not applicable to the activity & \\
\hline
\end{tabular}


Table 3A-2. Material and energy source hazard analysis checklist.

\begin{tabular}{llll}
\hline \multicolumn{1}{c}{ Hazard } & Applicable & & \multicolumn{1}{c}{ Explanation } \\
\hline Radioactive material & Yes & Identified in material inventory \\
Fissionable or fissile & No & No fissionable material identified \\
Alkali metal & No & Not applicable to activity \\
Corrosive & No & Not applicable to activity \\
Natural phenomena & Yes & Seismic or high winds may cause a release of hazardous chemicals or \\
& radioactive materials \\
Fire & Yes & Acetone is present in the tank, creating a potential source of fire \\
Interfaces & No & Not applicable to activity \\
Waste disposal & No & Not applicable to activity \\
Maintenance & No & Not applicable to activity \\
Security & No & Not applicable to activity \\
\hline
\end{tabular}

material-handling dangers, fire, and natural phenomena are potential hazards that will be analyzed further.

\section{A-3.2.2 Hazard Classification}

The hazard classification is based on the source term of radionuclides and hazardous materials. The source term is taken from previous sampling and analysis performed on the tank contents. The radionuclide source term is compared to Hazard Category 3 threshold quantities (TQ) listed in DOE-STD-1027-92 and reportable quantities (RQ) listed in 40 CFR 302. The hazardous chemical source term is compared to the TQs listed in 29 CFR 1910.119, threshold planning quantities (TPQ) listed in 40 CFR 355, and RQs listed in 40 CFR 302.

The radionuclide source term and guidance levels are listed in Table 3A-3. Facilities with combinations of radioactive materials are designated Hazard Category 3 if the sum of the ratios of the quantities of each material divided by the Category 3 thresholds exceeds one. The sum of the ratios is 0.96 (Column 4 ) indicating that the activity is not a Category 3 hazard. The inventory values for cesium and strontium exceed the $R Q$ values, and the sum of the ratios is greater than one. Therefore, the activity is classified as a radiological activity in accordance with DOE-EMSTD-5502-94 guidelines.

The hazardous chemical source term and guidance levels are listed in Table 3A-4. The chemical inventory has been converted to kilograms (listed in Column 2) by multiplying the inventory source term (expressed in $\mathrm{mg} / \mathrm{kg}$ ), by $1500 \mathrm{~kg} / \mathrm{m}^{3}$ (sludge density), $0.1 \mathrm{~m}^{3}$ (volume of sludge present), and $1 \mathrm{E}-06 \mathrm{~kg} / \mathrm{mg}$ (conversion factor). The chemical inventory does not exceed the reportable quantity values and does not affect the classification of the activity. 
Table 3A-3. Radionuclide inventory.

\begin{tabular}{|c|c|c|c|c|c|}
\hline Radionuclide & $\begin{array}{l}\text { Inventory } \\
\text { (Ci) }\end{array}$ & $\begin{array}{l}\text { Category } 3 \\
\text { threshold } \\
\text { quantity } \\
\text { (Ci) }\end{array}$ & Ratio & $\begin{array}{l}\text { Reportable } \\
\text { quantities } \\
\text { value } \\
\text { (Ci) }\end{array}$ & Ratio \\
\hline${ }^{60} \mathrm{Co}$ & $4.0 \mathrm{E}+00$ & 280 & $1.4 \mathrm{E}-02$ & $1.0 \mathrm{E}+01$ & $4.0 \mathrm{E}-01$ \\
\hline${ }^{137} \mathrm{Cs}$ & $1.2 \mathrm{E}+01$ & 60 & $2.0 \mathrm{E}-01$ & $1.0 \mathrm{E}+00$ & $1.2 \mathrm{E}+01$ \\
\hline${ }^{137}{ }^{m} \mathrm{Ba}$ & $1.1 \mathrm{E}+01$ & NA & NA & & $\mathrm{NA}$ \\
\hline${ }^{90} \mathrm{Sr}$ & $1.2 \mathrm{E}+01$ & 16 & $7.5 \mathrm{E}-01$ & 1.0E-01 & $1.2 \mathrm{E}+02$ \\
\hline Total & 39 & Ratio sum & 0.96 & Ratio sum & $1.3 E+02$ \\
\hline \multicolumn{6}{|c|}{$\begin{array}{l}\mathrm{NA}={ }^{137 \mathrm{~m}} \mathrm{Ba} \text { is not listed in Attachment } 1 \text { of DOE-STD-1027-92 (DOE 1992). For isotopes not listed, } \\
\text { users may contact DOE-Headquarters, Office of Nuclear Safety Policy and Standards (EH-60), for } \\
\text { threshold quantities of any isotopes of interest. For the case of }{ }^{137 \mathrm{~m}} \mathrm{Ba} \text {, the listed threshold quantity for } \\
{ }^{137} \mathrm{Cs} \text { has taken the effects of }{ }^{137 \mathrm{~m}} \mathrm{Ba} \text { into account. Therefore, a threshold quantity for }{ }^{137 \mathrm{~m}} \mathrm{Ba} \text { is not } \\
\text { listed and does not need to be included when determining the ratio. Because this methodology is not } \\
\text { necessarily true for other isotopes not listed, EH- } 60 \text { should always be contacted on a case-by-case basis. }\end{array}$} \\
\hline
\end{tabular}

Table 3A-4. Chemical inventory.

\begin{tabular}{lcccc}
\hline \multicolumn{1}{c}{ Chemical } & $\begin{array}{c}\text { Inventory } \\
(\mathrm{mg} / \mathrm{kg})\end{array}$ & $\begin{array}{c}\text { Inventory } \\
(\mathrm{kg})\end{array}$ & $\begin{array}{c}\text { Reportable quantity } \\
\text { value } \\
(\mathrm{kg})\end{array}$ & Ratio \\
\hline Cadmium & 4.5 & $6.8 \mathrm{E}-04$ & $4.54 \mathrm{E}+00$ & $1.5 \mathrm{E}-04$ \\
Acetone & $3.1 \mathrm{E}+03$ & $4.7 \mathrm{E}-01$ & $2.27 \mathrm{E}+03$ & $2.1 \mathrm{E}-04$ \\
& & & Ratio sum & $3.6 \mathrm{E}-04$ \\
\hline
\end{tabular}

\section{A-3.2.3 Hazard Evaluation}

The hazard evaluation for this example is given in Table 3-7 and is not repeated in this appendix.

3A-3.2.3.1 Planned Design and Operational Safety Improvements. This section is not applicable to this example.

3A-3.2.3.2 Defense in Depth. The activity has been designated as a radiological activity. TSRs are not required for radiological activities. Therefore, no safety-significant structures, systems, or components are identified for this activity. However, administrative guidelines have been implemented to prevent worker exposure to radioactive materials or hazardous chemicals. In addition, the tank protects the worker from direct contact with the contaminants. The 
contaminants are not readily dispersible because they are mixed with the sludge, and a fire watch will be present during the cutting operation. Each of these is a defense-in-depth concept that protects the worker from exposure.

3A-3.2.3.3 Worker Safety. 'The worker is protected from hazards through the use of administrative guidelines. The tank is located outside and no confinement will be erected over the area during removal. Therefore, the workers will be protected from exposure to hazardous chemicals and radiological materials through the use of personal protective equipment, which is identified in the Health and Safety Plan. Other administrative guidelines include inspection of the site, lifting equipment, and vehicles at the beginning of each day the activity is being performed. Detailed operational procedures will be developed and followed during the activity.

3A-3.2.3.4 Environmental Protection. The net environmental impact of removing the tank will be completely beneficial because a possible source of contamination will be removed. It is anticipated that any environmental perturbations would be temporary and totally restorable in nature. A spill kit and spill prevention control and countermeasures plan will be part of the activity to mitigate any adverse effects from an accident.

3A-3.2.3.5 Accident Selection. The three accidents listed in Table 3-7 (fire, drop, and natural phenomena) are evaluated qualitatively to determine the bounding scenario. Natural phenomena are determined to be "incredible" scenarios. Because of the short duration of the activity, the greatest consequence would be that the tank splits open and the contents are exposed to the environment. It is assumed that dropping the tank during lifting will also expose the contents to the environment. However, a fire would cause the contaminants to be dispersed. Therefore, it is determined that fire will be the bounding accident and will be analyzed further in Section 3A-3.3.

\section{A-4. ACCIDENT ANALYSIS}

The fire accident scenario was determined to be the bounding accident requiring further evaluation. The accident analysis is performed to show that the operation will not have offsite consequences and to determine the consequences to the worker.

\section{A-4.1 Methodology}

The accident analysis methodologies presented in Sections 3.4.1.1 and 3.4.1.2 of the main text are used to analyze the fire hazard. The methodology is not repeated here, but the calculations are presented in Section 3A-4.2.3.

\section{A-4.2 Bounding Accident-Fire during Cutting Torch Operations}

\section{A-4.2.1 Scenario Development}

A 1,000-gal hot waste tank is to be removed as part of a D\&D activity. The tank is empty except for a 3-in. layer of sludge in the bottom, about $0.1 \mathrm{~m}^{3}$, containing radionuclides, cadmium, and acetone. Part of the removal process involves cutting the inlet pipe from the tank with a 
torch. The worker fails to comply with operating procedures or the procedures fail to require checking and monitoring for flammable vapors and/or liquids and the acetone in the sludge is ignited during the cutting torch operation. The fire burns to completion in $30 \mathrm{~min}$ when the acetone is consumed.

\section{A-4.2.2 Source Term Analysis}

The accident calculations will not include any mitigative equipment. Therefore, the source term will be the same as shown in Tables $3 \mathrm{~A}-3$ and $3 \mathrm{~A}-4$.

\section{A-4.2.3 Consequence Analysis}

The consequence analysis is presented in two parts, one for the worker $(<100 \mathrm{~m})$ and one for the public $(>100 \mathrm{~m})$.

3A-4.2.3.1 D\&D Worker $(<100 \mathrm{~m})$. The exposure estimates from the workers inhaling contaminants from the fire are calculated using the following equation:

$\mathrm{WECED}=\mathrm{RC} \times \mathrm{BR} \times \mathrm{ED} \times \mathrm{DCF}$

where

$$
\begin{array}{ll}
\text { WECED } & =\text { worker exposure committed effective dose equivalent (CEDE) } \\
\mathrm{RC} & =\text { radionuclide concentration }\left(\mathrm{Ci} / \mathrm{m}^{3}\right) \\
\mathrm{BR} & =\text { breathing rate }=3.33 \mathrm{E}-04\left(\mathrm{~m}^{3} / \mathrm{s}\right)(\mathrm{DOE} 5480.11) \\
\mathrm{ED} & =\text { exposure duration }=2 \mathrm{~min} \\
\mathrm{DCF} & =\text { dose conversion factor from DOE/EH-0071 (DOE 1988a). }
\end{array}
$$

The $\mathrm{RC}$ is calculated by multiplying the amount of each radionuclide present in the sludge by the airborne release fraction (ARF) of 5.0E-03 and dividing the result by the plume volume (assumed to be $1,200 \mathrm{~m}^{3}$ ). For this scenario, 5.0E-03 was assumed because the outdoor fire involved nonvolatile radionuclides in an aqueous solution under the fire (DOE 1994c). The plume volume is a best engineering estimate for the size of a plume that forms, assuming stagnant air conditions. There are no concurring references; however, given that the fire occurs outside at the INEL, it is likely that wind will disperse this plume and reduce its concentration of radionuclides and hazardous materials. The RF and DR are both conservatively assumed to be $100 \%$. Chapter 3 Section 3.4.1.1 of the main text provides airborne release fraction guidance.

Using the data presented in Table $3 \mathrm{~A}-3$ (specifically ${ }^{60} \mathrm{Co}$ for illustrative purposes), the WECED is calculated as follows: 


$$
\begin{aligned}
\text { WECED } & \left.=((5 E-03)(4.0 \mathrm{Ci})) / 1200 \mathrm{~m}^{3}\right) \times\left(3.33 \mathrm{E}-04 \mathrm{~m}^{3} / \mathrm{sec}\right) \times(120 \mathrm{sec}) \times(1.5 \mathrm{E}+5 \mathrm{rem} / \mathrm{Ci}) \\
& =1.0 \mathrm{E}-01 \mathrm{rem} \mathrm{CEDE} .
\end{aligned}
$$

The exposure estimates for all the radionuclides present are summarized in Table 3A-5.

Potential worker exposure to cadmium is determined using the methodology presented in Chapter 3 Section 3.4.1.2 of the main text. The release duration is assumed to be $30 \mathrm{~min}$, the time for the fire to burn completely. Worker exposure time is assumed to be $2 \mathrm{~min}$. (Procedures call for the workers to evacuate the area and allow trained fire fighters to combat any fire.) The plume volume is assumed to be $1200 \mathrm{~m}^{3}$, as before. Because the cadmium is a particulate in the sludge, the 5E-03 airborne release fraction applies. As in the radionuclide worker exposure calculation, the respirable fraction and damage ratio are both conservatively assumed to be $100 \%$.

Using the relationship,

Concentration affecting onsite workers $\mathrm{mg} / \mathrm{m}^{3}=(\mathrm{Q} \times \mathrm{T}) /(\mathrm{RD} \times \mathrm{V})$

where

$$
\begin{aligned}
& \mathrm{Q}=\text { quantity of hazardous material released (mg or fibers) } \\
& \mathrm{T}=\text { worker exposure time (s) } \\
& \mathrm{RD}=\text { release duration (s) } \\
& \mathrm{V}=\text { plume volume }
\end{aligned}
$$

and inserting the numerical values, yields

$$
1.89 \mathrm{E}-4 \mathrm{mg} / \mathrm{m}^{3}=[(680 \mathrm{mg} \times 5 \mathrm{E}-03) \times 2 \mathrm{~min}] /\left(30 \mathrm{~min} \times 1,199.5 \mathrm{~m}^{3}\right) \text {. }
$$

The TLV-TWA for cadmium is $0.002 \mathrm{mg} / \mathrm{m}^{3}$ (respirable fraction of dust). This is an average concentration over an 8-hr period. To compare the cadmium concentration affecting onsite workers with this TLV-TWA, the time-weighted 8-hr TWA exposure is calculated as follows:

7.8E-07 $\mathrm{mg} / \mathrm{m}^{3}=1.89 \mathrm{E}-04 \mathrm{mg} / \mathrm{m}^{3} \times 2 \mathrm{~min} . / 480 \mathrm{~min}$. 
Table 3A-5. Worker exposure to radionuclides.

\begin{tabular}{lccc}
\hline \multicolumn{1}{c}{ Radionuclide } & Inventory $(\mathrm{Ci})$ & $\begin{array}{c}\text { Conversion factor } \\
(\mathrm{rem} / \mathrm{Ci})^{\mathrm{a}}\end{array}$ & $\begin{array}{c}\text { CEDE } \\
(\mathrm{rem})\end{array}$ \\
\hline${ }^{60} \mathrm{Co}$ & $4.0 \mathrm{E}+00$ & $1.5 \mathrm{E}+05$ & $1.0 \mathrm{E}-01$ \\
${ }^{137} \mathrm{Cs}$ & $1.2 \mathrm{E}+01$ & $3.2 \mathrm{E}+04$ & $6.4 \mathrm{E}-02$ \\
${ }^{137 \mathrm{~m}} \mathrm{Ba}$ & $1.1 \mathrm{E}+01$ & $3.2 \mathrm{E}+04$ & $5.9 \mathrm{E}-02$ \\
${ }^{90} \mathrm{Sr}$ & $1.2 \mathrm{E}+01$ & $1.3 \mathrm{E}+06$ & $2.6 \mathrm{E}+00$ \\
\cline { 2 - 2 } & Total 3.9E+01 & & Total CEDE 2.8E+00
\end{tabular}

a. The rem/Ci conversion factors are applicable for both the worker and the public.

3A-2.2.3.2 Downwind receptors $(>100 \mathrm{~m}$ )-To calculate the downwind radiological consequences, an accident source term is determined using the following equation:

$\mathrm{AST}=\mathrm{MAR} \times \mathrm{CF} \times \mathrm{DR} \times \mathrm{RF} \times \mathrm{ARF}$

where

$$
\begin{aligned}
& \text { MAR }=\text { Material at risk }=0.1 \mathrm{~m}^{3} \\
& \mathrm{CF}=\text { Concentration factor }=390 \mathrm{Ci} / \mathrm{m}^{3} \\
& \mathrm{DR}=\text { Damage ratio }=1.0 \\
& \mathrm{ARF}=\text { Airborne release fraction }=5.0 \mathrm{E}-03 \\
& \mathrm{RF}=\text { Respirable fraction }=1.0 \\
& \mathrm{AST}=\text { Accident source term }(\mathrm{Ci}) .
\end{aligned}
$$

Therefore,

$\mathrm{AST}=0.1 \mathrm{~m}^{3} \times 390 \mathrm{Ci} / \mathrm{m}^{3} \times 5 \mathrm{E}-03=1.95 \mathrm{E}-01 \mathrm{Ci}$

The AST is multiplied by the individual fraction of each radionuclide to determine the curie content input for RSAC. This inventory is presented in Table $3 \mathrm{~A}-6$. For example, for ${ }^{60} \mathrm{Co}$

RSAC input inventory $=4.0 \mathrm{Ci} / 39 \mathrm{Ci} \times 1.95 \mathrm{E}-01 \mathrm{Ci}=2 \mathrm{E}-02 \mathrm{Ci}$ of ${ }^{60} \mathrm{Co}$. 
Table 3A-6. Determination of RSAC inventory input.

\begin{tabular}{cccc}
\hline Radionuclide & $\begin{array}{c}\text { Inventory } \\
(\mathrm{Ci})\end{array}$ & $\begin{array}{c}\text { Inventory } \\
\text { fraction }\end{array}$ & $\begin{array}{c}\text { RSAC } \\
\text { inventory input } \\
(\mathrm{Ci})\end{array}$ \\
\hline${ }^{60} \mathrm{Co}$ & $4.0 \mathrm{E}+00$ & 0.1 & $2.0 \mathrm{E}-02$ \\
${ }^{137} \mathrm{Cs}$ & $1.2 \mathrm{E}+01$ & 0.3 & $6.0 \mathrm{E}-02$ \\
${ }^{137 m} \mathrm{Ba}$ & $1.1 \mathrm{E}+01$ & 0.3 & $5.5 \mathrm{E}-02$ \\
${ }^{90} \mathrm{Sr}$ & $1.2 \mathrm{E}+01$ & 0.3 & $6.0 \mathrm{E}-02$ \\
\hline
\end{tabular}

Using the criteria and input requirements from the RSAC Manual (Wenzel 1993), the data in Table 3A-4, were input into the RSAC code to determine the potential doses at $100 \mathrm{~m}$, $1,000 \mathrm{~m}$, and 10,607 m. These distances were selected to represent the collocated worker and the public at Highway 20/26 and at the nearest INEL site boundary. The Markee sigmas for releases between 15 and $60 \mathrm{~min}$ and an air stability Class $\mathrm{F}$ were chosen. A wind speed of $1.04 \mathrm{~m} / \mathrm{sec}$ is used as explained in Chapter 1 Section 1.4.1.4 of the main text. The downwind exposures were calculated based on the time necessary for $100 \%$ release. The results of these calculations are presented in Table 3A-7. The inhalation dose for the onsite worker (calculated in the previous section) is also presented in Table 3A-7. The actual code input is included as Section 3A-5.

Downwind receptors exposure to the cadmium would be less than that calculated previously for the worker. Because the calculated value is well below the TLV-TWA, it is not necessary to perform calculations for downstream receptors. However, the calculations are presented below for illustrative purposes. The more conservative $\chi / \mathrm{Q}$ values from RSAC calculations that used air stability Class F were employed. The release duration is $30 \mathrm{~min}(1,800 \mathrm{sec})$ and the ARF is $5 \mathrm{E}-03$, as used previously for the radionuclide calculations.

Concentration affecting downwind receptors $\left(\mathrm{mg} / \mathrm{m}^{3}\right)=[(\mathrm{Q}) \times(\mathrm{DC})] / \mathrm{RD}$

where

$\mathrm{Q}=$ quantity of hazardous material released ( $\mathrm{mg}$ or fibers)

$\mathrm{DC}=$ dispersion coefficient $(\chi / \mathrm{Q})$ for specific downwind receptor. The values are obtained from the R.SAC calculations

RD. $=$ release duration (s).

At $100 \mathrm{~m}$,

$7.71 \mathrm{E}-06 \mathrm{mg} / \mathrm{m}^{3}=(680 \mathrm{mg})(5 \mathrm{E}-03)\left(4.081 \mathrm{E}-03 \mathrm{~s} / \mathrm{m}^{3} / 1800 \mathrm{~s}\right)$. 
Table 3A-7. Calculated exposures.

\begin{tabular}{|c|c|c|c|c|}
\hline Pathway & $\begin{array}{l}\text { Worker }^{a} \\
\text { (rem) }\end{array}$ & $\begin{array}{l}\text { Co-located worker } \\
\text { (rem) }(100 \mathrm{~m})\end{array}$ & $\begin{array}{l}\text { Highway } 20 / 26 \\
(\mathrm{rem})(1,000 \mathrm{~m})\end{array}$ & $\begin{array}{c}\text { Nearest site } \\
\text { boundary } \\
\text { (rem) }(10,607 \mathrm{~m})\end{array}$ \\
\hline Inhalation & 2.8 & $2.54 \mathrm{E}-02^{\mathrm{b}}$ & $1.75 \mathrm{E}-03$ & 1.13E-04 \\
\hline Ingestion & NA & NA & NA & $6.96 \mathrm{E}-03$ \\
\hline Ground surface & NA & $2.36 \mathrm{E}-02$ & $1.63 \mathrm{E}-03$ & 1.05E-04 \\
\hline Air immersion & NA & $5.98 \mathrm{E}-05$ & 4.15E-06 & $2.67 \mathrm{E}-07$ \\
\hline Total & 2.8 & 4.91E-02 & $3.38 \mathrm{E}-03$ & $7.18 \mathrm{E}-03$ \\
\hline \multicolumn{5}{|c|}{ a. Independent of stability class. } \\
\hline \multicolumn{5}{|c|}{ b. Class F stability. } \\
\hline
\end{tabular}

At $1,000 \mathrm{~m}$,

$5.30 \mathrm{E}-07 \mathrm{mg} / \mathrm{m}^{3}=(680 \mathrm{mg})(5 \mathrm{E}-03)\left(2.807 \mathrm{E}-04 \mathrm{~s} / \mathrm{m}^{3} / 1800 \mathrm{~s}\right)$

At $10,607 \mathrm{~m}$,

$3.41 \mathrm{E}-08 \mathrm{mg} / \mathrm{m}^{3}=(680 \mathrm{mg})(5 \mathrm{E}-03)\left(1.807 \mathrm{E}-05 \mathrm{~s} / \mathrm{m}^{3} / 1800 \mathrm{~s}\right)$.

\section{A-4.2.4 Comparison to Guidelines}

Cadmium concentrations to the worker and the public are below the TLV guidelines. Radiation exposure is limited to $3 \mathrm{rem}$ for the worker and $0.01 \mathrm{rem}$ for the public. The worker and co-located worker exposures are below the 3-rem limit. The public dose is below the 0.01-rem guideline. Therefore, this activity will not expose the worker or the public to quantities of radionuclides or hazardous chemicals above the guidance limits.

\section{A-4.2.5 Summary of Safety-Class SSCs and TSR Controls} controls.

This activity is below a Category 3 hazard and does not have safety-significant SSCs or TSR 


\section{A-5. RSAC INPUT DATA}

*BSAF Tank Release Calculations

\# Radionuclide inventory

2000,0

$\mathrm{CO} 60,0.02$

SR $90,0.06$

CS137,0.06

BA137M,0.055

2999

\# Meteorological data

5000

$5000,1.04,0,400 ., 1.099 \mathrm{E} 3,0,0$

$5002, .001, .01,0 ., .001, .001$

$5101,100 ., 1000 ., 10607$.

5201, 1.,0

$5400,2,0,0,0$

$5410,2,6,0$

5999

\# Inhalation calculation

$7000,0,-2,1,0,1$

7001,3.33E-4,0,0,0

7999

\# Ingestion calculation

$7000,3,-2,1,0,1$

$7001,0,0,0,0$

$7004,0,1,30 ., 7$.

7999

\# Ground surface calculation

$7000,4,-2,1,0,1$

$7001,0,0,0,0$

7999

\#Air immersion calculation

$7000,5,-2,1,0,1$

$7001,0,0,0,0$

7999

10000 
3A-14 


\section{SAFETY STRUCTURES, SYSTEMS, AND COMPONENTS}

\subsection{Introduction}

This chapter identifies and describes facility structures, systems, and components (SSCs) that are necessary for environmental restoration (ER) program and Decontamination and Dismantlement (D\&D) activities to satisfy offsite evaluation guidelines and ensure worker safety.

\subsection{Requirements}

The following Codes of Federal Regulations, U.S. Department of Energy (DOE) orders, and other requirements are applicable to this chapter and are implemented by Lockheed Idaho Technologies Company:

- $\quad 10$ CFR 835, "Occupational Radiation Protection"

- $\quad 29$ CFR 1910, "Occupational Safety and Health Standards"

- DOE Order 5480.7A, "Fire Protection," February 17, 1993

- DOE Order 5480.11, "Radiation Protection for Occupational Workers," June 17, 1992

- $\quad$ DOE Order 5480.21, "Unreviewed Safety Questions," December 24, 1991

- DOE Order 5480.22, "Technical Safety Requirements," September 15, 1992

- DOE Order 5480.23, "Nuclear Safety Analysis Reports," March 10, 1994

- DOE Order 5480.28, "Natural Phenomena Hazards Mitigation," January 15, 1993

- DOE Order 5700.6C, "Quality Assurance," August 21, 1991

- $\quad$ DOE Order 6430.1A, "General Design Criteria," April 6, 1989

- American Concrete Institute, ACI 349, "Code Requirements for Nuclear Safety Related Concrete Structures"

- American Welding Society, AWS D1.1, D1.2, or D1.4, "Structural Welding Code."

\subsection{Safety-Class Systems, Structures, and Components}

Safety-class SSCs are those that either prevent or mitigate accidents whose consequences are greater than the evaluation guidelines for offsite personnel. The Baseline Safety Analysis File is written to cover ER program and D\&D activities classified as Hazard Category 3 (those that pose a significant localized hazard) as defined in DOE Order 5480.23 with further guidance established in DOE-Standard (STD)-1027-92 (LOE 1992) or are less than Hazard Category 3. By definition, 
the accident analysis in Chapter 3 should show that none of the offsite evaluation guidelines are exceeded during accident conditions. Therefore, there are no safety-class SSCs required for ER program and D\&D activities. If the evaluation guidelines are exceeded, this section would contain information on the safety-class SSCs associated with the activity.

\subsection{Safety-Significant Structures, Systems, and Components}

DOE-Standard (STD)-3009-94 (DOE 1994) defines safety-significant SSCs as:

Structures, systems, and components not designated as safety-class SSCs but whose preventive or mitigative function is a major contributor to defense in depth (i.e., prevention of uncontrolled material releases) and/or worker safety as determined from hazard analysis.

Safety-significant SSCs designations based on worker safety are limited to the SSCs whose failure is estimated to result in an acute worker fatality or serious injuries to workers. Serious injuries, as used in this definition, refers to medical treatment for immediately life-threatening or permanently disabling injuries (e.g., loss of eye, loss of limb) from other than standard industrial hazards. It specifically excludes potential latent effects (e.g., potential carcinogenic effects of radiological exposure or uptake).

This section should provide a summary of the safety-significant SSCs that have been identified in Chapter 3 that require technical safety requirement (TSR) coverage. The summary could be in the form of a table that would include identifying each safety-significant SSC, the rationale from Chapter 3 for which safety-significant designation was made, safety functions, functional requirements, and performance criteria judged to require TSR coverage. The remaining subsections provide details that correlate to the summary list.

\subsection{Applicable Safety-significant System, Structure, or Component}

The title will identify the safety-significant SSC.

4.4.X.1 Safety Function. This subsection should state the reason for designating the SSC as a safety-significant SSC, followed by specific identification of its preventive or mitigative safety function(s) as determined in Chapter 3. The specific accident(s) or general rational associated with the safety function should be identified.

4.4.X.2 System Description. This subsection provides a description of the safetysignificant SSC and the basic principles by which it performs its safety function.

4.4.X.3 Functional Requirements. This subsection identifies requirements that are specifically needed to fulfill safety functions. Such functional requirements are specified for both the safety-significant SSC and any needed support safety-significant SSCs. Functional requirements should address the pertinent response parameters or nonambient environmental stresses related to an accident for which the safety function is being relied upon. 
4.4.X.4 System Evaluation. This subsection should document the evaluation of the SSC to meet performance criteria related to its safety function. The performance criteria should be identified along with how the SSC satisfies the criteria.

4.4.X.5 Controls (TSRs). This subsection identifies those assumptions requiring TSRs to ensure performance of the safety function. 


\subsection{References}

Department of Energy (DOE 1992), Hazard Characterization and Accident Analysis Techniques for Compliance with DOE Order 5480.23, Nuclear Safety Analysis Reports, DOE, Washington, DC, DOE-STD-1027-92.

Department of Energy (DOE 1994), Preparation Guide for U.S. Department of Energy

Non-Reactor Nuclear Facility Safety Analysis Reports, DOE, Washington, DC, DOE-STD-3009-94. 


\section{DERIVATION OF TECHNICAL SAFETY REQUIREMENTS}

\subsection{Introduction}

Technical safety requirements (TSRs) are defined in U.S. Department of Energy (DOE) Order 5480.22, "Technical Safety Requirements," 1992, as "Those requirements that define the conditions, safe boundaries, and the management or administrative controls necessary to ensure the safe operation of a nuclear facility and to reduce the potential risk to the public and facility workers from uncontrolled releases of radioactive materials or from radiation exposures due to inadvertent criticality." TSRs are developed to ensure safe operation of environmental restoration (ER) program and Decontamination and Dismantlement (D\&D) activities.

This chapter is written to cover ER program and D\&D activities classified as Hazard Category 3 (those that pose a signilicant localized hazard) as defined in DOE Order 5480.23, "Nuclear Safety Analysis Reports," 1992, with further guidance established in DOE-Standard (STD)-1027-92. Therefore, Baseline Safety Analysis File (BSAF) TSRs are not required to protect the health and safety of the public, but are used to minimize the worker risk from uncontrolled releases of radioactive or other hazardous materials. The TSRs define requirements and operating conditions to ensure the risk from ER program and D\&D activities to onsite workers are maintained at acceptable levels. Criticality hazards are not addressed by the BSAF because they are classified as Category 2 Hazards.

TSRs are not required for activities that pose risk to workers below the Hazard Category 3 threshold levels and are exempt from the safety analysis requirements of DOE Order 5480.23. The administrative controls required by BSAF may be applicable but are not considered TSRs for these type of activities.

The TSRs for the specific activity will be provided in a separate document. This chapter provides the link between the accident analyses (Chapter 3 ) to the TSR document as required by DOE Order 5480.23. The TSRs are derived using information contained in this chapter.

\subsection{Requirements}

The following standards, regulations, and DOE orders are applicable to this chapter:

- DOE Order 5000.3B, "Occurrence Reporting and Processing of Operations Information," January 19, 1993, CHG 1, July 2, 1993.

- DOE Order 5480.10, "Contractor Industrial Hygiene Program," June 26, 1985

- $\quad$ DOE Order 5480.22, "Technical Safety Requirements," September 15, 1992

- DOE-STD-1027-92, "Hazard Characterization and Accident Analysis Techniques for Compliance with DOE Order 5480.23, Nuclear Safety Analysis Reports." 


\subsection{TSR Coverage}

This section will ensure that TSR coverage for ER program and D\&D activities is complete. Any feature identified in Chapters 3 or 4 that is needed to (a) provide significant defense in depth, (b) provide for significant worker safety, or (c) maintain consequences of facility operations below evaluation guidelines shall be addressed. For ER program and D\&D activities, no structure, system, or component (SSC) falls under the first or third category. However, per the "Safety-Significant SSCs" section in Chapter 3, there may be some SSCs that may be designated as safety-significant. Therefore, administrative controls need to be in place during the activity to ensure the worker is protected.

\subsection{Derivation of Facility Modes}

This section describes the basic operational modes (e.g., startup, operation, shutdown) used by the activity that are relevant to derivation of TSRs. The definition of modes required in this subsection expands and formalizes the information provided in Chapter 3 regarding operational conditions associated with accidents and will be based on the activity-specific Safety Analysis Report (SAR).

\subsection{TSR Derivation}

Derivation of TSRs consists of summaries and references to pertinent sections of the SAR in which SSCs are assumed functional to prevent or mitigate the consequences of accidents. If SSCs are relied upon to produce dose reductions below evaluation guidelines or to significantly protect the worker, then TSRs need to be developed for the whole array of SSCs being relied upon in accordance with Sections 5.5.1 and 5.5.2. However, for this chapter, BSAF activities have been limited to those classified as Hazard Category 3. The unmitigated release of available radioactive materials has only the potential for localized consequences and should not require engineered safety features or safety class structures. Therefore, safety limits (SLs), limiting control settings (LCSs), limiting conditions for operation (LCOs), and associated surveillance requirements are normally not required and Sections 5.5.1 and 5.5.2 are not applicable. However, administrative controls are normally necessary for activities covered by the BSAF.

The following paragraphs describe the methodology used to derive TSRs for the Baseline TSR File or specific activities. TSRs are derived from an evaluation of commitments, defined as:

Any concept in the BSAF that (1) establishes guidelines for the operation, reliability, availability, or maintainability of any system or subsystem that is required for safe operation of a facility within the risk accepted by DOE; (2) limits the risk accepted by DOE; (3) establishes (directly or indirectly by reference) a parametric value that if changed could increase the risk relative to the safety or protection of workers, the public, or the environment.

The BSAF commitments are evaluated using the following four questions (criteria) to identify those commitments that require incorporation into the Baseline TSR File. To identify 
additional TSRs, the four questions should be applied to activity-specific SARs. One or more questions answered "yes" should be included as a TSR or a requirement within a TSR.

1. Does the commitment identify requirements with respect to personnel responsibilities, organization, staffing, support, qualification, or training necessary to ensure the activity is conducted safely?

Personnel's responsibilities and organization define who is responsible for the safe conduct of an activity and the chain of command. Staffing, support, qualification, and training define the appropriate personnel required to be at the work site and the required level of qualification for each position. Support may include personnel not directly essential on the work site, but potentially necessary if technical difficulties arise.

2. Does the commitment identify programmatic requirements relied upon for safe conduct of an activity (for example, radiation protection program)?

Some programs are implemented by procedure as these programs address requirements not related to safety (for example, audits and reporting). This criterion identifies those programs important to safe operation of an activity that should be elevated to a TSR level.

3. Does the commitment identify aspects of an activity that could affect the activity hazard classification?

Hazard classifications of some activities may change if the total inventory at a site is combined or if the hazard classification is based on inventories near the appropriate thresholds and an unexpected concentration is found. These situations would be controlled to ensure that the safety analysis remains an enveloping document. (Note: Commitments requiring administrative control TSRs to ensure the hazard classification of an activity will be located and maintained in activity-specific safety analyses documentation.)

4. Does the commitment identify reviews, audits, and reporting requirements considered to be important to ensuring safety?

Generally, these programs are implemented by procedure and need only be elevated to a TSR if important to ensuring safety.

\subsubsection{Safety Limits, Limiting Control Settings, and Limiting Conditions for Operation}

SLs are limits on process variables, which, if exceeded, could directly cause the failure of one or more of the barriers that normally prevent the uncontrolled release of radioactive or hazardous chemical materials, resulting in exposures that exceed the evaluation guidelines for offsite personnel. By definition, the accident analysis in Chapter 3 should show that none of the offsite evaluation guidelines are exceeded during accident conditions. Therefore, no SLs are required for ER program and D\&D activities. 
LCSs are instrument and process set points selected to protect the SLs; however, since there are no applicable SLs, there are no applicable LCSs.

LCOs are the lowest functional capability or performance level of safety-related SSCs and their support systems required for normal, safe operation of the facility. If any SSC is modelled as a barrier (preventive or mitigative feature) to the uncontrolled release of radioactive material to the onsite worker, then it should be classified as an LCO. However, most ER program and D\&D activities will not have barriers associated with the activity. Therefore, no LCOs will be required for most $E R$ program and $D \& D$ activities.

\subsubsection{Surveillance Requirements}

Surveillance requirements address testing, calibration, or inspection requirements to maintain operation of the facility within SLs, LCSs, and LCOs. Since there are no SLs, LCSs, or LCOs associated with ER program and D\&D activities, there are no surveillance requirements.

\subsubsection{Administrative Controls}

Administrative controls are those controls necessary to ensure that ER program and D\&D activities are conducted and maintained within the safety envelope defined in the activity-specific SAR. The administrative controls describe the relationship of organizations and management, training, procedures, minimum staffing requirements, review and audit requirements, reporting and record keeping, and treatment of reportable occurrences dealing with safe operations. The violation of an administrative control is a violation of the TSR and must be reported accordingly. Included in this section are the recommended administrative controls noted in the "Potential Technical Safety Requirements" section of Chapter 3 and those administrative controls that are required per Attachment 1 of DOE Order 5480.22.

5.5.3.1 Contractor Responsibility and Organization. Chapter 11 discusses the organizational structure for ER program and D\&D activities. An administrative control is required to list who is responsible for all actions taken during the activity.

Also, per Chapter 11, lines of authority, responsibility, and communication shall be established and defined for the highest management levels through intermediate levels, to and including all safety and operating organization positions. These relationships shall be documented and updated, as appropriate, in the form of organization charts, functional descriptions of departmental responsibilities and relationships, and job descriptions for key personnel positions, or in equivalent forms of documentation.

5.5.3.2 Procedures. Written procedures shall be established, implemented, and maintained (as a minimum) for the following:

- Facility maintenance procedures for D\&D facilities in standby mode

- Operating procedures

- $\quad$ Procedures governing the administrative aspects of ER program and D\&D activities 
- Abnormal and emergency procedures.

An administrative control is required to ensure that the necessary procedures are generated and that they are properly controlled in accordance with the commitments made in Chapter 17.

5.5.3.3 Programs. The following paragraphs describe the programs that, as a result of this safety analysis, are required to ensure safe operations for ER program and D\&D activities.

5.5.3.3.1 Radiation Protection Program-Procedures for personnel radiation protection shall be prepared consistent with the requirements of the INEL Radiological Control Manual and shall be approved, maintained, and adhered to for operations involving personnel radiation exposure.

5.5.3.3.2 Hazard Evaluation and Elimination Program-Industrial hygiene personnel shall evaluate ER program and D\&D activities and processes to identify and quantify potential health hazards, as required by DOE-Idaho Operations (DOE-ID) Supplemental Directive 5480.10 (DOE-ID 1991), which defines the requirements and procedures for routine hazard evaluations.

5.5.3.3.3 Hazard Communication Program-ER program and D\&D activities shall have a hazard communication program that implements the requirements of 29 CFR 1910.1200, "Hazard Communication." DOE Order 5480.10 details the procedures and responsibilities for implementing this program.

5.5.3.3.4 Hazardous Material Protection Program-The ER program and D\&D activities shall have a hazardous material protection program that will consist of (at a minimum) an Industrial Hygiene Program, as low as reasonably achievable (ALARA) program, and a Medical Monitoring Program. This program applies to acquiring, using, shipping, receiving, and disposing of nonradioactive hazardous materials.

5.5.3.3.5 Quality Program-An administrative control is required to ensure that the quality program discussed in Chapter 14 is prepared and maintained for ER program and D\&D activities. The quality program shall include the requirements of DOE Order 5700.6C, "Quality Assurance," 1991.

5.5.3.3.6 Testing, Inspection, and Preventive Maintenance Program-The testing, inspecting, and preventive maintenance program shall ensure surveillance (preventive maintenance, calibration, testing, etc.) is conducted for $D \& D$ facilities waiting for $D \& D$ activities to begin.

5.5.3.4 Staffing. BSAF does not identify the minimum number of responsible personnel that must be at the activity site for safe operation. This will be established in the activity-specific SAR or Health and Safety Plan.

5.5.3.5 Operating Support. Chapter 17 identifies support personnel who are essential to supporting safe operations at the ER program and D\&D activities. Support functions include, but are not limited to, the areas of waste storage, treatment, and disposal; transportation; fire protection; security; and emergency response. 
5.5.3.6 Qualifications and Training. Staff qualifications and training that ensure safe operations at ER program and D\&D facilities are discussed in Chapter 12. An administrative control is required to ensure that the commitments made in Chapter 12 are implemented and maintained.

5.5.3.7 Reviews and Audits. Reviews and audits are necessary for the safe operation of ER program and D\&D activities. Requirements are necessary to ensure that the following are conducted as appropriate: management assessments, independent review and appraisal of performance, operational readiness reviews, and unreviewed safety question reviews. Those activities that involve common construction equipment and procedures are exempt.

5.5.3.8 Reporting Requirements. The reporting requirements established for ER program and D\&D activities shall be in accordance with DOE Order 5000.3B, "Occurrence Reporting and Processing of Operations," 1993. Reporting requirements are necessary for emergencies, unusual occurrences, and off-normal occurrences.

\subsection{Design Features}

This section should identify and describe the passive design features not specifically required to have TSRs in accordance with the definition in DOE Order 5480.22. This section could simply reference Chapter 2 if that chapter contains the desired information.

\subsection{Interface with TSRs from Other Facilities}

This section should summarize TSRs from other facilities that may affect the specific ER program or D\&D activity's safety basis and briefly summarize the provisions of those TSRs. 


\subsection{References}

Department of Energy, Idaho Operations Office (DOE-ID 1991), Contractor Industrial Hygiene Program, DOE, Washington, DC, DOE 5480.10. 


\section{INADVERTENT CRITICALITY PROTECTION}

\subsection{Introduction}

The U.S. Department of Energy (DOE) Standard DOE-STD-3009-94, Preparation Guide for U.S. Department of Energy Nonreactor Nuclear Facility Safety Anabysis Reports, indicates that this chapter is not applicable to Hazard Category 3 facilities. Chapter 3 of an activity-specific safety analysis shall conservatively demonstrate no potential for a criticality hazard. Facilities that are classified as Hazard Category 3 or are below the Hazard Category 3 threshold do not contain sufficient fissile materials to present a criticality hazard. If a nuclear criticality is possible, based on the fissile material inventory involved with the activity, the activity is classified as Hazard Category 2 in accordance with DOE-STD-1027-92, Hazard Characterization and Accident Analysis Techniques for Compliance with DOE Order 5480.23, Nuclear Safety Analysis Reports. This requires a criticality evaluation per DOE 5480.24, Nuclear Criticality Safety, and is outside the scope of this Baseline Safety Analysis File. The extensive guidance given in DOE-STD-3009-94 is applicable to Category 2 facilities with inventories of fissile materials sufficient to present an inadvertent criticality hazard. 


\section{RADIATION PROTECTION}

The Idaho National Engineering Laboratory (INEL) environmental restoration (ER) program protects personnel and the public from radiation and radioactive materials through a radiological control program administered by the local Radiological Control Organization, as defined in the U.S. Department of Energy Idaho Operations Office (DOE-ID) Radiological Control Manual. It is the policy of Lockheed Idaho Technologies Company (LITCO) to take every precaution to control radiation in the performance of work, to be in full compliance with requirements established by the DOE, to prevent unnecessary radiation exposure to employees and the public, and to prevent harmful effects to the environment. This chapter summarizes the implementation of these policies.

\subsection{Introduction}

The local Radiological Control Organization either integrates radiation protection services from several organizations within the INEL or resides within a facility where ER activities are conducted. Facility or environmental restoration management is responsible for providing a safe work environment and for ensuring that radiation exposure is controlled to as low as reasonably achievable (ALARA) levels. Radiological control technicians (RCTs) evaluate and monitor all radiological conditions, and oversee activities to ensure that all reasonable precautions are taken by personnel.

\subsection{Requirements}

The following Codes of Federal Regulations (CFRs), DOE orders, and other requirements are applicable to this chapter. These requirements are implemented by INEL manuals and procedures as indicated throughout this chapter.

- $\quad 10$ CFR 835, "Radiation Protection Program"

- $\quad 20$ CFR 1910.120, "Hazardous Waste Operations and Emergency Response"

- 29 CFR 1910.134, "General Industry Standards-Respiratory Protection"

- $\quad 49$ CFR 170-180, "Hazardous Materials Tables; Hazardous Materials Communications; Requirements and Emergency Response Information Requirements; Shippers-General Requirement for Shipments and Packaging"

- . ANSI-Z88.2, "Practices for Respiratory Protection," 1980

- $\quad$ ANSI-N323, "Radiation Protection Instrumentation Test and Calibration," 1983

- DOE Order 1324.5B, "Records Management Program," January 12, 1995

- DOE Order 5400.5; "Radiation Protection of the Public and the Environment," February 8, 1990 
- DOE Order 5480.4, "Environmental Protection, Safety, and Health Protection Standards," May 15, 1984

- DOE Order 5480.11, "Radiation Protection for Occupational Workers," December 21, 1988

- DOE Order 5480.15, "Department of Energy Laboratory Accreditation program for Personnel Dosimetry," December 14, 1987

- DOE Order 5484.1, "Environmental Protection, Safety, \& Health Protection Information Reporting Requirements," February 24, 1981

- DOE Order 5820.2A, "Radioactive Waste Management," September 26, 1988

- DOE Order 6430.1A, "General Design Criteria," April 6, 1989

- DOE Radiological Control Manual, DOE/EH-0256T, Rev. 1, April, 1994.

- EPA, FR 87-1716, "Radiation Protection Guidance to Federal Agencies for Occupational Exposure," 1987

- NCRP 65, "Management of Persons Accidentally Contaminated with Radionuclides," 1980.

\subsection{Radiation Protection Program and Organization}

"Radiation Protection for Occupational Workers," 10 CFR 835, contains the primary requirements for occupational radiation protection throughout the DOE Complex. The DOE Radiological Control Manual requires that a site-specific radiological control manual be developed to implement the primary requirements. The INEL Radiological Control Manual describes the radiological control program in detail. Implementing procedures are documented in the LITCO Subject Area Manual (SAM), Radiological Control, and in the EG\&G Company Procedures Manual. The radiological control policy is based on the following principles:

- Personal radiation exposure shall be maintained within ALARA levels

- Radiation exposure of the work force and public shall be controlled such that radiation exposures are well below regulatory limits and that there is no radiation exposure without commensurate benefit

- Each person involved in radiological work is expected to demonstrate responsibility and accountability through an informed, disciplined, and cautious attitude toward radiological hazards 
- Excellent performance is evident when radiation exposures are maintained well below regulatory limits and contamination is minimal, radioactivity is well controlled, and radiological spills and uncontrolled releases are prevented.

The inventory of radioactive materials present will be identified in Chapter 3 of an activityspecific safety analysis report. This information will include types of radioactive materials, maximum quantities, and location. Chapter 9 will identify radioactive wastestream data. Conduct of a specific activity must meet the radiation protection requirements stipulated in the Health and Safety Plan for that specific activity per "Hazardous Waste Operation and Emergency Response," 29 CFR 1910.120.

The Radiological Control Organization ( $\mathrm{RCO}$ ) is an independent organization from line organizational elements responsible for production, operation, and research activities. The RCO reports to the Environment, Safety and Health Division Manager.

The RCO ensures coordination of effort and consistency in implementation of radiological control requirements. A staff of qualified radiological engineers is maintained within the RCO to interpret and ensure the implementation of procedures.

The RCO assigns dedicated, trained, and qualified RCTs and radiological engineering personnel to operational elements, such as environmental remediation and Decontamination and Dismantlement (D\&D) projects. These radiological control personnel receive their day-to-day priorities from project line management, but report administratively and are accountable to the RCO manager.

\subsection{ALARA program and Policy}

Guidance to Federal agencies directs that there should be no occupational exposure of workers to ionizing radiation without the expectation of an overall benefit from the activity causing the exposure (EPA 1987). Therefore, radiation exposure of the work force and public is controlled to assure that radiation exposures are below regulatory limits and ALARA. The INEL Radiological Control Manual provides the requirements for the ALARA policy and program. LITCO is committed to reducing any safety or health risks associated with hazardous substances (including ionizing radiation) to ALARA levels by promoting ALARA policy awareness, and reducing and keeping radiation exposures to ALARA levels. The following methods are used to achieve ALARA objectives:

- Establishing employee- and organizational-level ALARA goals, tracking employee exposure, and maintaining associated records

- Allocating the appropriate technical, administrative, and supervisory resources that are necessary

- Appointing an ALARA coordinator to oversee and evaluate efforts, and providing technical assistance for identifying needed improvements 
- Restricting access to radiation and contamination areas

- Using equipment mockups, cell photos, videotapes, etc., to minimize the working time required in high radiation areas and high surface contamination areas, as appropriate

- Using engineered controls (e.g., ventilation, remote handling, and shielding) and monitoring equipment (e.g., continuous air monitors and remote area monitors).

\subsection{Radiological Protection Training}

The INEL radiation safety training program ensures that personnel have the training to work safely in and around radiological areas and to maintain individual radiation exposure and the radiation exposures of other individuals at ALARA standards. Training requirements are described in Chapter 12. All individuals requiring access to radiological-controlled areas at the INEL receive training that emphasizes the nature of radiological conditions and the control of radiation exposure. The INEL Radiological Control Manual provides instructions for determining the training requirements, based on activities and responsibilities of the INEL workers. Upon completion of this training, training certification cards are issued for facility access. The type of certification is based on the type of training received and the type of access required.

Level of training for RCTs are commensurate with the technician's assignment. Qualifications for RCTs consist of standardized course material, on-the-job training, and passing both a comprehensive written examination and final Oral Examination Board. The level of RCT qualification is based on the education, experience, training, orientation, and other qualifications achieved and maintained by the individual. RCTs qualifications follow a two-year cycle of continuing training evaluated with a written and oral examination.

Training is also provided for other radiological support personnel; who provide health physics and radiological engineering, dosimetry, bioassay, independent oversight, and instrumentation calibration functions; to ensure these personnel have the technical qualifications pertinent to their assigned duties. The RCO senior staff consists of health physicists and other professionals with four-year degrees in science or engineering.

\subsection{Radiation Exposure Control}

The INEL Radiological Control Manual describes practices for controlling exposures, including radiation surveillance, permanent and temporary shielding, exposure monitoring, and access control to radiation areas. Facility or project management specifies the responsibilities and requirements necessary to ensure that employee and visitor exposure to external radiation sources is ALARA and, in all cases, within DOE requirements. Detailed exposure records are generated and maintained on all exposed individuals, and are used as a basis for identifying individuals who may potentially approach or exceed allowable limits.

Internal radiation exposure is controlled in accordance with the INEL Radiological Control Manual, which provides requirements to prevent and minimize internal radiation exposure. A 
documented internal dosimetry and control plan is maintained that describes the practices and procedures that constitute the internal dose program.

The potential primary sources of radiation during ER activities at INEL result from the following:

- Source materials (uranium, for example) and processes used in the support of national defense and energy programs

- Wastes generated from these defense and energy programs

- Contaminated equipment

- Past spill cleanup and waste storage, treatment, and disposal activities.

Types of radionuclides at ER sites include the following:

- Alpha emitters, chiefly transuranic materials from reactor operations and chemical separation and recovery, such as americium $\left({ }^{241} \mathrm{Am}\right)$

- Beta-gamma emitters, chiefly fission and activation products due to reactor operations and chemical separation operations, such as cesium $\left({ }^{137} \mathrm{Cs}\right)$ and cobalt $\left({ }^{60} \mathrm{Co}\right)$

- Pure beta emitters, primarily the fission product strontium $\left({ }^{90} \mathrm{Sr}\right)$.

ER soil sampling, drilling, treatment, and earthmoving activities result in gamma radiation exposure through exposure to contaminated soils, liquids, and sludges. D\&D activities result in gamma radiation exposure from contaminated surfaces and residual contamination in tanks and systems.

Gamma exposure will be controlled through minimizing time spent in radiation areas, maximizing distance to contaminated materials, and shielding provided by existing structures or soil layers. Additional temporary shielding may be added as appropriate and optimal under the ALARA evaluation process.

ER earthmoving and drilling activities will generate airborne radioactive materials. Surface decontamination, grinding, cutting, and other $\mathrm{D} \& \mathrm{D}$ activities will generate airborne radioactive material. Inhalation of these materials is the primary source of internal exposure to ER personnel. Ingestion or injection of radioactive material into the body is not expected to be a significant source of internal exposure. The beta emitter, ${ }^{90} \mathrm{Sr}$, and alpha emitter, ${ }^{241} \mathrm{Am}$, are chief concerns for internal exposure from uptakes of contaminated dusts from soils. Contaminated sludges, if suspended in air, may result in additional uptakes of curium $\left({ }^{244} \mathrm{Cm}\right)$ and cerium $\left({ }^{144} \mathrm{Ce}\right)$.

Radiation protection personnel evaluate each activity for application of engineering controls to reduce airborne contamination at the source. Many ER activities may involve extensive earthmoving or D\&D tasks, which may render engineering control impractical or less effective. In 
these cases, respiratory protection will reduce or eliminate internal exposure. Internal exposures are expected to be ALARA and well below $100 \mathrm{mrem} / \mathrm{yr}$ committed effective dose equivalent.

ER Program personnel will handle materials with removable contamination and enter contaminated areas. Beta-gamma emitting radionuclides, ${ }^{137} \mathrm{Cs}$ and ${ }^{60} \mathrm{Co}$, are of greatest concern for skin contamination. Procedures for control of contamination, and for maintaining, selecting, donning, and removing protective clothing provide protection against contamination of the skin.

\subsubsection{Administrative Limits}

The INEL Radiological Control Manual itemizes administrative controls. The objective is to maintain personnel radiation exposure well below regulatory dose limits. To accomplish this objective, challenging numerical administrative control levels are established at levels below the regulatory limits to administratively control and help reduce individual and collective radiation dose. These control levels are multi-tiered, and increasing levels of authority are required to approve higher administrative control levels. The administrative control levels for radiation exposure are listed in Table 7-1 per DOE.

Special control levels are established with the assistance of the radiological health advisory group as described in the INEL Radiological Control Manual. Exposure limits in area emergency plans are governed by the INEL Radiological Control Manual and 10 CFR 835 subpart N.

\subsubsection{Radiological Practices}

Based on survey results, radiological areas are determined and their boundaries are marked and posted by RCTs in accordance with the LITCO SAM, Radiological Control, EG\&G Idaho Company Procedures Manual, and INEL Radiological Control Manual. Work is controlled by radiological work permits and other approved radiological work procedures, keeping individual and collective exposures within ALARA guidelines.

The radiological practices used to control exposure to radiological hazards are discussed in the EG\&G Idaho Company Procedures Manual, the LITCO Radiological Control SAMs and INEL Radiological Control Manual. These practices address precautions required to conduct radiological tasks, such as special personnel protective equipment and permanent or temporary shielding. In general, radiological practices used to control exposure include posting radiological areas, controlling activities within the radiological areas, and ensuring entry and exit control.

7.6.2.1 Posting Areas. DOE approved signs, labels, and radiation symbols are conspicuously posted for radiological controlled areas as required by the INEL Radiological Control Manual. Each access point to a controlled area is posted. The size of the areas is determined using the guidelines in the INEL Radiological Control Manual. The rope, tape, chain, or similar barrier used to control access are to be yellow and magenta in color. The alteration or removal of control barriers is performed by, or under the direction of, RCTs.

7.6.2.2 Radiological Work Permits. The radiological work permit (RWP) is an administrative mechanism used to establish radiological controls for intended work activities. The RWP informs workers of area radiological condition and entry requirements and provides a 
mechanism to relate worker exposure to specific work activities. A RWP contains pertinent information for performing the intended work safely and within ALARA guidelines. The information includes but is not limited to a description of the work, radiological conditions of the work area, dosimetry requirements, stay time controls, and special dose or contamination reduction considerations.

RWPs are required to enter radiation, high radiation, and very high radiation areas; contamination and high contamination areas; and airborne radioactivity areas. Job-specific RWPs are used for nonroutine operations or work in areas with changing radiological conditions. Job-specific RWPs remain in effect only for the duration of the job. General RWPs are used for routine or repetitive activities, such as tours and inspections or minor work activities, in areas with well-characterized and stable radiological condition. General RWPs can be approved for periods up to one year.

The RWP is approved by the supervisor responsible for the work area and the appropriate radiological control supervisor. Racliological surveys are reviewed to evaluate adequacy of the RWP requirements. Workers acknowledge that they have read, understand and will comply with the RWP prior to initial entry to the area and after any revisions to the RWP.

7.6.2.3 Entry and Exit Control. Personnel entry control is maintained for each radiological area per the INEL Radiological Control Manual. The degree of control is commensurate with existing and potential radiological hazards within the area. One or more of the following methods are used to ensure control: posting, control devices on entrances, conspicuous visual and audible alarms, locked entrance ways, or administrative controls.

Table 7-1. Values for radiation exposure.

\begin{tabular}{|c|c|c|}
\hline Person & Type of exposure & Annual limit \\
\hline Radiological worker & $\begin{array}{l}\text { Whole body (internal and } \\
\text { external) }\end{array}$ & $5 \mathrm{rem}^{\mathrm{a}, \mathrm{b}}$ \\
\hline Radiological worker & Lens of eye & 15 rem \\
\hline Radiological worker & Extremity & 50 rem \\
\hline Radiological worker & $\begin{array}{l}\text { Any organ or tissue (other } \\
\text { than lens of eye) and skin }\end{array}$ & $50 \mathrm{rem}^{\mathrm{c}, \mathrm{d}}$ \\
\hline Declared pregnant worker & Embryo/fetus & $0.5 \mathrm{rem}$ in $9 \mathrm{mo}$ \\
\hline $\begin{array}{l}\text { Minors and students (under } \\
\text { age 18) }\end{array}$ & Whole body & $0.1 \mathrm{rem}$ \\
\hline Visitors and public & Whole body & 0.1 rem \\
\hline
\end{tabular}




\subsubsection{Dosimetry}

7.6.3.1 External Dosimetry. The INEL Radiological Control Manual, LITCO SAM, Radiological Control, and EG\&G Idaho Company Procedures Manual establish the policy, requirements, and training necessary for assignment and use of external dosimetry. External dosimetry devices used for monitoring occupational whole body exposure are accredited by the DOE Laboratory Accreditation program for the appropriate radiation types and categories.

External dosimetry provides indication of the radiation exposures received by personnel, equipment, and the environment. Personnel wear external dosimetry that is capable of indicating both penetrating and nonpenetrating radiation exposure that contributes to a person's occupational exposure. The INEL area/environmental monitoring program provides exposure information on areas internal and external to the INEL. All external dosimetry used at the INEL is analyzed by Radiological Control, Radiation Dosimetry and Records (RDR).

7.6.3.2 Internal Dosimetry. Employees are categorized by job tasks and exposure potential. Those that may exceed the INEL Radiological Control Manual bioassay trigger level are included in the bioassay program. As a minimum, all employees who are likely to receive intakes resulting in an effective dose equivalent greater than $100 \mathrm{mrem}$ undergo initial, periodic, and termination baseline whole-body counts or bioassays.

A radiological engineer assesses the radiation dose received from internally deposited radioactive materials on the basis of any bioassay results (whole-body count or biological samples). Concurrence with the results and methodology is required. If the assessment indicates a dose greater than $10 \mathrm{mrem}$ total committed effective dose equivalent, the assessment is documented and submitted to the RDR, which manages the bioassay program and maintains a summary of the dose equivalents received from external and internal sources.

\subsubsection{Respiratory Protection}

The EG\&G Idaho Company Procedures Manual provides guidelines for selecting respiratory equipment for protection against airborne radioactivity. These procedures incorporate the requirements of American National Standards Institute (ANSI) Z88.2, "Practices for Respiratory Protection" (ANSI 1992). Respirators for radiological exposure control are used in accordance with the INEL Radiological Control Manual.

\subsection{Radiological Monitoring}

Radiological monitoring and contamination control are maintained to ensure that radiation exposure and contamination limits contained in the INEL Radiological Control Manual are not exceeded. The radiological monitoring and contamination control program consists of monitoring radiation exposure levels, contamination levels, and airborne radioactivity levels according to the EG\&G Idaho Company Procedures Manual.

Engineered controls and work practices are implemented to minimize and control the spread of contamination. Contamination of work surfaces is maintained at the lowest level practicable. 
Radiological materials are packaged so that loose surface contamination is contained and outer surfaces fall below DOE acceptable levels for removable contamination and total (fixed plus removable) contamination levels.

External monitoring of personnel for beta/gamma- or alpha-emitting contamination is required before personnel can exit a contamination area, high contamination area, or radiological buffer area established for contamination control purposes. Only personnel trained as radiological workers are permitted to monitor (frisk) themselves. The cause of contamination on personnel is evaluated and reported to management. If required, an occurrence report is issued in accordance with the EG\&G Idaho Safety Manuial.

The air monitoring program is set up to (a) measure the amount of airborne radioactive material, (b) establish the necessary protective measures for the workforce, (c) trend the airborne concentration to control workplace airborne radioactivity exposures, and (d) support the bioassay program. Monitoring of airborne radioactivity is performed in accordance with the INEL Radiological Control Manual.

Representative ambient air samples are taken in strategic locations (determined using hazard index calculations and facility air flow studies) to detect and evaluate airborne radioactivity at work locations. Portable air samples or lapel samplers are used to provide information on breathing zone conditions. Continuous air monitors are used for area monitoring to determine general area conditions. Air sample information and lapel sample information are logged in the RCT daily logbook. Constant air information is logged in separate logbooks.

\subsection{Radiological Protection Instrumentation}

The EG\&G Company Procedures Manual and the LITCO SAM Radiological Control establish the standards and practices for calibration and control of radiological instrumentation. Properly selected, operated, maintained, and calibrated radiological instrumentation is employed in order to implement an effective radiological control program. Typical instruments used include:

- Continuous air monitors, which are located in areas with the potential for airborne contamination. The potential for airborne contamination is based on hazard index calculations. Alpha and beta-gamma sensitive detectors monitor for levels of airborne radioactivity.

- Remote area monitors, which indicate the radiation level and alarm at predetermined levels in accordance with the INEL Radiological Control Manual

- Personnel contamination monitors, which are used to monitor for external contamination on personnel entering and leaving Radiological Buffer Areas and contamination areas

- Portable alpha detectors, which are used for field survey of surface and personnel contamination 
- A variety of portable alpha and beta-gamma detectors and suitable rate meters, which are used for both surface and contamination monitoring

- Low-background alpha-beta counters, which indicate the level of contamination on smears and air filters.

The INEL Radiological Control Manual and LITCO SAM Radiological Control provide requirements for the calibration, response check, operational inspection, maintenance, and repair of standard radiological instruments. These procedures are applicable to fixed and portable instruments.

\subsection{Radiological Protection Recordkeeping}

Radiation protection records are retained to document the effectiveness of the radiation protection program and demonstrate compliance with DOE 1324.5B, DOE 5484.1B (DOE 1981), DOE 5480.11 (DOE 1988a), and the INEL Radiological Control Manual. Radiological protection records specify requirements for occupational exposure records and those records used for dose reconstruction. The EG\&G Idaho Company Procedures Manual and INEL Radiological Control Manual provide direction on the development, management, and retention of records. Records that document the appropriateness, quality, and accuracy of methods, techniques, and procedures in use during any given period are maintained in accordance with ANSI N-13.6, "Practice for Occupational Radiation Exposure Records System" (ANSI 1966).

Tracking of exposures for workers is conducted in accordance with the INEL Radiological Control Manual. Dosimetry reports prepared by the RDR show organizational dose totals. In addition, individual employee dose totals and ALARA goals are listed, and the names of employees who are projected to exceed, or who have exceeded, their ALARA goal are flagged.

Individual occupational internal dose records used to assess individual doses are maintained to provide appropriate reports to the employee and management. Also, reports are generated as required by DOE Orders 5484.1 and $1324.5 B$. Records are readily available for all current employees.

Active employees are provided an annual report of their dose. Terminated employees receive a report at termination. Monitoring results, including zero dose, are reported to each visitor within 30 days. Upon request, any individual may receive a current radiation dose record. Detailed information concerning any individual's exposure are available upon request by the individual, consistent with the provisions of the Privacy Act.

Official records of the INEL radiation dose are retained by the INEL Radiation Dosimetry program. Individual dose records are normally retained for 75 years, and will be retained as directed to support epidemiological studies. Records retained and reported are sufficient to support recalculation of doses at a later date. 


\subsection{Occupational Radiation Exposures}

Radiation exposure guidelines are based on DOE requirements and apply to occupational radiation exposure, which excludes radiation exposure from medical, dental, and natural background sources. This section will summarize the predicted annual exposures to workers from radiation sources. This information shall be based on historical facility radiation data or, for new operations, on estimates of the average and maximum operating conditions, inventories, personnel occupancy factors, etc. Estimated exposures can be based on historical data for similar facilities. An explanation of the methods and assumptions used shall be provided. Also, a comparison with maximum allowable limits shall be given and any discrepancies discussed. 


\subsection{References}

American National Standards Institute (ANSI 1992), "Practices for Respiratory Protection," ANSI-Z88.2-1991, May 19.

American National Standards Institute (ANSI 1966), "Practice for Occupational Radiation Exposure Records Systems," ANSI N-13.6, 1966.

Environmental Protection Agency (EPA 1987), "Radiation Protection Guidance to Federal Agencies for Occupational Exposure," signed by President Reagan, January 20, 1987, EPA, U.S. Government Printing Office, Washington, D.C., FR 87-1716. 


\section{HAZARDOUS MATERIAL PROTECTION}

This chapter addresses nonradioactive hazardous material protection provisions for workers and the public (see Chapter 7 for radioactive protection provisions). Application of the graded approach for this chapter is dependent on the type and magnitude of the hazards identified in the hazard analysis (Chapter 3).

\subsection{Introduction}

Programs at the Idaho National Engineering Laboratory (INEL) protect personnel and the public from hazardous materials through implementation of industrial hygiene, industrial safety, and construction safety programs. The primary requirements for occupational health and safety programs are found in U.S. Department of Energy (DOE) Directives, Occupational Safety and Health Administration (OSHA) Standards, and other applicable guidance specified in DOE Order 5480.4, "Environmental Protection, Safety, and Health Protection Standards."

DOE 5480.4 specifies mandatory environmental protection, safety, and health (ESH) standards and lists reference ESH standards. These standards cover the following categories: emergency preparedness, environmental protection, fire protection, occupational health protection, occupational safety, nuclear safety, and transportation safety.

DOE 5480.4 requires compliarce with OSHA 29 CFR 1910, "Occupational Safety and Health Standards." With respect to hazardous material protection, the OSHA standard provides regulations for exposures to carcinogens and other hazardous chemicals. OSHA regulation 29 CFR 1910.120(b)(4) requires that site-specific health and safety plans be written to address safety and health hazards of each phase of the hazardous waste site operation and includes procedures for employee protection.

DOE Idaho Operations Office (DOE-ID) contractors must develop and implement an industrial hygiene program for employees that complies with DOE 5480.10, Contractor Industrial Hygiene Program. A control program for hazardous material is outlined in the EG\&G Idaho Industrial Hygiene Manual and Company Procedures Manual as adopted by Lockheed Idaho Technologies Company (LITCO). The program applies to acquiring, using, shipping, receiving, storing, and disposing of hazardous materials. The program complies with the Toxic Substances Control Act, Superfund Amendments and Reauthorization Act, Occupational Safety and Health Act, Comprehensive Environmental Response, Compensation, and Liability Act, and requirements listed in Section 8.2.

The inventory of hazardous materials at an activity's work site will be identified in Chapter 3 of activity-specific safety analysis documentation. Chapter 9 will identify hazardous material waste stream data. Recognition, evaluation, and control of health and safety effects on the public or workers associated with these hazardous materials is the subject of this chapter. 


\subsection{Requirements}

The following Codes of Federal Regulations, DOE orders, and other requirements are applicable to this chapter. These requirements are implemented by LITCO via its adoption of the EG\&G Idaho manuals and procedures as indicated throughout the chapter.

- 29 CFR 1910, "Occupational Safety and Health Standards"

- $\quad 40$ CFR 355, "Emergency Planning and Notification"

- DOE Order 1324.5B, "Records Management Program," September 13, 1988

- DOE Order 5480.4, "Environmental Protection, Safety, \& Health Protection Standards," May 15, 1984

- DOE Order 5480.8A, "Contractor Occupational Medical Program," July 26, 1992

- DOE Order 5480.10, "Contractor Industrial Hygiene Program," June 26, 1985.

\subsection{Hazardous Material Protection and Organization}

LITCO maintains a hazardous material protection program to provide a workplace free of occupational health hazards. To support this program, an industrial hygienist from the Engineering and Project Management Department within the Environment, Safety and Health Division will be assigned to an environmental remediation project.

The industrial hygiene program identifies, evaluates, and controls potential health hazards arising from chemical, biological, and physical agents (excluding ionizing radiation) in the workplace. The program goal is to achieve a workplace free from hazards that may cause illness, serious physical harm, or death. The industrial hygiene program is detailed in the EG\&G Idaho Industrial Hygiene Manual.

\subsection{ALARA Policy and Program}

The goal of hazardous material protection is to ensure that employee exposures to hazardous materials are as low as reasonably achievable (ALARA). This goal is achieved through the industrial hygiene program using the following controls:

- Approved and controlled procedures provide administrative and engineering controls to minimize or eliminate exposure to hazardous materials

- Appropriate personal protective equipment is used, in accordance with DOE-ID Appendix 0550 and 29 CFR 1910 
- Employees are trained to recognize potential hazards, take safety precautions, understand the consequences of an accident, and know the actions to take in case of an accident

- The work environment is monitored to obtain personnel and area exposure data

- In an effort to minimize the use of hazardous materials, industrial hygienists review purchase requisitions for products that contain or that may result in the production of hazardous chemicals, and provide an overview of chemical usage. This review process allows substitution of less hazardous materials and ensures that the necessary controls are implemented to maintain personnel exposures at ALARA levels.

\subsection{Hazardous Material Training}

Training requirements are described in Chapter 12. Training plans are prepared for personnel and are updated periodically to reflect current requirements. All personnel are trained to the level necessary to perform their jobs. This training identifies the hazards associated with an activity and emphasizes the employee's responsibility to stop before taking a particular step in an activity if the employee lacks understanding or comfort with the outcome of the act. All personnel are trained to stop any activity that is felt may endanger the worker, the environment, or the public.

Procedures that govern operations involving hazardous materials have been developed in the EG\&G Idaho Company Procedures Manual, Safety Manual, and Industrial Hygiene Manual. Specific procedures for each activity will be outlined or referenced in the Health and Safety Plan. With the exception of routine activities (such as janitorial, administrative, and yard work), work is performed by trained employees operating in accordance with reviewed and approved procedures. Chapter 12 explains how work control procedures are used to control work.

\subsection{Hazardous Material Exposure Control}

This section summarizes the plans and procedures for controlling occupational exposure to contamination and spread of hazardous materials.

\subsubsection{Hazardous Material Identification Program}

The industrial hygiene program evaluates operations and processes to identify and quantify potential health hazards, as required by DOE Order 5480.10. The EG\&G Idaho Company Procedures Manual, Section 11.9, "Industrial Hygiene Workplace Surveys," defines the requirements and procedures for routine hazard evaluations. The industrial hygiene evaluation also recommends engineering control measures, process changes, or substitution of less toxic materials to minimize or eliminate exposure to hazards. Administrative controls and personal protective equipment are used to supplement engineering controls.

An industrial hygienist reviews and approves all applicable work control documents and purchase requisitions for products that contain or that may result in operational exposure to 
hazardous chemicals. The industrial hygienist also evaluates the extent or degree of hazard. The review considers employee health risk, effectiveness of controls, special regulatory requirements, and additional employee training requirements. The EG\&G Idaho Company Procedures Manual, Section 11.2, "Hazard Communication," specifies the justification, review, and approval of hazardous material procurements.

The carcinogen control program, based on the requirements of DOE Order 5480.10, provides instructions for controlling occupational exposures to chemical carcinogens. The EG\&G Idaho Company Procedures Manual, Section 11.6, "Carcinogen Control," defines this program and establishes the criteria used to eliminate the use of carcinogens, prevent exposures, and provide a wide margin of safety for operations where carcinogens are used.

Chemicals covered by this program include all carcinogens regulated by OSHA standard 29 CFR 1910, Subpart Z, and those listed as carcinogens and suspect carcinogens in Appendix A of the American Conference of Governmental Industrial Hygienists threshold limit value booklet (ACGIH 1993). The program governs all operations where industrial hygiene has determined that the use of a carcinogen creates a significant potential for exposure. Principal elements of this program include the following:

- Review and approval of purchase requisitions for carcinogenic chemicals or products by the industrial hygienist. Approval is granted only in those instances where it is impossible to substitute a less hazardous product. Justification from the requesting manager must accompany all purchase requisitions for carcinogenic chemicals or products.

- Industrial hygiene evaluations of personnel and workplace exposure levels.

- Implementation of control measures to eliminate or reduce exposures to ALARA levels.

- Written standard operating procedures describing the use of a chemical carcinogen and the procedures used to control exposure.

- Employee awareness of chemical carcinogens by establishing regulated areas, labeling all containers, and completing job-specific training for all personnel working with chemical carcinogens.

\subsubsection{Administrative Limits}

The administrative control levels and exposure limits are those adhered to by LITCO. These control levels and exposure limits are itemized in the EG\&G Idaho Industrial Hygiene Manual and Company Procedures Manual.

\subsubsection{Occupational Medical Programs}

The LITCO Occupational Medicine Department (OMD), as required by DOE Order 5480.8A, provides medical treatment and assessment of employees who are exposed to 
hazardous agents. The medical monitoring program is defined in the EG\&G Idaho Industrial Hygiene Manual, Section 8, "Occupational Medical Program Content," and the EG\&G Idaho Safety Manual, Section 4, "Medical and First Aid."

The industrial hygiene program records hazard exposure data for employees. The OMD uses these data to assess potential exposures and adverse health effects attributed to occupational stresses, and to support appropriate investigations relating to exposures. The OMD is responsible for the following:

- Developing medical surveillance guidelines for chemical and physical agents that do not have legally specified requirements

- Conducting periodic walkthrough surveys of the workplace

- Conducting preplacement assessments for employees working in areas where respirators are required or where exposure to hazardous agents is likely

- Establishing (in consultation and cooperation with industrial hygiene personnel) biological monitoring protocol, as deemed necessary for specific exposures

- Maintaining medical history and employee exposure records of all biological monitoring results.

\subsubsection{Respiratory Protection Program}

All personnel who use respiratory equipment are formally trained and qualified before using any respiratory equipment. The EGi\&G Idaho Company Procedures Manual, Section 11.1, "Respiratory Protection Program Procedures," provides guidelines for selecting respiratory equipment. This procedure incorporates the requirements of American National Standards Institute Z88.2-1991, "Practices for Respiratory Protection."

All equipment is approved by the National Institute of Occupational Safety and Health and the Mine Safety and Health Administration. This equipment includes the following:

- $\quad$ Air-purifying, full-face respirators

- Pressure-demand, self-contained breathing apparatus

- Air-purifying, half-face respirators

- Airline bubble hoods (single-use only) evaluated by Los Alamos National Laboratory and accepted by DOE. 


\subsection{Hazardous Material Monitoring}

Airborne exposure levels for nonradiological contaminants are determined from area and personnel monitoring. The EG\&G Idaho Company Procedures Manual, Section 11.5, "Industrial Hygiene Air Contaminant Sampling," contains the implementing procedure.

Industrial hygiene personnel monitor for exposures resulting from all processes or work operations that could produce hazardous air contaminants. The monitoring instruments, sampling devices, and procedures used have a known, demonstrated accuracy.

Workplaces and operations are surveyed to identify both potential and existing health hazards, and to evaluate them according to approved procedures and as required by DOE Order 5480.10. Section 11.9 of the EG\&G Idaho Company Procedures Manual provides instructions for conducting routine workplace surveys.

These surveys identify and quantify potential health hazards, and verify the efficacy of implemented controls. Hazards surveyed include chemical, physical (excluding ionizing radiation), biological, and ergonomic hazards. Once the degree of hazard has been assessed, appropriate control measures are recommended and implemented. Workplaces are periodically evaluated to ascertain the efficiency of implemented controls and to ensure that new hazards have not arisen.

\subsection{Hazardous Material Protection Instrumentation}

Industrial hygienists use methods available, either by laboratory analysis or instrument monitoring, to effectively monitor chemical and physical agents that could pose a health risk. Workplace hazards requiring the use of monitoring instruments include, but are not limited to, noise, heat stress, toxic fumes, dusts, gases and vapors, and oxygen-deficient and flammable atmospheres. Instrumentation is also provided to evaluate the effectiveness of engineering controls. Only an industrial hygienist, or a trained technician under the supervision of an industrial hygienist, may perform instrument operations.

Monitoring activities are conducted using instruments or sampling devices that have been appropriately calibrated and maintained to ensure accurate and reproducible results. Calibration standards are traceable to the National Institute of Standards and Technology. The EG\&G Idaho Company Procedures Manual, Section 11.4, "Calibration and Monitoring Maintenance Program for Industrial Hygiene Instrumentation," specifies the frequency and method of calibration.

Records of all instrument calibration activities are maintained in a calibration logbook. Calibration labels are placed on all monitoring equipment, indicating the date on which calibration is due. Each instrument is visually examined for defects, current calibration dates, and battery conditions. If necessary, it is field calibrated before each use. Instruments that are not maintained in an operational state or that are found to be defective are tagged out of service to prevent inadvertent use, and are segregated until properly disposed of, repaired, or calibrated. 


\subsection{Hazardous Material Protection Recordkeeping}

Recordkeeping and documentation are important support elements of the industrial hygiene program. Records are maintained in accordance with DOE Order 1324.5B to document the existence of potential hazards and the degree of hazards encountered in the facility and operations. The EG\&G Idaho Company Procedures Manual, Section 11.14, "Management of Industrial Hygiene Monitoring Records," details the maintenance and disposition of monitoring and sampling records.

All monitoring data are maintained on industrial hygiene monitoring data forms, which provide input into an industrial hygiene data base. The OMD maintains a medical record of biological monitoring results that directly assesses exposure to toxic substances for each employee. All employee exposure records are maintained for 75 years, protecting the legal interests of both the employee and INEL contractors.

\subsection{Hazard Communication Program}

The hazard communication program institutes all requirements of 29 CFR 1910.1200 and DOE Order 5480.10 by informing all employees about the potential hazards associated with chemical, physical, and biological agents in their workplace. The EG\&G Idaho Industrial Hygiene Manual, Section 6, "Hazard Communication," adopts the requirements of OSHA's expanded hazard communication program. Section 11.2 of the EG\&G Idaho Company Procedures Manual details the procedures and responsibilities for implementing these requirements.

The hazards of all chemicals, imported or produced, are evaluated by industrial hygiene personnel. Such chemical information is transmitted to employers and employees through the hazard communication program. The hazard communication process includes provisions for inventorying hazardous agents, labeling containers, supplying material safety data sheets for hazardous materials, and training eraployees about workplace hazards.

\subsection{Occupational Chemical Exposures}

This section will summarize the predicted annual exposures to workers from hazardous material sources. This information shall be based on historical facility data or, for new operations, on estimates of the average and maximum operating conditions, inventories, personnel occupancy factors, etc. Estimated exposures can be based on historical data for similar facilities. An explanation shall be provided of the methods and assumptions used. Also, a comparison with maximum allowable limits shall be given and any discrepancies discussed. 


\subsection{References}

American Conference of Governmental Industrial Hygienists (ACGIH 1993), 1993-1994 Threshold Limit Values for Chemical Substances and Physical Agents and Biological Exposure Indices, ISBN: 1-882417-03-8, Cincinnati, OH.

American National Standards Institute, (ANSI 1992), "Practices for Respiratory Protection," ANSI

Z-88.2-1991, May 19. 


\section{RADIOACTIVE AND HAZARDOUS MATERIAL WASTE MANAGEMENT}

This chapter describes the quantities, sources, forms, and characteristics of radioactive waste, hazardous waste, and mixed waste (both radioactive and hazardous) generated during environmental restoration activities. The capabilities to control, handle, process, store, and transport the waste within regulatory guidelines are assessed. The instrumentation used to monitor releases and the administrative and operational controls important to the effective management of the waste are considered in this assessment.

\subsection{Introduction}

Environmental restoration (ER) at the Idaho National Engineering Laboratory (INEL) that includes environmental remediation and Decontamination and Dismantlement (D\&D) activities will generate radioactive, hazardous, mixed, and nonhazardous waste streams. Protection of the public, workers, and the environment are integral factors in the management of these waste streams. The generation, treatment, storage, transportation, and/or disposal of waste materials will be accomplished in a manner that minimizes such wastes and complies with applicable Federal and state environmental, safety, and health laws and regulations and U.S. Department of Energy (DOE) requirements. The objectives of the INEL waste management program are to ensure compliance with applicable guidelines and regulatory requirements, conserve resources, and eliminate or generate a minimum of waste and pollution.

The ER program waste management options include the following activities, which may occur in parallel:

- Removal of waste and reuse of all recyclable materials

- Minimization of additional waste generation during cleanup activities by control of emissions to air and water:

- Remediation of waste in place

- Treatment, storage, and disposal (TSD) of waste at onsite facilities

- Treatment and storage of waste at onsite facilities and disposal at offsite facilities

- Treatment and disposal of waste at offsite facilities.

The following sections describe the framework for radioactive and hazardous material waste management. Detailed discussion of. individual waste management practices will be described in the specific safety analysis documentation for each ER activity. 


\subsection{Requirements}

The following Codes of Federal Regulations (CFRs), DOE orders, and other requirements are applicable to this chapter. These requirements are implemented by Lockheed Idaho Technologies Company (LITCO) via its adoption of the EG\&G Idaho Safety Manual and Company Procedures Manual, and by the INEL Radiological Control Manual.

- 40 CFR 260, "Hazardous Waste Management System: General"

- 40 CFR 261, "Hazardous Waste Management System: Identification and Listing of Hazardous Wastes"

- 40 CFR 262, "Standards for Generators of Hazardous Wastes"

- 40 CFR 263, "Standards for Transporters of Hazardous Wastes"

- 40 CFR 264, "Standards for Owners and Operations of Hazardous Waste Treatment, Storage, and Disposal Facilities"

- 40 CFR 265, "Interim Status Standards for Owners and Operators of Hazardous Waste Treatment, Storage, and Disposal Facilities"

- 49 CFR 171, "Hazardous Materials Regulations, General Information, Regulations, and Definitions"

- 49 CFR 173, "Shippers-General Requirements for Shipments and Packagings"

- $\quad$ DOE Order 5400.1, "General Environmental Protection Program," November 9, 1988

- $\quad$ DOE Order 5820.2A, "Radioactive Waste Management," September 26, 1988

- Title I, Idaho Department of Health and Welfare Rules and Regulations, "Environment," Chapters 1, 2, 8, and 16.

\subsection{Radioactive and Hazardous Waste Management Program and Organization}

NNEL and EG\&G Idaho manuals, as adopted by LITCO, establish the responsibility of managers for overseeing all waste (including solid, liquid, and airborne) management to minimize health hazards, public nuisances, or pollution of the environment, and to comply with the requirements listed in Section 9.2. The ER manager ensures that (a) a waste management program is in place, (b) a spill or Resource Conservation and Recovery Act contingency plan is established for handling unplanned spills of regulated waste, (c) emergency action plans are established for handling all unplanned releases involving radioactive, hazardous, or mixed waste, and (d) all personnel are trained in the correct and safe disposal of radioactive, hazardous, and mixed waste. 
Hazardous, radioactive, mixed, and nonhazardous wastes generated by ER activities will be treated, stored, and disposed of in facilities located on the INEL and offsite. Waste acceptance criteria for all INEL facilities are contained in Idaho National Engineering Laboratory Reusable Property, Recyclable Materials, and Waste Acceptance Criteria (RRWAC) (DOE-ID 1995a). The RRWAC applies to reusable property (other than materials to be exchanged), materials to be exchanged, recyclable materials, nonradioactive waste, and radioactive waste. The RRWAC requires that first consideration always to be given to reuse of property in its original form, then to recycling of any pieces of the property, and finally to separation of the waste material such that it can be treated, stored, and disposed of in the most effective and efficient manner. The policy of the DOE Idaho Operations Office (DOE-ID), as stated in the RRWAC, is to ensure compliance with the following:

- The first priority of DOE and the primary responsibility of the generator is to prevent the generation of waste and minimize the volume and hazard of such material at the source

- Reusable property, recyclable materials, and waste are managed on a systematic basis, satisfying the requirements of applicable DOE orders and Federal and state regulations

- All operations are managed in a manner that protects the health and safety of the public and workers, and preserves the environment of the INEL

- Special authorization must be obtained before shipping any materials or packages that do not meet the criteria stated in the RRWAC

- Requests from non-INEL generators to transport recyclable materials and waste to appropriate INEL receiving facilities will be considered by DOE-ID

- Recyclable materials and waste, other than office waste, will not be received by DOEID receiving facilities from INEL generators that do not have an auditable waste minimization program in effect.

The INEL waste minimization program has been developed pursuant to DOE Orders 5400.1, "General Environmental Protection Program," and 5820.2A, "Radioactive Waste Management." It focuses on programmatic functions including providing pollution prevention awareness training, assessing and documenting waste generation and reduction, promoting source reduction and recycling, establishing a cost accounting system, and providing pollution prevention technology transfer. The objective of the INEL Pollution Prevention and Waste Minimization Program is to achieve a systematic reduction in the total generation of wastes. The plan that provides guidance for implementing the waste minimization program is documented in U.S. Department of Energy Idaho Operations Office Idaho National Engineering Laboratory Waste Minimization and Pollution Prevention Awareness Plan (DOE-ID 1995b). The plan applies to all INEL operations and associated support operations unless specifically exempted.

Radioactive and hazardous waste is managed by two directorates in the Environmental Operations Branch of LITCO. The Waste Operations and ER departments manage waste treatment and disposal facilities and environmental remediation and D\&D activities, respectively. 
The INEL Waste Minimization Program is administered in the Environment Safety and Health

Branch. A summary of the organization structure of LITCO is provided in Chapter 17.

\subsection{Radioactive and Hazardous Waste Streams and Sources}

The quantity and form of radioactive, hazardous, and mixed wastes generated from INEL's ER and D\&D activities are summarized in this section.

DOE/ID-10417, Rev. 6, Waste Stream Projections for Environmental Restoration at the Idaho National Engineering Laboratory of June 1995 (DOE-ID 1995c) contains estimated waste stream data for ER and D\&D projects. These data are revised twice annually. The estimated quantity and form of radioactive, hazardous, mixed, and nonhazardous wastes generated from each Waste Area Group (WAG) are summarized in Table 9-1. The waste forms may be solid, liquid, gas, sludge, debris, or soil. Wastes from D\&D activities include mixed low-level, hazardous, low-level radioactive, and municipal sanitary. Table 9-2 shows the estimated quantities and waste types for D\&D activities. The information and data presented represent an overview of projected waste streams. The safety analysis documentation for a specific activity will provide more detailed summaries of the solid, liquid, and gaseous waste streams and sources, including estimated inventories, or simply will reference the hazard identification of Chapter 3 and information in Chapter 2, if they contain this information.

The waste management process, waste sources and characteristics, and waste handling and treatment systems are discussed in the following sections.

\subsubsection{Waste Management Process}

The ER manager and personnel implement the comprehensive INEL Waste Minimization and Pollution Prevention Awareness Plan (DOE-ID 1995b). This plan prioritizes the generation of waste by giving preference to waste avoidance first, environmentally sound recycling second, treatment third, and disposal last. All personnel are responsible for pollution prevention and waste minimization, and receive training to support this responsibility.

Waste minimization methods applied to waste generation processes throughout the ER program are listed in Table 9-3. Although successful when applied, these methods are not universally employed for all applicable waste streams.

\subsubsection{Waste Sources and Characteristics}

Waste streams are divided into the following four general types: nonhazardous, hazardous, radioactive, and mixed wastes. Nonhazardous wastes include solid industrial/commercial wastes and liquid municipal sanitary wastes. Hazardous wastes are solid wastes as defined in 40 CFR 261. These wastes are either characteristic wastes or listed wastes. Hazardous waste may include Toxic Substances Control Act wastes such as polychlorinated biphenyls and asbestos. 
Table 9-1. Quantities and waste types from INEL WAGS.

\begin{tabular}{|c|c|c|c|c|c|c|c|}
\hline \multirow[b]{2}{*}{$\mathrm{WAG}^{\mathrm{a}}$} & \multirow[b]{2}{*}{ Location } & \multirow[b]{2}{*}{ Waste form ${ }^{b}$} & \multicolumn{4}{|c|}{ Waste type } & \multirow{2}{*}{$\begin{array}{c}\text { Total } \\
\text { estimated } \\
\text { quantity } \\
\left(\mathrm{m}^{3}\right)\end{array}$} \\
\hline & & & Radioactive $^{\mathbf{b}}$ & Hazardous $^{b}$ & Mixed $^{b}$ & Nonhazardous $^{\mathbf{b}}$ & \\
\hline 1 & $\begin{array}{l}\text { Test Area North } \\
\text { (TAN) }\end{array}$ & $\begin{array}{l}\text { Solid, liquid, debris, } \\
\text { soil, sludge }\end{array}$ & Low-level & Metals, organics & $\begin{array}{l}\text { Low-level (metals) } \\
\text { (organics) }\end{array}$ & $\begin{array}{l}\text { Industrial/ } \\
\text { municipal, scrap } \\
\text { metals, asbestos }\end{array}$ & $34,012,530$ \\
\hline 2 & $\begin{array}{l}\text { Test Reactor } \\
\text { Area (TRA) }\end{array}$ & Soil & Low-level & Metals & Low-level (metals) & $\begin{array}{l}\text { Industrial/ } \\
\text { municipal }\end{array}$ & $0^{\mathrm{d}}$ \\
\hline 3 & $\begin{array}{l}\text { Idaho Chemical } \\
\text { Processing Plant } \\
\text { (ICPP) }\end{array}$ & $\begin{array}{l}\text { Solid, liquid, soil, } \\
\text { sludge }\end{array}$ & Low-level & $\begin{array}{l}\text { Heavy metals, } \\
\text { organics }\end{array}$ & Low-level (metals) & $\begin{array}{l}\text { Industrial/ } \\
\text { municipal }\end{array}$ & 129,915 \\
\hline 4 & $\begin{array}{l}\text { Central Facilities } \\
\text { Area }\end{array}$ & $\begin{array}{l}\text { Solid, soil, debris, } \\
\text { sludge }\end{array}$ & low-level & $\begin{array}{l}\text { Organics, metals, } \\
\text { petroleum }\end{array}$ & $\begin{array}{l}\text { Low-level (metals) } \\
\text { (organics) }\end{array}$ & $\begin{array}{l}\text { Industrial/ } \\
\text { municipal }\end{array}$ & 6028 \\
\hline 5 & $\begin{array}{l}\text { Power Burst } \\
\text { Facility/ Auxiliary } \\
\text { Reactor Area }\end{array}$ & $\begin{array}{l}\text { Liquid, debris, soil, } \\
\text { sludge }\end{array}$ & Low-level & Metals, organics & $\begin{array}{l}\text { Low-level (organics) } \\
\text { (metals) }\end{array}$ & $\begin{array}{l}\text { Industrial/ } \\
\text { municipal, asbestos }\end{array}$ & 185,032 \\
\hline 6 & $\begin{array}{l}\text { Experimental } \\
\text { Breeder Reactor- } \\
\text { I/Boiling Water } \\
\text { Reactor } \\
\text { Experiment }\end{array}$ & Soil & Low-level & Petroleum & $\begin{array}{l}\text { Low-level } \\
\text { (chemicals) (metals) }\end{array}$ & $\begin{array}{l}\text { Industrial/ } \\
\text { municipal }\end{array}$ & 142,892 \\
\hline 7 & $\begin{array}{l}\text { Radioactive } \\
\text { Waste } \\
\text { Management } \\
\text { Complex }\end{array}$ & $\begin{array}{l}\text { Solid, liquid, gas, soil, } \\
\text { debris, sludge }\end{array}$ & Low-level & $\begin{array}{l}\text { Organics, inorganics, } \\
\text { heavy metals }\end{array}$ & $\begin{array}{l}\text { Low-level (organics, } \\
\text { inorganics) }\end{array}$ & Industrial/municipal & 485,278 \\
\hline
\end{tabular}


Table 9-1. (continued).

\begin{tabular}{|c|c|c|c|c|c|c|c|}
\hline \multirow[b]{2}{*}{$\mathrm{WAG}^{\mathrm{a}}$} & \multirow[b]{2}{*}{ Location } & \multirow[b]{2}{*}{ Waste form ${ }^{b}$} & \multicolumn{4}{|c|}{ Waste type } & \multirow{2}{*}{$\begin{array}{c}\text { Total } \\
\text { estimated } \\
\text { quantity } \mathrm{b}, \mathrm{c} \\
\left(\mathrm{m}^{3}\right)\end{array}$} \\
\hline & & & Radioactive $^{\text {b }}$ & Hazardous $^{b}$ & Mixed $^{b}$ & Nonhazardous ${ }^{b}$ & \\
\hline 10 & Various & $\begin{array}{l}\text { Liquid, soil, debris, } \\
\text { ordnance }\end{array}$ & $\begin{array}{l}\text { Low-level, } \\
\text { transuranic (TRU) }\end{array}$ & Explosives, organics & - & - & 6321 \\
\hline
\end{tabular}

a. Does not include D\&D wastes.

b. Total estimated quantity includes all radioactive, hazardous, mixed, and nonhazardous waste.

c. From DOE-ID-10417, Rev. 6, Waste Stream Projections for Environmental Restoration at INEL, June 1995 (DOE-ID 1995c).

d. All waste generation projection volumes were changed to $0 \mathrm{~m}^{3}$ because no further remediation is planned beyond the cap-in-place action. 
Table 9-2. Typical quantities and waste types from D\&D activities.

\begin{tabular}{|c|c|c|c|c|c|c|}
\hline \multirow[b]{2}{*}{ Location } & \multirow[b]{2}{*}{ Waste form ${ }^{a}$} & \multicolumn{4}{|c|}{ Waste type } & \multirow{2}{*}{$\begin{array}{c}\text { Total } \\
\text { estimated } \\
\text { quantity }{ }^{b, c} \\
\left(\mathrm{~m}^{3}\right) \\
\end{array}$} \\
\hline & & Radioactive $^{\mathbf{a}}$ & Hazardous $^{\mathrm{a}}$ & Mixed $^{\mathbf{a}}$ & Nonhazardous $^{\mathrm{a}}$ & \\
\hline TAN-LOFT Ancillaries & Solid, debris & Low-level & Lead & - & - & 62 \\
\hline $\begin{array}{l}\text { TAN-Technical Support } \\
\text { Facilities }\end{array}$ & Solid, debris, soil & Low-level & - & - & $\begin{array}{l}\text { Industrial, } \\
\text { asbestos, lead }\end{array}$ & 521 \\
\hline TRA-Engineering Test Reactor & Solid, debris & Low-level & - & $\begin{array}{l}\text { Low-level (lead, } \\
\text { metal) }\end{array}$ & $\begin{array}{l}\text { Industrial/ } \\
\text { municipal }\end{array}$ & 18,854 \\
\hline TRA-Materials Test Reactor & Solid, debris & Low-level & - & Low-level (metal) & $\begin{array}{l}\text { Industrial/ } \\
\text { müinicièịai }\end{array}$ & 23,350 \\
\hline $\begin{array}{l}\text { TRA-Test Train Assembly } \\
\text { Facility }\end{array}$ & Solid, debris & Low-level & - & Low-level (metal) & $\begin{array}{l}\text { Industrial/ } \\
\text { municipal }\end{array}$ & 126 \\
\hline $\begin{array}{l}\text { ICPP-Chloride Removal } \\
\text { System-CPP } 631,660,709,734\end{array}$ & Solid, debris, rubble, soil & Low-level & - & $\begin{array}{l}\text { Low-level } \\
\text { (hazardous) }\end{array}$ & Sanitary, debris & 8 \\
\hline $\begin{array}{l}\text { ICPP-Fuel Element Cutting } \\
\text { Facility-CPP 603CRS }\end{array}$ & Solid, debris & - & - & - & - & 87 \\
\hline $\begin{array}{l}\text { ICPP-Headend Processing } \\
\text { Plant-CPP } 640\end{array}$ & Debris & Low-level & - & - & - & 80 \\
\hline ICPP-High Level Waste Tank ${ }^{c}$ & - & - & - & - & - & \\
\hline $\begin{array}{l}\text { ICPP-Stored Fuel } \\
\text { Exterior-CPP 642, 740, } \\
\text { SRE-20 }\end{array}$ & Solid, rubble, soil & Low-level & - & $\begin{array}{l}\text { Low-level } \\
\text { (hazardous) }\end{array}$ & Sanitary, debris & 40 \\
\hline $\begin{array}{l}\text { ICPP-Waste Calcine } \\
\text { Facility-CPP } 633\end{array}$ & Debris & Low-level & - & $\begin{array}{l}\text { Low-level } \\
\text { (hazardous) }\end{array}$ & $\begin{array}{l}\text { Industrial/ } \\
\text { municipal }\end{array}$ & 1330 \\
\hline Auxiliary Reactor Area I & Solid, liquid, debris & Low-level & - & $\begin{array}{l}\text { Low-level } \\
\text { (inorganics) } \\
\text { TRU (organics, } \\
\text { heavy metals) }\end{array}$ & $\begin{array}{l}\text { Sanitary, wood } \\
\text { rubble }\end{array}$ & 1,228 \\
\hline Auxiliary Reactor Area II & Solid, debris & Low-level & - & $\begin{array}{l}\text { Low-level } \\
\text { (asbestos) }\end{array}$ & $\begin{array}{l}\text { Sanitary, } \\
\text { industrial }\end{array}$ & 29 \\
\hline
\end{tabular}


Table 9-2. (continued).

\begin{tabular}{|c|c|c|c|c|c|c|}
\hline \multirow[b]{2}{*}{ Location } & \multirow[b]{2}{*}{ Waste form ${ }^{\mathrm{a}}$} & \multicolumn{4}{|c|}{ Waste type } & \multirow{2}{*}{$\begin{array}{c}\text { Total } \\
\text { estimated } \\
\text { quantity, } \\
\left(\mathrm{m}^{3}\right)\end{array}$} \\
\hline & & Radioactive $^{\mathrm{a}}$ & Hazardous $^{\mathrm{a}}$ & Mixed $^{\mathbf{a}}$ & Nonhazardous ${ }^{\mathrm{a}}$ & \\
\hline Auxiliary Reactor Area III & Solid, debris & Low-level & - & $\begin{array}{l}\text { Low-level } \\
\text { (inorganics) }\end{array}$ & $\begin{array}{l}\text { Industrial/ } \\
\text { municipal., } \\
\text { asbestos }\end{array}$ & 1822 \\
\hline $\begin{array}{l}\text { Boiling Water Reactor } \\
\text { Experiment } \mathrm{V}\end{array}$ & Solid, debris, soil & Low-level & Cadmium & Low-level (lead) & $\begin{array}{l}\text { Scrap wood, } \\
\text { metal, asbestos }\end{array}$ & 666 \\
\hline \multicolumn{7}{|c|}{ a. From DOE-ID-10417, Waste Stream Projections for Environmental Restoration at INEL, Rev. 6, June 1995 (DOE-ID 1995c). } \\
\hline c. No data available. & & & & & & \\
\hline
\end{tabular}


Table 9-3. Waste minimization methods applicable to environmental restoration wastes.

\begin{tabular}{|c|c|c|c|c|c|c|}
\hline Waste type & Decontamination & Housekeeping & Reclamation & Recycling & Reuse & $\begin{array}{c}\text { Waste } \\
\text { segregation }\end{array}$ \\
\hline Radioactive waste & $\mathbf{X}$ & $\mathrm{X}$ & & & $\mathbf{X}$ & $\mathbf{X}$ \\
\hline Mixed waste & $\mathbf{X}$ & $\mathrm{X}$ & & & & $\mathbf{x}$ \\
\hline \multicolumn{7}{|l|}{ Hazardous wastes } \\
\hline Batteries & & & & $\mathrm{x}$ & $\mathrm{x}$ & \\
\hline Contaminated soils & & $\mathrm{X}$ & & & & \\
\hline Excessed soils & & $\mathrm{X}$ & $\mathrm{X}$ & $\mathbf{X}$ & & \\
\hline Excessed paint & . & $X$ & & & & \\
\hline Lead & $X$ & $\mathrm{X}$ & $\mathrm{X}$ & $\mathrm{X}$ & $\mathrm{x}$ & $\mathbf{X}$ \\
\hline Mercury & $\mathbf{x}$ & $\mathrm{X}$ & $\mathrm{X}$ & $\mathbf{x}$ & $\mathbf{X}$ & $\mathbf{x}$ \\
\hline Munitions & & $\mathbf{X}$ & 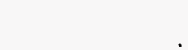 & & & \\
\hline Oxidizers & & $\mathrm{X}$ & & & & $x$ \\
\hline Paint thinners & & $\mathrm{X}$ & & $\mathrm{X}$ & $\mathrm{X}$ & \\
\hline Photo chemicals & & $\mathbf{X}$ & $\mathrm{X}$ & $\mathbf{X}$ & & \\
\hline Pyrophoric metals & & $\mathrm{x}$ & $\mathrm{X}$ & & & $\mathrm{x}$ \\
\hline \multicolumn{7}{|l|}{ Resource } \\
\hline \multicolumn{7}{|l|}{ Conservation and } \\
\hline \multicolumn{7}{|l|}{ Recovery Act } \\
\hline (RCRA) metal & & & & & & \\
\hline contaminated & $\mathrm{X}$ & $\mathrm{X}$ & $\mathrm{X}$ & & & $X$ \\
\hline wastes & $\mathrm{x}$ & $\mathbf{X}$ & & & $\mathbf{x}$ & $\mathbf{x}$ \\
\hline Solvent rags & & $\mathrm{X}$ & & $\mathrm{X}$ & $\mathbf{x}$ & \\
\hline Solvents & & $\mathrm{X}$ & & & & \\
\hline \multicolumn{7}{|l|}{$\begin{array}{l}\text { Waste hydrofluoric } \\
\text { acid }\end{array}$} \\
\hline \multicolumn{7}{|l|}{ Solid, nonhazardous } \\
\hline wastes & & & & $\mathrm{X}$ & $\mathrm{X}$ & \\
\hline Cardboard & & $\mathbf{X}$ & & $\mathbf{X}$ & $\mathbf{x}$ & \\
\hline Glass & & $\mathrm{X}$ & $\mathrm{X}$ & & & \\
\hline Masonry & & & & $\mathrm{x}$ & $\mathbf{X}$ & \\
\hline Metal & & & & $\mathbf{x}$ & $\mathrm{X}$ & \\
\hline Old fuel & & & & $\mathbf{X}$ & $\mathbf{X}$ & \\
\hline Packing material & & & & $\mathbf{X}$ & & \\
\hline $\begin{array}{l}\text { Used oil } \\
\text { Wood }\end{array}$ & & $\mathrm{X}$ & & & $x$ & \\
\hline
\end{tabular}


Radioactive waste consists of solid, liquid, or gaseous material that contains radionuclides regulated under the Atomic Energy Act. Mixed waste contains both radioactive and hazardous components as defined by the Atomic Energy Act and the RCRA.

The ER Waste Stream Tracking System is a centralized database management system that houses an inventory of waste information for all activities described by the INEL major system acquisition baseline summary (INEL 1994).

The Waste Stream Tracking System consists of several interconnected data bases that describe and define the following:

- Waste volumes

- $\quad$ Radionuclides

- Waste generated to date

- Forecasts of waste generation

- $\quad$ Anticipated TSD actions

- Anticipated TSD technology need dates

- Anticipated TSD volumes.

Tracking system data are generated from the following sources: waste sites within an Operable Unit, facilities targeted for D\&D, abandoned/out-of-service petroleum tanks, and abandoned/out-of-service hazardous and/or radioactive tanks. Data are gathered twice a year from ER and D\&D project personnel. The newly gathered information is analyzed for consistency and compared against data currently in the system. Other sources of information (such as the technical baseline section of the INEL major system acquisition baseline summary) are used to verify the consistency of the new information. If any information appears inconsistent or questionable, project personnel are contacted for clarification. New information is entered into the system and checked for accuracy. Updated data are returned to project personnel for final verification.

\subsubsection{Waste Handling or Treatment Systems}

9.4.3.1 Gaseous Waste Treatment and Ventilation. Gaseous wastes may be a byproduct of some environmental remediation and D\&D techniques. The methods chosen to control or mitigate gaseous waste from these activities will be governed by the following considerations:

- Concentration and characteristics of radioactive, hazardous, or mixed waste

- Exposure pathways and targets

- Probability of release or emission. 
The first consideration is relevant primarily because the concentrations and characteristics of radioactive or hazardous waste migrating from the site to the air will determine the appropriate control technology. Different waste forms (liquids, solids, and sludges, for example) as well as the volatility of hazardous constituents, permit variable amounts of gaseous release. Technologies will be selected to control potential gaseous releases during ER activities. These technologies may range from simple techniques such as wetting soil to more complex techniques such as scrubbing, activated carbon filtration, wet scrubbing, or similar offgas treatment methods.

The second consideration-exposure pathways and targets-involves identifying and evaluating the impact on the surrounding population and the environments. This information is crucial to protecting human life and the environment, especially any sensitive environments. Exposure pathways and targets will be analyzed prior to any ER activities, as specified under state and Federal regulatory requirements. Worker exposure will be analyzed in activity-specific health and safety plans.

The third consideration is the likelihood of a release of gaseous contaminants resulting from ER activities. Potential and actual release sources will be identified and controlled through passive and active perimeter gas control systems. Some of these systems confine gases in areas where they can be trapped and treated. The controls for gaseous waste during remediation include thermal destruction and incineration, which destroy organic components while trapping inorganics for further treatment by other methods including stabilization. Fugitive emissions may be controlled using dust suppressants, negative pressure air systems, foams, and covered shelters.

The operating philosophy and objectives of gaseous waste treatment are to prevent any regulatory concern releases (emissions) of hazardous gaseous wastes into the environment, using trap and treat technologies.

Gaseous wastes generated during ER activities may include hazardous, radioactive, and mixed wastes. The majority of gaseous wastes will be generated during treatment processes. Table 9-4 provides examples of waste streams and treatment technologies that require the control of gaseous wastes.

Treatment technologies for gaseous wastes will be determined prior to ER activities at any given site. Equipment and systems, engineering drawings, and flow paths to show location of equipment, crucial components, and instrumentation will be provided when technologies are selected.

Table 9-4. Gaseous waste treatment.

\begin{tabular}{|c|c|}
\hline Waste stream & Treatment \\
\hline Mixed low-level (chemical) in groundwater & $\begin{array}{l}\text { - Air stripping/carbon absorption/ion } \\
\text { exchange }\end{array}$ \\
\hline Hazardous (Organics) in soil & - Soil vapor vacuum extraction \\
\hline
\end{tabular}


9.4.3.2 Liquid Waste Treatment and Retention. Several methods are available for control or mitigation of the potential impacts of liquid radioactive, hazardous, and mixed wastes if treatment or storage activities are conducted at the INEL site during ER activities. These methods are summarized in Table $9-5$ by waste type.

Liquid waste includes purge water, spent solvents, liquid sanitary wastes, petroleum, D\&D liquids, and sludge. The operating philosophy and objectives for the management of liquid radioactive, hazardous, and mixed wastes are to minimize waste generation and to apply best demonstrated available technology to manage any waste generated. Measures to prevent or minimize spills or releases will be implemented to protect human life and the environment.

Treatment technologies for liquid wastes will be determined prior to ER activities at any given site. Equipment and systems, engineering drawings, and flow paths to show location of equipment, critical components, and instrumentation will be provided when technologies are selected.

9.4.3.3 Solid Waste Treatment and Retention. Methods employed to control or mitigate the potential impacts of solid waste (if treatment or storage is accomplished at the INEL site or facility) include various containment, immobilization technologies, and physical, thermal, chemical, and biological treatment methods. Specific technologies (Table 9-6) applicable to solid radioactive, hazardous, and mixed wastes are summarized below.

The operating philosophy and objectives for management of solid waste are to minimize the amount of solid radioactive, hazardous, and mixed wastes generated. Any wastes generated should be managed using the best technical standards available and in compliance with DOE directives, and state and Federal laws and regulations.

Table 9-5. Liquid waste treatment.

\begin{tabular}{lll}
\hline Liquid waste type & \multicolumn{1}{c}{ Applicable control methods } \\
\hline Radioactive waste & - & Evaporation \\
& - & Dewatering \\
& - & Packaging and special handling \\
Hazardous waste & - & Shipment to Waste Isolation Pilot Plant for disposal \\
& & Conversion of aqueous solution to a solid form for easy \\
& - & storage and disposal \\
& - & Neutralization and precipitation \\
Mixed waste & - & Filtration \\
& - & Solidification/fixation \\
& - & Storage until new disposal methods are identified \\
\hline
\end{tabular}


Table 9-6. Solid waste treatment.

\begin{tabular}{lll}
\hline Solid waste type & \multicolumn{1}{c}{ Applicable control methods } \\
\hline Radioactive waste & - & Stabilization/fixation \\
& - & Physical compaction \\
Hazardous waste & - & Solidification/stabilization \\
& - & Physical separation \\
& - & Chemical reduction \\
& - & Neutralization/precipitation \\
Mixed waste & - & Biodegradation \\
& - & Solidification/stabilization \\
& - & Storage until promulgation of management guidelines \\
\hline
\end{tabular}




\subsection{References}

Department of Energy Idaho Operations Office (DOE-ID 1995a), INEL Reusable Property, Recyclable Materials, and Waste Acceptance Criteria, RRWAC, DOE-ID-10381, Rev. 3, DOEID, Idaho Falls, ID.

Department of Energy Idaho Operations Office (DOE-ID 1995b), Waste Minimization and Pollution Prevention Awareness Plan, DOE-ID 10333 (95), Rev. 1, DOE-ID, Idaho Falls, ID.

Department of Energy Idaho Operations Office (DOE-ID 1995c), Waste Stream Projections for Environmental Restoration at Idaho National Engineering Laboratory, DOE-ID-10417, DOEID, Idaho Falls, ID, June 1995.

Idaho National Engineering Laboratory (INEL 1994), Environmental Restoration Major System Acquisition Baseline Summary, April 1. 


\section{INITIAL TESTING, INSERVICE SURVEILLANCE, AND MAINTENANCE}

\subsection{Introduction}

The following sections of Chapter 10 describe initial testing, inservice surveillance, and maintenance for Environmental Restoration (ER) program activities, including environmental remediation and decontamination and dismantlement (D\&D), at the Idaho National Engineering Laboratory (INEL).

Initial testing will be performed and documented to ensure performance as designed and the adequacy of the systems, components, and facilities involved in ER program activities. Initial testing will be conducted on new systems, components, and facilities before placement in service. Inservice surveillance and maintenance will be performed after the systems, components, and facilities are placed into service to ensure continued safe function and operation. At a minimum, the inservice surveillance will docurnent material conditions that indicate deterioration or improper operation, unsafe conditions, and apparent failures of components and safety equipment. Systems, components, and facilities will be maintained in a manner which promotes operational safety, worker health, environmental protection and compliance, property preservation, and cost-effectiveness.

ER program projects generally will be treated as construction sites subject to the applicable requirements of 29 CFR 1926. This regulation includes requirements for construction equipment, environmental controls, undergrourd construction, demolition, and other related safety issues.

Life safety requirements for this type of construction project differ from requirements for general industrial structures in normal operation.

The hazards and accident analyses, to be detailed in Chapter 3 of an activity-specific safety analysis report, will identify and analyze accident sequences that involve structures, systems, and components for their safety relevance during operations and maintenance activities. Also, potential equipment failures and the likelihood of human error during initial testing, surveillance, and maintenance could be considered as primary performance-shaping factors in the human reliability analysis in Chapter 13 . If postulated accidents result in significant onsite or offsite consequences, then initial testing, surveillance, and maintenance pertaining to radiological and chemical safety would be considered significant safety issues. Generally, however, standard industrial and manufacturer-recommended initial testing, inservice surveillance, and maintenance will be sufficient for Hazard Category 3 or less than the Hazard Category 3 threshold ER program activities, within the scope of this Baseline Safety Analysis File (BSAF).

\subsection{Requirements}

The following Codes of Federal Regulations, U.S. Department of Energy (DOE) orders, and other requirements are applicable to this chapter. These requirements are implemented by INEL manuals and procedures as indicated throughout this chapter.

- $\quad 29$ CFR 1926, "Safety and Health Regulations for Construction" 
- 40 CFR 265, "Interim Status Standards for Owners and Operators of Hazardous Waste Treatment, Storage, and Disposal Facilities"

- DOE-STD-3006-93, "Planning and Conduct of Operation Readiness Reviews (ORRs)," November 1993

- $\quad$ DOE Order 4330.4B, "Maintenance Management Program," February 10, 1994

- DOE Order 5480.31, "Startup and Restart of Nuclear Facilities," September 15, 1993.

\subsection{Initial Testing Program}

\subsubsection{Initial Testing and Inspection of New Facilities}

Initial testing and inspection will be conducted to analyze new systems, components, or facilities to ensure that basic design and safety specifications are satisfied. Initial testing and inspection will include the following elements:

- Compliance with design plans and configuration specifications

- Compliance with system and component operational specifications

- System and component material and manufacturer requirements

- Proper operation of safety devices and monitoring and alarm devices

- Operational capacities, speeds, throughputs.

\subsubsection{Operational Readiness Reviews and Readiness Assessments}

To demonstrate safety for startup (or restart) of an environmental remediation or D\&D activity, an independent review of readiness will be conducted as required by DOE Order 5480.31 . This order includes requirements for operational readiness reviews and readiness assessments that may be required dependent on the hazard category of the activity.

For environmental remediation and D\&D activities within the scope of the BASF, operational readiness reviews are required as follows:

- For the initial startup of new Hazard Category 3 activities

- For the restart of an activity after an unplanned shutdown directed by a DOE management official for safety, or because of operations outside the safety basis

- When deemed appropriate by DOE management officials.

An operational readiness review is a disciplined, systematic, documented, performance-based examination of facilities, equipment, personnel, procedures, and management control systems to 
ensure that an activity will be conducted safely within the approved safety envelope as defined by the activity safety basis. Operational readiness reviews require preparation of a formal plan of action, operational readiness review implementation plan, and final report. The resolution of all findings from the operational readiness review must be documented and maintained with the plan of action, implementation plan, and final report. The operational readiness review must be detailed and at least meet the minimum core requirements included in Attachment 2 of DOE Order 5480.31. These requirements include but are not limited to the following:

- Determine whether design and construction of facility meet required engineering and safety standards

- Develop procedures and documentation to ensure correct and safe operations of the facility or system

- Document qualification of personnel and implement training program

- Develop facility safety documentation including a program to confirm and periodically reconfirm the condition and operability of the safety system

- Conduct a systematic review of the facility conformance to applicable DOE orders, including a compliance schedule for cases of identified nonconformance

- Establish and implement emergency procedures program and maintain records

- Develop an adequate stajtup or restart test program that simultaneously confirms operability of equipment, viability of procedures, and the training of operators

- Review facility modifications to identify potential impacts on procedures, training, and qualifications.

DOE-STD-3006-93, "Planning and Conduct of Operation Readiness Reviews (ORRs)," provides additional guidance for the development and conduct of ORRs as required by DOE Order 5480.31 .

For startups and restarts of environmental remediation and D\&D activities not requiring an ORR, the need for a readiness assessment will be assessed in accordance with DOE Idaho Operations Office procedures. Readiness assessments follow a graded approach and may be short and simple for environmental remediation and D\&D activities below the Hazard Category 3 threshold.

\subsection{Inservice Surveillance Program}

\subsubsection{Scope}

Inservice surveillance is condurted to ensure that systems or components are operating in a safe manner and as intended for the operation involved, and to identify any existing or potential problems that could present a safety hazard to personnel, a threat to the environment, or damage 
to equipment. Requirements for inservice surveillance or inspections of hazardous waste storage . areas are contained in 40 CFR 265.174 for containers (such as 55-gal drums, overpacks, and portable tanks) and in 40 CFR 265.195 for tank systems (underground and aboveground). The scope of inservice surveillance will cover equipment, systems, or components involved in ER program activities. This includes instrumentation used to monitor areas for health and safety hazards such as radiation, airborne hazardous chemicals, and fires. Normal construction-type activities not involving any risks beyond that normally encountered in construction work will not require inservice surveillance (for example, removal of soil contaminated with low levels of hazardous materials or demolishment of a building with low levels of contamination that does not involve any specialized equipment or controls).

The level of surveillance required will depend on the type of system and components involved (for example, pumps, compressors, or high-pressure gas cylinders), the level of risk involved (that is, the type and amount of contaminants and hazardous materials involved), and the life cycle of the activity (short term vs. long term). Specific requirements for the type of instrumentation and inspections required will depend on the individual project. These requirements will be included in the health and safety plan, the operations and maintenance plan, or the system operating procedure. Requirements for conduct of inservice surveillance are contained in the Lockheed Idaho Technologies Company (LITCO) Conduct of Maintenance Manual (LITCO 1994) and the Westinghouse Idaho Nuclear Company (WINCO) Standard Operating Procedure No. WE-20, "Preventive Maintenance Activities" (WINCO 1990).

\subsubsection{Schedule}

Inservice surveillance activities will follow an approved schedule based on the hazards involved and any applicable codes or regulations. The potential hazards associated with specific equipment and systems, type of contamination present, and level of exposure to personnel will be factored into the schedule. Schedules for inservice surveillance will be developed as part of a system's or facility's operation and maintenance plan, or will be prepared as part of procedures required for the continued operation of facility equipment.

Table 10-1 provides examples of items to be included in a surveillance schedule and suggested frequency of inspections for those items. This table should be augmented with sufficient description and notes to ensure that adequate instruction is provided for personnel to perform the necessary surveillance actions. Inspection frequency will depend on potential hazards involved with a particular system or facility. Information in Table 10-1 is provided to demonstrate examples of best management practices and is not required by regulations, with the exception of inspections for hazardous waste containment and storage systems. Each surveillance requirement shall be performed within the specified time interval with a maximum extension of $25 \%$ of the specified interval between any two consecutive surveillances.

Each surveillance requirement will be evaluated concerning resultant safety effects and required actions to return to a safe operating condition if the surveillance requirement is not performed as specified. Resulting actions from nonperformance of surveillance requirements will depend on the specific potential hazard risks associated with nonperformance. 
Table 10-1. Examples of scheduled surveillance actions and frequency.

\begin{tabular}{|c|c|c|}
\hline Item & Inspection action & Inspection frequency \\
\hline $\begin{array}{l}\text { Radiation detection } \\
\text { instrumentation }\end{array}$ & $\begin{array}{l}\text { Check calibration date/verify } \\
\text { operation }\end{array}$ & Daily \\
\hline $\begin{array}{l}\text { Organic vapor detector } \\
\text { (\% lower explosive level } \\
\text { monitors) }\end{array}$ & $\begin{array}{l}\text { Check calibration date/verify } \\
\text { operation }\end{array}$ & Daily \\
\hline Fire/smoke detectors & Check operation & Weekly \\
\hline Fire suppression systems & Check operation & Monthly \\
\hline Treatment system alarms & Check status/operation & $\begin{array}{l}\text { Daily - Hazardous waste } \\
\text { operations } \\
\text { Weekly - Nonhazardous } \\
\text { operations }\end{array}$ \\
\hline $\begin{array}{l}\text { Hazardous waste } \\
\text { storage/containment structures }\end{array}$ & $\begin{array}{l}\text { Irspect condition of structure for signs } \\
\text { of leakage }\end{array}$ & Daily \\
\hline $\begin{array}{l}\text { Nonhazardous waste } \\
\text { storage/containment Structures }\end{array}$ & $\begin{array}{l}\text { Inspect condition of structure for signs } \\
\text { of leakage }\end{array}$ & Weekly \\
\hline $\begin{array}{l}\text { High-efficiency particulate air } \\
\text { filter, sand bed, or cartridge } \\
\text { filter }\end{array}$ & $\begin{array}{l}\text { Verify differential pressure within } \\
\text { operating limits }\end{array}$ & Daily \\
\hline Pumps & $\begin{array}{l}\text { Verify discharge pressure/differential } \\
\text { pressure/flowrate within operating } \\
\text { limits }\end{array}$ & $\begin{array}{l}\text { Daily - Hazardous waste } \\
\text { operations } \\
\text { Weekly - Nonhazardous } \\
\text { operations }\end{array}$ \\
\hline Charcoal filter & $\begin{array}{l}\text { Verify removal efficiency is within } \\
\text { operating limits }\end{array}$ & Weekly \\
\hline Alarms (high level, low flow) & Verify operation & $\begin{array}{l}\text { Daily - Hazardous waste } \\
\text { operations } \\
\text { Weekly - Nonhazardous } \\
\text { operations }\end{array}$ \\
\hline Piping systems & $\begin{array}{l}\text { Verify proper valve alignment/no } \\
\text { leakage }\end{array}$ & $\begin{array}{l}\text { Daily - Hazardous waste } \\
\text { operations } \\
\text { Weekly - Nonhazardous } \\
\text { operations }\end{array}$ \\
\hline Automatic control Systems & $\begin{array}{l}\text { Verify proper setting (auto/hand/off) } \\
\text { and operation }\end{array}$ & $\begin{array}{l}\text { Daily - Hazardous waste } \\
\text { operations } \\
\text { Weekly - Nonhazardous } \\
\text { operations }\end{array}$ \\
\hline Battery backup & $\begin{array}{l}\text { Verify charging system operation/ } \\
\text { batteries holding charge }\end{array}$ & $\begin{array}{l}\text { Weekly } \\
\text { Weekly }\end{array}$ \\
\hline Diesel generator & $\begin{array}{l}\text { Verify fuel tank full/generator } \\
\text { operation }\end{array}$ & $\begin{array}{l}\text { Weekly } \\
\text { Monthly }\end{array}$ \\
\hline
\end{tabular}




\subsubsection{Compliance with Applicable Codes and Standards}

Inservice surveillance schedules and activities will include adequate inspections to determine if systems or equipment are being operated in compliance with applicable codes and standards. Included in these inspections will be operating equipment that could affect compliance with applicable regulations relating to worker safety and environmental conditions.

\subsection{Maintenance Program}

\subsubsection{Compliance with DOE Order 4330.4B, "Maintenance Management Program"}

DOE Order 4330.4B provides policy and objectives for the establishment of programs to manage and perform maintenance and repair of DOE property, which includes facilities. The basic policy follows:

- Maintenance management programs for all DOE facilities shall be consistent with DOE Order 4330.4B

- Property shall be maintained to promote operational safety, worker health, environmental protection and compliance, property preservation, and cost-effectiveness

- Structures, components, and systems important to safe operation of a property or facility shall be subject to a maintenance program

- $\quad$ Periodic examination of structures, systems, components, and equipment shall be performed to determine deterioration or technical obsolescence.

Objectives of the maintenance policy ensure the reliability, safety, and operability of structures, systems, and components, and compliance with current environmental, safety, and health standards. Furthermore, it is stipulated that line management take a graded approach in developing and implementing maintenance programs.

A maintenance program as required by DOE Order 4330.4B will be developed, implemented, and documented to ensure that maintenance activities are conducted to preserve or restore the availability, operability, and reliability of structures, systems, and components important to safe and reliable operation of ER program activities. Periodic examinations will be included to determine whether deterioration has occurred and to identify and address technical obsolescence that threatens performance, safety, or facility preservation, if necessary. The maintenance program will consist of maintenance plans or procedures structured to satisfy the requirements of DOE Order 4330.4B and supplemented by specific stipulations relating to particular equipment requirements. Requirements of acceptance are contained in LITCO Conduct of Maintenance Manual and WINCO Maintenance Management Program (WINCO 1992). 
10.5.2 Limitations on Routine Maintenance and Repair on Components Important to Safety

Because engineered safety features and safety class structures, systems, and components are not expected to be required for Hazard Category 3 or lower-threshold activities, ER program activities, plans, provisions, or compensatory actions developed to prevent the limitations of maintenance and repair from degrading safety will not normally be required. Required compensatory actions related to limitations on the maintenance and repair of systems or equipment required to ensure worker safety will be included as part of the radiation protection and hazardous material protection programs (Chapters 7 and 8 ). 


\subsection{References}

Lockheed Idaho Technologies Company (LITCO 1994), Conduct of Maintenance Manual, LITCO, Idaho Falls, ID, December 15.

Westinghouse Idaho Nuclear Company (WINCO 1990), "Standard Operating Procedure: Preventive Maintenance Activities," WINCO, Idaho Falls, ID, WE-20.

Westinghouse Idaho Nuclear Company (WINCO 1992), WINCO Maintenance Management Program, WINCO, Idaho Falls, ID. 


\section{OPERATIONAL SAFETY}

\subsection{Introduction}

Conduct of operations denotes a philosophy for conducting operations that involve risks to personnel or the environment. Lockheed Idaho Technologies Company (LITCO) policy is that primary consideration in the conduct of operations is the health and safety of workers and the public, and protection of the environment. This chapter summarizes the conduct of operations program, which is documented in the EG\&G Idaho Conduct of Operations Manual (adopted by LITCO).

\subsection{Requirements}

The following Codes of Federal Regulations (CFRs) and U.S. Department of Energy (DOE) orders are applicable to this chapter. These requirements are implemented by LITCO via its adoption of the EG\&G Idaho manuals and procedures as indicated throughout this chapter.

- 29 CFR 1910.120, "Occupational Safety and Health Standards, Hazardous Waste Operations and Emergency Response"

- $\quad 29$ CFR 1926.150, "Construction Standard, Fire Protection"

- DOE Order 1324.5B, "Records Management Program," January 12, 1995

- DOE Order 5000.3B, "Occurrence Reporting and Processing of Operations Information," January 19, 1993; Chg 1, July 2, 1993

- $\quad$ DOE Order 5480.4, "Environmental Protection, Safety and Health Protection Standards," May 15, 1984

- $\quad$ DOE Order 5480.7A, "Fire Protection," February 17, 1993

- DOE Order 5480.19, "Conduct of Operations Requirements for DOE Facilities," July 9, 1990; Chg 1, May 18, 1992

- $\quad$ DOE Order 5480.23, "Nuclear Safety Analysis Reports," April 30, 1992

- DOE Order 5484.1, "Environmental Protection, Safety, and Health Protection Information Reporting Requirements," February 24, 1981, Chg 7, October 17, 1990

- DOE Order 5633.3B, "Control and Accountability of Nuclear Materials," September 7, 1994

- $\quad$ DOE Order 6430.1A, "General Design Criteria," April 6, 1989 
- DOE (EM-40), Decontamination and Decommissioning Guidance Document (Draft 3), January 14, 1994.

\subsection{Conduct of Operations}

The environmental restoration (ER) operations organization, which includes ER and Decontamination and Dismantlement (D\&D), will ensure that a high level of performance in operations is achieved through effective implementation and control of operations activities. Requirements of DOE Order 5480.19, "Conduct of Operations for DOE Facilities," are implemented in the EG\&G Idaho Conduct of Operations Manual as adopted by LITCO. This document is implemented as the prime conduct of operations policy for ER operations and establishes minimum requirements. Conduct of operations sections are applied as best management practices as deemed appropriate by the cognizant manager, and are applied to the degree consistent with implications of the facility hazard classification. The requirements of this document, as they are applicable to ER activities, are discussed in the following sections. Issues of operations organization, administration, and training are discussed in Chapters 12 and 17.

\subsubsection{Shift Routines and Operating Practices}

Safe work practices are established with written work procedures and work permits, as described in Chapter 12. ER activities are normally conducted during daylight hours in spring, summer, and autumn. If multiple shifts are required, it is usually the result of schedule requirements. Therefore the operations, routines, and practices are the same regardless of the particular shift.

This topic of DOE Order 5480.19 is implemented in a chapter of EG\&G Idaho Conduct of Operations Manual. It identifies the professional conduct and good watch-standing practices that result in appropriate attention to conditions. It also emphasizes effective equipment monitoring to detect abnormal or unsafe conditions so that appropriate action can be taken before equipment malfunctions or a hazard causes death or serious physical harm. Appropriate action includes prompt notification to supervisors to ensure that proper attention is given to potential problem areas.

\subsubsection{Control Area Activities}

Access to ER activity sites is controlled by physical security measures specified in activityspecific health and safety plans, as required by 29 CFR 1910.120 (b)(4)(ii)(F). The health and safety plans include the placement of work zones, including an exclusion zone, hot line, contamination reduction corridor, contamination reduction zone, and support zone, as well as standard operating procedures and safe work practices to be followed in controlled areas.

\subsubsection{Communications}

Various forms of communication are needed for safe and efficient operation at an ER site. Communications include but are not limited to face-to face conversation, radio, personal pagers, sound-powered phones, and special forms such as horns, lights, and bells. Controls ensure that 
these communication systems do not detract from normal operations and are available in an emergency. Examples of controls placed on communications systems include the use of standard terminology and a phonetic alphabet and the requirement to repeat back instructions. Periodic surveillance is conducted by management to ensure that correct communication procedures are used and that the systems are working correctly.

Supervisors are responsible for ensuring that employees working in the field are informed about potential hazard encounters. Activity-specific health and safety plans will define the extent and nature of communications to protect the work force, including how employees will be alerted during emergencies. If essential emergency communication systems are important to ensure safety, they will comply with specifications described in Chapter 13 for human factors engineering.

\subsubsection{Control of On-Shift Training}

Training programs and requirements related to qualification of instructors and documentation of training are discussed in Chapter 12.

\subsubsection{Control of Equipment and System Status}

Operations shall be conducted in accordance with written procedures covering such items as status change authorization, equipment lockout and tagout, post-maintenance testing, and alarm status and in compliance with safety and operating limits, technical specifications, operating safety requirements, operational safety procedures, safety analyses, or operating procedures. Safe and effective operations rely on knowing the current status of all equipment at any given time. The shift manager must authorize any change in status to major equipment or systems.

\subsubsection{Lockouts and Tagouts}

When there is a potential for equipment damage or personal injury during equipment operation, servicing, maintenance, or modification activities, a lockout and tagout procedure is employed. The procedure described in the EG\&G Idaho Conduct of Operations Manual is based on 29 CFR 1910 and DOE Order 5480.19, which require the use of danger tags, cautions tags, and locking devices to ensure that, before an employee performs any servicing or maintenance on a machine or equipment where the unexpected energizing, startup, or release of stored energy could occur and cause injury or equipment damage, the machine or equipment shall be isolated from the energy source and rendered inoperative.

\subsubsection{Independent Verification}

Independent verification is conducted to ensure management of correct condition of a process, system, or facility, without the bias of an individual perspective. Independent verification (the act of checking a condition, such as component position, separately from the activities related to establishing the condition) provides a high degree of reliability that operations conform to established criteria. The independent check is performed by an individual other than the person who established the initial condition or position, and the independent check is documented. A description of the types of systems, components, operations, or conditions requiring independent verification is provided in the EG\&G Idaho Conduct of Operations Manual. 


\subsubsection{Log Keeping}

The EG\&G Idaho Conduct of Operations Manual provides the direction for establishing and maintaining operating logs to record the data necessary to provide an accurate history of operations.

\subsubsection{Operations Turnover}

Implementing documents that describe operation turnover practices are generally not applicable to ER activities that are Hazard Category 3 or lower threshold criteria.

Normally, ER operations are performed on a one-shift-per-day (24-hr) basis. However, if multiple shift operations are performed, turnovers are conducted to ensure that oncoming shift managers and operators are aware of existing conditions, system lineups, problems, and planned evolutions before accepting responsibility for the operating position. Shift turnovers are guided by turnover checklists prepared by the off-going shift managers and operators. Shift turnovers include the status and lineup of major equipment, review of operating logs and records, facility walkdowns, exchange of information and responsibility by oncoming and off-going personnel, and crew briefings. Turnovers are also conducted for reliefs occurring during a shift to ensure that the oncoming person knows about conditions or status changes that may have occurred since the shift turnover.

\subsubsection{Operations Aspects of Facility Chemistry and Unique Processes}

Any sampling or other unique processes required will be handled according to the EG\&G Idaho Conduct of Operations Manual.

\subsubsection{Required Reading}

The EG\&G Idaho Conduct of Operations Manual provides instructions for establishing a uniform, formal required reading program to ensure that employees are made aware of information related to their job assignments.

\subsubsection{Timely Orders to Operators}

The EG\&G Idaho Conduct of Operations Manual establishes a procedure to provide instructions for the dissemination of essential short-term information and administrative instructions to affected individuals. The procedure also establishes the requirement for periodic review of documentation to remove outdated or obsolete information.

\subsubsection{Operator Aid Postings}

Operation aids serve an important function in safe operations by providing information useful to operators in performing their duties. Operator aids come in many forms, such as (a) portions or copies of controlled procedures, (b) portions or copies of controlled drawings, and

(c) information tags, curves, and graphs. Operator aid postings shall comply with the EG\&G 
Idaho Conduct of Operations Manual, which requires that all operator aids be maintained in an up-to-date configuration and authorized for use by cognizant management.

\subsubsection{Equipment and Piping Labeling}

Uniform equipment and piping labeling ensures that personnel are able to positively identify systems and equipment. The requirements for equipment and piping labeling are listed in the EG\&G Idaho Conduct of Operations Manual.

\subsubsection{Investigation of Abnormal Events}

A variety of abnormal events (ranging from fire, release of radioactive or hazardous materials, and equipment failure, to actual or attempted sabotage) may require a formal investigation and subsequent reporting. The EG\&G Idaho Conduct of Operations Manual describes an investigation program that was developed to comply with the requirements of DOE Orders 5484.1 and 5000.3B. It is policy that investigation programs ensure that the significant aspects of an abnormal event are identified and investigated; the root cause is determined; corrective actions necessary to prevent recurrence are determined, and deficiencies are corrected. The conditions or situations that require an abnormal event investigation are defined in the EG\&G Idaho Conduct of Operations Manual.

\subsection{Fire Protection}

\subsubsection{Fire Hazards}

In an activity-specific safety analysis report, this section will provide a realistic discussion of the magnitude of facility fire hazards in terms of overall combustible and explosive loading in proximity to hazardous materials being protected. The information should be based on and correlate with the fire hazards discussed in Chapter 3. Results of overall assessments, fire hazards analyses, and facility walkdowns would be discussed.

\subsubsection{Fire Protection Program and Organization}

Requirements for a compreherisive fire protection program were established by DOE Order 5480.7A, "Fire Protection." Objectives of the fire protection program include the following:

- Minimize potential for occurrence of a fire

- Ensure that a fire does not cause an onsite or offsite release of radiological and other hazardous material that will threaten the public health and safety or the environment

- Provide an acceptable degree of life safety to DOE and contractor personnel

- Ensure that process control and safety systems are not damaged by fire. 
It is LITCO policy to provide fire protection for Idaho National Engineering Laboratory (INEL) facilities that meets the requirements of the DOE-improved risk criteria, as defined in DOE Order 5480.7A and as implemented in the EG\&G Idaho Safety Manual. The objectives of the DOE-improved risk criteria are to ensure the following:

- No threats to public health or welfare will result from fire

- There are no undue hazards to employees from fire

- Vital DOE programs will not suffer unacceptable delays as a result of fire

- Property damage will be held to manageable levels.

The fire protection goals are (a) no measurable fire losses, and (b) full compliance with regulatory requirements.

ER places ongoing emphasis on fire protection principles by promoting employee awareness, using administrative controls and practices, and providing specific fire response training. Fire protection systems are addressed in Chapter 2.

The Company will operate Highly Protected Risk facilities characterized by a sufficient level of fire protection to fulfill requirements of insurability by Factory Mutual, Industrial Risk Insurers, or other private industrial fire insurance companies who limit their underwriting to the best protected class of industrial risks. Highly protected risk protection requires compliance with the fire protection and loss prevention standards detailed in DOE Order 5480.4, DOE Order 5480.7A, and DOE Order 6430.1A. This level of protection also includes (a) administrative procedures encompassing controls for hazardous substances; (b) processes; (c) inspection, maintenance, and testing of fire protection features; and (d) other programmatic fire safety activities.

For areas subject to significant life safety risks, serious property damage, program interruption, or loss of safety-class equipment as indicated in Chapter 3, additional protective measures may be deemed necessary as determined by the local authority with jurisdiction. These requirements, if applicable, will be documented in the activity-specific health and safety plan.

\subsubsection{Combustible Loading Control}

The LITCO fire protection policy is discussed in the EG\&G Idaho Safety Manual. Fire loadings are kept small for environmental remediation and D\&D activities through good housekeeping practices, procedures for maintenance of heat-producing equipment, proper handling and storage of flammable materials, and control of potential ignition sources. The fire and explosion hazards, storage practices for flammable, combustible, and reactive materials loading, mechanism for limiting combustible loading during operations and maintenance, and frequency of inspection will be discussed in an activity-specific health and safety plan. 


\subsubsection{Firefighting Capabilities}

The activity-specific health and safety plan required by 29 CFR 1910.120 will discuss the issues of fire protection and suppression. Section 29 CFR 1910.120 (c)(3) requires identification of potentially explosive or flammable situations. The emergency response section of the health and safety plan will address recognition of emergency situations, provision of emergency equipment, and coordination with emergency response organizations. Since ER activities involve construction, the provisions of 29 CFR 1926.150 will be followed. These provisions cover the placement of fire extinguisher types on construction sites. Fire extinguishers, when properly used, are the first line of defense in the event of a fire. If there is a credible potential for a release of chemical or radiological waste from fire, then further fire protection measures may be required for the site. The activity-specific health and safety plan is written to ensure and verify that sufficient provisions are made for the control of chemical risks associated with operation, maintenance, surveillance, and emergency response.

Fire protection support is available through the INEL Fire Department. The INEL Fire Department maintains three stations on the INEL site. The main station is located in the Central Facilities Area, Test Area North, and Argonne National Laboratory-West have substations. All three fire stations are staffed $24 \mathrm{hr} /$ day by career firefighters trained as emergency medical technicians. Each of the three stations has the equipment and expertise to respond to explosions, fires, spills, and medical emergencies. The INEL Fire Department maintains a specially equipped, hazardous materials vehicle used in the event of hazardous chemicals incidents.

The INEL Fire Department standard practices define the fire department's program, management, organization, staffing, response procedures, etc. Procedures and training are in place for dealing with required aspects of structural and wild land firefighting, emergency medical services, hazardous materials mitigation, and rescue. General training requirements are defined and outlined in agreements with firefighter's union.

\subsubsection{Firefighting Readiness Assurance}

The activity-specific health and safety plan contains a summary of the emergency response plan for the task site which includes, if applicable, summaries of the fire prevention inspection program and fire safety drills and exercises. When the task site is within the jurisdiction of an INEL facility with an existing fire prevention plan and/or fire protection program, pertinent details of those plans will be referenced or included in the activity's health and safety plan. Activities that are not within the boundary of a facility are covered by the CFA fire prevention plan and fire protection program.

DOE (EM-40), Decontamination and Decommissioning Guidance Document provides direction for the $D \& D$ process and for the health and safety responsibilities at $D \& D$ sites. Mandatory standards and requirements of DOE Order 5480.4 including fire protection are given. 


\section{PROCEDURES AND TRAINING}

\subsection{Introduction}

This chapter summarizes the processes by which the technical content of the procedures and personnel training are developed, verified, and validated for the conduct of normal, abnormal, and emergency operations. These processes ensure that environmental remediation and Decontamination and Dismantlement (D\&D) activities are conducted by personnel who are well qualified, and that procedures and training elements have been accurately developed and kept current.

Procedures and training processes have been developed to enhance personnel safety performance. With the exception of routine activities (such as janitorial, administrative, and yard work), all work is performed by trained employees operating in accordance with reviewed and approved procedures.

\subsection{Requirements}

The following Codes of Federal Regulations (CFRs), U.S. Department of Energy (DOE) orders, and other requirements are applicable to this chapter. These requirements are implemented by Lockheed Idaho Technologies Company (LITCO) via its adoption of the EG\&G Idaho and Westinghouse Idaho Nuclear Company (WINCO) manuals and procedures as indicated throughout the chapter.

- $\quad 10$ CFR 830.120, "Nuclear Safety Management, Quality Assurance Requirements"

- 29 CFR 1910, "Occupational Safety and Health Standards"

- $\quad 40$ CFR 265, "Interim Status Standards for Owners and Operators of New Hazardous Waste Treatment, Storage, and Disposal Facilities"

- DOE-STD-1029-92, "Writer's Guide for Technical Procedures," December 1992

- DOE Order 1324.5B, "Records Management Program," January 12, 1995

- DOE Order 4330.4B, "Maintenance Management Program," February 10, 1994

- DOE Order 5000.3B, "Occurrence Reporting and Processing of Operations Information," January 19, 1993

- DOE Order 5400.1, "General Environmental Protection Program," June 29, 1990

- DOE Order 5400.5, "Radiation Protection of the Public and the Environment," January 7, 1993 
- DOE Order 5480.11, "Radiation Protection for Occupational Workers," December 21, 1988

- DOE Order 5480.19, "Conduct of Operations Requirements for DOE Facilities," July 9,1990

- DOE Order 5480.20, "Personnel Selection, Qualification, and Training Requirements at DOE Nuclear Facilities," November 15, 1994

- DOE Order 5500.1B, "Emergency Management System," February 27, 1992

- DOE Order 5500.3A, "Planning and Preparedness for Operational Emergencies," April 30, 1991

- $\quad$ DOE Order 5700.6C, "Quality Assurance," August 21, 1991

- DOE Training Accreditation Program Manual

- DOE-ID Emergency Plan

- Nuclear Quality Assurance (NQA)-1, "Quality Assurance Program Requirements for Nuclear Facilities," September 15, 1989.

\subsection{Procedure Program}

The DOE in Order 5480.19, "Conduct of Operations Requirements for DOE Facilities," requires the preparation and use of written procedures to cover normal and abnormal (emergency) conditions. Furthermore, the development of written procedures is required for maintenance operations by DOE Order 4330.4B, "Maintenance Management Program." Format and style are in accordance with the standards and guidelines established by DOE-STD-1029-92, "Writer's Guide for Technical Procedures." The proper use of procedures helps in the management of identified risk for Idaho National Engineering Laboratory (INEL) environmental restoration (ER) activities including environmental remediation and decontamination and decommissioning. Required procedures are referenced in the activity-specific health and safety plan.

This section documents the processes by which the form and technical content of written procedures are developed, verified, and validated. Written procedures covering the conduct of operations during normal, abnormal, and emergency conditions, as well as surveillance, testing, and maintenance, support the safe remediation of environmentally contaminated sites and D\&D of facilities. Written procedures will be augmented by the health and safety plan or work plan, which identifies activity-specific hazards and establishes personnel and equipment protection. Also, procedures written for an individual facility may be applicable to an activity within the facility jurisdiction. Examples of procedures common to both environmental restoration and $D \& D$, unique to environmental restoration, and unique to D\&D are listed below. 
General Procedures. Examples of procedures common to both environmental remediation and D\&D include the following:

- Calibration and use of industrial hygiene monitoring equipment

- Calibration and use of health physics monitoring equipment

- Equipment decontamination procedures

- Personnel decontamination procedures

- Personal protective equipment selection protocols to include gloves, coveralls, and respirators

- Lockout/tagout procedures

- Confined space entry procedures

- Issuance of safe use permits such as "hot work" permits.

Procedures Unique to Environmental Remediation. Examples of procedures unique to environmental remediation include the following:

- Soil sampling procedures

- Monitoring well sampling procedures

- Monitoring well installation procedures

- Trenching and shoring.

Procedures Unique to D\&D. Examples of procedures unique to $D \& D$ include the following:

- Asbestos removal

- Abrasive blasting of surfaces

- Acetylene torch cutting of metal structures or components

- Material surface contamination sampling procedures.

\subsubsection{Development of Procedures}

Procedures are developed by individuals knowledgeable of the operation, distributed for review and comment to affected operations and facilities, and revised, as necessary, to reflect regulatory requirements. It is the responsibility of the preparer and those reviewing and 
approving the document to ensure that the procedures are adequate and complete. Reviewers ensure that significant risks have been identified, appropriate mitigating features have been provided, risks have been properly evaluated, and compliance with applicable requirements has been met. The approved procedure will be a controlled document and will be issued to holders of controlled copies of the manuals.

Table 12-1 summarizes the general procedure documentation requirements for procedure format, verification, approval, and issuance. LITCO has adopted the procedure documentation of EG\&G Idaho and WINCO (for the Idaho Chemical Processing Plant) as illustrated in the table. Procedures for remedial design/remedial action (RD/RA) activities are developed in accordance with the documentation of Parsons Engineering Science, Inc. These requirements cover the process of preparation or revision of procedures from the point that the need for a procedure or revision is identified by an individual/organization, to the point that a draft procedure or a procedure revision is forwarded for final processing.

\subsubsection{Maintenance of Procedures}

Procedures are reviewed for technical accuracy, completeness, and comprehensibility a minimum of every two years and revised, as necessary, to reflect current operating practices and requirements. Procedures are controlled to ensure that individuals have the most current copy. Documentation requirements for procedure changes, biannual review and update, and issuance of revised procedures are summarized in Table 12-1.

User training is performed through required reading, pre-job briefing, or formal classroom training, depending on the complexity of the procedure. Training requirements for procedures are determined and training is conducted, where applicable, as part of procedure implementation. The level of operator and safety training required is determined as part of the process design and hazards involved.

If human interaction to prevent or mitigate a significant hazard or accident is required by the analyses in Chapter 3, then human factors analysis methods (as described in Chapter 13) will be applied in developing the procedures. Human factors task analysis techniques will ensure that actions required by procedures are within normal human capabilities, and that the expectations for workers involved in ER activities are realistic and achievable.

Safety analysis requirements will also be included in procedures when needed to ensure that the safety bases documented in the environmental remediation or D\&D activity safety analysis documentation, technical safety requirements, and health and safety plan are met. Procedures may need to address safety analysis requirements pertaining to, but not limited to, staff qualifications, operating support, operational readiness reviews/readiness assessments, unreviewed safety question assessments, and radioactive and hazardous material inventory control/monitoring.

\subsection{Training Program}

The training program is designed to ensure that qualified and certified personnel are properly trained to perform specific job assignments. The program has three basic objectives: 
Table 12-1. Procedures documentation summary.

Implementing documents that establish process for meeting DOE requirements

\begin{tabular}{|c|c|c|c|}
\hline \multirow{2}{*}{$\begin{array}{l}\text { Procedure document } \\
\text { required by DOE } \\
\text { Order } 5480.19\end{array}$} & \multicolumn{3}{|c|}{ Procedure development documents } \\
\hline & EG\&G Idaho & WINCO & Parsons (RD/RA) \\
\hline $\begin{array}{l}\text { Procedure Format } \\
\text { Specification }\end{array}$ & $\begin{array}{l}\text { EG\&G Idaho, Inc. } \\
\text { Company Procedures } \\
\text { Manual, Section } 1.1\end{array}$ & $\begin{array}{l}\text { WINCO Standard } \\
\text { Operating Procedure } \\
\text { (WSOP) WA-4 } \\
\text { "Developing Standard } \\
\text { Operating Procedures". }\end{array}$ & $\begin{array}{l}\text { PARSONS INEL } \\
\text { RD/RA Project } \\
\text { Procedure PRO-001, } \\
\text { "Procedures } \\
\text { Development } \\
\text { Standard" }\end{array}$ \\
\hline Procedure Verification & $\begin{array}{l}\text { EG\&G Idaho, Inc. } \\
\text { Company Procedures } \\
\text { Manual, Section } 1.1\end{array}$ & $\begin{array}{l}\text { WSOP WA-4 } \\
\text { "Developing Standard } \\
\text { Operating Procedures" }\end{array}$ & $\begin{array}{l}\text { PARSONS INEL } \\
\text { RD/RA Project } \\
\text { Procedure PRO-001, } \\
\text { "Procedures } \\
\text { Development } \\
\text { Standard" }\end{array}$ \\
\hline Procedure Approval & $\begin{array}{l}\text { EG\&G Idaho, Inc. } \\
\text { Company Procedures } \\
\text { Manual, Section } 1.1\end{array}$ & $\begin{array}{l}\text { WSOP WA-11 } \\
\text { "Reviewing and } \\
\text { Approving Integrated } \\
\text { Plant Document } \\
\text { System (IPDS) } \\
\text { Documents" }\end{array}$ & $\begin{array}{l}\text { PARSONS INEL } \\
\text { RD/RA Project } \\
\text { Procedure PRO-001, } \\
\text { "Procedures } \\
\text { Development } \\
\text { Standard" }\end{array}$ \\
\hline $\begin{array}{l}\text { Lessons Learned } \\
\text { Changes }\end{array}$ & $\begin{array}{l}\text { EG\&G Idaho, Inc. } \\
\text { Company Procedures } \\
\text { Manual, Section } 1.1\end{array}$ & $\begin{array}{l}\text { WSOP WQ-10.4 } \\
\text { "Lessons Learned" }\end{array}$ & - \\
\hline $\begin{array}{l}\text { Biannual Procedure } \\
\text { Review \& Update }\end{array}$ & $\begin{array}{l}\text { EG\&G Idaho, Inc. } \\
\text { Company Procedures } \\
\text { Manual, Section } 1.1\end{array}$ & $\begin{array}{l}\text { WSOP WA-11 } \\
\text { "Reviewing and } \\
\text { Approving IPDS } \\
\text { Documents" }\end{array}$ & - \\
\hline $\begin{array}{l}\text { Issuance of Current } \\
\text { and Revised } \\
\text { Procedures }\end{array}$ & $\begin{array}{l}\text { EG\&G Idaho, Inc., } \\
\text { Company Procedures, } \\
\text { Manual, Section } 1.1\end{array}$ & $\begin{array}{l}\text { WSOP WA-17 } \\
\text { "Controlled } \\
\text { Distribution of IPDS } \\
\text { Documents }\end{array}$ & $\begin{array}{l}\text { PARSONS INEL } \\
\text { RD/RA Project } \\
\text { Procedure PRO-001, } \\
\text { "Procedures } \\
\text { Development } \\
\text { Standard" }\end{array}$ \\
\hline
\end{tabular}


- $\quad$ Provide training that meets or exceeds applicable training requirements on a schedule that enables maintenance of qualification and certification, enables employees to perform assignments in a safe and efficient manner, and provides opportunity for job enrichment and personal growth

- Maintain accurate records of all training performed and received, enabling both employees and managers to verify training status individually and organizationally, or by training subject

- $\quad$ Provide a training staff to administer the training program.

This section contains a summary of the training program for INEL environmental remediation and D\&D workers. The following sections contain descriptions of the development, maintenance, and modification of training materials.

\subsubsection{Development of Training}

DOE Order 5480.20, "Personnel Selection, Qualification, and Training Requirements at DOE Nuclear Facilities," defines training requirements for individuals who work at DOE facilities. General training required by DOE Order 5480.20 includes the following:

- General description of facilities

- Job-related policies, procedures, and instruction

- Radiological health and safety program

- $\quad$ Facility emergency plans

- Industrial safety program

- Industrial hygiene program

- Fire protection program

- Security program

- Quality assurance program.

The general training is augmented by specific training required for ER work. Generally, training is promulgated and required by various Occupational Safety and Health Administration (OSHA) regulations. OSHA training requirements are summarized in Table 12-2. Specifics of each type of training summarized in Table 12-2 may be found in the cited regulation. Training for radiation workers will be performed as required by the INEL Radiological Control Manual.

DOE Order 5480.18A is not applicable to ER activities at the INEL because work does not involve or require the operation of a nuclear reactor. Reactors or facilities in a standby status are 
Table 12-2. Training required uncler OSHA.

\begin{tabular}{|c|c|c|}
\hline Regulation number & Regulation name & Regulation training summary \\
\hline $\begin{array}{l}29 \text { CFR } 1910.95 \\
29 \text { CFR } 1926.52 \\
\text { DOE Order } 5480.10\end{array}$ & Occupational Noise Exposure & $\begin{array}{l}\text { Requires individuals potentially exposed to } \\
\text { noise levels above } 85 \mathrm{dBA}-8 \mathrm{hr} \text { time- } \\
\text { weighted average [ } 80 \mathrm{dBA} \text { (DOE 1985)] to } \\
\text { receive training on hazards of noise and } \\
\text { preventive measures. }\end{array}$ \\
\hline 29 CFR 1910.96 & Ionizing Radiation & $\begin{array}{l}\text { Requires training of individuals to work } \\
\text { safely in and around radiological areas; and } \\
\text { training to maintain individual radiation } \\
\text { exposures and radiation exposures to others } \\
\text { as low as reasonably achievable. }\end{array}$ \\
\hline 29 CFR 1910.119 & $\begin{array}{l}\text { Process Safety Management of } \\
\text { Highly Hazardous Chemicals }\end{array}$ & $\begin{array}{l}\text { Requires training of process operators for } \\
\text { any process which involves a specified } \\
\text { chemical above threshold quantity. Training } \\
\text { must include hazards, operating procedures, } \\
\text { safe work practices, and emergency } \\
\text { operations. }\end{array}$ \\
\hline 29 CFR 1910.120 & $\begin{array}{l}\text { Hazardous Waste Operations \& } \\
\text { Emergency Response }\end{array}$ & $\begin{array}{l}\text { 1. 40-hr initial training for work on } \\
\text { uncontrolled hazardous waste sites; } 3 \\
\text { days supervised onsite experience. } \\
\text { 2. 24-hr initial training for work on } \\
\text { hazardous waste site where no exposure } \\
\text { above established exposure limits is } \\
\text { anticipated; } 1 \text { day supervised onsite } \\
\text { experience. } \\
\text { 3. 8-hr annual update. } \\
\text { 4. 8-hr supervisor training. }\end{array}$ \\
\hline
\end{tabular}

29 CFR 1910:120

29 CFR 1910.134

29 CFR 1910.146

29 CFR 1910.147

29 CFR 1910.157

29 CFR 1910.1001

29 CFR 1926.58

29 CFR 1910.1025

29 CFR 1926.62
Emergency Response for Chemical Spill Cleanup Teams

Respiratory Protection

Confined Space Entry

Lockout/Tagout

Fire Extinguishers

Asbestos

Lead
Requires initial 24-hr training/8-hr update for chemical release cleanup crew.

Requires fit testing and training in use of specific respirator type for potential respirator user.

Requires training for entry into confined spaces.

Requires training of employees who maintain moving equipment in lockout/tagout before equipment serviced.

Requires training in use of fire extinguishers.

Requires training/medical monitoring for individuals potentially exposed above asbestos action level.

Requires training of individuals potentially exposed above lead action level. 
Table 12-2. (continued).

\begin{tabular}{lll}
\hline \multicolumn{1}{c}{ Regulation number } & \multicolumn{1}{c}{ Regulation name } & \multicolumn{1}{c}{ Regulation training summary } \\
\hline 29 CFR 1910.1030 & Medical Services \& First Aid & $\begin{array}{l}\text { Requires first aid-trained person at job site } \\
\text { when emergency medical services not } \\
\text { reasonably accessible. Requires training in } \\
\text { bloodborne pathogens. }\end{array}$ \\
29 CFR 1910.1200 & Hazard Communication & $\begin{array}{l}\text { Requires training in health hazards of } \\
\text { chemicals to which worker potentially } \\
29 \text { CFR } 1926.59\end{array}$ \\
& Trenching \& Shoring & $\begin{array}{l}\text { Requires training of individuals performing } \\
\text { excavations requiring shoring before entry. }\end{array}$ \\
\hline
\end{tabular}

exempt from this regulation. D\&D cannot be performed on an operating reactor, and environmental remediation does not involve reactors. However, DOE Order 5480.18A does apply to other INEL activities and is generally considered in the development of all INEL training programs; therefore, the principal criteria contained in DOE Order 5480.18B concerning the development of all INEL training programs will be followed in the development of training programs for ER activities at the INEL. These include the following:

- $\quad$ Systematic analysis of jobs to be performed

- Derivation of learning objectives from the analysis that describes desired performance after training

- Design and implementation of training based on learning objectives

- Evaluation of trainee mastery of objectives during training

- Evaluation and review of training based on performance of trained personnel in the job setting.

Training required for each activity may vary depending on hazards present. Training beyond general training provided to all employees will be included in each activity-specific health and safety plan or work plan. This training may include the following: 40-hr hazardous waste management training and associated updates, respiratory protection to include respirator fit testing, first aid, confined space entry, lockout/tagout, and lead, asbestos, and radiation safety. Table 12-3 summarizes required training for workers on ER projects.

\subsubsection{Maintenance of Training}

All training shall be documented. Individuals who attend courses sign an attendance sheet. A copy of the attendance sheet is forwarded to the training coordinator responsible for logging the training into a master data bank. Duplicate copies of all employee training records are maintained. 
Table 12-3. Specialized activity training.

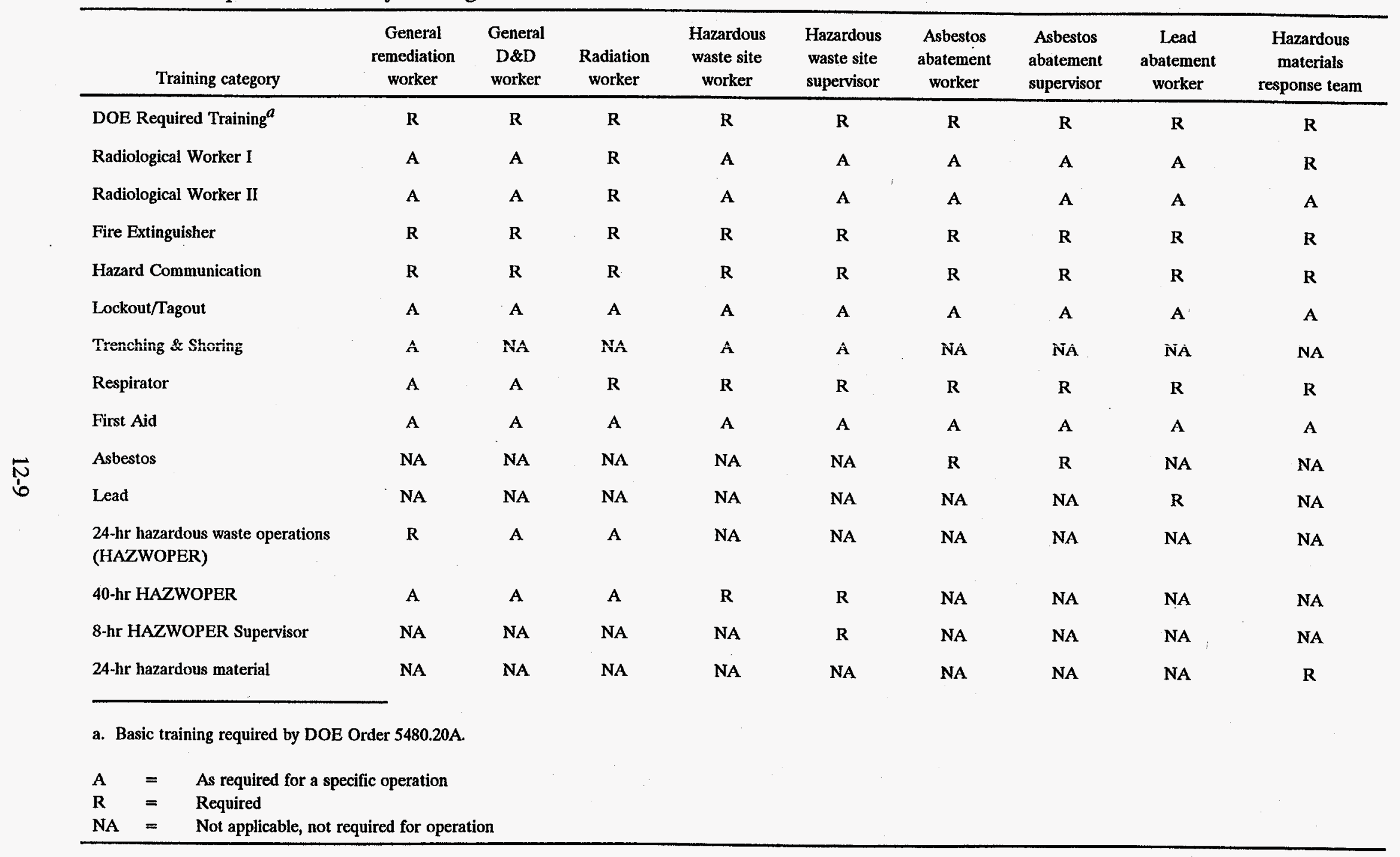


Table 12-4 summarizes the EG\&G Idaho and WINCO (for the Idaho Chemical Processing Plant) training documentation requirements as adopted by LITCO and those of the INEL RD/RA Program administered by Parsons Engineering Science, Inc.

Training is conducted by professional subject matter experts. Coleman Research Corporation provides technical trainers to the LITCO Technical Training Department, in the INEL Institute Directorate (see Chapter 17).

\subsubsection{Modification of Training Materials}

Technical and human factors deficiencies in training programs could be identified. If the analyses in Chapter 3 assume or require human interaction to prevent or mitigate a significant hazard or accident, human factors analysis methods will be applied in the development of training programs. Human factors methods are discussed in Chapter 13. The content and effectiveness of training programs will be established using human factors task analysis methods.

Safety analysis requirements will be included in training when needed to ensure that the safety bases documented in the environmental remediation or D\&D activity safety analysis documentation, technical safety requirements, and health and safety plan are met. Training may need to address safety analysis requirements pertaining to operating support, operational readiness reviews/readiness assessments, and radioactive and hazardous material inventory control/monitoring.

LITCO manages training programs as described in training manuals or safety and health manuals, such as EG\&G Idaho's Environmental Restoration and Waste Management Department Health and Safety Program and WINCO's Training Information Manual and Industrial Safety Manual. These manuals address such topics as methods to factor operating experience into training programs and methods to evaluate and improve the effectiveness of the training provided to operators, maintenance, and technical support personnel. Table 12-4 summarizes required documentation for modifications or updates to training. 
Table 12-4. Training documentation summary.

\begin{tabular}{|c|c|c|c|}
\hline \multirow{2}{*}{$\begin{array}{l}\text { Documentation } \\
\text { required } \\
\text { by DOE Order } \\
5480.20\end{array}$} & \multicolumn{3}{|c|}{ Training documents } \\
\hline & EG\&G Idaho & WINCO & Parsons (RD/RA) \\
\hline $\begin{array}{l}\text { Required training } \\
\text { identified }\end{array}$ & $\begin{array}{l}\text { EG\&G Idaho, Inc. } \\
\text { Company Procedures } \\
\text { Manual, Section 1-11 }\end{array}$ & $\begin{array}{l}\text { WSOP WT-3 } \\
\text { "Qualification and } \\
\text { Training" }\end{array}$ & $\begin{array}{l}\text { INEL RD/RA } \\
\text { Project, "Project } \\
\text { Training Plan" }\end{array}$ \\
\hline $\begin{array}{l}\text { Notification of } \\
\text { personnel }\end{array}$ & $\begin{array}{l}\text { Training Records and } \\
\text { Information Network } \\
\text { (TRAIN) }\end{array}$ & $\begin{array}{l}\text { WSOP ST-1, "Training } \\
\text { Administration" }\end{array}$ & $\begin{array}{l}\text { INEL RD/RA } \\
\text { Project, "Project } \\
\text { Training Plan" }\end{array}$ \\
\hline Training performed & TRAIN $^{a}$ & $\begin{array}{l}\text { WSOP ST-1, "Training } \\
\text { Administration" }\end{array}$ & $\begin{array}{l}\text { INEL RD/RA } \\
\text { Project, "Project } \\
\text { Training Plan" }\end{array}$ \\
\hline Training documented & TRAIN $^{a}$ & $\begin{array}{l}\text { WSOP WT-2, "Training } \\
\text { Records Management" }\end{array}$ & $\begin{array}{l}\text { INEL RD/RA } \\
\text { Project, "Project } \\
\text { Training Plan" }\end{array}$ \\
\hline $\begin{array}{l}\text { Training update } \\
\text { notification } \\
\text { procedures }\end{array}$ & TRAIN $^{a}$ & $\begin{array}{l}\text { WSOP ST-5 "Extending } \\
\text { Qualification for } \\
\text { Certification" }\end{array}$ & - \\
\hline
\end{tabular}

a. TRAIN is a computer records system. 


\section{HUMAN FACTORS}

Human error is involved in $50 \%$ to $90 \%$ of all abnormal occurrences in system settings. In the commercial nuclear arena, the U.S. Nuclear Regulatory Commission estimates that human error is involved in about $65 \%$ of all abnormal occurrences as a direct, indirect, or contributing cause. A wide range of person-machine and person-person factors enter into the human error equation. Some examples include misallocation of duties and responsibilities, technically inaccurate or incomplete training or operating procedures, poor supervisory or administrative controls, and poorly designed work environments.

As a scientific discipline, human factors applies behavioral and social sciences principles developed over the past century to system settings, with the goal of optimizing human and, ultimately, system performance. There are three somewhat overlapping areas within human factors: (a) human factors engineering (HFE), which primarily addresses human-machine interface issues, such as equipment design (e.g., displays, controls, and their juxtaposition), work space layout and accessibility, and environment (e.g., temperature, light, noise, radiation); (b) human system design, which primarily addresses human-task issues, such as allocation of duties and responsibilities, staffing, qualifications, selection, training, operating procedures, technical and administrative management, and organizational controls; and (c) human reliability analysis (HRA), which addresses both human-machine and human-task issues pertaining to human performance measurement, whether qualitative or quantitative, including probabilistic analysis. This chapter addresses the first area. The second area is addressed in Chapters 11, 12, and 17. HRA is an integral part of Chapter 3.

This chapter provides guidance in preparing the human portion of activity-specific safety analysis documentation.

\subsection{Introduction}

The policy in U.S. Department of Energy (DOE) Order 6430.1A, "General Design Criteria," is to ensure that appropriate human factors are considered in the design, operation, and maintenance of DOE's nonreactor nuclear facilities. Environmental remediation and Decontamination and Dismantlement (D\&D) activities at the Idaho National Engineering Laboratory (INEL) generally do not involve the design of new facilities, modification of existing facilities, or the risk of release of radioactive material offsite. However, when reliable human performance by an operating crew is important to safety, and in proportion to that importance to safety, DOE Order 5480.23, "Nuclear Safety Analysis Reports," requires a systematic inquiry into the optimization of the design of the human-machine interface. For environmental remediation and D\&D activities that are Hazard Category 3 or lower threshold, the importance of human factors is expected to be small, though there may be exceptions. The graded approach guidance given in DOE-STD-3009-94, "Preparation Guide for U.S. Department of Energy Nonreactor Nuclear Facility Safety Analysis Reports," indicates that human factors considerations should be documented if the hazard analyses or accident analyses (Chapter 3) assume or require reliable human interaction to mitigate or prevent a significant hazard or accident. 
Because human factors engineering is often applied to the design of industrial equipment and protective clothing used in the workplace, and human factors are considered during preparation of the activity-specific health and safety plan required by 29 CFR 1910.120 , "Hazardous Waste Operations and Emergency Response," for hazardous waste operations, routine application of human factors to mitigate common industrial hazards need not be described in the safety analyses. This chapter's discussion is limited to those areas in which human performance plays an important role in ensuring the performance of safety-significant systems, structures, and components (SSCs).

\subsection{Requirements}

The following Codes of Federal Regulations (CFRs) and DOE orders are applicable to this chapter:

- 29 CFR 1910, "Occupational Safety and Health Standards"

- 29 CFR 1926, "Occupational Safety and Health Standards"

- DOE-STD-3009-94, "Preparation Guide for U.S. Department of Energy Nonreactor Nuclear Facility Safety Analysis Reports," July 1994

- DOE Order 5480.4, "Environmental Protection, Safety \& Health Protection Standards," May 15, 1984

- DOE Order 5480.19, "Conduct of Operations Requirements for DOE Facilities," July 9,1990

- DOE Order 5480.20A, "Personnel Selection, Qualification and Training Requirements for DOE Nuclear Facilities," November 15, 1994

- $\quad$ DOE Order 5480.23, "Nuclear Safety Analysis Reports," April 30, 1992

- $\quad$ DOE Order 4330.4B, "Maintenance Management Program," February 10, 1994

- $\quad$ DOE Order 6430.1A, "General Design Criteria," April 6, 1989.

\subsection{Human Factors Process}

Environmental restoration activities in which human interaction is assumed or required to prevent or mitigate a significant hazard or accident will be identified from the analyses in Chapter 3. Human factors may become significant in activities including the following: potential hazards related to managing radioactive and hazardous wastes; release or spill of gases, liquids, and solids contaminated with radioactive and hazardous wastes; accidents involving some or all of the radioactive and hazardous waste inventories potentially generated and managed at the environmental remediation and $D \& D$ sites; and consequences of a major accident requiring the evacuation of the environmental remediation and D\&D sites. Human factors can become 
significant to personnel and may cause or contribute to improper handling of an accident involving radioactive or hazardous wastes from environmental restoration activities. Proper procedures, adequate training, alertness during work, effective systems control, communications, and proper operation of equipment and machines are methods applied to avoid potential human errors.

For each activity, the HFE will consist of three parts. First, the hazard analysis and accident analysis (Chapter 3) should be reviewed to determine the importance to safety of human-machine interactions. For example, the accident analysis should discuss failure modes of either equipment or personnel found to be particularly "important to safety."

Second, the criteria, standards, and requirements pertaining to the design of respective manmachine interfaces should be listed. Applicable requirements from DOE Orders 5480.23 and 6430.1A, Section 1300-12 should be listed. Criteria for meeting each requirement should be identified from human-factors engineering standards referenced by DOE, including the following:

- American National Standards Institute/Human Factors Society (1988), "Human Factors Engineering of Visual Display Terminal Work Stations;" Standard 100-88, February 4

- United States Department of Defense (DOD 1989), "Human Engineering Design Criteria for Military Systems, Equipment, and Facilities," MIL-STD-1472D, March

- Institute of Electrical and Electronic Engineers (1988), "Guide for the Application of Human Factors Engineering to Systems, Equipment, and Facilities of Nuclear Generating Stations," Standard 1023, October

- Nuclear Regulatory Commission (1981), Guidelines for Control Room Design Reviews, NUREG-0700, September

- Nuclear Regulatory Commission (1985), Human Engineering Guidelines for the Evaluation and Assessment of Video Display Units, NUREG/CR-4227, July

- University of California Research Laboratory (1985), Human Factors Design Guidelines for Maintainability of Energy Nuclear Facilities, UCRL-15673, June.

Standards and criteria relevant to the human factors evaluation may be found in Occupational Safety and Health general industry and construction standards. Some examples include the following: 29 CFR 1926.200, "Accident Prevention Signs and Tags;" 29 CFR 1926.201, "Signaling;" 29 CFR 1926.416, "Lockout and Tagging of Circuits;" 29 CFR 1926.860, "Selective Demolition by Explosives;" 29 CFR 1910.119, "Process Safety Management of Highly Hazardous Chemicals;" 29 CFR 1910.144, "Safety Color Code for Marking Physical Hazards;" and 29 CFR 1910.147, "The Control of Hazardous Energy" (lockout/tagout). Additional human factors standards designated by DOE may be found indexed in DOE Order 5480.4, "Environmental Protection, Safety, \& Health Protection Standards," under the topics Industrial Safety and Industrial Hygiene. The results of human factors engineering evaluations are interpreted in the context of complying with applicable radiological, chemical, and industrial safety requirements of DOE. 
Third, after significant human factors issues in Chapter 3 are identified and DOE-approved safety and health standards are reviewed to select applicable criteria for evaluating compliance, the environmental remediation or D\&D facility (or applicable design documents if no facility exists) will be examined to evaluate specific human factors engineering issues relevant to design. Deficiencies will be noted, and an evaluation made of the relevance of each deficiency, of the potential to mitigate each deficiency through administrative controls, and of deficiencies to be addressed by engineering design of facilities or equipment. Checklists can be used to satisfy the human factors safety requirements of DOE Order 5480.23, "Nuclear Safety Analysis Reports." According to DOE-STD-3009-94, "Preparation Guide for U.S. Department of Energy Nonreactor Facility Safety Analysis Reports," these would "examine

- $\quad$ preparation, validation, and use of written procedures

- $\quad$ qualification and training of operating crews

- $\quad$ staffing

- design of the human-machine interfaces; and

- $\quad$ allocation of control functions to workers versus automatic devices."

A series of checklists which supports safety analyses of DOE reactor and nonreactor facilities and activities is contained in the report Human Factors Engineering Checklists for Application in the SAR Process (Overline 1995).

\subsection{Identification of Human-Machine Interfaces}

Because Hazard Category 3 facilities and operations do not have safety-class SSCs, this section will summarize any human-machine interfaces with safety-significant SSCs. Structures, areas, and equipment that require human-machine interfaces to function shall be listed here in conjunction with the results of the hazard and accident analysis in Chapter 3. Included are human-machine interfaces for surveillance and maintenance of safety SSCs and for safety function during normal, abnormal, and emergency operation. Human actions and their importance to safety will be described.

\subsection{Optimization of Human-Machine Interfaces}

This section will summarize (a) HFE analysis results of compliances and deviations from full compliance with identified standards and (b) a systematic inquiry into the optimization of humanmachine interfaces with safety SSCs to enhance human performance. The analyses should be appropriate to the importance of the system and the level of risk associated with system failure.

The following sections provide additional information on principles of human behavior related to safety, component arrangement, and environmental considerations that may be useful in the human factors evaluation to maximize human performance. 


\subsubsection{Principles of Human Behavior Related to Safety}

The following section paraphrases U.S. DOD (1981) guidelines for designing or selecting equipment which incorporates the human behavior aspect of human factors. These principles are considered applicable to engineering design considerations for environmental restoration activities.

The principles in this section are based on how workers actually use equipment in the field, and on what may actually occur during equipment use. These principles address human error, misuse of equipment, and other behaviors that lead to unsafe actions. The following human behavior principles related to safety can be applied to any system design:

- Adequate equipment should be provided that is properly designed to do the task effectively to avoid increased risk and/or degraded performance that may result if equipment users modify equipment or violate procedures

- Procedures should be comprehensive, understandable, and require only tasks or operations within the physical and knowledge capabilities of affected personnel

- Equipment should be designed to more easily be used safely than unsafely, and to minimize the potential for and consequences of misuse

- Proposed controls of identified hazards should be evaluated to assess level of effectiveness

- When appropriate, realistic tests should be conducted with mockups and prototypes to verify that the system will work

- Equipment should be designed and procedures written to take advantage of operator expectations to minimize errors

- Equipment should be designed to minimize the necessity for warnings on the equipment or in operations manuals

- Training protocols should be established to ensure quality and promote standardization. Identification of hazards and an explanation of potential consequences of unsafe behavior should be addressed in training

- Equipment should be designed to be inherently safe to use, rather than relying on special safety training to prevent accidents

- Sound engineering principles, management support, approved procedures, and jobspecific training should be ensured for equipment, tools, or processes

- Designers should provide complete, legible, understandable identification of parts potentially damaged or injurious if incorrectly identified

- If used, checklists should be verified for clarity and completeness 
- Equipment should be chosen that is easy to use and maintain.

In summary, most safety problems in operational equipment arise not from defects in the equipment, but because of improper use. Therefore, designers must strive to anticipate how equipment might be misused and design so misuse becomes unlikely and effects of misuse are not catastrophic.

\subsubsection{Component Arrangement}

All controls and displays used as part of the environmental remediation system shall be designed to promote efficient use of task-related components, rapid location, and operator awareness. The following, according to DOE Order 6430.1A, "General Design Criteria," are some of the component arrangement concepts to be considered in the design or selection of equipment:

- Components should be grouped on the basis of specific criteria for tasks to be accomplished; alternative groupings, based on the sequence or frequency of use, should be considered

- Groupings by graphic-spatial methods such as demarcation and spacing of components should be emphasized

- Components should not be hidden within a component grouping

- A mirror image arrangement of components should be avoided

- Displays should be placed above and close to the related control

- When several components related by flow direction (valve-pump-valve) are placed in sequence, the direction of the sequence (top-to-bottom, left-to-right) should be consistent for each similar situation

- Component grouping techniques, system mimics, and system demarcation should be labeled in a hierarchical manner

- Component control actuation mode should be simple (on/off/auto)

- Labels on all components should be legible and conform to human visual capabilities

- Equipment and safety-related parts of equipment should be identified by approved labels. The label must state clearly and concisely the function and purpose of the item

- Labels should be easily understood, and label design should be consistent.

\subsubsection{Work Environment Factors}

Work environment factors that might degrade the performance of operations personnel are important to consider in enhancing human performance. Work environment factors include 
physical access, the need for protective clothing or breathing apparatus, noise levels, temperature, humidity, distractions, and other factors bearing upon physical comfort, alertness, or fitness. Also, environmental conditions that can impair human performance may be associated with environmental restoration activities. These factors are addressed in the activity-specific health and safety plan.

Some work environment factors are covered by codes and standards for which DOE Order 5480.4, "Environmental Protection, Safety and Health Protection Standards," requires compliance. Examples of construction safety and health regulations that address environmental work factors include 29 CFR 1926.56, "Illumination;" 29 CFR 1926.28, "Personal Protective Equipment;" 29 CFR 1926.52, "Occupational Noise Exposure;" 29 CFR 1926.53, "Ionizing Radiation;" 29 CFR 1926.103, "Respiratory Protection;" 29 CFR 1926.353, "Ventilation and Protection in Welding, Cutting, and Heating;" and 29 CFR 1910.146, "Confined Space Entry." . Methods to be used to comply with these regulations, particularly the use of personal protection equipment and necessity for confined space entry, are addressed in activity-specific health and safety plans.

The safe conduct of activities requires that involved personnel be alert, aware of responsibilities, and qualified to perform required tasks. Environmental conditions that can impair human performance and may be associated with environmental restoration activities include the following:

- Extreme weather conditions resulting in heat stress or hypothermia

- $\quad$ Poor lighting

- Use of personal protective equipment to protect against radiation and hazardous materials

- High levels of noise or vibrations that irritate or distract personnel.

The human factors considerations in controlling environmental conditions will be addressed in the activity-specific health and safety plan. This plan specifies procedures for work in extreme weather, reducing high noise levels, operational approaches including work/rest regimens to mitigate heat stress, and minimum illumination levels. 


\subsection{References}

American National Standards Institute, Inc. (ANSI 1989), "American National Standards Safety Requirements for Confined Spaces," ANSI, N.Y., N.Y., Z117.1-1989.

American National Standards Institute/Human Factors Society, (ANSI/HFS 1988), "Human

Factors Engineering of Visual Display Terminal Work Stations," Standard 100-88, February 4.

Department of Defense (DOD 1981), Human Factors Engineering Design for Army Material.

Department of Defense (DOD 1989), Human Engineering Design Criteria for Military Systems, Equipment, and Facilities, MIL-STD-1472D, March.

Institute of Electrical and Electronic Engineers (IEEE 1988), "Guide for the Application of Human Factors Engineering to Systems, Equipment, and Facilities of Nuclear Generating Stations," Standard 1023, October.

Nuclear Regulatory Commission (NRC 1981), Guidelines for Control Room Design Reviews, NUREG-0700, September.

Nuclear Regulatory Commission (NRC 1985), Human Engineering Guidelines for the Evaluation and Assessment of Video Display Units, NUREG/CR-4227, July.

Overlin, T.K., Romero, H.A., Ryan, T.G., Human Factors Engineering Checklists for Application in the SAR Process, INEL-95/0117, March 1995.

University of California Research Laboratory (UCRL 1985), Human Factors Design Guidelines for Maintainability of Energy Nuclear Facilities, UCRL-15673, June. 


\section{QUALITY ASSURANCE}

\subsection{Introduction}

This chapter describes the provisions of the quality assurance program implemented by Lockheed Idaho Technologies Company (LITCO) via LITCO's adoption of the EG\&G Idaho Quality Manual. This quality assurance program achieves and ensures safety and environmental protection associated with environmental restoration (ER) activities.

\subsection{Requirements}

The following Codes of Federal Regulations (CFRs), U.S. Department of Energy (DOE) orders, and other requirements are applicable to this chapter. These requirements are implemented by LITCO via its adoption of the EG\&G Idaho manuals and procedures as indicated throughout the chapter.

- $\quad 10$ CFR 830.120, "Nuclear Safety Management, Quality Assurance"a

- $\quad$ DOE Order 1324.5B, "Records Management Program," January 12, 1995

- DOE Order 5700.6C, "Quality Assurance," August 21, 1991

- DOE-EM-5502-94, "Hazard Baseline Documentation"

- Military Standard MIL-STD-45662A (DOD 1988).

\subsection{Quality Assurance Program and Organization}

\subsubsection{Program}

Work performed at ER activities is scheduled, implemented, and performed by LITCO and subcontractor personnel. The organizational interfaces within ER and other organizations are detailed in Chapter 17. As indicated in Chapter 17, the Office of the President branch provides quality support to ER via the Quality Assurance and Oversight Directorate. Independent assessments and audits are performed by the Quality Systems and Service Department and by Coleman Research Corporation (CRC).

\subsubsection{Personnel Qualification and Training}

The achievement of a quality product or service is the responsibility of the manager and employees, consistent with their level of responsibility. Each employee receives indoctrination and training requisite with assigned activities and level of responsibility. This training introduces the basic concepts of quality and discusses the role that each individual can play in quality

a. Applicable only to nuclear activities. 
improvement. Management is responsible for providing training to operations personnel on new or significantly revised quality procedures to ensure that acceptable proficiency, knowledge, and understanding of quality assurance principles are achieved and maintained. The requirements for personnel training and qualifications are set forth in 10 CFR 830.120 and DOE 5700.6C.

\subsection{Quality Improvement}

Management encourages personnel to identify problems and suggest improvements. Personnel are given the freedom and authority to stop work until effective corrective action is taken. Furthermore, anyone may cause work to stop for any condition or practice presenting an immediate hazard that could reasonably be expected to cause death or serious physical harm, or if the work poses a threat to the environment or to historical, archeological, or other irreplaceable cultural resources.

Procedures are in place to allow each individual to recommend improvements or to identify problems with existing processes. Personnel ensure that items that do not conform to requirements are controlled to prevent the inadvertent use or installation of those items. A nonconformance report, in accordance with the EG\&G Idaho Company Procedures Manual, Section 9.7, "Nonconformances," is used to report and control nonconforming items or products.

\subsection{Documents and Records}

Policy for the control of documents that specify quality requirements, establish design, or prescribe activities or procedures affecting quality is stated in 10 CFR 830.120 for nuclear activities and in DOE Order $5700.6 \mathrm{C}$ for nonnuclear activities. Documents are required to be prepared, reviewed, approved, issued, used, and revised in a controlled manner. To this end, the Administrative Record and Document Control (ARDC) system and an independent review committee have been established in the Environmental Operations (ER) Directorate of LITCO according to Management Control Procedure (MCP) 230, "Environment Restoration Document Control Center Interface" and Program Directive (PD) 4.8, "Internal and Independent Review of Documents." For RD/RA documents, Parsons Engineering Science, Inc., has established INEL RD/RA Project Procedures ENG-001, ENG-002, and ENG-003 for document review.

Quality records are maintained consistent with the requirements of 10 CFR 830.120 or DOE Order $5700.6 \mathrm{C}$ to ensure the maintenance and retrievability of objective evidence of quality.

\subsection{Quality Assurance Performance}

\subsubsection{Work Processes}

ER structures, systems, and components will be examined through a graded approach. As discussed in DOE-EM-STD-5502-94, Hazard Baseline Documentation, graded approach means "a process by which the levels of analysis, documentation, and actions necessary to comply with the requirements are commensurate with (a) the relative importance to safety, safeguards, and security; (b) the magnitude of any hazard involved; (c) the life cycle stage of a facility; (d) the 
programmatic mission of a facility; (e) the particular characteristics of a facility; and (f) any other relevant factor."

Work processes are controlled in accordance with 10 CFR 830.120 or DOE Order 5700.6C. Management ensures that controls are provided for all processes that control or verify quality. Operations and maintenance routinely involve the control of processes where quality cannot be verified by final inspection alone. These processes depend instead on the operator's skill, equipment capability, and process parameters for assurance of quality, and generally fall into the categories of special inspection processes and special manufacturing processes.

Special processes include nondestructive examination, which is used to verify the structural integrity of items. Nondestructive examination is performed by certified personnel using approved procedures. The Environment, Safety, and Health division certifies the examiners. Special manufacturing processes include metallurgical, potting/polishing, joining (welding and brazing), and heat treating. Welding personnel certifications and weld procedure qualifications are in accordance with the EG\&G Idaho Company Procedures Manual, Section 15.1, "Qualification of Welding and Brazing Personnel," Section 15.2, "Welding and Brazing Procedure Qualification," and Section 15.3, "Engineering, Manufacturing, and Maintenance Welding Requirements."

For assigned work to parties outside ER, management controls are established, responsibilities are assigned, and lines of communication are identified. Initial estimates used in planning are based on sound data and assumptions, material and service costs, availability, and productivity. minimum:

Readiness reviews are performed before major scheduled or planned work to verify that, at a

- Work prerequisites have been satisfied

- Detailed technical and quality assurance procedures have been reviewed for adequacy and appropriateness

- $\quad$ Personnel have been suitably trained and qualified

- $\quad$ Proper equipment, materials, and resources are available.

Responsibility and authority to stop unsatisfactory work is assigned so that planning and schedule considerations do not override safety considerations. After any stop-work action, a restart review [as detailed in the LITCO Management Policies Manual, (in transition), Section 5D] is prepared and performed to provicle reasonable assurance that the facility, test, or system is proceeding safely and effectively, and that the residual risks of proceeding have been identified and accepted by the appropriate level of management. Concurrence by the DOE Idaho Operations Office is required. 


\subsubsection{Design}

The ER manager, or a designated alternate, ensures that design work performed for activities or systems is defined, controlled, and verified consistent with the requirements in 10 CFR 830.120 or DOE Order 5700.6C. Design inputs, analysis, verification requirements, and output documents are identified per the EG\&G Idaho Company Procedures Manual. For each design planning tabulation, a quality level is assigned to the system, structure, or component in accordance with a graded approach based on factors such as (a) level of risk, (b) age, status, and condition of a facility or process, (c) history of problems at a site or facility, (d) adequacy of existing safety documentation, and (e) complexity of products or services involved as required by 10 CFR Part 830.120. Engineering and quality control personnel review and approve the design to ensure acceptance of the design process and to ensure that the appropriate level of detail for the design is being applied. The adequacy of a design is generally verified through design reviews, alternate calculations, or qualification testing.

Documents used to implement design changes (such as design drawings, specifications, facility change forms, and work releases) are controlled as discussed in Section 14.5. Essential design information is assembled and placed in a project file or engineering design file. Computer software is controlled as necessary to satisfy the requirements or specifications for reliability, verification, maintainability, and continuity of operation.

\subsubsection{Procurement}

Requisitioners of material and services (including radioactive sources, radioactive material, and radiation-generating devices) are responsible for preparing a requisition in accordance with the EG\&G Idaho Company Procedures Manual, Section 3.1, "Preparation of Outside Requisition," to ensure that the requirements are clearly specified. 10 CFR 830.120 and DOE Order 5700.6C provide the requirements for requisition of quality-level items and services.

Review and approval of requisitions for materials or services are conducted according to Section 9.9, "Quality Engineering Reviews," and Section 10.18, "Radioactive Source Handling and Control," of the EG\&G Idaho Company Procedures Manual. Revisions to procurement documents, excluding editorial clarifications, receive the same level of review and approval as the original document.

Procurement services coordinate any contract changes at the direction of the requestor. Supplier data attending requisitions are maintained with procurement services; however, copies of supplier data can be obtained on request. Suppliers who furnish Quality Level 1 and Quality Level 2 items and services are evaluated and selected using the process described in the EG\&G Idaho Company Procedures Manual, Section 3.8, "Supplier Evaluation."

Inspection instructions, sufficiently detailed to ensure that the source or receiving inspection will accurately verify product conformance to specified requirements, are prepared in accordance with the Company Procedures Manual, Section 9.15, "Procurement Product Acceptance Inspection Instructions." When Quality Level 1 and Quality Level 2 commercial-grade items are procured, they are managed in accordance with Section 3.5, "Equivalency Evaluation of Commercial Grade Items," or Section 3.7, "Dedication Process for Commercial Grade Items," of the Company 
Procedures Manual, as applicable. A nonconformance report is used to report and control items that do not satisfy specified acceptance criteria.

\subsubsection{Inspection and Testing for Acceptance}

Inspections for acceptance of items and activities are performed by qualified personnel independent of those performing the activity being inspected. Qualification and certification of quality inspection personnel are conducted per the EG\&G Idaho Company Procedures Manual, Section 1.10, "Personnel Certification for Nondestructive Examination," and Section 1.14, "Certification of Inspection and Test Personnel." When required, inspection plans are prepared and followed that specify the (a) characteristics to be inspected, (b) personnel authorized to perform inspections, (c) inspection sequence (if important), (d) methods to be employed, (e) acceptance criteria, and (f) documentation of inspection results.

Also, personnel needed to perform or verify acceptance inspections and tests to satisfy code, standard, or other technical requirements for measuring and test equipment are qualified and certified in accordance with the requirements of 10 CFR 830.120 and DOE Order 5700.6C. Furthermore, personnel using measuring and test equipment should report any abnormalities to management.

Quality inspection records comply with requirements of 10 CFR 830.120 and DOE Order 5700.6C.

\subsubsection{Assessments}

ER management regularly assesses the adequacy of the quality assurance program and ensures its effective implementation. Instructions for conducting self-assessment surveillances are provided in the EG\&G Idaho Company Procedures Manual, Section 1.7, "Self-Assessment Program." The manager is responsible for:

- Developing the surveillance plan and target lists, and for determining the status of and updating the surveillance plan

- Providing training to personnel, as necessary, to conduct effective surveillances

- Ensuring that root causes are identified for all findings, that lessons learned are disseminated, and that priorities are established

- Ensuring that the department manager is apprised of the major findings, strengths, weaknesses, and proposed corrective actions and their completion

- Maintaining records in accordance with DOE Order 1324.5B.

In accordance with 10 CFR 830.120 or DOE Order 5700.6C, ER is periodically audited by trained personnel. The independent performance assessment (IPA) group of CRC satisfies this requirement. This group is responsible for conducting independent performance and compliance assessments and audits for LITCO in the environmental, safety, health, and quality areas. IPA 
evaluates facilities and programs to ensure compliance with laws, regulations, orders, guidances, and company policy, as well as to improve overall performance by the use of best management practices and trending of performance information. The group is functionally located within the Quality Assurance and Oversight branch of CRC and reports to the Performance Oversight Department in the Quality Assurance and Oversight branch of LITCO. The audits are conducted using commonly accepted auditing techniques. The ER manager, or a designated alternate, is responsible for ensuring that the findings of an audit report are evaluated and that the scope and root causes or risk prioritization of any problems identified are determined as follows:

- The manager assigns actions that will correct any deficiencies identified and prevent their recurrence

- The manager provides a written corrective action response for each audit finding.

Independent assessments are performed by the Quality Systems and Services and the Performance Oversight Departments of the Quality Assurance and Oversight Branch of the Presidents' Office. 


\subsection{References}

U.S. Department of Defense, (DOD 1988), "Calibration Systems Requirements," MII-STD45662A, August 1, 1988. 


\section{EMERGENCY PREPAREDNESS}

Emergency preparedness for the Idaho National Engineering Laboratory (INEL) environmental restoration (ER) program and Decontamination and Dismantlement (D\&D) activities is part of the INEL emergency management program. This chapter describes how ER/D\&D activities are integrated into the existing INEL program.

\subsection{Introduction}

U.S. Department of Energy (DOE) policy is to operate facilities and activities in a responsible manner, preventing and effectively mitigating emergencies should they occur, thereby assuring the safety and health of workers, the public, and the environment. These responsibilities include maintaining emergency preparedness and response capabilities, establishing public and interagency communications, identifying emergency events, performing appropriate notifications, and implementing mitigating actions, including protective actions.

In compliance with federal regulations, DOE directives, and Emergency Management Guides, the DOE Idaho Operations Office (DOE-ID) prepared the DOE-ID INEL/West Valley Demonstration Project Emergency Preparedness Plan (DOE-ID 1993). The plan provides sitespecific direction for DOE and contractors to respond to emergencies at the INEL. The DOE-ID plan provides overall coordination between DOE contractor emergency plans and procedures and directs the response of DOE field elements.

Each DOE ER/D\&D contractor developed an emergency plan or policy for corporate response to an INEL emergency, delineating acceptable means to comply with DOE emergency preparedness requirements within the contractor's purview. In addition, emergency planning and preparedness for each area and major facility at the INEL is addressed by area emergency plans or facility emergency plans developed by the responsible DOE contractor. Emergency plans were prepared for Idaho Chemical Processing Plant (ICPP), Radioactive Waste Management Complex, Test Area North (TAN), Test Reactor Area (TRA), Waste Reduction Operations Complex/Waste Experimental Reduction Facility/Power Burst Facility (WROC/WERF/PBF), and the Central Facilities Area (CFA). The CFA INEL emergency plan addresses the CFA and all remaining areas of INEL not otherwise covered by specific area plans or facility plans. The facility or area emergency plan promulgated under DOE 5500 Series Orders controls all emergency response activities within its area of jurisdiction, including any tenant ER/D\&D activities.

Health and safety plans provide specific emergency response information for each ER/D\&D activity. The health and safety plan complies with the emergency response planning provisions of CFR 29 1910.120, "Hazardous Waste Operations and Emergency Response," or 29 CFR 1910.38, "Employee Emergency Plans and Fire Prevention Plans," and is consistent with the INEL facility and area-specific emergency plans, the contractors' emergency plans, and the DOE-ID INEL emergency plan (DOE-ID 1993). The health and safety plan contains instructions for minor emergencies and reportable occurrences, with reference to the INEL area or facility emergency plan applicable to a reportable occurrence or operational emergency at the ER/D\&D activity site. 


\subsection{Requirements}

The standards, regulations, and DOE orders applicable to this chapter are identified in Table 15-1. These requirements are implemented by Lockheed Idaho Technologies Company via its adoption of the EG\&G Idaho manuals and procedures.

\subsection{Scope of Emergency Preparedness}

The health and safety plan prepared in accordance with 29 CFR 1910.120 defines types of emergencies which could occur at the ER/D\&D site. These emergencies may include, but not be limited to, personnel occupational injury or illness within the exclusion (contaminated) zone, personnel occupational illness or injury in the support zone, fire or explosion, personal protective equipment failure, and hazardous or radioactive material spills or releases. If any of these occurrences are detected, emergency procedures are implemented.

\subsection{Emergency Preparedness Planning}

The following sections give an overview of the emergency plans written for the various areas at INEL. As stated before, ER/D\&D activity emergency plans consist of the health and safety plan, which addresses specific emergencies associated with the activity. The area emergency plans are followed as needed when working in the various areas.

\subsubsection{Emergency Response Organization}

DOE-ID administers the emergency response program at the INEL. Contractors provide day-to-day emergency response support at INEL facilities. The role of DOE-ID and contractor emergency response organizations (EROs) is to mitigate the consequences of an emergency. EROs provide initial and ongoing support and assistance to emergency response workers performing actions that involve direct mitigation of the emergency event. This section describes the INEL EROs and the roles of providing support and assistance during emergency response efforts. Also, interrelationships with Federal, state, tribal, and local organizations are addressed.

Five primary organizations (DOE-ID ERO, INEL ERO, CFA ERO, area ERO, and onscene incident command organization) provide direction for major emergency response functions. They also compose the team that has the decision-making authority to carry out emergency response. The primary organizations' responsibilities include the following:

- DOE-ID ERO. The DOE-ID ERO is structured so that DOE-ID can (a) fulfill its Federal emergency management oversight role and (b) allow the affected contractor's senior management to direct and oversee the originating facility emergency response. DOE-ID may relieve a contractor of command in accordance with the DOE contract or through authority specified in applicable DOE orders or federal regulations. 
Table 15-1. Applicable standards, regulations, and DOE orders.

\section{Standard, Regulation,} or DOE Order

29 CFR 1910.38

29 CFR 1910.120

40 CFR 300

40 CFR 302

40 CFR 355

DOE 5500.1B

DOE 5500.2B

DOE 5500.3A

DOE 5500.4A

DOE 5500.10

DOE 5000.3B
Title

Employee Emergency Plans and Fire Prevention Plans

Hazardous Waste Operations and Emergency Response

National Oil ancl Hazardous Substances Contingency Plan

Designation, Reportable Quantities, and Notification

Emergency Planning and Notification.

Emergency Management System

Emergency Categories, Classes, and Notification and Reporting

Planning and Preparedness for Operational Emergencies

Public Affairs Policy and Planning Requirements for Emergencies

Emergency Readiness Assurance Program

DOE Emergency Management Guides

Occurrence Reporting and Processing of Operations Information
Description

Requires that actions be taken to ensure employee safety from fire and other emergencies.

Establishes guidance for emergency response to releases of hazardous material.

Describes the National Contingency Plan for oil and hazardous substances

Establishes reportable quantities and notification requirements for releases

Establishes threshold planning quantities and planning requirements for coordination of offsite and onsite response.

Emphasizes the overall responsibilities of DOE Headquarters and DOE field personnel for emergency planning and response.

Describes the three categories of DOE emergencies: Operational, Energy, and Continuity of Government Emergencies.

Establishes requirements for planning and preparedness for Operational Emergencies.

Provides policies for communications between the public, DOE elements, contractors, and other authorities during an emergency.

Contains requirements of the emergency readiness assurance program for exercises, audits, and critiques.

Provides acceptable methods for meeting DOE 5500 Series Orders emergency planning requirements.

Establishes a system for reporting operations information, including Operational Emergencies and Reportable Occurrences, and tracking appropriate corrective actions to prevent recurrence. 
- INEL ERO. The INEL ERO is directed by a senior management official from an INEL contractor who is responsible for the facility, building, or program where the emergency originates. The senior official serves as emergency director at the INEL Emergency Operations Center (EOC) located in Idaho Falls, Idaho. The other senior management officials act as emergency support directors. The EOC is set up with an operations support director, a logistics support director, a planning support director, and a finance/legal support director; these personnel assist the emergency director in mitigating the incident.

- CFA ERO. The CFA ERO is responsible for classifying the event as an emergency, making initial protective action recommendations to affected populations, and taking appropriate measures to mitigate the emergency. Emergency response is directed from the CFA Emergency Control Center (ECC) under the direction of the CFA emergency action manager (EAM). The EAM is responsible for overall incident management until the EOC is declared operational. After EOC activation, the emergency director assumes strategic incident management and coordination of the event; however, the EAM retains tactical command of response activities at the site.

- Area ERO. The area ERO assists the CFA ERO in classifying the event, making initial protective action recommendations to affected populations, and taking appropriate measures to mitigate the emergency. Emergency response by the area ERO is directed from the area command post under the direction of the area emergency coordinator. The emergency coordinator is responsible for overall incident management until the ECC is declared operational. After ECC activation, the EAM assumes strategic incident management and coordination of the event, assisted by the area emergency coordinator.

- On-scene incident command organization. The first responder on the scene at the originating facility will be in charge at the scene until relieved by appropriate emergency response personnel. First responders may report immediately to the scene or to a predetermined staging area in accordance with response procedures and directions that depend on alarms and condition-specific instructions. First responders are only responsible for protecting people and assessing the emergency condition from a safe distance until assistance and additional response personnel arrive.

ER/D\&D incident command is initially established by the Field Supervisor or other onsite authority responsible for the ER/D\&D activity. The Field Supervisor implements the Occupational Safety and Health Administration safety and health plan for minor occurrences most likely to be encountered during ER/D\&D activities. - Depending on the nature of the emergency and the need for assistance, the field supervisor will obtain any additional assistance through the designated area or facility emergency coordinator. The area emergency coordinator will activate the facility or area ERO for a serious reportable occurrence or an operational emergency. Incident command probably will remain at the ER/D\&D site for any credible emergencies.

In initial stages, incident command will be established on-scene by the ER/D\&D field supervisor consistent with incident response team leaders. If the event requires 
activating the area or facility area command post; incident command will be transferred to the area emergency coordinator. A facility ERO is always in command of emergency response at the originating facility. Incident command will normally remain at the originating facility with the emergency coordinator.

Some emergencies, such as a catastrophic earthquake, could affect the entire INEL without originating at any specific facility. In such cases, each facility ERO will direct response within the respective facility. Overall emergency response command will be accomplished through the EOC. Each facility will coordinate actions with others through the EOC to the extent practicable. The DOE-ID Manager/Duty Officer will appoint an emergency director in the EOC in such emergencies.

The Baseline Safety Analysis File is written to cover ER/D\&D activities classified as Hazard Category 3 (those that pose a significant localized hazard) as defined in DOE Order 5480.23, "Nuclear Safety Analysis Report," April 30, 1992, or are less than Hazard Category 3. Therefore, emergency planning will not need to involve offsite organizations other than for notification. Offsite organizations are identified in the DOE-ID INEL Emergency Plan (DOE-ID 1993) and are not addressed in this chapter.

\subsubsection{Assessment Actions}

The purpose of a consequence assessment is to determine the possible effects that an emergency may have on onsite personnel, and on the public, facilities, and environment. Initial, short-term consequence assessments are conducted by the field supervisor. Overall, long-term consequence assessment activity during the course of an emergency is the responsibility of the INEL EOC. The consequence assessment can result in (a) classification of the event as an alert, site area emergency, or general emergency, and (b) initiation of a protective action. The consequence assessment identifies specific values, indicators, or characteristics of the event, such as alarms, field samples, dose levels, concentration levels, and observations.

Information on the status of the emergency will be provided by the field supervisor or the area command post throughout the emergency so that INEL EOC and CFA/INEL ECC can keep abreast of developments. During the course of the emergency, hazards associated with the emergency will be monitored and assessed continuously. This task will be accomplished by field monitoring teams, on-scene emergency response personnel, and hazard assessment personnel. Weather, dose estimates, and exposure estimates are tracked, evaluated, and updated as needed to provide current information that can be used to determine the dispersion effects of the accident, if necessary.

Emergency action levels and event classifications are contained in the area or facility emergency plan, assists in rapid recognition of accident indicators and the timely commitment of response resources. A system of preapproved decisions is developed by each facility to allow onsite supervisory personnel (for example, shift supervisors and duty officers) to make rapid decisions affecting personnel, facilities, and resources in response to an emergency. 


\subsubsection{Notifications}

The field supervisor is notified of any accidents, injuries, illnesses, or conditions potentially threatening to the ongoing safety of the activity. Upon site evacuation or any reportable occurrence, in accordance with DOE Order 5000.3B, the field supervisor promptly notifies the Warning Communications Center (WCC), explaining the nature of the occurrence, actions under way, and emergency response assistance needed, followed by notification of the area EAM. All occurrences related to safety and health and actions taken to aid personnel and mitigate the emergency are recorded in field logs.

The EAM will ensure that state, local, and tribal authorities receive notification within 15 min after an operational emergency is classified.

Upon notification by the WCC, DOE Headquarters will ensure that appropriate Federal emergency response agencies and organizations are notified, as necessary.

After the initial notification is complete, offsite agencies will be updated as new information becomes available or at intervals of no longer than $60 \mathrm{~min}$.

For an emergency that has been classified as an alert, site area emergency, or general emergency, the EAM may order the actuation of audible emergency warning sirens in the area. Siren-generated signals serve as the primary means for notifying personnel, visitors, and transients in the immediate area.

\subsubsection{Emergency Response Equipment and Facilities}

The following subsections describe the equipment and facilities that are maintained for emergency use.

15.4.4.1 Emergency Response Equipment. Emergency response equipment for ER/D\&D activities must provide for detection of potential hazards, protection of personnel, handling of contaminated or injured personnel, preservation of equipment and property, and protection of the local environment.

Detection devices are installed in work areas to detect and warn of workplace hazards in accordance with requirements for radiation monitoring or hazardous materials monitoring (Chapters 3,7, and 8). Explanatory signs or tags are posted immediately adjacent to the warning device to describe the hazardous condition. Procedures explain the action to be taken in response to warning devices. A summary of specific response actions is posted adjacent to moveable hazardous material or radiation monitors in remote locations.

Supplementary warning equipment to notify or signal site personnel of an evacuation is provided to ensure prompt and complete evacuation of affected areas. An evacuation plan map is kept at the site. The map indicates evacuation routes from the activity site to assembly areas and to emergency support facilities. 
At least one $20-\mathrm{lb}$ fire extinguisher is readily available and at hand during operations. Additional fire extinguishers may be required by the health and safety plan to ensure immediate availability for larger facilities.

Portable eyewash fountains and sufficient portable water for flushing are readily available for the duration of the task. The task industrial hygienist determines the number and location of portable eyewash stations.

The health and safety support staff evaluates the potential for radioactive material spills and, if appropriate, recommends placement of one or more contamination spill kits. These kits contain plastic bags, absorbent material, latex gloves and liners, plastic shoe covers with rubber overshoes, smear survey wipes and holding bags, pencils, grease pencils, and paper, radiological postings and labels, yellow rope, yellow plastic sheeting, and duct tape. The health and safety support staff may recommend staging additional spill mitigation supplies, if appropriate.

15.4.4.2 Emergency Response Facilities. There are four locations from which to operate and support an emergency response: from the originating facility, from site support facilities, from DOE facilities, and from state/local facilities. Two facilities, the originating facility $\mathrm{ECC}$ and facility control room, are operated by the originating facility contractor. The EOC, CFA ECC, WCC, Reception Center, Decontamination Center, Transportation Staging Areas, and Public Information Center are operated by the site support contractor. DOE-ID provides oversight to emergency response activities in the EOC. Decontamination activities in the Decontamination Centers are supervised by the originating facility contractor health physics and industrial hygiene personnel. Each offsite municipality operates a local EOC. In addition, most municipalities are served by a local dispatch center.

The following facilities have separate, stand-alone ECCs: the ICPP, TRA, Argonne National Laboratory-West (ANL-W), and Naval Reactors Facility (NRF). All other EOCs and ECCs, including the INEL EOC, are multi-purpose facilities; most are used for conference rooms.

The WCC is located in Room 92 of the DOE-ID Headquarters Building, Idaho Falls, Idaho. The WCC serves as the emergency notification and activation center for the INEL. The WCC is staffed continuously 365 days/yr and is responsible for facilitating notifications as requested by the on-scene commander EAM or the emergency director. The WCC maintains ERO duty rosters and activates the INEL EOC.

Several personnel and equipment decontamination centers are located at the DOE-ID INEL facilities. A list of decontamination facilities follows:

- TAN-Radiological showers in the Decontamination Room (TAN-633)

- TRA-Equipment decontamination facility (TRA-667)

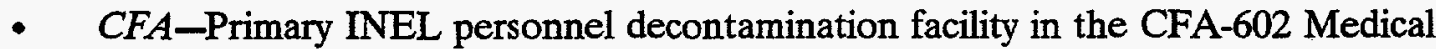
Building 
- WROC/WERF/PBF-Radiological decontamination showers in each of the change rooms in the PBF Reactor Building

- ICPP-ICPP Equipment Decontamination Facility (CPP-659).

Other INEL facilities establish temporary decontamination centers as the need arises.

The INEL Fire Department has three stations on the INEL site. The main station is located at CFA; TAN and ANL-W have substations. All three fire stations are staffed $24 \mathrm{hr} /$ day by career firefighters trained as emergency medical technicians. Each of the three stations has the equipment and expertise to respond to explosions, fires, spills, and medical emergencies. The INEL Fire Department maintains a specially equipped hazardous materials vehicle used in the event of hazardous chemical incidents. In addition, the seven-county area surrounding the INEL has 18 fire districts that operate a total of 30 fire stations staffed by 179 paid and 313 volunteer firefighters.

The INEL Fire Department provides ambulance service on the INEL site. In addition, medical dispensaries located on the site provide assessment and treatment for ill or injured personnel within site boundaries. The CFA dispensary is staffed by a physician and nurses; the other dispensaries are staffed by nurses and a visiting physician who rotates among the dispensaries.

Ambulance services in the region are provided by some of the county governments and the cities of Blackfoot, Dubois, Idaho Falls, and Pocatello fire departments. Residents in Butte County receive ambulance service from a private ambulance company, the Lost River Ambulance Service. In addition to ambulance service, the seven-county area is served by four quick response units, two medical helicopters, and one clinic specializing in emergency medical services.

Eight hospitals serve the seven-county region. No hospitals are located in Clark or Jefferson counties. The Eastern Idaho Regional Medical Center in Idaho Falls is the largest hospital in the region with 311 beds. Lost Rivers District Hospital in Butte County has only four licensed beds.

The Willow Creek Building (WCB) medical facility, located at WCB S-1, is available for medical administrative activities including preparation and dispensing of necessary medications such as potassium iodide. WCB may be activated nights and weekends at the direction of the medical director.

The medical facilities at ANL-W, ICPP, NRF, TRA, and TAN have limited emergency medical capability and ordinarily would not be available in a facility evacuation.

\subsubsection{Protective Actions}

The following protective actions are conducted under the facility or area emergency plan and the activity-specific health and safety plan, as coordinated through the interface agreement. If an ER/D\&D emergency affects both ER/D\&D and non-ER/D\&D personnel, the facility or area emergency plan will be activated and the protective actions will be implemented by the EAM. Conversely, ER/D\&D personnel will respond to activation of the area or facility plan during a 
non-ER/D\&D emergency as required. In any case, offsite protective actions, such as public evacuations, are not expected as a result of ER/D\&D emergencies.

Any life-threatening emergency such as a significant fire, explosion, or hazardous release, initiates an ER/D\&D site personnel evacuation using the shortest possible route, without regard for decontamination, personnel contamination, or surface contamination spread. Decontamination activities are addressed after personnel are safe from injury. In the event of a fire or explosion, all personnel not essential to controlling the situation are evacuated from the ER/D\&D site and fire and/or explosives experts are notified. The field supervisor is responsible for ensuring that appropriate evacuation procedures are followed in the event of an ER/D\&D emergency.

In the event of an occupational injury or illness in the exclusion (contaminated) zone, personnel must take necessary immediate actions in accordance with procedures and staff training. The field supervisor assesses the situation and activates emergency response procedures in consultation with the health and safety support staff. If work is halted at the site because of an injury, operational personnel do not reenter the exclusion zone for routine operations until the cause of the injury or illness is identified and corrected.

Injuries or illnesses incurred in the support zone are addressed as in the exclusion zone. Routine operations may resume when the cause of the injury or illness is identified and corrected, or if the field supervisor and health and safety support staff conclude that the cause of the illness or injury will not affect continued performance.

A contaminated, injured worker is accompanied by at least one worker, preferably an industrial hygienist or radiation protection worker, to inform medical personnel of the level of decontamination performed before leaving the work area and to provide specific details about the illness or injury.

Any worker experiencing personal protective equipment failure is instructed to leave the exclusion zone, accompanied by a workmate. The health and safety support staff evaluates the situation and determines if exposure to hazardous or radioactive materials occurred. Reentry will not be permitted until the equipment has been repaired or replaced.

If site equipment fails to operate properly, the field supervisor will be notified and will determine the effect of the failure on continued operations. If the failure affects safety of personnel or prevents completion of defined tasks, operations personnel leave the task site in a secure condition until the situation is evaluated and corrected.

If hazardous or radioactive material is spilled or released, personnel refer to the area emergency preparedness procedures for spills and report the spill to area personnel as directed. Spills of petroleum products, decontamination solutions, calibration materials, equipment fuels, and other hazardous liquids must be assessed. 


\subsubsection{Training and Exercises}

Fundamental training for emergency response consists of safety and health plan training in accordance with 29 CFR 1910.120(e). Visitors not required to be familiar with the activityspecific health and safety plan shall be briefed on site emergency procedures and escorted.

ER/D\&D management ensures that all personnel are briefed on emergency equipment, the nature of safety warning devices in their area, and appropriate responses. Emergency communications protocols and responsibilities are explained prior to work. Management ensures that workers are familiar with evacuation procedures, evacuation routes, and the nature and location of the emergency response facilities.

ER/D\&D management must conduct an annual exercise to evaluate personnel performance. All communications during such drills are prefaced and followed by a statement clearly identifying the situation as a drill. Each drill or any actual emergency or reportable occurrence is followed by a critique and any deficiencies identified in the emergency plan are corrected.

In addition to ER/D\&D-specific training for emergency response, ER/D\&D personnel are trained to respond to the facility or area emergency plan for the ER/D\&D site. The DOE contractor responsible for the facility or area will assure that ER/D\&D personnel are trained, in accordance with the interface agreement. The training includes general employee response to area or facility emergencies, with additional training for ER/D\&D supervision on the interface between the ER/D\&D staff and the facility or area ERO.

\subsubsection{Recovery and Reentry}

Following any evacuation of the site because of health and safety-related issues, hazards are reassessed by the health and safety support staff and the cause of the hazard is corrected. The health and safety plan, work plan, operating procedures, operational safety requirements, and emergency plans shall be reviewed for adequacy and site personnel shall be briefed on any changes prior to resuming operations.

Team personnel reentering the evacuated zone to assess conditions shall use the same level of personal protective equipment as prior to evacuation, or protective equipment Class $\mathrm{C}$, whichever is more restrictive. Class $\mathrm{A}$ or $\mathrm{B}$ protective equipment may be prescribed by health and safety personnel, as appropriate. 


\subsection{References}

Department of Energy (DOE 1993), Emergency Management Guides, DOE, Washington, D.C.

Department of Energy Idaho Operations Office (DOE-ID 1993), U.S. Department of Energy INEL and West Valley Demonstration Project Emergency Plan, DOE-ID, Idaho Falls, ID. 


\section{PROVISIONS FOR DECONTAMINATION AND DECOMMISSIONING}

\subsection{Introduction}

This chapter provides guidance for preparation of Chapter 16 of a facility-specific safety analysis report. The provisions for Decontamination and Dismantlement (D\&D) in this chapter are only applicable for new facilities or for significant modifications to existing facilities required for environmental restoration activities. According to DOE-STD-3009-94, for "Hazard Category 3 facilities, a minimal description of the provisions is expected."

\subsection{Requirements}

The following Codes of Federal Regulations, U.S. Department of Energy (DOE) orders, and other requirements are applicable to this chapter. These requirements are implemented by Idaho National Engineering Laboratory manuals and procedures as indicated throughout this chapter.

- $\quad 10$ CFR 830.120, "Nuclear Safety Management, Quality Assurance"

- DOE-STD-3009-94, "Preparation Guide for U.S. Department of Energy Nonreactor Nuclear Facility Safety Analysis Reports," July 1994

- DOE-EM-STD-5502-94, "Hazard Baseline Documentation," August 1994

- DOE Order 5400.5, "Radiation Protection of the Public and the Environment," February 8, 1990

- $\quad$ DOE Order 5700.6C, "Quality Assurance," August 21, 1991

- $\quad$ DOE Order 5820.2A, "Radioactive Waste Management," September 1988

- DOE Order 6430.1A, "General Design Criteria," April 6, 1989.

\subsection{Description of Conceptual Plans}

This chapter briefly summarizes the major features of the programmatic commitment to the safety basis. For facilities whose mission is D\&D (Buckland 1993) and are radiological facilities according to DOE-EM-STD-5502-94, an auditable safety analysis is required that addresses the safety aspects of the D\&D activities.

\subsubsection{Minimizing Site and Environmental Contamination}

Facilities in which radioactive or other hazardous materials are used are designed and operated to simplify D\&D and increase the potential for reuse. Applicable and appropriate design features and operating procedures that simplify and facilitate D\&D, based on relevant 
decommissioning methods and potential reuse, will be identified during the planning and design phase.

Requirements for D\&D methods contained in DOE Order 6430.1A, Section 1300-11, shall be followed. Requirements are summarized in the following discussion.

16.3.1.1 Decontamination. Design of the areas in a facility that may become contaminated with radioactive or other hazardous materials under normal or abnormal operating conditions should incorporate measures to simplify future decontamination. Such items as service piping, conduits, and ductwork are kept to a minimum in these areas and are arranged to facilitate decontamination. Filters are positioned in ventilation systems in locations that minimize contamination of ductwork. Walls, ceilings, and floors are finished with washable or strippable coverings commensurate with anticipated process fluids and decontamination techniques to be used in the facility. In some areas, metal liners are required. If necessary, all cracks, crevices, and joints are caulked or sealed and finished smoothly to prevent contaminated material accumulation in inaccessible areas. Underlying goals are to minimize construction and decontamination costs and waste.

16.3.1.2 Decommissioning. The following design principles are considered for facilities handling radioactive and hazardous materials:

- Use of modular, separable confinements for radioactive and other hazardous materials to preclude contamination of fixed portions of the structure

- Use of localized liquid transfer systems to avoid long runs of buried contaminated piping, emphasis on localized batch solidification of liquid waste, and special provisions in design to ensure integrity of joints in buried pipelines

- Location of exhaust filtration components of the ventilation systems at or near individual enclosures to minimize long runs of internally contaminated ductwork

- Use of equipment, including effluent decontamination equipment that prevents as much as possible accumulation of radioactive or other hazardous materials in relatively inaccessible areas including curves and turns in piping and ductwork, and use of accessible, removable inspection covers to allow visual inspection

- Selection of easily decontaminated materials to reduce the amount of radioactive and hazardous materials requiring disposal

- Selection of designs that ease cut-up, dismantlement, removal, and packaging of contaminated equipment from the facility (for example, removal and dismantlement of air filtration equipment, large tanks, vessels, equipment, and ductwork)

- Use of modular radiation shielding in place of monolithic shielding walls

- Use of lifting lugs on large tanks and equipment 
- Use of fully drainable piping systems that carry contaminated or potentially contaminated liquids.

In addition to the above requirements for D\&D in DOE Order 6430.1A, the following design considerations are applicable, based on previous D\&D experiences:

- Design of equipment such as hoods, pumps, and ventilation ducting to minimum volume specifications for ease of decontamination and reduction of contaminated volume of resulting waste:

- Incorporation into new facilities of collection tanks for diversion of liquid waste so that tank contents can be analyzed prior to discharge

- Consideration of purchasing or designing equipment that can be easily decontaminated

- Use of process equipment made of materials that will not interact chemically with the hazardous or radioactive materials

- Choice of materials to minimize decontamination costs and resulting waste.

Operating procedures ensure that under normal operating conditions, contamination is contained in the expected locations. Furthermore, operating procedures facilitate prevention of accidents and define mitigative actions to be taken to reduce the potential spread of contamination from an accidental event. Procedures are developed, reviewed, and approved as discussed in Chapter 12.

\subsubsection{Recordkeeping of Operations}

Operational records are maintained for contaminated facilities for use in the future preparation of D\&D plans. Operational records include facility design drawings and modifications, data on contamination levels, prior decontamination activities, and incident reports required by DOE directives. Recordkeeping requirements include the following information:

- Identification of all radioactive and hazardous materials

- Identification of areas of facility or site contaminated as well as type and quantity of radioactive and hazardous material

- Inventory of contaminated equipment and systems.

\subsubsection{Site Restoration Plans}

Facilities constructed and operated to support Environmental Restoration Program activities are decontaminated to acceptable levels, as applicable, for reuse, recycling, or disposal and removal. Typical facilities include the following:

- Temporary or portable personnel and equipment decontamination facilities 
- Temporary or portable process facilities, such as groundwater treatment, and soil washing

- Temporary radioactive or hazardous waste storage buildings

- Access control facilities and fences

- Temporary office facilities.

Any site contamination resulting from the facility's operations is remediated in accordance with the requirements of DOE Order 5400.5, Chapter IV; the environmental remediation action Record of Decision; or other established standards commensurate with the proposed site use.

The policy and guidelines in DOE Order 5820.2A, Chapter V, for the decommissioning of radioactively contaminated facilities shall be followed, as applicable. These policies and guidelines describe radiological, chemical, and physical $\mathrm{D} \& \mathrm{D}$ processes. A decision analysis will be applied to select preferred D\&D alternative methods. Selection of preferred methods is followed by development of a detailed D\&D plan. 


\subsection{References}

R. J. Buckland, D. J. Kenoyer, D. H. Preussner, (Buckland 1993), INEL D\&D Long-Range Plan, EGG-WM-10924, EG\&G Idaho, Inc., October 1993. (Rev 10 to be published September 1995.)

Department of Energy, Idaho Operations Office, (DOE-ID 1994), INEL Reusable Property, Recyclable Material, and Waste Acceptance Criteria (RRWAC), Revision 3, 1995. 


\section{MANAGEMENT, ORGANIZATION, AND INSTITUTIONAL SAFETY PROVISIONS}

\subsection{Introduction}

This chapter describes management, organization, and institutional safety measures for the Idaho National Engineering Laboratory (INEL) environmental restoration (ER) activities. The operating contractor for ER is Lockheed Idaho Technologies Company (LITCO). Within the LITCO organization, ER is a directorate in the Environmental Operations branch. Functions such as technical training, occupational safety, environmental protection, radiological control, emergency preparedness, and quality assurance and oversight are matrixed to ER from the Office of the President branch. Program business management functions are provided by the Business Management branch. The remedial design/remedial action contractor is Parsons Engineering Science, Inc., which reports directly to the ER directorate manager. Training, records management, and independent audit and assessment functions are performed through subcontract by Coleman Research Corporation.

Management ensures that there is a high level of excellence with regard to health and safety programs. The following program practices are implemented to achieve this policy:

- First priority is given to the safety and health of the workers, and to the protection of the environment and public. Safety and health are not subordinate to cost or schedule considerations.

- Operations are conducted in compliance with applicable environmental, safety, and quality requirements of the U.S. Department of Energy (DOE) and Federal and state regulatory agencies.

- Activities are conducted in a manner that recognizes and controls workplace hazards.

\subsection{Requirements}

The following DOE orders are applicable to this chapter. These requirements are implemented by LITCO via its adaption of the EG\&G Idaho manuals and procedures as indicated throughout the chapter.

- $\quad 29$ CFR 1910.120, "Occupational Safety and Health Standards, Hazardous Waste Operations and Emergency Response Independent Safety Review"

- DOE-STD-1004-92, "Root Cause Analysis"

- DOE Order 1324.5B, "Records Management Program," January 12, 1995

- DOE Order 5000.3B, "Occurrence Reporting and Processing of Operations Information," January 19, 1993; Chg 1, July 2, 1993 
- DOE Order 5480.19, "Conduct of Operations Requirements for DOE Facilities," July 9, 1990; Chg 1, May 18, 1992

- DOE Order 5480.20A, "Personnel Selection, Qualification, and Training Requirements for DOE Nuclear Facilities," November 15, 1994

- DOE Order 5480.21, "Unreviewed Safety Questions," December 24, 1991

- DOE Order 5480.22, "Technical Safety Requirements," February 25, 1992; Chg 1, September 15, 1992

- DOE Order 5480.23, "Nuclear Safety Analysis Reports," April 30,1992; Chg 1, March 10, 1994

- DOE Order 5484.1, "Environmental Protection, Safety, and Health Protection Information Reporting Requirements," February 24, 1981; Chg 7, October 17, 1990

- DOE Order 5500.2B, "Emergency Categories, Classes, and Notification and Reporting Requirements," April 30, 1991; Chg 1, February 27, 1992

- $\quad$ DOE Order 5631.1C, "Safeguards and Security Awareness Program," May 4, 1994

- $\quad$ DOE Order 5700.6C, "Quality Assurance," August 21, 1991.

\subsection{Organizational Structure, Responsibilities, and Interfaces}

This section summarizes the organizational support within LITCO that has been established for safe ER operations and activities.

\subsubsection{Organizational Structure}

The organizational interfaces for ER are illustrated in Figure 17-1. Cognizant discipline support to assist in the day-to-day activities is provided by the Environment, Safety, and Health (ESH) and Quality Assurance and Oversight Directorates in the Office of the President branch of LITCO. Cognizant discipline support includes radiation safety, industrial safety, emergency preparedness, environmental engineering, and quality assurance. ER is also supported in the functions of training, performance of audits and assessments, and records management by Colemen Research Corporation (CRC) through subcontract with the INEL Institute Directorate and Quality Assurance and Oversight directorates in the Office of the President branch and the Information Resources Management directorate in the Business of Management branch of LITCO. Maintenance and craft services are provided from the LITCO Site Services branch. Parsons Engineering Science, Inc. is the INEL remedial design/remedial action (RD/RA) Contractor reporting directly to the ER directorate manager. Procedures and document control and independent safety review functions are provided by the Environmental Operations branch. Procedures and training are discussed in Chapter 12, emergency preparedness programs in Chapter 15, and document control functions, supplied within the Environmental Operations branch, in Section 17.4.2. 


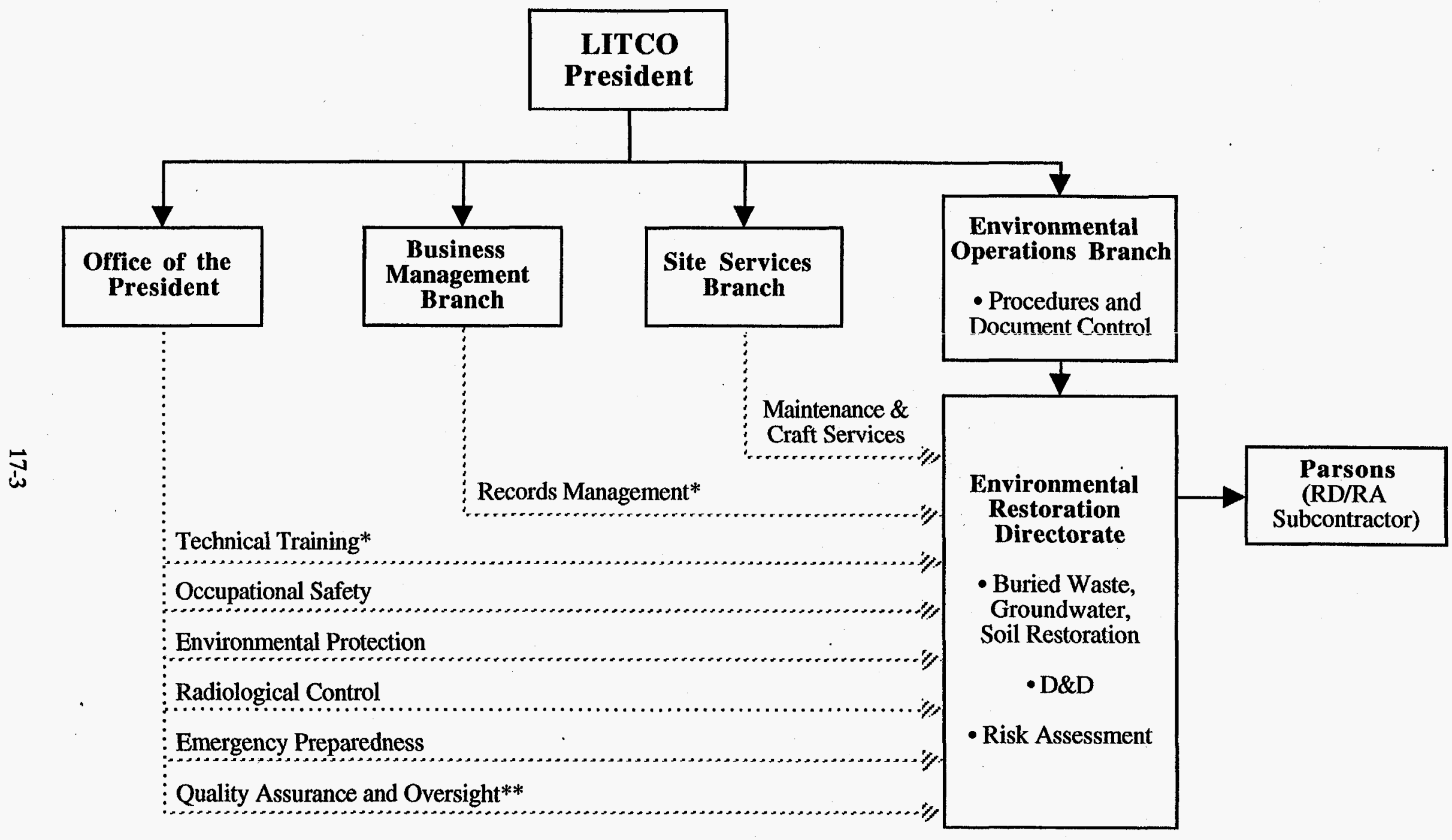

* Function performed by Coleman Research Corp (CRC)

** Audits and assessments performed by CRC

Figure 17-1. ER organizational interfaces. 


\subsubsection{Organizational Responsibilities}

As indicated in Figure 17-1, the ER directorate manager is responsible for and has full authority over all restoration and Decontamination and Dismantlement (D\&D) operations through the Buried Waste and Landfill Restoration, Groundwater Restoration, Soil Restoration, and Inactive Sites departments. The Chemical and Radiological Risk Assessment department provides safety analysis services, including unreviewed safety question (USQ) evaluations. The ER manager supports the department managers by providing the day-to-day supervisory authority and responsibility for conduct of operations. These managers are responsible for ensuring that activities are conducted safely in accordance with applicable procedures and requirements and for overseeing budget, maintenance, long-range planning, and staffing.

The ER directorate manager is currently supported by approximately 145 engineers, technicians, operations specialists, and project managers. These professionals are responsible for planning, performing day-to-day activities, and providing interface capabilities with the cognizant disciplines as needed for support services, such as utilities, safety audits, compliance, and maintenance, as indicated in Figure 17-1.

LITCO and Parsons managers have overall responsibility for assuring that activities are performed safely. These organizations are responsible for developing and implementing the following documentation for each activity:

- Health and Safety Plan

- $\quad$ ER or D\&D Plan

- $\quad$ Safety Analysis Report

- Quality Assurance Project Plan.

17.3.2.1 ER program Management. LITCO and Parsons are responsible for conducting day-to-day management and operation of INEL ER activities. The Project Management organization includes at a minimum the following elements: Project Manager with overall responsibility for safety and regulatory compliance and interface between the environmental remediation or D\&D project and technical support organizations and subcontractors; Field Supervisor with responsibility and authority to direct all field operations; Health and Safety Officer with responsibility and authority to develop and implement the Health and Safety Plan and verify compliance; and all other personnel necessary for activity-specific operations and emergency response.

The Health and Safety Plan establishes the specific chain of command and specifies the overall responsibilities of supervisors and employees.

17.3.2.2 ER program Technical Support. Technical support personnel are responsible for supervision and performance of technical support functions for ER activities. Expertise in areas including mechanical, electrical, instrumentation and control, chemistry, RD/RA technology, waste management, radiation and hazardous material protection, training, safety, quality assurance, 
document control, and emergency preparedness is normally provided as a technical support function. INEL-wide services and facilities include fire protection and onsite medical services.

17.3.2.3 Subcontractor Support. Subcontractors may be used to provide services including RD/RA support, technical support, and operations support. Subcontractor personnel are required to comply with the Health and Safety Plan for the ER activity. It is the responsibility of the Project Manager to assure that subcontractor personnel receive appropriate health and safety training as required by the Health and Safety Plan.

17.3.2.4 Administrative Controls. Administrative controls are established and implemented as summarized in the following sections.

17.3.2.4.1 Health and Safety Plan-An approved Health and Safety Plan provides necessary controls for safe and efficient operation. An approved.Health and Safety Plan will be in place for each ER activity. The elements of the plan are required by 29 CFR 1910.120. All personnel must comply with the requirements of the Health and Safety Plan during ER activities. A Health and Safety Officer is assigned to each activity to monitor and address issues concerning health and safety.

17.3.2.4.2 Personnel Training-Personnel are categorized relative to specific job function and receive training commensurate with this job function. A training program will be established for ER activities to train. personnel on facility and operating requirements and to assure suitable response by personnel to any abnormal occurrence. The training program is designed to stress safety consciousness and is described in Chapter 12.

17.3.2.4.3 Design and Procurement Controls-Design and procurement control is required to ensure that quality and safety requirements are satisfied. Controls provide for the following, as appropriate: source evaluation and selection, evaluation of objective evidence of quality furnished by the supplier, inspection and in-process audit at the source, audit and examination of items or services upon delivery or completion, or evaluation of item performance after installation.

\subsubsection{Staffing and Qualifications}

Staffing levels for all positions are based on the functions that require coverage and staffing levels required to provide that coverage. Staffing levels for normal day-to-day activities include a mix of management, administrative, maintenance, operations support, cognizant discipline, and engineering personnel.

17.3.3.1 Training. ER personnel are categorized relative to their specific job function and receive training commensurate with this job function. Based upon job and hazards analyses, training requirements are determined in accordance with DOE Order 5480.20A.

Training plans are prepared for: all personnel and are updated annually to reflect current requirements. The formal training requirements and program are designed to stress safety consciousness and are described in Chapter 12. Safety meetings, facility drills, and posted safety notices are also used to develop safety awareness. In addition to formal training, informal training 
is conducted through the required reading program, prejob briefings, and safety meetings. Both formal and informal training are documented and controlled to ensure that all affected personnel are included.

17.3.3.2 Monitoring Safety Performance. Managers are trained to assess the fitness of personnel for duty to prevent accidents or violations. All personnel are required to adhere to the LITCO drug-free workplace/substance abuse policy, which states that the company will not hire and may not retain employees who use, possess, or sell illegal substances or who abuse legal drugs. LITCO requires a pre-employment drug screen and implements subsequent testing of all employees based on random selection, reasonable suspicion, or accidents or incidents.

DOE Order $5631.1 \mathrm{C}$ establishes a security education program to ensure that personnel in distinctive positions meet the highest standards of reliability. Because of the relatively low hazard potential for operations covered by Baseline Safety Analysis File, the qualified and certified positions are not subject to the requirements of this order; however, minimum fitness for duty of the operators is assessed by the on-duty manager. The on-duty manager also assesses the relieving shift manager when multiple-shift operations are conducted. When operating on a single shift, the on-duty shift manager's fitness for duty is assessed by the ER manager or designated alternate.

\subsection{Safety Management Policies and Programs}

\subsubsection{Safety Review and Performance Assessment}

Safety issues are defined as noncompliances or inadequacies in the facility or facility processes, or as procedures that have the potential for injuring personnel or damaging the facility or environment. Safety issues are managed by conducting activities in a preventive mode that controls workplace hazards, by regular surveillance, audit, and appraisal of compliance to processes and procedures, and by tracking and dispositioning discrepancies in a manner commensurate with their severity. Such requirements are accomplished through the measures described below.

17.4.1.1 Self Assessments. Self-assessments are conducted in accordance with the EG\&G Idaho Company Procedures Manual, Section 1.7, "Self-Assessment Surveillances," which prescribes planning, targeting, and scheduling. The frequency of the self assessments is commensurate with the level of risk associated with the activities. Data generated from the selfassessment program are evaluated and disseminated through the Lessons Learned Program.

Self assessments provide feedback to senior management on effectiveness of line management implementation and oversight of environmental, safety, and health programs in satisfying DOE Directives and applicable regulations and requirements. The self-assessment program includes design, construction, and operational assessments which sample performance in the environmental, safety, and health arenas and gauge the adequacy of compliance. The INEL ER self-assessment program is periodically reviewed by management for adequacy of performance. 
17.4.1.2 Independent Assessments, Audits, and Reviews. The independent performance assessment (IPA) group of CRC is responsible for conducting performance and compliance assessments and audits for LITCO in the environmental, safety, health, and quality areas. IPA evaluates facilities and programs to ensure compliance with laws, regulations, orders, guidances, and company policy, as well as to improve overall performance by use of best management practices and trending of performance information. Chapter 14 provides additional discussion of quality assurance audits.

Approval of safety documents requires concurrence by independent safety reviewers as specified in the INEL Environmental Restoration Program Directives, PD 4.8, "Internal and Independent Review of Documents." Technical requirements are independently reviewed, with focus on compliance with applicable safety limits, technical requirements, and specifications; quality assurance/quality control; and applicable DOE, federal, state, and local requirements. Minimum review-level requirements for safety documents or safety issues are based on hazards present.

17.4.1.3 Safety Issue Discovery. Safety issues can be brought to the attention of management by any employee. For situations threatening safety, health, or the environment, all employees have the authority to immediately stop the activity. Specific requirements are in effect that require satisfactorily resolving the issue with the person stopping the work and obtaining manager's approval before work resumes.

17.4.1.4 Safety Issue Risk Determination and Analysis. Independent audit findings are prioritized as Category I, II, or III. Category I addresses a situation for which an imminent danger exists to human health or the environment. Category II addresses a significant risk or substantial deviation from a DOE order, code, standard or regulation; violation of a law, written agreement, or permit condition. The situation does not present a clear and present danger to human health or the environment. Category III findings address a deviation from a DOE order, code standard, or regulation, or address a need for an improvement in the margin of safety. For Category I and II findings, a corrective action plan is required that describes the corrective action and specifies an implementation date. A root-cause analysis or risk prioritization is performed in accordance with DOE-STD-1004-92, "Root Cause Analysis."

17.4.1.5 Safety Issue Tracking. Safety issue corrective action requirements are tracked and reported. Category I issue corrective actions are the highest priority and receive immediate resolution. Category II issues are significant and receive the second highest priority for resolution. Category III issues receive the lowest priority for resolution. Findings of noncompliance or inadequacies during surveillances, audits, appraisals, or self-assessments, or during routine operations that are classified as safety issues are reported and resolved in accordance with the appropriate procedures. All safety issues are documented in the Issues Management Evaluation Database, which identifies the deficiency and its category, identifies the responsible person, and tracks the required resolution date. Deficiencies found during surveillances, audits, and appraisals are evaluated against the criteria for occurrence reporting found in DOE Order 5000.3B, as implemented by the EG\&G Idaho Safety Manual, and are reported accordingly. 
17.4.1.6 Unreviewed Safety Questions. The USQ determination process, as required by DOE Order 5480.21, is implemented according to the EG\&G Idaho Company Procedures Manual, Section 7.3, "Unreviewed Safety Questions." The purpose of the USQ determination process is to ensure that issues with potential impact on the authorization basis are brought to the attention of DOE, and to provide the flexibility needed to conduct day-to-day operations.

\subsubsection{Configuration and Document Control}

The objectives of configuration and document control are to assure that records of activities are prepared and maintained to furnish objective, auditable evidence of safety and quality. To meet the objectives of the.configuration and documentation control, the requirements and responsibilities for records control are established and documented in accordance with DOE 1324.5B, and DOE 5700.6C.

Configuration control is the process of managing and controlling changes to baseline configuration items to ensure that changes are adequately defined, evaluated, reviewed, and approved. Changes to facility documentation, equipment, and safety documentation (Health and Safety Plans, Hazard Classifications, Safety Analysis, and Technical Safety Requirements) are documented in document revision requests, drawing revision requests, document change notices, and facility change forms. The USQ process interfaces with configuration management through these documents, which implement the requirement to perform a USQ determination as part of the change control process. All ER-generated documents (whether controlled or not) are processed through Administrative Record and Document Control. The Environmental Restoration Management Control Procedure, MCP-230, establishes policy and procedures to ensure compliance with requirements for issuing, distributing, controlling, and revising ER documentation.

\subsubsection{Occurrence Reporting}

Criteria to notify contractor management and DOE-ID of safety-related occurrences at ER sites and facilities are established by DOE 5000.3B. Detailed guidance is provided in the activityspecific Health and Safety Plan and the EG\&G Idaho Conduct of Operations Manual, which also establishes the responsibilities and requirements for notification, investigation, and reporting of accidents and abnormal occurrences. The Project Manager, Field Supervisor, and shift managers are trained in proper occurrence identification and notification procedures, and all personnel are trained to initiate immediate notification of any work-related occurrences to their supervisor.

An Occurrence Report will be prepared for all reportable occurrences. The Occurrence Reporting and Processing System (ORPS) is an operational data base used by DOE contractor and departmental elements to transmit, update, and approve occurrence reports required by DOE Order 5000.3B. ORPS provides the DOE community with a readily accessible data base that contains information about occurrences at DOE facilities, causes of those occurrences, and corrective actions.

Corrective actions are tracked by ESH branch personnel to ensure completion and closeout. 


\subsubsection{Safety Culture}

Administrative controls and procedures are implemented to instill a safety culture, a safety consciousness, and a questioning attitude among personnel. A critical element of safety implementation is the commitment to a safety culture. This attitude sets the tone for all activities, and has the clear support of all levels of management. Methods have been established and implemented to ensure that safety concerns are identified and resolved promptly and effectively. These methods include:

- Normal channels of comrnunication to the management of ESH professionals

- Company-sponsored ombudsman program

- $\quad$ ESH hotline

- Occupational safety and health complaints to the DOE Idaho Operations Office.

Specific programs or processes used to develop and implement this safety consciousness are described in this section.

17.4.4.1 Work Control. With the exception of routine activities (such as janitorial, administrative, and housekeeping), work is performed in accordance with reviewed and approved work control documents, and is scheduled and controlled by the manager. Operational controls have been defined and implemented to ensure safe and efficient operation in accordance with applicable DOE orders, and state and Federal requirements and guidelines. Federal regulations dictate the operational requirements, except where the State of Idaho has been granted primacy from the governing Federal agency. Applicable DOE, Federal, and state requirements are implemented by using EG\&G Idaho manuals, which are supplemented by the following work control documents:

- Detailed operating procedure. A step-by-step procedural document that requires sign-off verification at the completion of predetermined steps or sections. Used to control critical repetitive operations.

- Standard operating procedure. A step-by-step procedure that does not require verification of operation steps. Used for the conduct of routine operations where a specific record of activities is not required.

- Work order. Used to control crafts personnel performing corrective maintenance or facility modifications, and to perform nonroutine operations, nonroutine waste repackaging, waste handling, or decontamination work. A short form may be used for simple activities not requiring detailed instructions. A short form shall not be used for activities involving radioactive or hazardous materials, or for activities affecting quality.

- Preventive maintenance procedure. Used to perform routine and scheduled preventive maintenance activities on systems and components. 
- Safe work permit. Used to specify controls that have not been addressed in other work control documents for work to be performed where significant safety hazards are expected. Specifies personal protective equipment, safety procedures, and restrictions to be used during the conduct of work.

- Radiological work permit. Used to control nonroutine work and work in areas with changing radiological conditions.

17.4.4.2 Emergency Response and Monitoring Function. Emergency response information for each restoration or D\&D activity is provided by the Health and Safety Plan. This document defines the actions required for emergencies, such as personnel occupational injury or illness in the contaminated or support zone, fire or explosion, personal protective equipment failure, and hazardous or radioactive material spills or releases. These items are covered in training programs to facilitate appropriate responses to emergency situations. Chapter 15 provides a complete discussion of emergency preparedness.

17.4.4.3 Conduct of Operations. All operations and maintenance activities are conducted in a disciplined manner using established procedures and program directives, and in accordance with the EG\&G Idaho Conduct of Operations Manual. Through implementation of this manual, operations are conducted in compliance with the requirements of DOE Order 5480.19. Specific information regarding the implementation of conduct of operations is provided in Chapter 11. 